Prepared in cooperation with DeKalb County Department of Watershed Management

\title{
Hydrology and Water Quality in 15 Watersheds in DeKalb County, Georgia, 2012-16
}

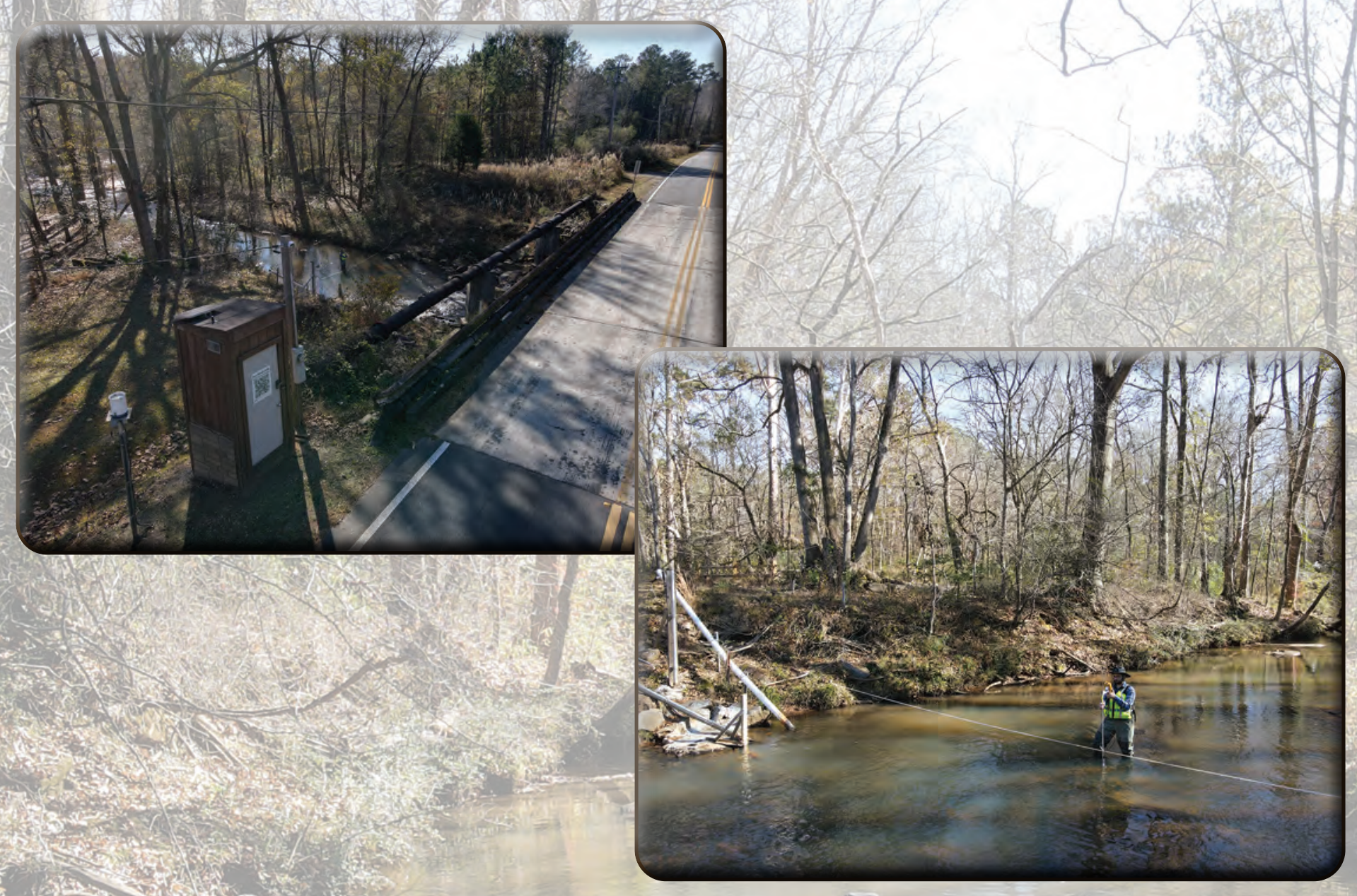

Scientific Investigations Report 2021-5126 
Cover: Photographs of Jarrod T. Henderson, U.S. Geological Survey (USGS), measuring discharge at Pole Bridge Creek at Evans Mill Road near Lithonia, Georgia, USGS site number 02204037, November 30, 2021. Photographs by Andrew E. Knaak, USGS. 


\section{Hydrology and Water Quality in 15 Watersheds in DeKalb County, Georgia, 2012-16}

By Brent T. Aulenbach, Katharine Kolb, John K. Joiner, and Andrew E. Knaak

Prepared in cooperation with DeKalb County Department of Watershed Management

Scientific Investigations Report 2021-5126 


\section{U.S. Geological Survey, Reston, Virginia: 2022}

For more information on the USGS - the Federal source for science about the Earth, its natural and living resources, natural hazards, and the environment—visit https://www.usgs.gov or call 1-888-ASK-USGS.

For an overview of USGS information products, including maps, imagery, and publications, visit https://store.usgs.gov/.

Any use of trade, firm, or product names is for descriptive purposes only and does not imply endorsement by the U.S. Government.

Although this information product, for the most part, is in the public domain, it also may contain copyrighted materials as noted in the text. Permission to reproduce copyrighted items must be secured from the copyright owner.

Suggested citation:

Aulenbach, B.T., Kolb, K., Joiner, J.K., and Knaak, A.E., 2022, Hydrology and water quality in 15 watersheds in DeKalb County, Georgia, 2012-16: U.S. Geological Survey Scientific Investigations Report 2021-5126, 105 p., https://doi.org/ 10.3133/sir20215126.

Associated data for this publication:

Aulenbach, B.T., Knaak, A.E., and Joiner, J.K., 2021, Streamwater constituent load data, models, and estimates for 15 watersheds in DeKalb County, Georgia, 2012-2016: U.S. Geological Survey data release, https://doi.org/10.5066/ P9M6WCRH.

U.S. Geological Survey, 2019, USGS water data for the Nation: U.S. Geological Survey National Water Information System database, https://doi.org/10.5066/F7P55KJN.

ISSN 2328-031X (print)

ISSN 2328-0328 (online

ISBN 978-1-4113-4430-3 


\section{Acknowledgments}

The authors wish to thank personnel of DeKalb County Department of Watershed Management for their long-term commitment to improved data and understanding of water quality in the watersheds in their county. This report is possible because of the field data-collection efforts and analysis expertise of the U.S. Geological Survey (USGS), South Atlantic Water Science Center Data Section personnel. Thanks also go to USGS employees Aaron Porter, Alana Spaetzel, Daniel Calhoun, and Kimberly Waltenbaugh for their thoughtful reviews and Jeffrey Corbett for his illustration work that much improved this report. 



\section{Contents}

Acknowledgments ……...................................................................................................................

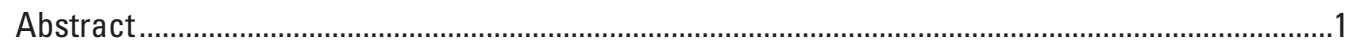

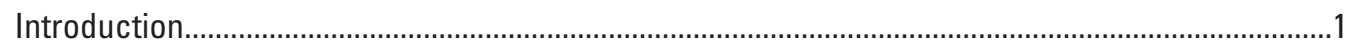

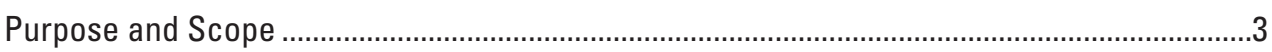

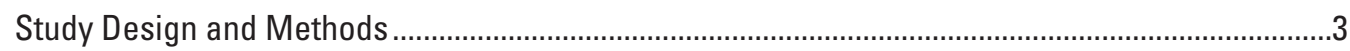

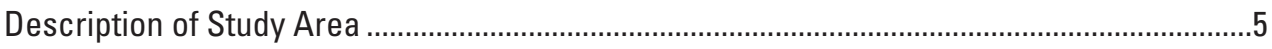

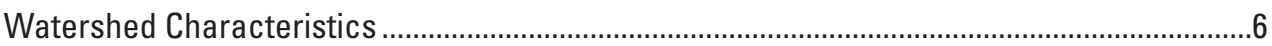

Surface-Water Monitoring .....................................................................................................

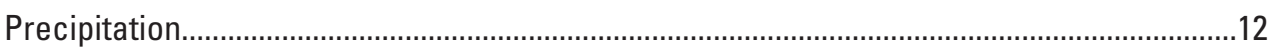

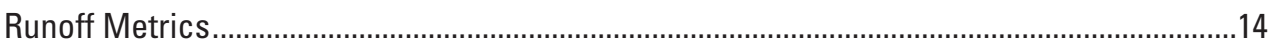

Stream-Water Constituent Load Estimation ..........................................................................14

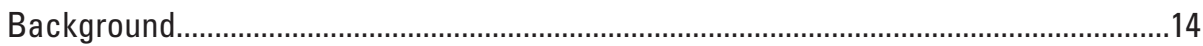

Regression-Model Load Estimation Methods .................................................................14

Regression-Model Load Uncertainty Estimates ..............................................................18

Beale Ratio Estimator Methods...............................................................................19

Escherichia coli Bacteria Modeling .................................................................................19

Watershed Relations Among Watershed Characteristics, Runoff Metrics, and Yields..........20

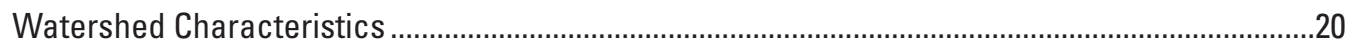

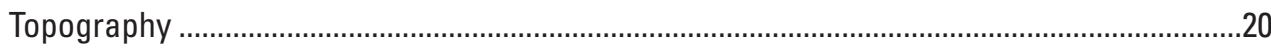

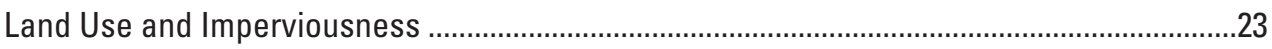

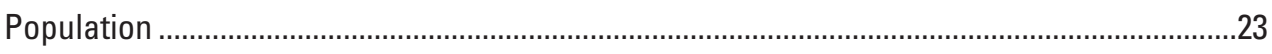

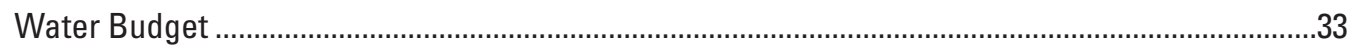

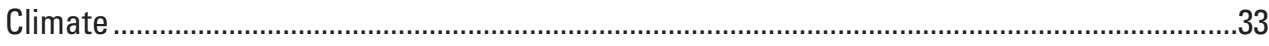

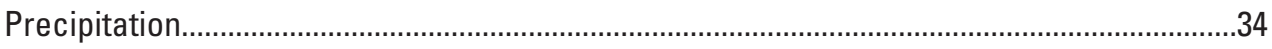

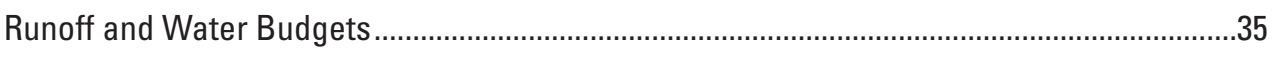

Relations Between Runoff Metrics and Watershed Characteristics.........................................41

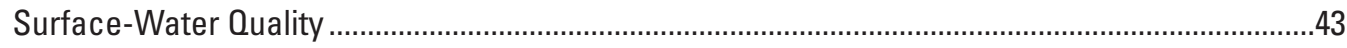

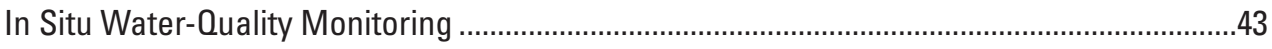

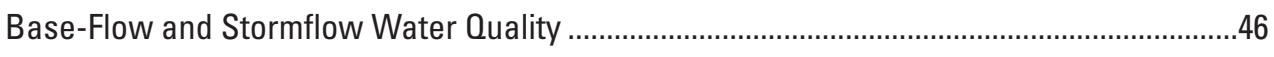

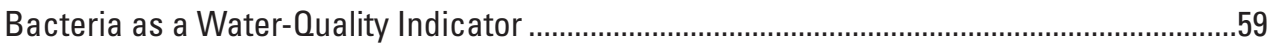

Escherichia coli Modeling ........................................................................................6

Constituent Loads and Yields...........................................................................................

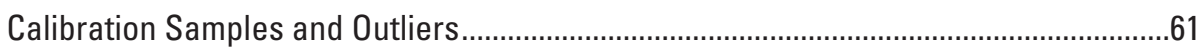

Load Modeling.....................................................................................................61

Annual Loads for Study Watersheds .........................................................................65

Watershed Constituent Yields ....................................................................................

Correlations in Watershed Constituent Yields .............................................................76

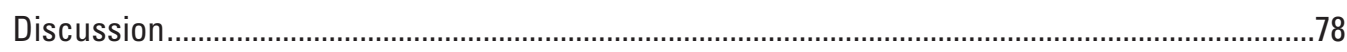

Relations Among Watershed Characteristics, Runoff Metrics, and Constituent Yields.........78

Comparison to Nearby Watershed Study ......................................................................... 80

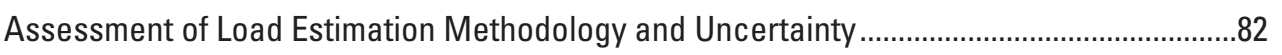

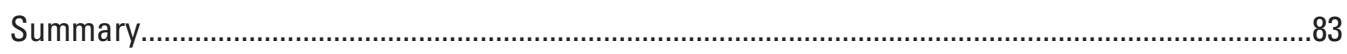

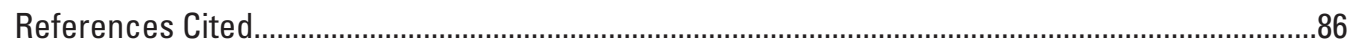


Appendix 1. Water-Quality Assurance and Control Summary ....................................................95

Appendix 2. Regression-Model Load Estimation Methodology Changes.....................................98

Appendix 3. LOADEST Load Model Evaluation....................................................................99

Appendix 4. Assessment of Effects of Time-Step Load Methodology on Load Estimates.........103

\section{Figures}

1. Map showing location of the study area and the 15 monitored watersheds and U.S. Geological Survey streamflow, water-quality, and precipitation monitoring sites, DeKalb County, Georgia

2. Photograph showing multiparameter stream monitoring site, Little Stone Mountain Creek, DeKalb County, Georgia, August 2017 ..................................................5

3. Map showing land-surface elevation for DeKalb County, Georgia.................................22

4. Map showing land-surface slope for DeKalb County, Georgia ......................................24

5. Graph showing average land-surface slope for the 15 monitored watersheds in DeKalb County, Georgia ..................................................................................................25

6. Graphs showing percentage of each land use group within each of the 15 monitored watersheds, the watersheds study area, and DeKalb County, Georgia ........27

7. Graph showing percent developed imperviousness within the 15 monitored watersheds in DeKalb County, Georgia, 2015

8. Map showing population density for the area of the 15 monitored watersheds and DeKalb County, Georgia, 2015

9. Graph showing population density of the 15 monitored watersheds in DeKalb County, Georgia, 2015

10. Graph showing weekly drought severity in DeKalb County, Georgia, for years 2011-17 as a percentage of county area.

11. Graph showing annual precipitation totals for $\mathbf{1 5}$ monitored watersheds in DeKalb County, Georgia, 2012-16.

12. Graph showing monthly average precipitation for 15 monitored watersheds in DeKalb County, Georgia, 2014-16.

13. Graph showing annual runoff for 15 monitored watersheds in DeKalb County, Georgia, 2012-16, and the annual average runoff for 2014-16

14. Graph showing monthly average runoff for 15 monitored watersheds in DeKalb County, Georgia, 2014-16.

15. Graph showing annual runoff ratio for 15 monitored watersheds in DeKalb County, Georgia, 2012-16.

16. Graph showing monthly average runoff ratio for 15 monitored watersheds in DeKalb County, Georgia, 2014-16.

17. Graph showing annual stormflow runoff for $\mathbf{1 5}$ monitored watersheds in DeKalb County, Georgia, 2012-16.

18. Graph showing annual base-flow index for 15 monitored watersheds in DeKalb County, Georgia, 2012-16.

19. Graph showing monthly average base-flow runoff and stormflow runoff and the base-flow index for the area of the monitored watersheds in DeKalb County, Georgia, 2014-16. 
20. Scatterplots showing base-flow index (BFI) versus percent developed imperviousness, base-flow runoff versus percent developed imperviousness, and BFI versus base-flow runoff for 15 watersheds in DeKalb County,

Georgia, 2014-16.

21. Scatterplots showing average annual runoff, runoff ratio, and average annual stormflow runoff versus percent developed imperviousness for 15 watersheds in DeKalb County, Georgia, 2014-16

22. Scatterplots showing runoff ratio versus base-flow index for 2014 to 2016, 2014, 2015, and 2016 for 15 watersheds in DeKalb County, Georgia.

23. Graphs showing streamflow and in situ water-quality monitoring data from the North Fork Peachtree Creek site showing seasonal variations for 2015: daily mean streamflow and median turbidity, daily mean temperature and mean specific conductance, and daily mean dissolved oxygen and median $\mathrm{pH}$

24. Graphs showing streamflow and in situ water-quality monitoring data from the North Fork Peachtree Creek site showing diurnal variations, May 13-15, 2015: streamflow and turbidity, temperature and specific conductance, and dissolved oxygen and $\mathrm{pH}$

25. Graphs showing streamflow and in situ water-quality monitoring data from the North Fork Peachtree Creek site showing response to a storm on 0 ctober 3 , 2015: streamflow and turbidity, temperature and specific conductance, and dissolved oxygen and $\mathrm{pH}$.

26. Boxplots showing base-flow and stormflow sample concentration magnitudes at 15 monitored watersheds in DeKalb County, Georgia, 2012-17: sonde specific conductance, biochemical oxygen demand, chemical oxygen demand, sonde $\mathrm{pH}$, laboratory turbidity, total suspended solids, suspended-sediment concentration, total nitrogen, total nitrate plus nitrite, total ammonia plus organic nitrogen, dissolved ammonia, total phosphorus, dissolved phosphorus, total organic carbon, total calcium, total magnesium, total cadmium, dissolved cadmium, total copper, total lead, total zinc, and total dissolved solids

27. Boxplots showing Escherichia coli and fecal coliform densities at 15 monitored sites in DeKalb County, Georgia, 2012-17.

28. Boxplots showing annual runoff and annual loads of biochemical and chemical oxygen demand, suspended sediment, nitrogen, phosphorus, total organic carbon, total calcium and magnesium, trace metals, and total dissolved solids for 15 monitored watersheds in DeKalb County, Georgia, 2014-16.

29. Boxplots showing annual average concentrations of biochemical and chemical oxygen demand, suspended sediment, nitrogen, phosphorus, total organic carbon, total calcium and magnesium, trace metals, and total dissolved solids for the 15 monitored watersheds in DeKalb County, Georgia, 2014-16.

30. Boxplots showing annual yields of biochemical and chemical oxygen demand, suspended sediment, nitrogen, phosphorus, total organic carbon, total calcium and magnesium, trace metals, and total dissolved solids for 15 monitored watersheds in DeKalb County, Georgia, 2014-16

31. Scatterplots showing base-flow index and runoff ratio versus impervious area for the 15 monitored watersheds in DeKalb County, Georgia, and 13 monitored watersheds in Gwinnett County, Georgia....

32. Boxplots showing average watershed yields for the 15 monitored watersheds in DeKalb County, Georgia, 2014-15, and 13 monitored watersheds in Gwinnett County, Georgia for October 2013 through September 2015 


\section{Tables}

1. Fifteen U.S. Geological Survey (USGS) water-quantity and water-quality monitoring sites included in the USGS-DeKalb County long-term

monitoring program

2. Summary of the land use classification system in this study

3. Dates when streamflow monitoring and water-quality sampling were established at the 15 U.S. Geological Survey (USGS) sites included in the USGS-DeKalb County long-term monitoring program.

4. Water-quality constituents measured and analyzed for samples collected in streams in Dekalb County, Georgia, units of measure, and predominant laboratory reporting limits.

5. Summary of analytical methods used to quantify water-quality constituent concentrations of samples in streams in DeKalb County, Georgia

6. U.S. Geological Survey precipitation monitoring sites included in the study, including dates monitoring was established

7. Watershed characteristics for 15 watersheds in DeKalb County, Georgia

8. Land use groups in the study watersheds for 2012, average percent developed imperviousness for 2011, and correlations between watershed land use group fractional area and imperviousness.

9. Land use group percentages in 15 watersheds in DeKalb County, Georgia, 2012 .........26

10. Percent developed imperviousness within the 15 monitored watersheds in DeKalb County, Georgia, 2011

11. Correlation coefficients between watershed characteristics and runoff metrics for 15 monitored watersheds in DeKalb County, Georgia, 2014-16

12. Escherichia coli model statistics and parameter coefficients for 15 monitored sites in DeKalb County, Georgia

13. Percentage of time Escherichia coli (E. coli) was predicted to be above the Beach Action Value at the 15 monitored sites in DeKalb County for the 3-year period 2014-16. Includes percentage of time when the E. coli model with turbidity explanatory variable(s) were used and percentage of 3-year period represented by model predictions.

14. Number of samples used for calibrating load regression models by constituent for 15 monitored watersheds in DeKalb County, Georgia. Includes number and percentage of outliers removed and censored samples

15. Summary of LOADEST model statistics and parameter by constituent and model type for 15 monitored watersheds in DeKalb County, Georgia .....

16. Summary of load estimation computational time steps, the frequency of turbidity data availability including the portion of runoff and load representation, the occurrence of stormflow conditions, the frequency of daily streamflow substitutions, and the frequency of streamflow exceedance of their calibration dataset maximum streamflow at the 15 monitored watersheds in DeKalb County for their respective 3- to 5-year periods of load estimates.

17. Annual constituent loads, precipitation, and runoff for the study watersheds in DeKalb County, Georgia, 2014-16.

18. Correlation coefficients between constituent yields and runoff for the 15 study watersheds in DeKalb County, Georgia, 2014-16. 


\section{Conversion Factors}

U.S. customary units to International System of Units

\begin{tabular}{|c|c|c|}
\hline Multiply & By & To obtain \\
\hline \multicolumn{3}{|c|}{ Length } \\
\hline inch (in.) & 2.54 & centimeter $(\mathrm{cm})$ \\
\hline inch (in.) & 25.4 & millimeter $(\mathrm{mm})$ \\
\hline foot $(\mathrm{ft})$ & 0.3048 & meter $(\mathrm{m})$ \\
\hline mile (mi) & 1.609 & kilometer $(\mathrm{km})$ \\
\hline \multicolumn{3}{|c|}{ Area } \\
\hline acre & 0.4047 & hectare (ha) \\
\hline acre & 0.004047 & square kilometer $\left(\mathrm{km}^{2}\right)$ \\
\hline square mile $\left(\mathrm{mi}^{2}\right)$ & 259.0 & hectare (ha) \\
\hline square mile $\left(\mathrm{mi}^{2}\right)$ & 2.590 & square kilometer $\left(\mathrm{km}^{2}\right)$ \\
\hline \multicolumn{3}{|c|}{ Flow rate } \\
\hline foot per second ( $\mathrm{ft} / \mathrm{s})$ & 0.3048 & meter per second $(\mathrm{m} / \mathrm{s})$ \\
\hline cubic foot per second $\left(\mathrm{ft}^{3} / \mathrm{s}\right)$ & 0.02832 & cubic meter per second $\left(\mathrm{m}^{3} / \mathrm{s}\right)$ \\
\hline million gallons per day $(\mathrm{Mgal} / \mathrm{d})$ & 0.04381 & cubic meter per second $\left(\mathrm{m}^{3} / \mathrm{s}\right)$ \\
\hline inch per hour (in/h) & 0.0254 & meter per hour $(\mathrm{m} / \mathrm{h})$ \\
\hline inch per year (in/yr) & 25.4 & millimeter per year $(\mathrm{mm} / \mathrm{yr})$ \\
\hline \multicolumn{3}{|c|}{ Mass } \\
\hline pound, avoirdupois (lb) & 0.4536 & kilogram (kg) \\
\hline \multicolumn{3}{|c|}{ Application rate } \\
\hline pound per acre per year ([1b/acre]/yr) & 1.121 & kilogram per hectare per year $([\mathrm{kg} / \mathrm{ha}] / \mathrm{yr})$ \\
\hline
\end{tabular}

International System of Units to U.S. customary units

\begin{tabular}{llll}
\hline \multicolumn{1}{c}{ Multiply } & By & To obtain \\
\hline millimeter (mm) & \multicolumn{1}{c}{ Length } & & \\
meter $(\mathrm{m})$ & 0.03937 & inch (in.) & \\
kilometer $(\mathrm{km})$ & 3.281 & foot (ft) & \\
\hline \multicolumn{3}{c}{ Volume } & \\
\hline liter $(\mathrm{L})$ & 0.6214 & mile (mi) & \\
\hline
\end{tabular}

Temperature in degrees Celsius $\left({ }^{\circ} \mathrm{C}\right)$ may be converted to degrees Fahrenheit $\left({ }^{\circ} \mathrm{F}\right)$ as follows:

${ }^{\circ} \mathrm{F}=\left(1.8 \times{ }^{\circ} \mathrm{C}\right)+32$.

Temperature in degrees Fahrenheit $\left({ }^{\circ} \mathrm{F}\right)$ may be converted to degrees Celsius $\left({ }^{\circ} \mathrm{C}\right)$ as follows: ${ }^{\circ} \mathrm{C}=\left({ }^{\circ} \mathrm{F}-32\right) / 1.8$. 


\section{Datum}

Vertical coordinate information is referenced to the North American Vertical Datum of 1988 (NAVD 88).

Horizontal coordinate information is referenced to the North American Datum of 1983 (NAD 83).

Elevation, as used in this report, refers to distance above the vertical datum.

\section{Supplemental Information}

Specific conductance is given in microsiemens per centimeter at 25 degrees Celsius $(\mu \mathrm{S} / \mathrm{cm}$ at $\left.25^{\circ} \mathrm{C}\right)$.

Concentrations of chemical constituents in water are given in either milligrams per liter (mg/L) or micrograms per liter ( $\mu \mathrm{g} / \mathrm{L})$.

Densities of bacteria in water are given in either counts per 100 milliliters (counts/100 mL), colony forming units per 100 milliliters (cfu/100 mL), or most probable number per 100 milliliters (MPN/100 mL).

A water year is the period from 0ctober 1 to September 30 and is designated by the year in which the period ends. 


\section{Abbreviations}

\begin{tabular}{|c|c|}
\hline 3DEP & 3D Elevation Program \\
\hline AICc & Corrected Akaike Information Criteria \\
\hline AMLE & adjusted maximum likelihood estimate \\
\hline BAV & U.S. Environmental Protection Agency's Beach Action Value \\
\hline $\mathrm{BFI}$ & base-flow index \\
\hline BIC & Bayesian Information Criteria \\
\hline BMPs & best management practices \\
\hline BOD & biochemical oxygen demand \\
\hline BRE & Beale ratio estimator \\
\hline $\mathrm{Ca}$ & total calcium \\
\hline $\mathrm{CaCO}_{3}$ & calcium carbonate \\
\hline $\mathrm{COD}$ & chemical oxygen demand \\
\hline cSO & combined sewer overflow \\
\hline $\mathrm{DCd}$ & dissolved cadmium \\
\hline $\mathrm{DO}$ & dissolved oxygen \\
\hline $\mathrm{DOC}$ & dissolved organic carbon \\
\hline $\mathrm{DP}$ & dissolved phosphorus \\
\hline E. coli & Escherichia coli \\
\hline EPA & U.S. Environmental Protection Agency \\
\hline EWI & Equal-width increment \\
\hline FIB & fecal indicator bacteria \\
\hline FNU & Formazin Nephelometric Units \\
\hline LOADEST & USGS Load Estimator software \\
\hline LRL & laboratory reporting limit \\
\hline $\mathrm{Mg}$ & total magnesium \\
\hline $\mathrm{NH}_{3}$ & dissolved ammonia \\
\hline NLCD & National Land Cover Database \\
\hline $\mathrm{NO}_{3}+\mathrm{NO}_{2}$ & total nitrate plus nitrite \\
\hline NWIS & National Water Information System \\
\hline OLS & ordinary least squares \\
\hline$p$-value & probability value \\
\hline PMRW & Panola Mountain Research Watershed \\
\hline$r$ & Pearson product-moment correlation coefficient \\
\hline$R^{2}$ & coefficient of determination \\
\hline
\end{tabular}




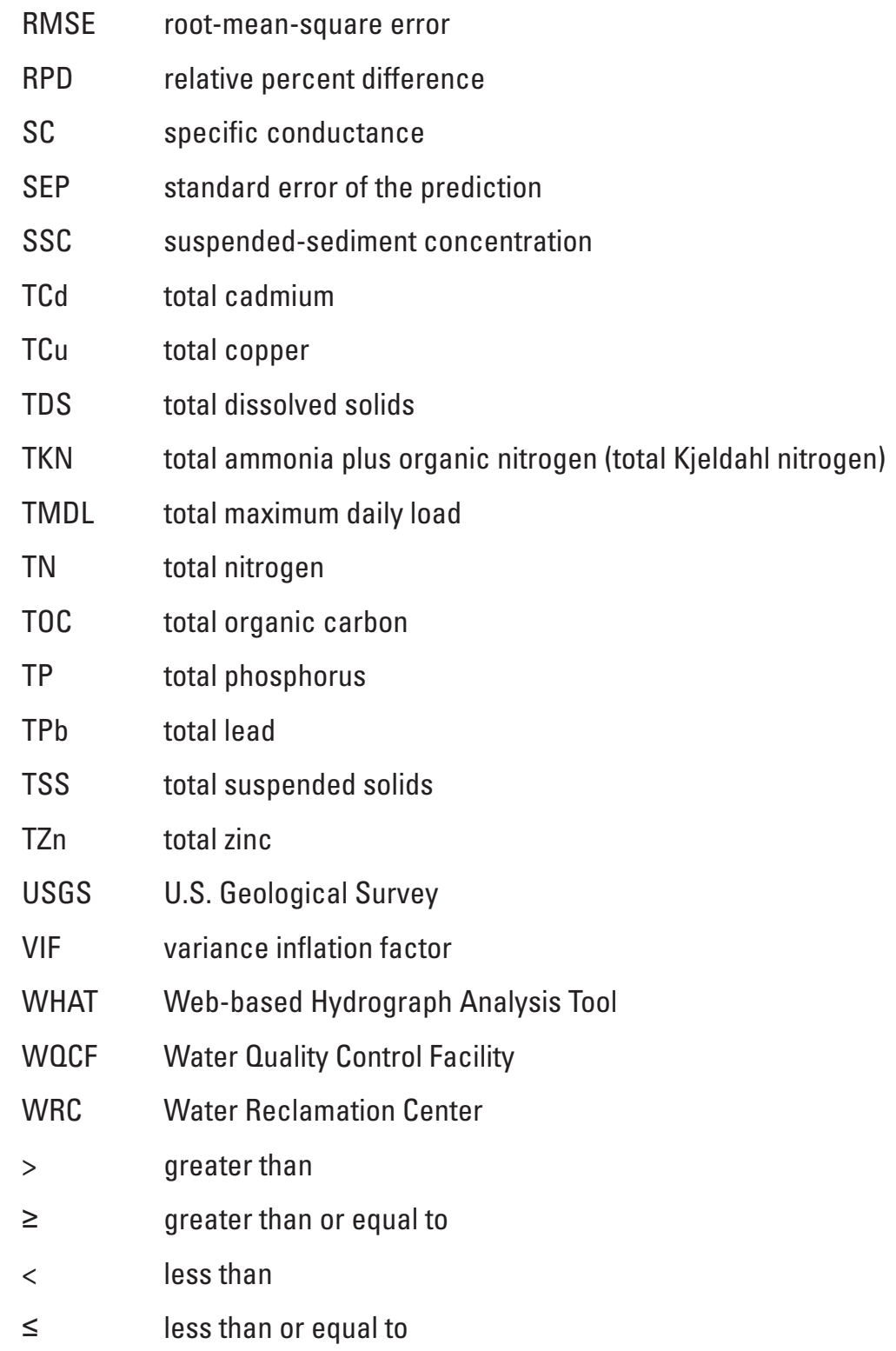




\title{
Hydrology and Water Quality in 15 Watersheds in DeKalb County, Georgia, 2012-16
}

\author{
By Brent T. Aulenbach, Katharine Kolb, John K. Joiner, and Andrew E. Knaak
}

\section{Abstract}

The U.S. Geological Survey, in cooperation with DeKalb County Department of Watershed Management, established a long-term water-quantity and water-quality monitoring program in 2012 to monitor and analyze the hydrologic and water-quality conditions of 15 watersheds in DeKalb County, Georgia - an urban and suburban area located in north-central Georgia that includes the easternmost part of the City of Atlanta. This report synthesizes the watershed characteristics and monitoring data collected for the first 5 years of the program, 2012 through 2016 . The study area was predominantly medium-density residential (43.9 percent), commercial/ industrial/institutional (21.4 percent), forest/park/agriculture (13.6 percent), and high-density residential (11.5 percent) land uses. Land-surface slope averaged 8.7 percent, imperviousness averaged 25.3 percent, and population density averaged 2,936 people per square mile. Watershed imperviousness ranged from 8.7 to 36.6 percent.

In the study area for 2014 to 2016 (when streamflow data were available for all watersheds), runoff represented 40.9 percent of precipitation. Hydrograph separations indicated that 43 percent of runoff occurred as base flow, whereas the remainder occurred as stormflow. Higher watershed imperviousness was significantly related to higher amounts of runoff (Pearson product-moment correlation coefficient $[r]$ $=0.517)$, higher runoff ratios $(r=0.646)$, and lower amounts $(r=-0.637)$ and proportions $(r=-0.898)$ of base-flow runoff. Stormwater best management practices have been implemented in the study watersheds; however, these practices do not appear to fully mitigate the effects of urban development and land use on stream hydrology.

Total copper, lead, and zinc concentrations in base-flow and stormflow samples exceeded the national recommended aquatic life criteria for chronic and acute conditions, respectively, to varying degrees. Escherichia coli density predictive regression models indicated that the U.S. Environmental Protection Agency's Beach Action Value was exceeded at individual watersheds between 44.6 and 100 percent of the time. Exceedance of the Beach Action Value indicates possible unsafe conditions for primary contact recreation and could be used for timely notification of the potential health risks. Annual loads and yields were estimated for 15 constituents.
Loads were typically higher for years with higher runoff while variations among watershed yields appear associated with watershed and land use characteristics. The lowest yields for almost all constituents occurred in the Stone Mountain Creek watershed-likely the result of the retention of sediment and reduction of nutrients in Stone Mountain Lake and two smaller downstream reservoirs within the watershed. The Little Stone Mountain Creek watershed also had some of the lowest yields for most constituents, likely due to the lack of many pollutant sources associated with its predominantly medium-density residential land use (95.5 percent), but had the highest total nitrate plus nitrite yields. The Intrenchment Creek watershed consistently had some of the highest yields across all constituents except for total nitrate plus nitrite. The high yields may be related to its high percentage of impervious area (36.0 percent) and high amount of heavily developed land use (high-density residential, 29.9 percent and commercial/industrial/institutional, 26.0 percent). Mean watershed constituent yields in this study were significantly higher than those from a similar analysis of 13 suburban to urban watersheds in adjacent Gwinnett County for 6 of the 10 constituents compared.

This study provides a thorough assessment of watershed characteristics, hydrology, and water-quality conditions of the 15 study watersheds and can be used to identify possible factors that affect runoff and water quality. Watershed managers can use these data and analyses to inform management decisions regarding the designated uses of streams, minimization of flooding, protection of aquatic habitats, and optimization of the effectiveness of best management practices.

\section{Introduction}

In watershed studies, stream-water quantity and quality, when measured at the outlet of a basin, serve as an integrated measure of the effects of all inputs and processes within the watershed (Semkin and others, 1994; Likens, 2001). Stream runoff is controlled by weather and climate; drainage characteristics such as density, network configuration, channel morphology, and land-surface slopes (Liu and others, 2006); subsurface characteristics such as soil and aquifer types, depths, geometry, and hydraulic conductivities; vegetative cover (Leopold, 1968); and land use. Outflowing stream-water 
quality reflects the cumulative effects of the complex interactions of multiple inputs, processes, and activities within the watershed, both spatially and temporally (MacDonald, 2000). These sources, processes, and activities include atmospheric inputs of precipitation and dry deposition (Smith and Alexander, 1983), inputs of point and nonpoint source pollutants, changes in land use, uptake of nutrients in plants (Reid and Hayes, 2003), and biogeochemical processes within the unsaturated and saturated zones. Biogeochemical processes include weathering (Maher, 2010, 2011), adsorption (Wood, 1978; Nodvin and others, 1986), cation exchange (Lai and Jurinak, 1972, Valocchi and others, 1981), nitrification (Smith and others, 2006), denitrification (Vogel and others, 1981; Rivett and others, 2008), and phosphorus mineralization (Mackey and Paytan, 2009). Reliable, temporal measures of constituent loads are necessary to determine whether water quality is improving or degrading, which can be used to assess the effects of changes in climate, land use, and point and nonpoint source pollutants on water quality and to evaluate the effectiveness of watershed-based mitigation strategies, such as best management practices (BMPs). In the United States, stream reaches that do not meet water-quality criteria for their designated use (U.S. Environmental Protection Agency [EPA], 2000a) are subject to waste-load allocation schemes that are based on the total maximum daily load (TMDL). A TMDL is defined as the maximum amount of a pollutant that a water body can receive and still meet its water-quality criteria (EPA, 2000b).

Urbanization, particularly the associated increases in impervious area, has been shown to have a great effect on rainfall-runoff relations (Leopold, 1968; Hollis, 1975; Ogden and others, 2011) and stream-water quality (Schueler, 1994; Schueler and others, 2009). Impervious areas include buildings and transportation infrastructure such as roads, parking lots, and sidewalks. Some of the more important effects of increased impervious area on hydrology (Jacobson, 2011) include (1) increased storm runoff and flood flows (Leopold, 1968), (2) increased storm flashiness, with higher peak stormflow responses with a shorter duration (Seaburn, 1969; Graf, 1977) and a decreased lag time between precipitation and peak streamflow (Espey and others, 1966), (3) increased recurrence interval of floods, particularly for smaller floods (Hollis, 1975; Konrad, 2003), and (4) decreased rainfall infiltration and groundwater recharge rates that result in lower stream base flow (Simmons and Reynolds, 1982; Rose and Peters, 2001). Many studies have also shown that urbanization's effects on the flow regime may decrease stream biological richness (for example, Gregory and Calhoun, 2007; DeGasperi and others, 2009; Richards and others, 2010) and that native stream biota are best adapted to natural, unaffected streamflows (Poff and others, 1997; Richter and others, 1996, 1998). More frequent and higher magnitude flooding can also increase erosion and transport of land-surface and stream sediments (Trimble, 1997) and associated pollutants, as well as altering streamchannel stability. Stormwater BMPs, also known as stormwater management controls, are used to reduce and mitigate the effects of urban development and land use on stream hydrology and water quality. The effectiveness of BMPs has been assessed in many studies, and BMPs have been shown to decrease flood peak streamflows (for example, Soong and others, 2009; Gebert and others, 2012; Hopkins and others, 2020), decrease sediment and nutrient loads (for example, Park and others, 1994; Inamdar and others, 2001), and increase infiltration (for example, Ku and others, 1992).

The effects of urbanization on stream runoff and water quality have been extensively studied in the Atlanta, Georgia, metropolitan area and throughout the Piedmont Physiographic Province in the southeastern United States. A study of streamflow trends in eight watersheds in the Atlanta metropolitan area over a 20 -year period indicated that streamflow flashiness and the frequencies of high-flow days increased in watersheds that had the largest increases in development, while watersheds that were already substantially developed had declining streamflow (Diem and others, 2018). In a study of flash flooding in nine urban watersheds in the Atlanta area, data indicated that flood response was dependent on a combination of basin size, drainage network characteristics, the spatial distribution of land use, and water storage in soils and stormwater detention ponds (Wright and others, 2012). An analysis of the influence of urban development patterns on streamflow in the Charlanta Megaregion (area from Charlotte, North Carolina, to Atlanta) indicated that higher occurrences of both high and low flows were associated with watersheds with higher percentages of impervious areas within their riparian buffers and those with greater contiguously developed open space land cover (Debbage and Shepherd, 2018). This study also suggested that the frequency of high flows in watersheds increased with the amount of impervious areas clustered in source areas. Rose and Peters (2001) found that groundwater levels in two urban wells in Atlanta had notable declines over the period 1958-1996 relative to non-urban wells in the area, with declines attributed to decreased groundwater recharge in urban watersheds.

Long-term water-quality monitoring data for the City of Atlanta indicated that elevated concentrations of chloride and trace metals likely resulted from chlorinated combined sewer overflows, deicing salts, and wash off from impervious surfaces (Peters, 2009). Stream-water loads estimated for this network indicated that at least 90 percent of suspendedsediment loads and loads of sediment-related constituents occurred during stormflow conditions (Horowitz, 2009). From a study of 12 small urban watersheds in Gwinnett County, $\mathrm{Ga}$. (within the Atlanta metropolitan area), Joiner and others (2014) similarly found that most of the annual suspendedsediment load was transported by the few largest storms of the year. Horowitz (2009) indicated that estimating loads on a daily time step for the small flashy watersheds in Atlanta resulted in substantial underestimates and that greater accuracy required time steps as short as $2-3$ hours. Flashy streams exhibit a quick and rapid increase in streamflow in response to precipitation and a rapid return to base-flow conditions and are characteristic of basins with steep slopes or extensive 
impervious areas. A study to determine the physical, chemical, and biological responses of streams to urbanization from 30 wadeable streams near Atlanta indicated that specific conductance (SC), chloride, sulfate, and pesticides increased with urbanization, and that algal, invertebrate, and fish communities exhibited statistically significant changes with urbanization (Gregory and Calhoun, 2007). A study of the effects of urbanization on macroinvertebrates in Piedmont streams in Georgia indicated that urbanization negatively affected macroinvertebrate biomass and community structure (Sterling and others, 2016). The U.S. Geological Survey (USGS) Southeastern Stream Quality Assessment of 76 wadeable streams in the urbanized Piedmont Ecoregion of the Southeastern United States indicated that urban streams were nitrogen-nutrient enriched, but total phosphorus concentrations in Atlanta streams were lower than concentrations in streams in reference watersheds (Journey and others, 2018).

Intensive, long-term monitoring of streamflow and water quality combined with the characterization of watersheds are essential to quantifying the effects of land use, point-source and nonpoint-source discharges, and management practices on surface water (water quantity, flow characteristics, and water quality). In 2012, the USGS, in cooperation with DeKalb County Department of Watershed Management, established a comprehensive long-term monitoring program of 15 watersheds in which consistent, high-quality water-quantity and water-quality data were collected to determine the status and trends in both stream runoff and water quality. In addition, these data were related to watershed characteristics to better understand factors that affect runoff and water quality. Watershed managers can use these data and analyses to inform management decisions related to maintaining the designated uses of streams, minimizing flooding, protecting aquatic habitats, and optimizing the effectiveness of BMPs.

\section{Purpose and Scope}

The purpose of this report is to summarize and analyze watershed characteristics and hydrologic and water-quality data collected as part of the USGS-DeKalb County long-term monitoring program for 15 watersheds for 2012-16. The specific goals of this report are to

- Present watershed characteristics of study watersheds including topography, land-surface slopes, topographic wetness index, land use, impervious area, and population density;

- Report and discuss the hydrologic setting and water budgets for the study watersheds, including annual and monthly precipitation, runoff, and runoff ratios. Relate runoff characteristics to watershed characteristics and climatic conditions;

- Summarize water-quality data from base-flow and stormflow samples collected at the outlet of each study watershed, including field and laboratory SC, biochem- ical oxygen demand (BOD), chemical oxygen demand (COD), field and laboratory $\mathrm{pH}$, turbidity, total suspended solids (TSS), suspended-sediment concentration (SSC), total nitrogen (TN), total nitrate plus nitrite $\left(\mathrm{NO}_{3}+\mathrm{NO}_{2}\right)$, total ammonia plus organic nitrogen (TKN), dissolved ammonia $\left(\mathrm{NH}_{3}\right)$, total phosphorus (TP), dissolved phosphorus (DP), total organic carbon (TOC), total calcium $(\mathrm{Ca})$, total magnesium $(\mathrm{Mg})$, total cadmium (TCd), dissolved cadmium (DCd), total copper $(\mathrm{TCu})$, total lead $(\mathrm{TPb})$, total zinc (TZn), total dissolved solids (TDS), Escherichia coli (E. coli) bacteria, and fecal coliform bacteria, and relate these data to watershed characteristics;

- Provide annual load and yield estimates for 15 constituents (BOD, COD, TSS, SSC, TN, $\mathrm{NO}_{3}+\mathrm{NO}_{2}$, TP, DP, TOC, Ca, Mg, TCu, TPb, TZn, and TDS) for each study watershed and relate loads and yields to watershed characteristics and hydrologic conditions; and

- Present surrogate models for E. coli bacteria for each watershed that could be used to assess the health risks of water-based recreational activities in near real time.

\section{Study Design and Methods}

Fifteen watersheds were monitored as part of the USGSDeKalb County long-term monitoring program (fig. 1). Physiographic, climatic, and hydrologic settings, along with topographic and land use attributes, were used to characterize the watersheds. The watershed outlets were monitored for stage (water level), streamflow, and five continuous water-quality parameters at 15 -minute intervals. A typical multiparameter stream monitoring site is shown in figure 2. Precipitation was monitored at 33 locations throughout the study area, including at 13 of the 15 watershed outlets. Waterquality samples were collected seasonally during base-flow and stormflow events and were measured or analyzed for 24 water-quality constituents. Regression models were developed for 15 water-quality constituents and were used to estimate watershed annual stream-water loads and yields, and their confidence intervals. Surrogate regression models were developed for $E$. coli bacteria to determine the feasibility of predicting bacteria densities in near real time. The USGS-DeKalb County long-term monitoring program uses a monitoring approach and methodology similar to those used in Gwinnett County, $\mathrm{Ga}$., for the long-term monitoring program of 13 watersheds (Landers and others, 2007; Landers, 2013; Joiner and others, 2014; Aulenbach and others, 2017a). 


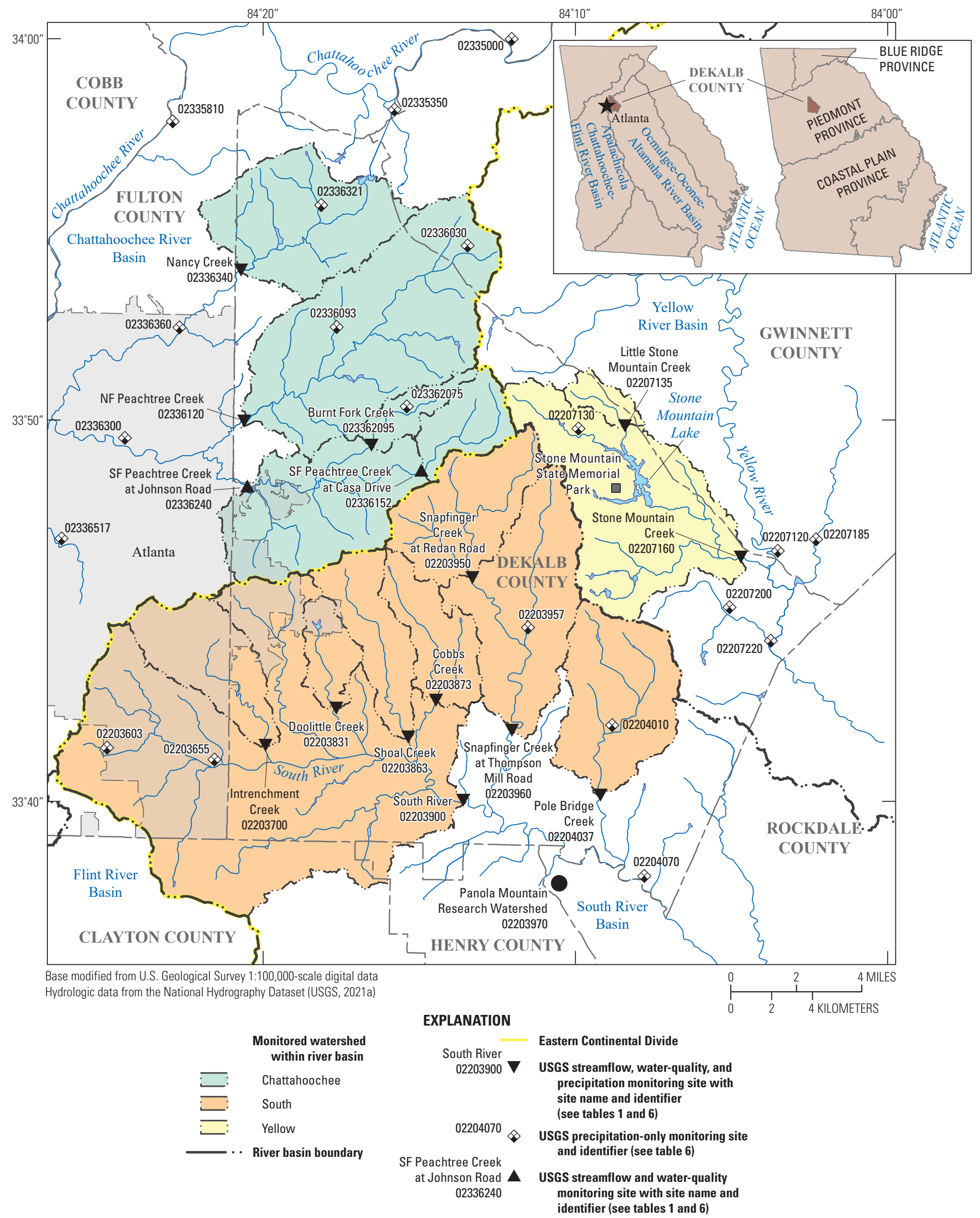

Figure 1. Location of the study area and the 15 monitored watersheds and U.S. Geological Survey (USGS) streamflow, water-quality, and precipitation monitoring sites, DeKalb County, Georgia. Abbreviations: NF, North Fork; SF, South Fork. 


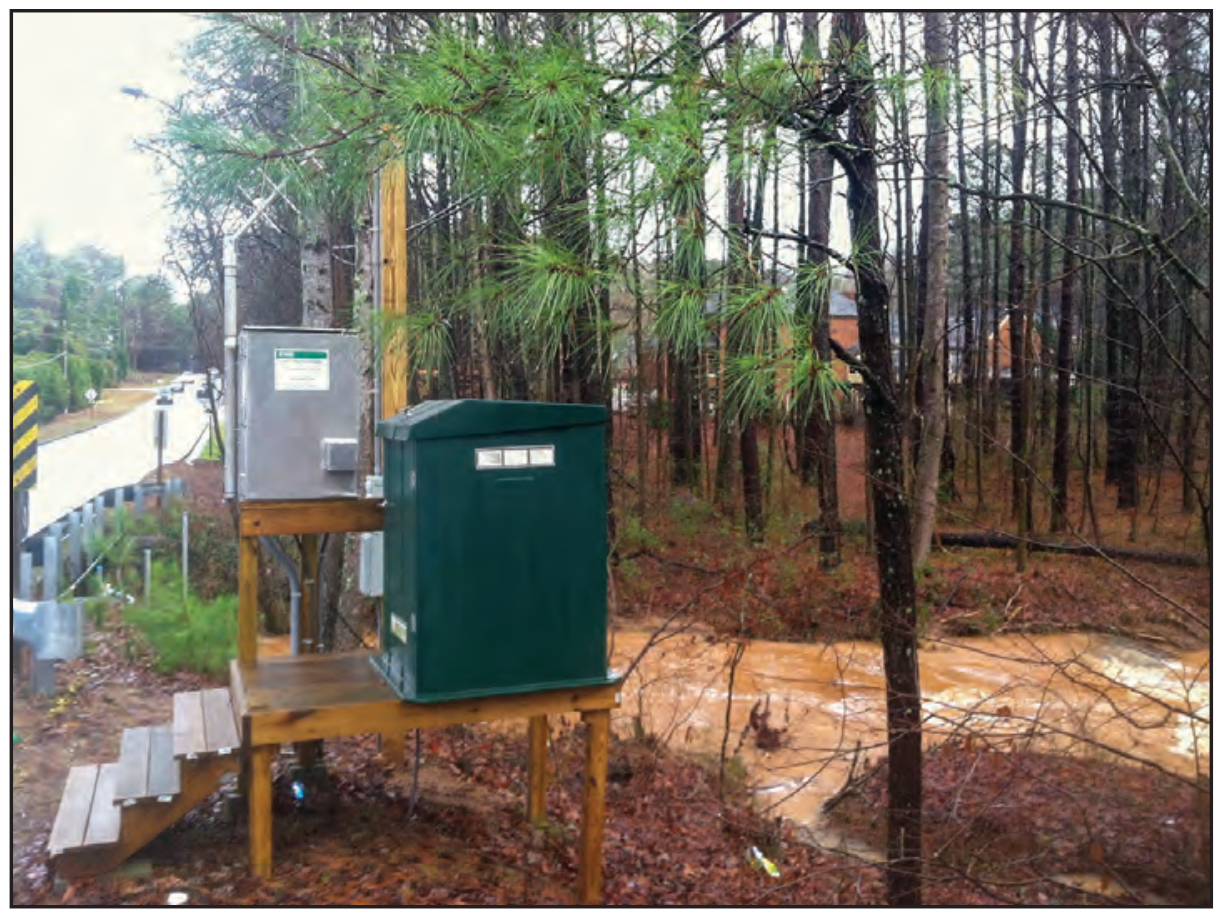

Figure 2. Multiparameter stream monitoring site, Little Stone Mountain Creek, DeKalb County, Georgia, August 2017 (U.S. Geological Survey site number 02207135). Photograph by Andrew E. Knaak, U.S. Geological Survey.

\section{Description of Study Area}

DeKalb County, which encompasses 271.2 square miles $\left(\mathrm{mi}^{2}\right)$, is an urban area located in north-central Georgia and includes the easternmost part of the City of Atlanta (fig. 1). The county is in the Piedmont Physiographic Province, which is a hilly plateau region located between the Blue Ridge and the Coastal Plain provinces. The geology of the county is a mixture of complex and varied metamorphic rocks, predominantly mica schists, gneisses, and amphibolites (USGS, 2018). DeKalb County is composed predominantly of first- to thirdorder streams that drain into the Chattahoochee, South, and Yellow Rivers. The Chattahoochee River Basin is part of the Apalachicola-Chattahoochee-Flint River Basin, whereas the South and Yellow River Basins are part of the larger Ocmulgee River Basin. The Eastern Continental Divide runs approximately northeast-southwest across the county, which separates drainages that flow into the Gulf of Mexico (Chattahoochee River) from those that flow into the Atlantic Ocean (South and Yellow Rivers; fig. 1).

The 15 watersheds monitored as part of the DeKalb County long-term monitoring program are listed in table 1. Eight of the watersheds are in the South River Basin, two are in the Yellow River Basin, and five are in the Chattahoochee River Basin (fig. 1). Eight of the watersheds are "nested," indicating that they are subbasins that lie within the drainage area of one of the larger monitored watersheds. The Intrenchment Creek, Doolittle Creek, Shoal Creek, and Cobbs
Creek watersheds are subbasins of the South River watershed; the Snapfinger Creek at Redan Road watershed composes the upper two-fifths of the Snapfinger Creek at Thompson Mill Road watershed; the Little Stone Mountain Creek watershed is a subbasin of the Stone Mountain Creek watershed; and the South Fork Peachtree Creek at Casa Drive and the Burnt Fork Creek watersheds are subbasins of the South Fork Peachtree Creek at Johnson Road watershed. The Stone Mountain Creek watershed hydrology is affected by Stone Mountain Lake (fig. 1), a reservoir with a drainage area of $13.6 \mathrm{mi}^{2}$ which represents 48.4 percent of the watershed. Watersheds were selected for this study to ensure diverse basin characteristics and land use for evaluating streamflow quantity and quality characteristics, while also ensuring sufficient spatial coverage of the county area. The specific monitoring site locations were selected on the basis of the suitability for hydrologic instrumentation and personnel safety.

The watershed drainage areas were delineated and quantified by using the StreamStats web application (USGS, 2021c; table 1). Some site drainage areas differ slightly from what is stored in the USGS National Water Information System (NWIS) database (USGS, 2019). The watershed drainage areas range almost two orders of magnitude, from the smallest at $2.19 \mathrm{mi}^{2}$ (Little Stone Mountain Creek watershed) to the largest at $100.01 \mathrm{mi}^{2}$ (South River watershed). The watersheds cover an area of $256.3 \mathrm{mi}^{2}, 205.4$ of which lie within DeKalb County and compose 75.8 percent of the county. 
Table 1. Fifteen U.S. Geological Survey (USGS) water-quantity and water-quality monitoring sites included in the USGS-DeKalb County long-term monitoring program.

[Drainage areas for each site are from StreamStats (USGS, 2021c); †, Nested watershed]

\begin{tabular}{|c|c|c|c|}
\hline $\begin{array}{c}\text { USGS site } \\
\text { number } \\
\text { (fig. 1; USGS, } \\
\text { 2019) }\end{array}$ & Site name & $\begin{array}{l}\text { Site/watershed name used in this } \\
\text { report }\end{array}$ & $\begin{array}{l}\text { Drainage area } \\
\text { (square miles) }\end{array}$ \\
\hline \multicolumn{4}{|c|}{ South River Basin } \\
\hline 02203700 & Intrenchment Creek at Constitution Road, near Atlanta, Ga. & Intrenchment Creek & $10.76^{\dagger}$ \\
\hline 02203831 & Doolittle Creek at Flat Shoals Road, near Decatur, Ga. & Doolittle Creek & $4.16^{\dagger}$ \\
\hline 02203863 & Shoal Creek at Columbia Drive near Atlanta, Ga. & Shoal Creek & $8.63^{\dagger}$ \\
\hline 02203873 & Cobbs Creek at Rainbow Drive, near Decatur, Ga. & Cobbs Creek & $7.97^{\dagger}$ \\
\hline 02203900 & South River at Flakes Mill Road near Atlanta, Ga. & South River & 100.01 \\
\hline 02203950 & Snapfinger Creek near Decatur, Ga. & Snapfinger Creek at Redan Road & $13.15^{\dagger}$ \\
\hline 02203960 & Snapfinger Creek at Thompson Mill Road near Lithonia, Ga. & $\begin{array}{l}\text { Snapfinger Creek at Thompson } \\
\text { Mill Road }\end{array}$ & 32.55 \\
\hline 02204037 & Pole Bridge Creek at Evans Mill Road near Lithonia, Ga. & Pole Bridge Creek & 16.06 \\
\hline \multicolumn{4}{|c|}{ Yellow River Basin } \\
\hline 02207135 & Little Stone Mountain Creek near Stone Mountain, Ga. & Little Stone Mountain Creek & $2.19 \dagger$ \\
\hline 02207160 & Stone Mountain Creek at GA 124, near Lithonia, Ga. & Stone Mountain Creek & 28.08 \\
\hline \multicolumn{4}{|c|}{ Chattahoochee River Basin } \\
\hline 02336120 & North Fork Peachtree Creek, Buford Highway, near Atlanta, Ga. & North Fork Peachtree Creek & 34.16 \\
\hline 02336152 & South Fork Peachtree at Casa Drive, near Clarkston, Ga. & $\begin{array}{l}\text { South Fork Peachtree Creek at } \\
\text { Casa Drive }\end{array}$ & $5.67 \dagger$ \\
\hline 023362095 & Burnt Fork Creek at Millwood Way near Clarkston, Ga. & Burnt Fork Creek & $3.25 \dagger$ \\
\hline 02336240 & South Fork Peachtree Creek Johnson Road, near Atlanta, Ga. & $\begin{array}{l}\text { South Fork Peachtree Creek at } \\
\text { Johnson Road }\end{array}$ & 27.62 \\
\hline 02336340 & Nancy Creek at Johnson Ferry Road, at Chamblee, Ga. & Nancy Creek & 17.79 \\
\hline
\end{tabular}

\section{Watershed Characteristics}

Land-surface elevations, used to make an elevation map of the study area, were downloaded from the USGS 3D Elevation Program (3DEP; USGS, 2017) at a 1/3-arc-second resolution (approximately a $34-$ foot [ft] or 10 -meter [m] grid). Land-surface slopes and topographic wetness indexes were derived from the elevations by using geographic information system (GIS) software functions. The topographic wetness index is a measure to quantify topographic control on hillslope hydrologic processes and is a function of surface slope and the upstream contributing area, which is dependent on the channel network topology (Beven and Kirkby, 1979).

Land use data were obtained from the Atlanta Regional Commission LandPro 2012 dataset (Atlanta Regional Commission, 2012). The dataset was derived by photographic interpretation and digitizing of 2009 true color ortho-rectified aerial photography with a $1.64-\mathrm{ft}$ pixel resolution. The dataset contained 29 land use categories that were combined into 8 groups that had similar land use attributes and (or) levels of development in order to simplify presentation of watershed land use characteristics (table 2). The percent developed imperviousness dataset was obtained from the National Land Cover Database (NLCD) 2011 dataset (USGS, 2011; Homer and others, 2015). The NLCD dataset is derived from Landsat imagery and has a grid size of $30 \mathrm{~m}$. Percent developed imperviousness, referred to as imperviousness herein, represents urban impervious surfaces as a percentage of developed surface in each 30-m pixel and was modeled by using regression tree algorithms. Impervious areas were also determined within 100- and 200-ft stream buffers from the 1:100,000-scale National Hydrography Dataset flowlines (USGS, 2021a) because these areas are more likely connected to the stream and storm drainage network that better reflect the effective impervious area of a watershed (directly connected impervious area). Effective impervious area is considered a better metric than overall watershed imperviousness regarding the effects of impervious area on storm runoff but is difficult to delineate because of the complex routing of water, particularly in urban watersheds. Land use and impervious area data were combined to determine the average impervious area of the various land use groups. 
Table 2. Summary of the land use classification system in this study.

[Land use groups are from the Atlanta Regional Commission (2012). Full descriptions of the land use groups are available in Atlanta Regional Commission (2012)]

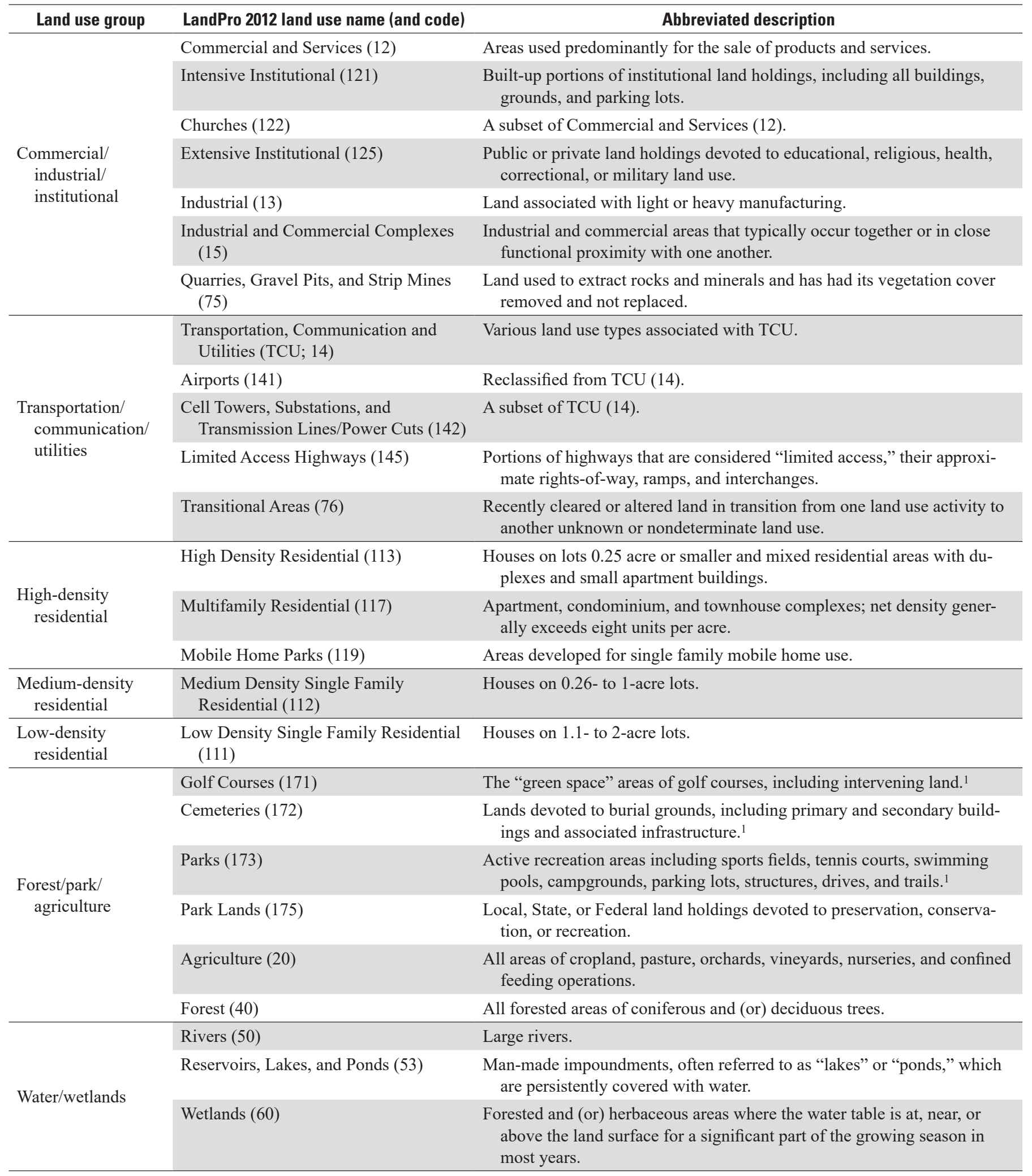


Table 2. Summary of the land use classification system in this study.-Continued

[Land use groups are from the Atlanta Regional Commission (2012). Full descriptions of the land use groups are available in Atlanta Regional Commission (2012)]

\begin{tabular}{|c|c|c|}
\hline Land use group & LandPro 2012 land use name (and code) & Abbreviated description \\
\hline \multirow{2}{*}{ Landfills/other } & Other Urban (17) & $\begin{array}{l}\text { Open land in intensive or indeterminate urban uses that do not require or } \\
\text { do not have structures. }\end{array}$ \\
\hline & Bare Exposed Rock (74) & $\begin{array}{l}\text { Naturally occurring areas of exposed bedrock with little or no vegetative } \\
\text { cover. }\end{array}$ \\
\hline
\end{tabular}

${ }^{1}$ Forest areas and ponds are often included in this category but may also be identified separately (codes 40 and 53, respectively) depending on their size.

Population density within the study area was determined for 2015 from the American community survey 5-year estimates of 2011-2015 block group data (U.S. Census Bureau, 2016). The census block group is the smallest geographic unit that the census provides data for, so it is the most appropriate dataset to use to estimate the population of small areas such as the study watersheds. Block group size varies with population density, and each group generally contains between 600 and 3,000 people with an optimum size of 1,500 people. Population density within each watershed was determined by clipping the census block group data by the watershed boundaries and area-weighting the block group population density data within each watershed. This methodology assumes that population density is uniform throughout the census block. Even though population density is not always uniform, this approach should reasonably estimate the population density of the watersheds, particularly in areas where the block group sizes are small or when blocks are predominantly within a single watershed.

\section{Surface-Water Monitoring}

Streamflow is monitored continuously at the outlets of the 15 monitored watersheds. The periods of record vary by site (table 3). The Intrenchment Creek, North Fork Peachtree Creek, and South Fork Peachtree Creek at Johnson Road sites have much longer streamflow records than the other 12 sites because they were established in 2003 as part of the City of Atlanta monitoring program. Standard USGS protocols are used for monitoring streamflow, which includes measuring stream stage (water-surface elevation), making discharge measurements, developing and maintaining a stage-discharge relation (rating curve), and computing streamflow (Rantz and others, 1982a, b). Stage is recorded every 15 minutes to the nearest $0.01 \mathrm{ft}$ and is routinely verified to an outside reference gage. This reference gage is periodically checked with surveying levels and other established reference marks to verify the gage vertical datum, and shifts are made when necessary. Discharge measurements are made over a wide range of hydrologic conditions to develop a stage-discharge relation at each monitoring site which is used to compute streamflow from the stage measurements. Discharge measurements are regularly made to continually refine the stage-discharge relation and to account for any temporal changes in the relation caused by changes in the shape of the streambed from the transport of sediment. Streamflow for periods of missing stage data is estimated from relations in hydrograph data with nearby basins having similar characteristics (Rantz and others, 1982b).

Daily average streamflow from each watershed was separated into base-flow and stormflow (quick flow) components by hydrograph separation. Base flow was used as a predictor variable of concentration models used to estimate streamwater constituent loads. Base flow and base-flow index (the proportion of base flow to total flow) were also used as indicators of groundwater recharge and the relative degree of storm runoff, and relations of these indicators with watershed characteristics were explored. Hydrograph separations were done on daily average streamflow by using the Web-based Hydrograph Analysis Tool (WHAT; Purdue University, 2019; Lim and others, 2005, 2010). The simple local minimum method was used, which required no parameters to be fit.

A multiparameter in situ water-quality meter, known as a sonde, was deployed at each site to measure water temperature, SC (sonde SC), dissolved oxygen (DO), sonde $\mathrm{pH}$, and sonde turbidity at 15-minute intervals (table 4). The sondes typically are cleaned and their calibration checked every 2 weeks, or more frequently following hydrologic events or after abnormal readings, which could be associated with fouling, instrument failure, or point sources or nonpoint sources of pollution. These water-quality monitors are maintained, and their corresponding sensor records are checked, corrected, or shifted by using the quality-assurance and quality-control procedures outlined in Wagner and others (2006). Poor-quality data are removed from the record and, unlike stage data, data are not estimated, resulting in data gaps in the continuous record.

Water quality was also determined from samples collected at the streamgages during base-flow and stormflow conditions. For the purposes of sampling, the year was divided into two seasons - summer (May through October) and winter (November through April). A minimum of one base-flow and three stormflow-composited samples were collected in each season for a minimum of eight samples a year. This sampling scheme was designed to identify variations in water quality 
Table 3. Dates when streamflow monitoring and water-quality sampling were established at the 15 U.S. Geological Survey (USGS) sites included in the USGS-DeKalb County long-term monitoring program.

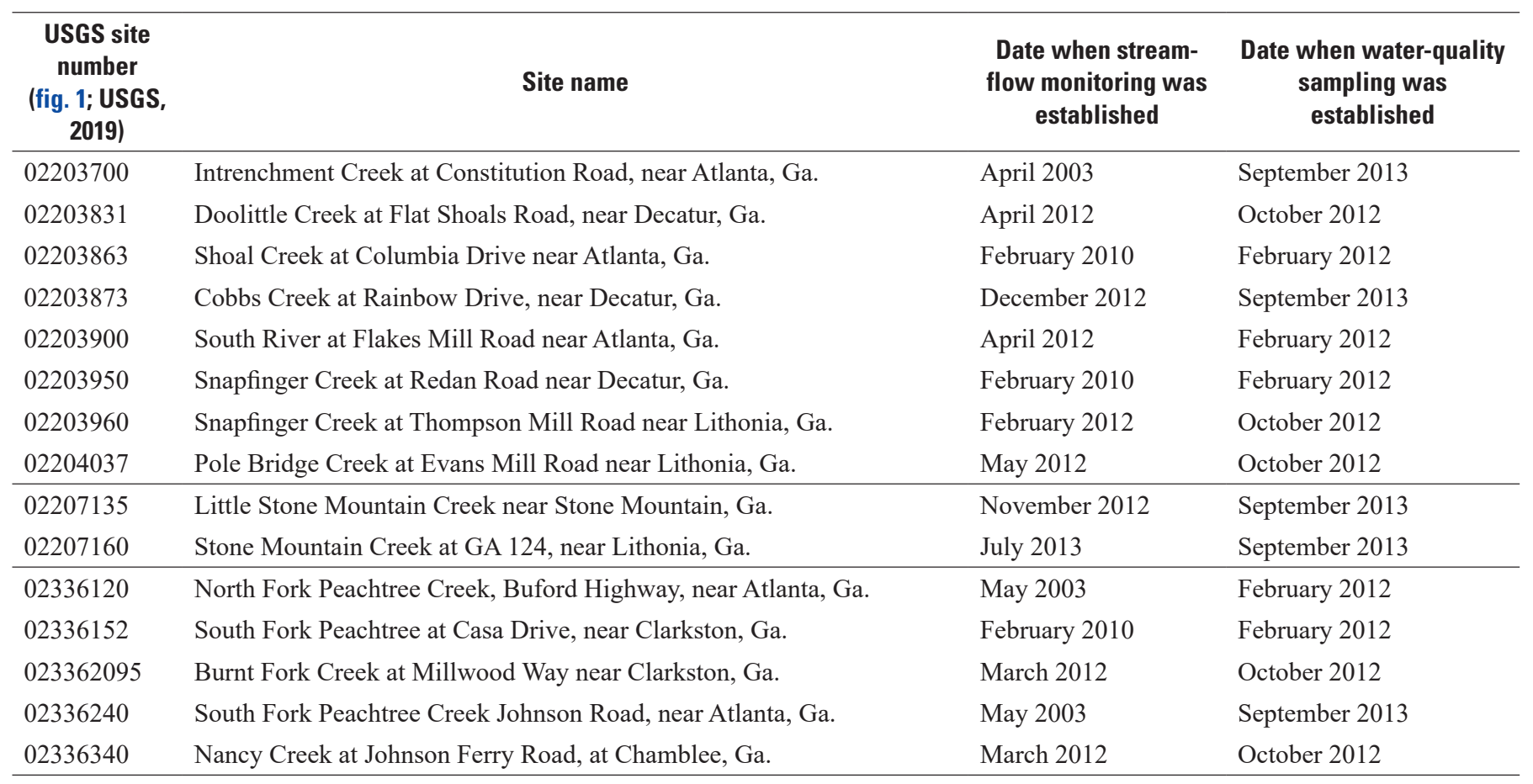

both hydrologically and seasonally. Water-quality results were included beyond the end of the study period through September 2017 to increase the number of samples included in the calibration datasets of the load and bacteria models.

Base-flow samples were collected by using a USGS DH-81 manual sampler and depth-integrated, equal-widthincrement (EWI) integrating techniques to ensure a representative sample as outlined in the National Field Manual for the Collection of Water-Quality Data (USGS, variously dated). If streamflow velocity was below 1.5 feet per second $(\mathrm{ft} / \mathrm{s})$, samples were considered multivertical grab samples; at streamflow velocities above $1.5 \mathrm{ft} / \mathrm{s}$, samples were considered true isokinetic samples. Base-flow samples were collected after no more than 0.1 inch of precipitation had fallen during the previous 72 hours. During base-flow sampling, a calibrated water-quality multiparameter sonde was used to concurrently measure the field properties of water temperature, SC, DO, $\mathrm{pH}$, and turbidity.

Stormflow samples were collected as a single streamflowweighted composite sample such that its water-quality was assumed to be representative of the constituent concentration variations that occurred during an event. Stormflow sampling protocols required event precipitation to be a minimum of 0.3 inch. Additionally, a minimum of 72 hours was required between each event to ensure that the events were discrete and that the measured water-quality properties were associated with the sampled event. Stormflow samples were collected by using automatic samplers that pumped water from a designated point in the stream. Samplers were maintained and calibrated in accordance with manufacturer protocols. Prior to each sampling event, the automatic sampler tubing and intake were cleaned and prepared in accordance with USGS field methods protocol (USGS, variously dated). The sampler was programmed to begin sampling when specified precipitation and (or) stage thresholds were reached. The composite sample was collected by using the constant volume, time proportional to flow volume increment protocol (EPA, 1992), in which a sample of equal volume is collected each time a specified volume of water flows by the site. This sample pacing volume was set prior to each sampling event with the intent of sampling throughout the duration of the storm hydrograph. A high enough pacing volume was necessary to provide a sufficient sample volume for analysis, while a low enough pacing volume was necessary to cover as much of the storm hydrograph as possible before filling up the sampler. This volume was determined for each watershed from the storm's expected runoff response, which was estimated from previous runoff responses to precipitation events with similar amounts, durations, and intensities as the predicted event and with similar watershed antecedent wetness conditions. The storm-composite samples often did not cover the full stormflow hydrograph because of the uncertainties in estimating the sample pacing but were acceptable if they included a portion of the hydrograph recession. The samplers were programmed to collect up to 25 half-liter aliquots during each storm into a single carboy. The samples were refrigerated in the automatic sampler at about 4 degrees Celsius $\left({ }^{\circ} \mathrm{C}\right)$ and were retrieved from the sampler within 24 hours of the end of an event. 
Table 4. Water-quality constituents measured and analyzed for samples collected in streams in Dekalb County, Georgia, units of measure, and predominant laboratory reporting limits.

[USGS, U.S. Geological Survey; ${ }^{\circ} \mathrm{C}$, degrees Celsius; na, not applicable; $\mu \mathrm{S} / \mathrm{cm}$, microsiemen per centimeter; <, less than; FNU, Formazin Nephelometric Units; $\mathrm{mg} / \mathrm{L}$, milligram per liter; $\mu \mathrm{g} / \mathrm{L}$, microgram per liter; N, nitrogen; P, phosphorus; C, carbon; cfu, colony forming units; mL, milliliter; MPN, most probable number]

\begin{tabular}{|c|c|c|c|c|c|}
\hline $\begin{array}{c}\text { USGS } \\
\text { parameter } \\
\text { code }\end{array}$ & Constituent & $\begin{array}{l}\text { Constituent } \\
\text { abbreviation }\end{array}$ & Unit & $\begin{array}{c}\text { Predominant } \\
\text { laboratory } \\
\text { reporting limit }\end{array}$ & $\begin{array}{c}\text { Percentage } \\
\text { of censored } \\
\text { samples }\end{array}$ \\
\hline 00010 & Water temperature ${ }^{1}$ & na & ${ }^{\circ} \mathrm{C}$ & na & na \\
\hline 00095 & Sonde specific conductance ${ }^{1}$ & sonde SC & $\mu \mathrm{S} / \mathrm{cm}$ at $25^{\circ} \mathrm{C}$ & $<5$ & 0.0 \\
\hline 90095 & Laboratory specific conductance & lab SC & $\mu \mathrm{S} / \mathrm{cm}$ at $25^{\circ} \mathrm{C}$ & $<5$ & 0.0 \\
\hline 00300 & Dissolved oxygen ${ }^{1}$ & DO & $\mathrm{mg} / \mathrm{L}$ & na & na \\
\hline 00310 & Biochemical oxygen demand & BOD & $\mathrm{mg} / \mathrm{L}$ & $<2$ & 17.8 \\
\hline 00340 & Chemical oxygen demand & COD & $\mathrm{mg} / \mathrm{L}$ & $<4.1$ & 1.4 \\
\hline 00400 & Sonde $\mathrm{pH}^{1}$ & na & $\mathrm{pH}$ & na & na \\
\hline 00403 & Laboratory $\mathrm{pH}$ & lab $\mathrm{pH}$ & $\mathrm{pH}$ & na & na \\
\hline 63675 & Laboratory turbidity & lab turbidity & FNU & $<0.5$ & 0.0 \\
\hline 63680 & Sonde turbidity ${ }^{1}$ & na & FNU & $<0.5$ & 0.0 \\
\hline 99913 & Turbidity - event mean ${ }^{1}$ & event turbidity & FNU & $<0.5$ & 0.0 \\
\hline 00530 & Total suspended solids & TSS & $\mathrm{mg} / \mathrm{L}$ & $<2$ & 16.1 \\
\hline 80154 & Suspended-sediment concentration & $\mathrm{SSC}$ & $\mathrm{mg} / \mathrm{L}$ & $<1$ & 0.0 \\
\hline 00600 & Total nitrogen ${ }^{2}$ & $\mathrm{TN}$ & $\mathrm{mg} / \mathrm{L}$ as $\mathrm{N}$ & $<1.1$ & 15.2 \\
\hline 00630 & Total nitrate plus nitrite & $\mathrm{NO}_{3}+\mathrm{NO}_{2}$ & $\mathrm{mg} / \mathrm{L}$ as $\mathrm{N}$ & $<0.01$ & 3.9 \\
\hline 00625 & Total ammonia plus organic nitrogen & TKN & $\mathrm{mg} / \mathrm{L}$ as $\mathrm{N}$ & $<0.18$ & 11.8 \\
\hline 00608 & Dissolved ammonia & $\mathrm{NH}_{3}$ & $\mathrm{mg} / \mathrm{L}$ as $\mathrm{N}$ & $<0.2$ & 11.8 \\
\hline 00665 & Total phosphorus & ТP & $\mathrm{mg} / \mathrm{L}$ as $\mathrm{P}$ & $<0.005$ & 1.7 \\
\hline 00666 & Dissolved phosphorus & DP & $\mathrm{mg} / \mathrm{L}$ as $\mathrm{P}$ & $<0.005$ & 10.1 \\
\hline 00680 & Total organic carbon & TOC & $\mathrm{mg} / \mathrm{L}$ as $\mathrm{C}$ & $<2$ & 0.2 \\
\hline 00916 & Total calcium & $\mathrm{Ca}$ & $\mathrm{mg} / \mathrm{L}$ & $<1$ & 0.2 \\
\hline 00927 & Total magnesium & $\mathrm{Mg}$ & $\mathrm{mg} / \mathrm{L}$ & $<1$ & 0.2 \\
\hline 01027 & Total cadmium & $\mathrm{TCd}$ & $\mu \mathrm{g} / \mathrm{L}$ & $<1$ & 72.6 \\
\hline 01025 & Dissolved cadmium & $\mathrm{DCd}$ & $\mu \mathrm{g} / \mathrm{L}$ & $<1$ & 92.9 \\
\hline 01042 & Total copper & $\mathrm{TCu}$ & $\mu \mathrm{g} / \mathrm{L}$ & $<0.2$ & 0.2 \\
\hline 01051 & Total lead & $\mathrm{TPb}$ & $\mu \mathrm{g} / \mathrm{L}$ & $<0.1$ & 0.4 \\
\hline 01092 & Total zinc & $\mathrm{TZn}$ & $\mu \mathrm{g} / \mathrm{L}$ & na & 0.0 \\
\hline 70300 & Total dissolved solids & TDS & $\mathrm{mg} / \mathrm{L}$ & $<5$ & 0.0 \\
\hline 31625 & Fecal coliform & na & $\mathrm{cfu} / 100 \mathrm{~mL}$ & $<1$ & 0.0 \\
\hline 50468 & Escherichia coli & E. coli & MPN/100 mL & $<1$ & 0.0 \\
\hline
\end{tabular}

${ }^{1}$ Consituent measured or determined from water-quality multiparameter sonde.

${ }^{2}$ Total nitrogen calculated as the sum of $\mathrm{NO}_{3}+\mathrm{NO}_{2}$ and TKN.

Because combined sewer overflow (CSO) events occasionally occur in the Intrenchment Creek watershed, sampler protocols were modified to avoid inclusion of sample aliquots influenced by CSO events. The Intrenchment Creek automatic sampler collected sample aliquots into separate bottles which were then composited at the USGS laboratory. Before compositing, possible CSO events were identified from storm hydrograph response (typically increased and [or] elevated flows during the hydrograph recession that were not related to precipitation) and increases in $\mathrm{SC}$ as indicated from the continuous water-quality sonde. When a CSO event was identified, sample aliquots collected after the initiation of the $\mathrm{CSO}$ event were not included in the storm-composite sample. The intended purpose of storm sampling was to capture typical 
water-quality responses to be used to develop concentration models to predict annual watershed loads and yields. Inclusion of CSO-affected storm samples in the concentration models could have resulted in biased load estimates. The monitoring program was not designed to capture and quantify the effects of infrequent events such as CSOs on water quality and loads.

The average streamflow measured during the collection of the aliquots that make up the composite sample is stored for each sample record in the USGS NWIS database (USGS, 2019). Because automatic samplers collected samples from a single point in the stream cross section, periodic concurrent EWI and automatic samples were collected. These samples were independently analyzed and compared to ensure that the automatic point sample was representative of the entire stream cross section.

Base-flow and stormflow samples were processed and preserved following USGS field methods (USGS, variously dated). Samples were analyzed for 24 water-quality constituents (table 4) using the analytical methods listed in table 5. Concentrations of suspended sediment were analyzed at the USGS Kentucky Sediment Laboratory, in Louisville, Kentucky. Fecal coliform and E. coli bacteria were analyzed at the USGS Georgia bacteria laboratory in Norcross, Ga. All other constituents were analyzed at RTI Laboratories in Livonia, Michigan. TN was calculated as the sum of $\mathrm{NO}_{3}+\mathrm{NO}_{2}$ and TKN. Base-flow and stormflow EWI samples were also measured concurrently for water temperature, sonde $\mathrm{SC}, \mathrm{DO}$, sonde $\mathrm{pH}$, and sonde turbidity by using a calibrated sonde brought out to the sampling site. Storm-composite samples were measured for sonde $\mathrm{SC}$, sonde $\mathrm{pH}$, and sonde turbidity at the Georgia sample preparation laboratory in Norcross, Ga., from a churn used to ensure a representative water-quality subsample. Storm-composite sample event turbidity was calculated as the average of turbidities at the times of sampling from the in situ sonde. Units of measurement, predominant laboratory reporting limits (LRLs), and the percentages of censored concentrations for each constituent are listed in table 4 . A censored value occurs when a concentration is below its LRL and is indicated by a remark code of " $<$ " (less than) with its concentration set to the LRL. The LRLs for some constituents vary depending upon the use of laboratory sample dilutions and analytical performance.

Some inconsistencies in laboratory-reported censored values in the water-quality dataset were problematic and were removed from the dataset before summarizing the data and using the concentrations for estimating loads. Several constituents had censored concentrations that were higher than many of the uncensored values for that constituent (censored value and number of occurrences in parentheses): COD $(<20$ milligrams per liter $[\mathrm{mg} / \mathrm{L}] ; \mathrm{n}=21), \mathrm{TCu}(<5$ micrograms per liter $[\mu \mathrm{g} / \mathrm{L}] ; \mathrm{n}=6), \mathrm{TPb}(<1 \mu \mathrm{g} / \mathrm{L} ; \mathrm{n}=46)$, and TZn $(<50 \mu \mathrm{g} / \mathrm{L}$; $\mathrm{n}=13$ ). Furthermore, including these censored results in the load estimation calibration datasets resulted in poor model fits or prevented loads from being estimated. BOD concentrations were greater than (>) $3 \mathrm{mg} / \mathrm{L}$ in 11 samples; those were removed because there were many uncensored BOD concentrations above this value, and the USGS LOAD ESTimator software (LOADEST; Runkel and others, 2004) is not able to process "greater than" censored values.

Concentrations of suspended organic and inorganic particles in surface waters were quantified in this study by using two different laboratory analytical methods: SSC and TSS (Gray and others, 2000). The SSC analytical method involves measuring the dry weight of the sediment in an entire sample of a known volume, and the TSS method involves measuring the dry weight of the sediment in a subsample of the available sample volume, rather than the entire sample (Landers, 2013). Methods for processing SSC are described in Knott and others (1993) and Shreve and Downs (2005). The SSC analytical method is considered to produce more consistent results than the TSS method; however, the TSS method is often the method adopted for regulatory monitoring. Generally, a bias in relation to SSC and TSS is observed when sand-sized materials (diameters $>0.062$ millimeter $[\mathrm{mm}]$ ) are greater than 25 percent of the sediment dry weight, such that the SSC values tend to exceed their paired TSS values (Gray and others, 2000). This bias indicated TSS was a poor measure of suspended particles in stormwater when the dominant fraction was sand size or coarser.

Field water-quality blank and replicate samples were collected and analyzed in compliance with USGS protocols (USGS, variously dated; Mueller and others, 2015). These were used to identify possible sample contamination and assess the precision, accuracy, and representativeness of sampling methodology. The laboratories used for analysis have extensive quality-control and quality-assurance programs that include analysis of duplicates to ensure reproducibility and to assess method precision, and reference standards used for method validation. RTI Laboratories participates in the USGS Standard Reference Samples round-robin quality-assurance program (USGS, 2021b). An assessment of the quality-control and quality-assurance samples is provided in appendix 1.

All continuously monitored data (stage, precipitation, and water quality) are transmitted hourly by way of satellite communication and are available to the public from the USGS NWIS web interface as values and time-series plots (USGS, 2019). During periods of extreme runoff, each site is designed to send emergency transmissions every 15 minutes so that the public can receive the data in near real time. These transmissions occur when rainfall intensities exceed 2 inches per hour or when there are large rates of change in stage, as determined from thresholds defined for each site. The real-time data combined with the USGS WaterAlert tool can be used as a flood warning system for emergency managers and the public (USGS, 2013).

All stage, streamflow, precipitation, and continuous and sample water-quality data used in this study are available in the USGS NWIS database and can be obtained by using the USGS site numbers listed in tables 1 and 6 (USGS, 2019). 
Table 5. Summary of analytical methods used to quantify water-quality constituent concentrations of samples in streams in DeKalb County, Georgia.

[EPA, U.S. Environmental Protection Agency; ${ }^{\circ} \mathrm{C}$, degrees Celsius]

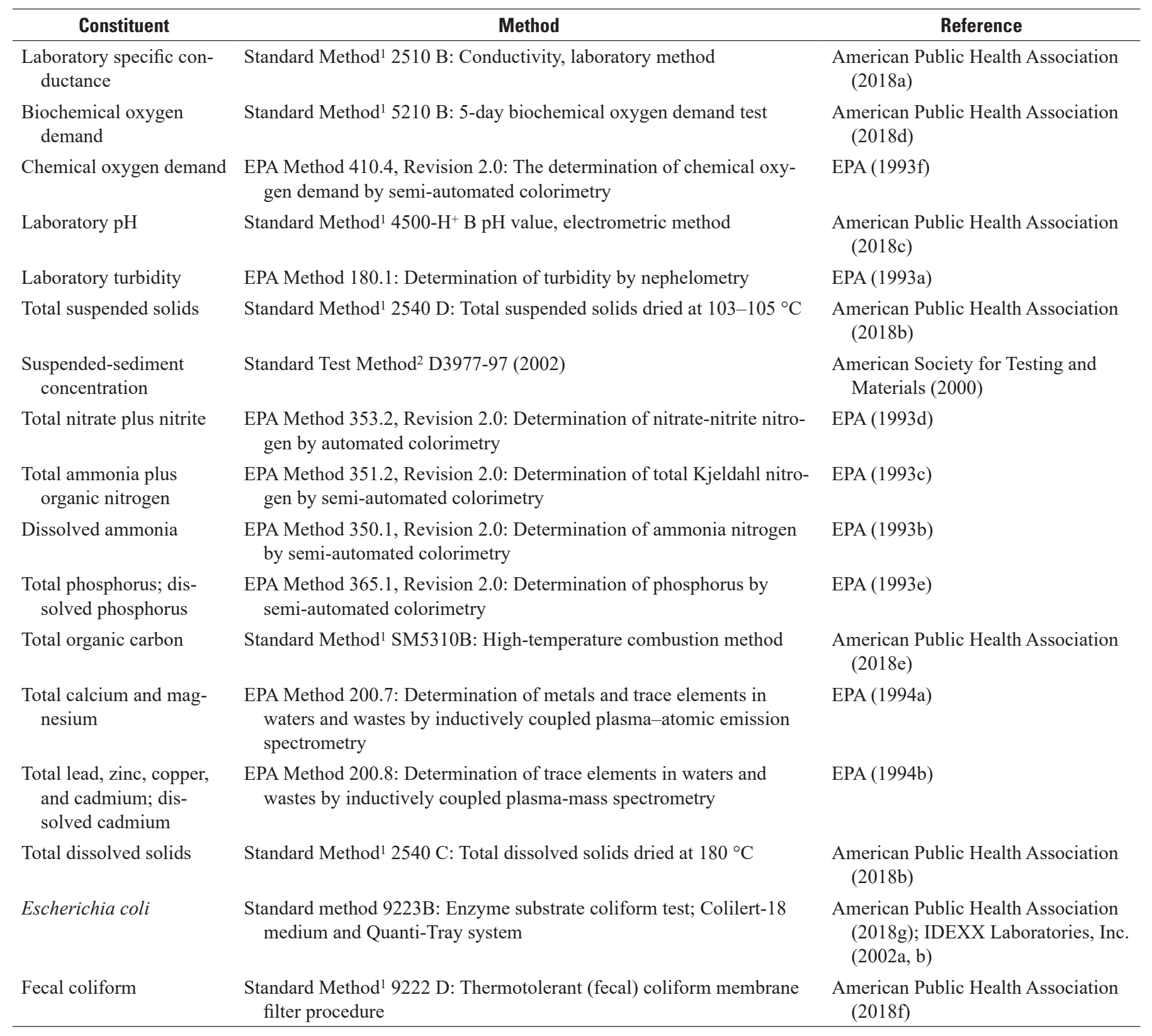

\footnotetext{
${ }^{1}$ Standard methods for the examination of water and wastewater.
}

${ }^{2}$ Standard test methods for determining sediment concentration in water samples.

\section{Precipitation}

Precipitation was measured and recorded at each site at 15-minute intervals, using self-calibrating tipping bucket rain gages that measure precipitation in 0.01 -inch increments. The rain gages were routinely cleaned and calibrated as per USGS protocols (USGS, 2009).
Watershed precipitation estimates are based on 33 USGS precipitation monitoring sites: 13 that are co-located with the streamgages at the watershed outlets and 20 additional sites within or adjacent to the study area (fig. 1; table 6). These sites are well distributed across and along the margins of the study area and should reasonably represent precipitation within the 15 watersheds. Daily precipitation within each watershed was approximated by averaging all available daily precipitation values, each weighted by the inverse distance squared between 
Table 6. U.S. Geological Survey (USGS) precipitation monitoring sites included in the study, including dates monitoring was established.

[Dates are in month/day/year format]

\begin{tabular}{|c|c|c|}
\hline $\begin{array}{l}\text { USGS site num- } \\
\text { ber (fig. 1; USGS, } \\
\text { 2019) }\end{array}$ & Site name & $\begin{array}{l}\text { Date when precip- } \\
\text { itation monitoring } \\
\text { was established }\end{array}$ \\
\hline 02203603 & South River at Springdale Road, at Atlanta, Ga. & $6 / 5 / 2007$ \\
\hline 02203655 & South River at Forrest Park Road, at Atlanta, Ga. & $11 / 20 / 2002$ \\
\hline 02203700 & Intrenchment Creek at Constitution Road, near Atlanta, Ga. ${ }^{1}$ & $4 / 4 / 2003$ \\
\hline 02203831 & Doolittle Creek at Flat Shoals Road, near Decatur, Ga. ${ }^{1}$ & $4 / 11 / 2012$ \\
\hline 02203873 & Cobbs Creek at Rainbow Drive, near Decatur, Ga. ${ }^{1}$ & $12 / 27 / 2012$ \\
\hline 02203900 & South River at Flakes Mill Road near Atlanta, Ga. ${ }^{1}$ & $4 / 5 / 2012$ \\
\hline 02203950 & Snapfinger Creek at Redan Road near Decatur, Ga. ${ }^{1}$ & $2 / 15 / 2010$ \\
\hline 02203957 & Barbashela Creek at Woodway Drive, near Stone Mountain, Ga. & $12 / 23 / 2014$ \\
\hline 02204070 & South River at Klondike Road, near Lithonia, Ga. & $2 / 6 / 2001$ \\
\hline 02207120 & Yellow River at GA 124, near Lithonia, Ga. & $4 / 26 / 1996$ \\
\hline 02207130 & Stone Mountain Creek at Silver Hill Road, near Stone Mountain, Ga. & $3 / 5 / 2013$ \\
\hline 02207135 & Little Stone Mountain Creek near Stone Mountain, Ga. ${ }^{1}$ & $3 / 7 / 2013$ \\
\hline 02207160 & Stone Mountain Creek at GA 124, near Lithonia, Ga. ${ }^{1}$ & 9/30/2013 \\
\hline 02207185 & No Business Creek at Lee Road, Below Snellville, Ga. & $3 / 1 / 2001$ \\
\hline 02207200 & Swift Creek near Lithonia, Ga. & $11 / 2 / 2012$ \\
\hline 02207220 & Yellow River at Pleasant Hill Road, near Lithonia, Ga. & $11 / 27 / 2002$ \\
\hline 02335000 & Chattahoochee River near Norcross, Ga. & $6 / 30 / 2002$ \\
\hline 023362095 & Burnt Fork Creek at Millwood Way near Clarkston, Ga. ${ }^{1}$ & $3 / 8 / 2012$ \\
\hline 02336300 & Peachtree Creek at Atlanta, Ga. & $2 / 1 / 2005$ \\
\hline 02336321 & Tributary to Nancy Creek at Peachford Drive, near Dunwoody, Ga. & $12 / 23 / 2014$ \\
\hline 02336340 & Nancy Creek at Johnson Ferry Road, at Chamblee, Ga. ${ }^{1}$ & $2 / 25 / 2012$ \\
\hline 02336360 & Nancy Creek at Rickenbacker Drive, at Atlanta, Ga. & $5 / 24 / 2003$ \\
\hline 02336517 & Proctor Creek at Hortense Way, at Atlanta, Ga. & $4 / 1 / 2003$ \\
\hline
\end{tabular}

${ }^{1}$ Precipitation monitoring site co-located with outlet of study watershed.

the centroid of the watershed and the precipitation monitoring sites (Shepard, 1968). Precipitation data were not available at all 33 sites for every day of the study period; many sites were added later in the study period, and occasional equipment malfunction or poor data quality resulted in short data gaps. Data coverage was generally good, with 96.6 percent of the days having data for 15 or more sites and 90.4 percent of the days having data for 20 or more sites. Precipitation estimates likely improved over time as additional rain gages were installed during the study period. 


\section{Runoff Metrics}

Various stream runoff metrics were used in this study to better understand aspects of the hydrologic cycle. Runoff herein refers to streamflow (channel runoff) as opposed to surface runoff. The runoff ratio (runoff coefficient or water yield) is the portion of precipitation that results in runoff (runoff divided by precipitation). The base-flow index (BFI) is the long-term proportion of the base-flow component of runoff, as determined from hydrograph separation (WHAT; Purdue University, 2019; Lim and others, 2005, 2010). Stormflow runoff represents the remaining portion of runoff after removing base-flow runoff.

\section{Stream-Water Constituent Load Estimation}

Loads were estimated for each of the 15 watersheds on an annual basis for up to 5-year periods during water years 2012-16. The starting year for load estimation was dependent upon when streamflow measurements and water-quality sampling were initiated (table 3). Loads were estimated for 15 constituents: BOD, COD, TSS, SSC, TN, $\mathrm{NO}_{2}+\mathrm{NO}_{3}$, TP, $\mathrm{DP}, \mathrm{TOC}, \mathrm{Ca}, \mathrm{Mg}, \mathrm{TCu}, \mathrm{TPb}, \mathrm{TZn}$, and TDS. Loads were estimated by using one of two methods depending on the strength of a site's constituent "flow-turbidity" concentration-model relation. A regression-model method was used if the constituent had a moderate to strong concentration-model relation (model-adjusted coefficient of determination $\left[\mathrm{R}^{2}\right] \geq 0.20$ ), whereas the Beale ratio estimator was used if the constituent had a weak concentration-model relation (model-adjusted $\mathrm{R}^{2}<0.20$ ).

\section{Background}

Constituent load, often referred to as mass flux, is the mass of chemical solutes or sediment transported past a point in a stream during a specified period. Constituent load $(L)$ is the product of constituent concentration $(C)$ and streamflow $(Q)$ integrated over time $(t)$ :

$$
L=\int C(t) Q(t) d t
$$

where $d$ indicates the derivative of $t$. Load estimation using the integral in equation 1 requires a continuous record of both concentration and streamflow. Although streamflow can readily be measured in a nearly continuous manner, constituent concentration typically is measured less frequently because of the effort and expense of collecting and analyzing samples for water quality. Various techniques have been developed to estimate loads using discrete concentration observations. These techniques can be categorized into four classes: (1) averaging methods, (2) period-weighted approaches (for example, Likens and others, 1977; Larson and others, 1995), (3) regressionmodel (or rating-curve) methods, and (4) ratio estimators (for example, Dann and others, 1986; Preston and others, 1989).
Aulenbach and others (2016) indicated that for studies such as this one with relatively infrequent sampling, the most appropriate load estimation method depends upon the strength of its concentration-model relation. For constituents that have moderate to strong concentration-model relations, a regressionmodel method was deemed most appropriate and was used to estimate loads. For constituents that had weak concentrationmodel relations (concentration-model $\mathrm{R}^{2}<0.20$ ), the Beale ratio estimator was used to estimate loads (Beale, 1962).

In a regression-model approach, $C(t)$ is estimated continuously by using a regression model that relates concentration to continuously measured explanatory variables, such as streamflow and day of year (Johnson, 1979; Crawford, 1991; Cohn and others, 1992). The concentration model predicts the expected average concentration response to the combination of conditions described by the model variables. Loads can then be directly calculated from the streamflow data and modeled $C$ by using equation 1 with a sufficiently small time step to ensure accuracy. Regression-model approach load estimates can be further improved by the inclusion of surrogate waterquality time-series data as explanatory variables. Surrogate variables that are closely related to the modeled constituent typically reflect chemically or physically related temporal variations better than empirically related explanatory variables such as streamflow.

The Beale ratio estimator is a commonly used ratio estimator approach when an average sample-estimated load is scaled by its ratio of the annual average and sample average streamflows, which is then adjusted by a bias correction factor (Beale, 1962). In a load estimation evaluation study using a constituent that did not have a strong concentrationstreamflow relation (TP), the Beale ratio estimator statistically outperformed other averaging and regression-model-based approaches (Dolan and others, 1981). The Beale ratio estimator is a well-suited load estimation approach for studies which have few discrete concentration samples (Quilbé and others, 2006).

\section{Regression-Model Load Estimation Methods}

The regression-model load estimation methods used herein are similar to those developed and implemented in Landers and others (2007), Joiner and others (2014), and Aulenbach and others (2017a) for similar analyses of urban streams in Gwinnett County, Ga. Modifications made to these methods are detailed herein and in appendix 2. Loads were estimated by using the USGS LOADEST software (Runkel and others, 2004) with the adjusted maximum likelihood estimates (AMLE) algorithm (Cohn, 1988; Cohn and others, 1989, 1992). The AMLE approach appropriately processes censored water-quality data - concentrations that are below the analytical detection limit — such that load estimates have negligible bias (Cohn and others, 1992). The AMLE approach assumes that model residuals are normally distributed with constant variance; results for censored data may not be optimal if data are not normally distributed. The AMLE algorithm 
applies a correction factor to account for retransformation bias of a logarithmic model transformed back to linear space (Ferguson, 1986) to provide a "nearly unbiased" estimate of load (Cohn, 1988). The TIBCO Spotfire S+ statistical software (version 8.1) implementation of the LOADEST computer code was used in this analysis.

The typical regression-model load estimation method requires modification to incorporate the use of stormcomposite samples. When estimating loads, it is inappropriate to predict concentrations from instantaneous streamflow when the concentration-streamflow relation was developed from storm average streamflow of the storm-composite samples because the storm-composite and instantaneous concentrationstreamflow relations can differ from each other and can result in substantial bias in the load estimates. Thus, the approach developed by Landers and others (2007) in which loads are estimated from average streamflow based on a predetermined computational time step using a storm-composite concentration-streamflow relation was used for this study. This time step represents a typical storm duration, which was estimated for each watershed and ranged from 3 to 12 hours. Base-flow discrete samples can be reasonably incorporated into the storm-composite concentration-streamflow relation because, during base-flow conditions, streamflow does not change rapidly such that instantaneous and average streamflows would not be substantially different. Although this approach should reduce bias that would result from treating composite storm sample concentrations as a function of instantaneous streamflow, this methodology has some shortcomings. The computational time steps do not always properly reflect the stormflow periods for several reasons: (1) the splitting of a storm into two time steps because of the fixed time-interval of the time steps (necessary for using LOADEST) relative to the timing of the storms, (2) the inclusion of base flow in a time step when the storm response is shorter than the time step, and (3) the splitting of storms longer than a time step into multiple time steps. These issues result in poor representation of the storm average streamflow within individual time steps. The overall storm streamflow is represented in the load estimates when the time steps are combined, but the load estimates could conceivably be biased, particularly in situations when the concentration-streamflow model relations are not particularly linear. However, the adoption of the time-step approach should still be superior than the alternative of treating stormcomposite sample average streamflows as instantaneous streamflows in the load estimation approach.

The computational time step is related to the average duration of hydrograph response, which is a combination of many factors including storm precipitation duration and spatial distribution, watershed drainage area, stormflow routing, and attenuation. The time step is longer for larger watersheds because of the integration of runoff over a larger area with longer and more varied travel times to the watershed outlet as well as the attenuation of the storm hydrograph as the runoff travels downstream, which lengthens the hydrograph response time with respect to the duration of precipitation. Time steps were determined from the storm-composite water-quality sample durations at each site because the sample chemistry represents those durations. Note that the storm-composite samples often do not represent the entire stormflow hydrograph because of uncertainties in determining the ideal sample pacing volume prior to the storm. Storm sample durations were not normally distributed and were positively skewed because longer duration rainfall events occur less frequently. The time steps, therefore, were determined from the average of the 25th and 75th percentiles of the durations to better reflect the non-normal distribution of durations rather than a mean or median value that just reflects the central tendency. The median duration has been employed in previous analyses (Aulenbach and others, 2017a). A factor of 24 hours (3, 4, 6, 8, or 12 hours) nearest to the representative storm duration was selected as the time step for each site so the time step would not result in load estimates being split across days. Storm periods determined by hydrograph separation were found to be longer than storm-composite sample durations because of the longer recession periods before the return to base-flow conditions as determined from the separation procedure.

A nine-parameter regression model was developed for estimating loads in LOADEST, and this has the form of the natural logarithm of load as a function of variables including streamflow, base flow, season, and turbidity:

$$
\begin{aligned}
\ln (L)= & a_{0}+a_{1} S+a_{2} \ln Q+a_{3}(1-S) \ln Q+a_{4} \ln Q_{b} \\
& +a_{5} \ln T+a_{6} S \ln T+a_{7} \sin \theta+a_{8} \cos \theta
\end{aligned}
$$

where

$$
\begin{aligned}
& L \text { is load and is the product of concentration and } \\
& \text { streamflow; } \\
& a_{0} \ldots a_{8} \text { are fitted parameter coefficients; } \\
& S \text { is an indicator variable that indicates the } \\
& \text { flow condition, } 0 \text { for base flow and } 1 \text { for } \\
& \text { stormflow; } \\
& Q \text { is streamflow, in cubic feet per second; } \\
& Q_{b} \text { is daily base flow, in cubic feet per second; } \\
& T \text { is turbidity, in Formazin Nephelometric } \\
& \theta \text { Units; and } \\
& \theta \text { is } 2 \pi d o y / 365.25, \text { where doy is day of year. }
\end{aligned}
$$

Even though LOADEST uses equation 2 to define load, this equation is referred to as the concentration model in this report. This is just a matter of semantics because equation 2 could also be written as a function of concentration but is already multiplied by streamflow as per equation 1 and has no effect on the estimation of loads. Loads were modeled in logarithmic space, and models used logarithmic transformations of streamflow and turbidities which linearized their relations-a necessary requirement for multiple linear regression. These transformations also adjusted the error distribution such that they had more equal variance across the range of loads and were more normally distributed. These are required attributes for well-posed models. Seasonality was fit with a pair of sine and cosine functions of day of year, which allows for the 
model parameters to be fit by using multiple linear regression while being mathematically equivalent to a sinusoidal function with a phase shift that normally requires a nonlinear fit. Timetrend terms, which are often used in load regression models, were excluded in this study because of the short 5 -year or less calibration periods. If trend terms were to have been included in the model, trends may have been influenced by the strong pattern in climate going from drier to wetter conditions over the study period.

The variables in equation 2 were included in the models based on their ability to explain some of the variations in constituent concentrations. Concentrations commonly vary with streamflow, $Q$, with many of the sediment-related constituent concentrations typically increasing with increasing $Q$ (enhancement), whereas other constituents exhibit decreasing concentrations with increasing $Q$ (dilution). The daily baseflow variable, $Q_{b}$, captures the effects of variability in climatic status of a watershed on water quality. The variable $Q_{b}$ was calculated by hydrograph separation of daily average streamflow as previously described. Turbidity acts as a water-quality surrogate for sediment and predominantly particulate-bound constituents and is particularly useful for improving load estimates of these constituents. Near-continuous turbidity data were measured from the water-quality sondes. Seasonal variations in concentrations can be the result of changes in seasonal inputs to the watersheds, seasonal changes in biogeochemical processes, and seasonal variations in climate if not modeled by $Q_{b}$.

Levels of turbidity or streamflow were used to determine the base-flow or stormflow condition indicator variable $S$ for each load estimation computational time step, as opposed to determining hydrologic conditions directly from the dynamics of the stream hydrograph using hydrograph separation. For the streams in this study, turbidities were much less than 20 Formazin Nephelometric Units (FNU) during base-flow conditions, were typically $>20$ FNU during stormflow conditions, and were infrequently near $20 \mathrm{FNU}$, generally only during transitions between base-flow and stormflow conditions. Hence, $S=1$ (stormflow conditions) was defined as when turbidity from the water-quality sondes was greater than or equal to this 20 -FNU threshold. If turbidity data were missing, then streamflow was used to determine stormflow conditions. The stormflow cutoff was calculated for each watershed as the mean streamflow of all unit-value turbidities between 18 and $22 \mathrm{FNU}$ ( \pm 10 percent of the 20 -FNU threshold) and was calculated on a monthly basis because of seasonal variations in the relation between turbidity and streamflow. The time-step flow condition was then calculated as the average of $S$ of the associated unit-values.

The model form was designed with the flexibility to be able to simultaneously fit both base-flow and storm-composite samples, which represent two distinct flow regimes. In some cases, these two sample types follow a single concentration relation, whereas in other cases they have distinct concentration relations. The model parameters were formulated to allow for differences in the model intercept and differences in the slope of the streamflow and turbidity relations while fitting a single relation for $Q_{b}$ and seasonal variables. The indicator variable $S$ was used to indicate whether hydrologic conditions of the sample were during base flow $(S=0 ; 1-S=1)$ or stormflow $(S=1)$. The indicator variable controls the absence (multiplied by 0 ) or presence (multiplied by 1 ) of the model term in equation 2 . An overall model intercept was fit by the $a_{0}$ term, while an additional offset $a_{1} S$ was fit by using only the stormflow samples. The overall concentration-streamflow relation was fit for both flow conditions, $a_{2} \ln Q$, whereas any differences in this slope during base-flow conditions were adjusted by using the $a_{3}(S-1) \ln Q$ term. The concentration-turbidity relation was fit by using the term $a_{5} \ln T$ for all conditions and by using the $a_{6} S \ln T$ term during stormflow conditions. This model framework expedites the model fitting process by reducing the number of models to be fit by one-half.

To prevent gaps in load estimates that were caused by data gaps in turbidity, a second model without turbidity terms was fit to estimate loads when turbidity was missing. Gaps are to be expected in continuous water-quality sensors because of their high maintenance requirements and propensity for malfunctions. The model that contains turbidity term(s) is referred to as the "flow-turbidity model," and the model without turbidity is referred to as the "flow-only model." Flow-turbidity models were not present for all constituentwatershed combinations because model turbidity terms were sometimes not significant. Annual loads were calculated by summing the computational time-step estimates of load for the flow-turbidity model while substituting the loads from the flow-only model when turbidity was missing for that time step. To properly estimate the uncertainty in the load estimates (described later), the time-step files for estimating loads were modified so that the flow-only and flow-turbidity model loads reflected only their respective time steps used in the overall load estimates. Because LOADEST does not allow missing time steps, small streamflow and turbidity values were substituted into the relevant estimation file for time steps that were not used such that only a small load would be estimated for those time steps. These small loads do not appreciably affect the LOADEST load and uncertainty estimates. Timestep streamflows were set to 0.01 cubic foot per second $\left(\mathrm{ft}^{3} / \mathrm{s}\right)$, and $\ln T \mathrm{~s}$ were set to a value of -2 . This approach of assessing uncertainty from just the time steps that were used to estimate overall load is an improvement over past methodology, such as that used in Aulenbach and others (2017a).

The optimal set of model terms included in equation 2 was determined by using a forward stepwise regression and the corrected Akaike Information Criterion (AICc; Akaike, 1974; Burnham and Anderson, 2002). The AICc selects the best predictive model parameters for a given calibration dataset. The AICc weighs the benefit of including additional parameters on model improvement versus the risk of overparameterization (overfitting), which is when models include variables that do not explain much of the variation in the concentrations. Whereas overparameterization does not necessarily bias model parameter estimates, it can inflate estimated 
model variances, thereby making model predictions appear less precise. The model-term selection process was done externally from LOADEST because LOADEST does not include a process for selecting the optimal set of model terms. Modelterm selection was done in the JMP statistical data analysis software, version 14.3.0 (SAS Institute Inc., 1989-2018), using an ordinary least squares (OLS) fitting approach. The OLS approach does not explicitly process censored concentrations, and half of the LRL was used as the concentrations for these samples (Helsel, 1990; EPA, 1991). The seasonal sine and cosine model terms worked as a single variable and as such were both included in a model if only one term was deemed significant in the model fit. Streamflow is a mandatory explanatory variable in the LOADEST model. If the streamflow term was not selected by the stepwise regression, the streamflow parameter was designated as a mandatory parameter and the forward stepwise regression was rerun. The streamflow parameter was not initially set to mandatory as to not interfere in the natural selection process because the stepwise regression selection process is influenced by the entry order of the parameters. The selected stepwise regression-model terms were then used in LOADEST to fit the model coefficients and estimate loads using the AMLE algorithm.

A model residual analysis was performed to assess model fits. Residuals were calculated as the observed minus the predicted loads and represent the unexplained variance (error) in the model. Residuals were examined to ensure that the errors in the models were random - having about equal variance both above and below the y-axis and across the range of values (also known as being identically distributed) - when plotted versus observed load and the model's explanatory variables (streamflow, turbidity, and day of year). Unequal variance above and below the y-axis indicates that the model is biased across this range of conditions and that errors are higher or lower than the overall estimate of uncertainty during those conditions. Unequal variance may indicate that the model is not well-posed and may need additional transformations to linearize the variable relations with concentrations or require additional explanatory variables to explain variations in concentration.

Model residuals were also evaluated to determine if they were normally distributed. Normality was determined from the Turnbull-Weiss normality test statistic (Turnbull and Weiss, 1978 ) in which the test statistic $p$-value $<0.05$ indicates that the residuals were not from a normal distribution. Normality was also assessed from normal quantile plots when normalized residuals were plotted versus a standard normal distribution with normality indicated by a close fit to the one-to-one line. If residuals are not normally distributed, it can bias the model parameter fit, and the AMLE approach may not provide optimal load estimates for censored data (Runkel and others, 2004). The expected normal distribution of errors would also not be correct; however, McCulloch and Neuhaus (2012) indicated that OLS parameter estimates were still robust for non-normal distributions that exhibited skew (unsymmetrical) or kurtosis (heavy-tailed) but were still unimodal.
An outlier analysis was performed during the fitting process to determine outlier concentrations that would have high influence on the fit of the concentration relation (Helsel and others, 2020), and these outliers were removed as to not affect model predictions. Outliers can have an undue influence on the model fit because of the minimization of the squared errors fitting process that gives outliers greater weights. These outliers were not necessarily in error but may represent some condition that occurs infrequently when it would be inappropriate to adjust the model toward such an ephemeral condition. The model predictions represent the normal range of conditions and not the uncommon ephemeral conditions. Outliers were identified only for the 15 constituents for which loads were estimated and were only removed from the model calibration datasets for fitting the models and not from other analyses in this report. Possible outliers were first identified by plotting concentrations versus the explanatory variables used in the models $(\ln Q, \ln T$, and doy) and identifying observations that greatly deviate from any observed relations. Consideration for outlier identification was also given to concentrations that did not fit overall patterns with other related constituents, but this assessment requires corroboration with multiple constituents to ensure that the observed concentration was the outlier and not the concentration of the constituent it was plotted against. Groups of constituents where relations might be expected to exist and for which plots were examined include TDS, sonde $\mathrm{SC}$, and lab SC; sediment-related constituents ( $\mathrm{TCd}, \mathrm{TCu}$, $\mathrm{TPb}, \mathrm{TZn}, \mathrm{TOC}, \mathrm{TN}$, and TP), TSS, and SSC; $\mathrm{Ca}$ and $\mathrm{Mg}$; nitrogen constituents ( $\mathrm{TN}, \mathrm{NO}_{3}+\mathrm{NO}_{2}, \mathrm{TKN}$, and $\left.\mathrm{NH}_{3}\right)$; and $\mathrm{TP}$ and DP. Further evidence of an outlier was determined from LOADEST output plots of model residual concentrations versus explanatory variables - these concentrations reflect deviations after accounting for relations with all model explanatory variables at once and more directly indicate possible influences on the model fit. LOADEST also identifies possible outliers by providing the Grubbs and Beck outlier test criteria along with the range of normalized residuals, with outlier residuals falling outside the test criteria range.

When calculating load, if a computational time step was missing streamflow, the daily average streamflow was substituted for the missing value so that a load would be calculated. Using this average daily streamflow is preferable to not calculating that time step's load and using the approach of scaling the annual load estimates to account for the unrepresented runoff, which would be less representative because this, in effect, would apply the average annual load to the missing period. Missing unit-value streamflows occurred infrequently because unit-value streamflow can be estimated when data are missing.

At some watersheds, streamflow monitoring was initiated before water-quality sampling. Loads were estimated by using LOADEST whenever a full calendar year of streamflow was available, even in situations when only one or two waterquality samples were collected for that year. The watersheds in this situation are Shoal Creek for 2012, Snapfinger Creek at Redan Road for 2013, North Fork Peachtree Creek for 2013, and South Fork Peachtree Creek at Casa Drive for 2013. 


\section{Uncertainty Reporting Standards}

In this report, uncertainties of estimation are based on the SEP and are expressed as 95 percent lower and upper confidence intervals. Uncertainties are reported in a probabilistic manner, meaning that the range of values should be reliably within the range of the uncertainties a defined percentage of the time. Uncertainty is also commonly reported as plus or minus one standard error. One should note which reporting standard is being used because the 95 percent confidence interval standard has uncertainty bounds almost twice as large as the plus or minus one standard error standard for the same level of uncertainty. The
95 percent confidence interval standard represents the range of values that should be expected to occur about 95 percent of the time and can be thought of as the range that values are almost certainly to be within. The plus or minus one standard error method represents the range that the values should be within about 68.3 percent of the time and can be thought of as the range that values are merely probable to be within. The SEP is reported in this plus or minus one standard error method. The uncertainties reported are assumed to follow a normal probability distribution in the logarithmic space in which the regression models were developed. As such, the upper 95 percent confidence interval will be larger than the lower 95 percent confidence interval.
Although the calibration dataset does not fully represent the water quality of that year, changes in constituent relations do not change so quickly that extending the model relation to the preceding year would be a problem.

Load is highly dependent on the amount of runoff; hence, large watersheds typically will transport more loads. To better compare loads from different sized watersheds, load was divided by the watershed area to determine yield, which is the load per unit area.

\section{Regression-Model Load Uncertainty Estimates}

Quantifying the uncertainty in the load estimates is important in order to understand whether a difference in load represents a significant difference, such as a change in load, or the difference is within the uncertainty of the estimates. The uncertainty bounds are also a guide to the magnitude of change that is required for a trend to be detected. Uncertainties in the load estimates arise from the accuracy and precision of streamflow measurements, water-quality sample representativeness, laboratory analytical measurements, and load estimation calculations. Horowitz (2003) indicated that suspended-sediment load uncertainties of less than or equal to 15 to 20 percent should be considered relatively accurate for small to large rivers and for load estimates reported for at least quarterly time frames. Uncertainty for dissolved constituents can be more precise if the model explains a large portion of the variance in the data and (or) there is little variance in the data (Aulenbach and others, 2016).

Uncertainty estimates were calculated by using the LOADEST software and are reported for annual loads and yields calculated with this methodology. The standard error of the prediction (SEP) of the mean load estimate is used herein (see the "Uncertainty Reporting Standards" sidebar for more details). The SEP represents the variability attributed to parameter uncertainty of the model calibration and the effects of random error. The SEP calculations assume that the errors are independent in time (no serial correlation) because the presence of serial correlation can result in SEPs underestimating the actual uncertainty in the load estimates (Aulenbach,
2013). Uncertainties are estimated on the basis of how well the load estimation regression model fits the observed data for the conditions observed during the estimation period. Therefore, the size of uncertainty for any given year is not only related to the size of the annual load but is also dependent upon the particular values of the explanatory variables within the estimation dataset for that year.

To assess whether loads, yields, and average annual concentrations are significantly different from each other, both spatially and temporally, connecting letters are provided on the summary plots for these variables (for example, fig. 28). The lack of overlapping 95-percent confidence intervals indicates a significant difference; however, differences can be significant even when there is some overlap of confidence intervals. Goldstein and Healy (1995) indicated that values were significantly different at a $p$-value of 0.05 when confidence intervals of 1.39 standard deviations (about 83-percent confidence intervals) do not overlap. Confidence intervals of this size were calculated from the data's 95-percent confidence intervals, assuming a normal distribution in errors, and overlaps were assessed to generate a connecting letters report. Values that do not share the same letter are significantly different. Letters were generally ordered based on the magnitude of values, from smallest to largest, starting with A. Connecting letters were only determined for values that had uncertainty bounds.

Assessments of uncertainty and potential biases in load estimates are described in the "Assessment of Load Estimation Methodology and Uncertainty" section and in appendix 4. The implications of using the time-step methodology and the benefits of using turbidity as a surrogate model variable are discussed.

Uncertainty estimates are complicated by the fact that some load estimates are a combination of loads from the flow-only and flow-turbidity models. The annual uncertainty in loads of the combined models was estimated by weighting the annual uncertainty of the two models by the fraction of annual runoff each of the models contributed to the annual load. The lower $\left(C I_{95 \% \text { Lower }}\right)$ and upper $\left(C I_{95 \% \text { Upper }}\right) 95$ percent confidence intervals are estimated by using equations 3 and 4 , respectively. 


$$
\begin{aligned}
C I_{95 \% \text { Lower }}= & L_{\text {Total }}-\left[\left(L_{Q T}-C I_{95 \% \text { Lower }(Q T)}\right) * R F_{Q T}\right. \\
& \left.+\left(L_{Q}-C I_{95 \% \text { Lower }(Q)}\right) * R F_{Q}\right] \\
C I_{95 \% \text { Upper }}= & L_{\text {Total }}+\left[\left(C I_{95 \% \text { Upper }(Q T)}-L_{Q T}\right) * R F_{Q T}\right. \\
& \left.+\left(C I_{Q 95 \% \text { Upper }(Q)}-L_{Q}\right) * R F_{Q}\right]
\end{aligned}
$$

where

$L_{\text {Total }} \quad$ is the total annual load;

$L \quad$ is the annual load;

$R F \quad$ is the annual runoff fraction for that model's load; and

$Q T$ and $Q \quad$ represent the flow-turbidity and flow-only models, respectively.

Confidence intervals for yields were then calculated from the load estimate confidence intervals.

Uncertainties for plots showing annual loads for the combined study area and for individual watersheds for the entire study period were calculated by combining the uncertainties from the annual loads. These uncertainties were combined by adding them in quadrature (that is, squared, added, and then taking the square root), which is an appropriate method for combining errors from multiple values (Kirchner, 2001).

\section{Beale Ratio Estimator Methods}

The Beale ratio estimator (BRE) was used to estimate loads for constituents whose concentration models did not explain much of the variance in concentrations $\left(\mathrm{R}^{2}<0.2\right.$, which indicates less than 20 percent of the variance explained) and, therefore, did not warrant using a regression-based load estimation approach. If both flow-only and flow-turbidity models were fit for a constituent, the criteria to use BRE was based on the flow-turbidity model $\mathrm{R}^{2}$ because this is the primary model used for estimating loads with LOADEST. In the BRE method, first the average sample-estimated load is adjusted by the ratio of the average annual flow and the average flow of the samples collected from that year. This load is then corrected for bias by multiplying it by a factor that accounts for the covariance (correlation) between the flow and load values (Beale, 1962). This approach is an unbiased estimator of load when samples are collected randomly. Sampling in this study targeted a minimum of one base-flow and three stormflow samples per 6-month season, so sampling does not represent a fully random approach. BRE loads were estimated on an annual basis by using just the samples collected from that year with a minimum of five sample concentrations required for estimation. Sample stratification with flow or season, which is often used in the BRE approach, was not done because of the small number of samples collected per year. Estimates of uncertainty were not reported for loads using the BRE approach because calculations of error were poor when using small numbers of samples such as herein.

\section{Escherichia coli Bacteria Modeling}

Escherichia coli (E. coli) density models were developed for each of the 15 monitoring sites. These models were used to estimate how frequently the Beach Action Value (BAV) was exceeded at each site and can also be used to predict $E$. coli densities in near real time. The BAV is a tool for making precautionary advisories for primary contact water-based recreational activities, such as swimming and tubing, and is based on analysis of fecal indicator bacteria (FIB) from a single sample (EPA, 2012). FIB are used as a proxy for human health risk from waterborne pathogens. The BAV for freshwater using $E$. coli as the FIB is 235 colony forming units (cfu) per 100 milliliters $(\mathrm{mL})$, corresponding with a risk of gastrointestinal illness rate of 36 per 1,000 primary contact recreators (EPA, 2012). Because it takes time to process and incubate the samples, E. coli results are not available until about 18 or more hours after sampling. Furthermore, short-term increases in bacteria levels associated with stormflow and sanitary sewer overflow events (Gregory and Frick, 2000) are often not representative of the densities observed in infrequently collected discrete samples. The models developed herein can provide more timely notification to recreational users of the potential health risks posed by elevated levels of FIB.

The E. coli models were developed and assessed by using a multiple linear regression approach similar to the approach used for the load estimation models. The logarithm of $E$. coli density was modeled by using a seven-parameter regression model that was a function of the variables streamflow, turbidity, water temperature, and season:

$$
\begin{aligned}
\log (C)= & a_{0}+a_{1} \log (Q)+a_{2} \log (T)+a_{3} \log (W T) \\
& +a_{4} \log (W T)^{2}+a_{5} \sin \theta+a_{6} \cos \theta
\end{aligned}
$$

where

$$
\begin{aligned}
& C \text { is } E \text {. coli density, in colony forming units } \\
& \text { per } 100 \mathrm{~mL} ; \\
& \log \text { is the logarithm function, in base } 10 ; \\
& a_{0} \ldots a_{6} \text { are fitted parameter coefficients; } \\
& Q \text { is instantaneous streamflow, in cubic feet } \\
& \text { per second; } \\
& T \text { is turbidity, in FNU; } \\
& W T \text { is water temperature, in degrees Celsius; and } \\
& \theta \text { is } 2 \pi d o y / 365.25 \text { where doy is day of year. }
\end{aligned}
$$

These explanatory variables have been useful in previous modeling efforts of E. coli densities (Lawrence, 2012; Aulenbach and McKee, 2020). Turbidity is a useful explanatory variable because of the association of $E$. coli with suspended sediments. Fries and others (2006) and Krometis and others (2007) reported that 34 to 42 percent of E. coli in surface-water samples were attached to suspended sediments.

In addition to the model form defined in equation 5, a second model was developed for each site that does not contain the turbidity variable to allow for predictions of $E$. coli when turbidity data are not available, similar to the modeling 
approach used for the load regression models. The Bayesian Information Criteria (BIC; Schwarz, 1978) was used in the forward stepwise regression to determine the optimal set of model parameters. The BIC was used because it selects the model parameters that best explain the inherent variability in the data, whereas the AICc, which was used for the load estimation models, selects the model parameters that best predict its calibration dataset. The BIC is therefore a more appropriate criteria to use in this situation because the developed models may be used in a future predictive manner in addition to predicting the period reflected by the calibration dataset.

Models developed in logarithmic space typically underestimate $E$. coli density because the model fits the geometric mean even though the desired arithmetic mean is higher (Ferguson, 1986). A retransformation bias correction factor was calculated from the nonparametric Duan smearing estimate (Duan, 1983), which is calculated as the mean of the model residuals $(\varepsilon)$ transformed into arithmetic space:

$$
\text { Duan smearing estimate }=\frac{\sum_{i=1}^{n} 10^{\epsilon_{i}}}{n}
$$

where $n$ is the number of observations (sample densities) and $i$ represents the $i$ th number of the sample residual. Model predicted densities were corrected by multiplying the predicted value transformed back into arithmetic space by the Duan smearing estimate.

\section{Watershed Relations Among Watershed Characteristics, Runoff Metrics, and Yields}

Relations between selected variables across the study watersheds were determined to better understand interactions between various runoff metrics and identify possible effects of watershed characteristics on runoff metrics and constituent yields. Relations do not necessarily indicate cause and effect. Similarities can be incidental or the result of a common third variable, and relations can be obscured because of the complex interactions of multiple variables, including some that have not been assessed. Linear relations were quantified by using the Pearson product-moment correlation coefficient $(r)$. Correlation coefficients can vary from -1 to 1 , with values near zero indicating low correlation and values near \pm 1 indicating high correlation. The strengths of the correlations are qualified herein based on the magnitude of $r$ as very weak to none $(<0.3)$, weak $(\geq 0.3$ to $<0.5)$, moderate $(\geq 0.5$ to $<0.7)$, strong $(\geq 0.7$ to $<0.9)$, and very strong $(\geq 0.9)$.

\section{Watershed Characteristics}

Watershed characteristics were determined for the 15 study watersheds, including drainage areas, land-surface elevations, land-surface slopes, land use, percentage of impervious areas, and population densities. Basin characteristics, such as geology, drainage networks, land-surface elevations and slopes, and land use can all affect surfacewater quantity and quality. In particular, higher proportions of impervious area associated with urbanization often result in increased storm runoff and decreased base flow. Watershed characteristics are later compared to watershed runoff characteristics and water quality, providing insight into possible reasons for variations in runoff and water quality between watersheds.

\section{Topography}

Land-surface topography affects hydrology and water quality because it defines basin drainage networks that generate and transport stream runoff. Steeper land-surface slopes are associated with higher surface runoff and erosion, and land-surface elevations and configurations can affect the distribution of precipitation. Land-surface elevations within the study area range from $718 \mathrm{ft}$ (South River watershed) to $1,683 \mathrm{ft}$ (Stone Mountain Creek watershed) above North American Vertical Datum of 1988 (NAVD 88; fig. 3; table 7). The Stone Mountain Creek watershed has a much higher maximum elevation than the other watersheds because of the 825-ft-tall Stone Mountain monadnock within it. The maximum elevation within the other watersheds is $1,185 \mathrm{ft}$ above NAVD 88 (Nancy Creek watershed). Lower elevations are within DeKalb County downstream of the monitored watersheds, mostly along the South River. Average land-surface elevations for the watersheds range from $840 \mathrm{ft}$ (Pole Bridge Creek watershed) to $1,038 \mathrm{ft}$ (South Fork Peachtree Creek at Casa Drive watershed) above NAVD 88. Average elevations are higher in the smaller, more upstream watersheds and are generally higher in the northern part of the county within the Chattahoochee River Basin. The Stone Mountain Creek watershed has a range in elevations of $945 \mathrm{ft}$, whereas the other watersheds have ranges between $138 \mathrm{ft}$ (Burnt Fork Creek watershed) and $394 \mathrm{ft}$ (South River watershed). Elevation range is generally larger for watersheds with larger drainage areas - with the exception of the Stone Mountain Creek watershed, the range of which is primarily the result of the presence of Stone Mountain.

Land-surface slopes are variable with more widespread, steeper slopes present in the Intrenchment Creek, South River, Stone Mountain Creek, North Fork Peachtree Creek, the downstream (western) portion of the South Fork Peachtree Creek at Johnson Road, and Nancy Creek watersheds (fig. 4). Average land-surface slopes in 14 of the watersheds range from 6.5 percent (South Fork Peachtree Creek at Casa Drive watershed) to 9.3 percent (Little Stone Mountain Creek and South Fork Peachtree Creek at Johnson Road watersheds), and the average land-surface slope for the Stone Mountain Creek watershed is 10.3 percent, which contains steeply-sided Stone Mountain (fig. 5). Watersheds in the South River Basin have more similar average land-surface slopes, but watersheds in 
Table 7. Watershed characteristics for 15 watersheds in DeKalb County, Georgia.

[NAVD 88, North American Vertical Datum of 1988; na, not applicable]

\begin{tabular}{|c|c|c|c|c|c|c|c|c|c|}
\hline \multirow[b]{2}{*}{ Watershed } & \multicolumn{3}{|c|}{ Drainage area } & \multicolumn{4}{|c|}{ Elevation (feet above NAVD 88) } & \multirow[b]{2}{*}{$\begin{array}{c}\text { Average land- } \\
\text { surface slope, } \\
\text { in percent }\end{array}$} & \multirow[b]{2}{*}{$\begin{array}{l}\text { Topographic } \\
\text { wetness index }\end{array}$} \\
\hline & $\begin{array}{c}\text { (square } \\
\text { miles) }\end{array}$ & $\begin{array}{l}\text { Area within } \\
\text { DeKalb County } \\
\text { (square miles) }\end{array}$ & $\begin{array}{l}\text { Percentage of } \\
\text { study area }\end{array}$ & Minimum & Maximum & Range & Average & & \\
\hline Doolittle Creek & 4.16 & 4.16 & 1.62 & 793 & 1,060 & 267 & 961 & 8.2 & 8.6 \\
\hline Shoal Creek & 8.63 & 8.63 & 3.37 & 749 & 1,080 & 330 & 943 & 8.4 & 8.6 \\
\hline Cobbs Creek & 7.97 & 7.97 & 3.11 & 782 & 1,084 & 303 & 932 & 8.1 & 8.6 \\
\hline Snapfinger Creek at Thompson Mill Road & 32.55 & 32.55 & 12.70 & 751 & 1,032 & 280 & 887 & 8.1 & 8.6 \\
\hline Pole Bridge Creek & 16.06 & 16.06 & 6.27 & 724 & 1,010 & 285 & 840 & 7.7 & 8.6 \\
\hline Little Stone Mountain Creek & 2.19 & 1.61 & 0.86 & 873 & 1,119 & 246 & 1,001 & 9.3 & 8.6 \\
\hline Stone Mountain Creek & 28.08 & 25.71 & 10.96 & 738 & 1,683 & 945 & 911 & 10.3 & 8.6 \\
\hline North Fork Peachtree Creek & 34.16 & 29.33 & 13.33 & 811 & 1,129 & 318 & 966 & 9.0 & 8.6 \\
\hline $\begin{array}{l}\text { South Fork Peachtree Creek at Casa } \\
\text { Drive }\end{array}$ & 5.67 & 5.67 & 2.21 & 938 & 1,126 & 188 & 1,038 & 6.5 & 8.5 \\
\hline Nancy Creek & 17.79 & 15.93 & 6.94 & 842 & 1,158 & 316 & 995 & 8.8 & 8.6 \\
\hline Study watersheds & 256.27 & 205.42 & 100 & 718 & 1,683 & 965 & 916 & 8.7 & 8.6 \\
\hline DeKalb County & 271.17 & na & na & 518 & 1,683 & 1,165 & 919 & 9.0 & 8.6 \\
\hline
\end{tabular}




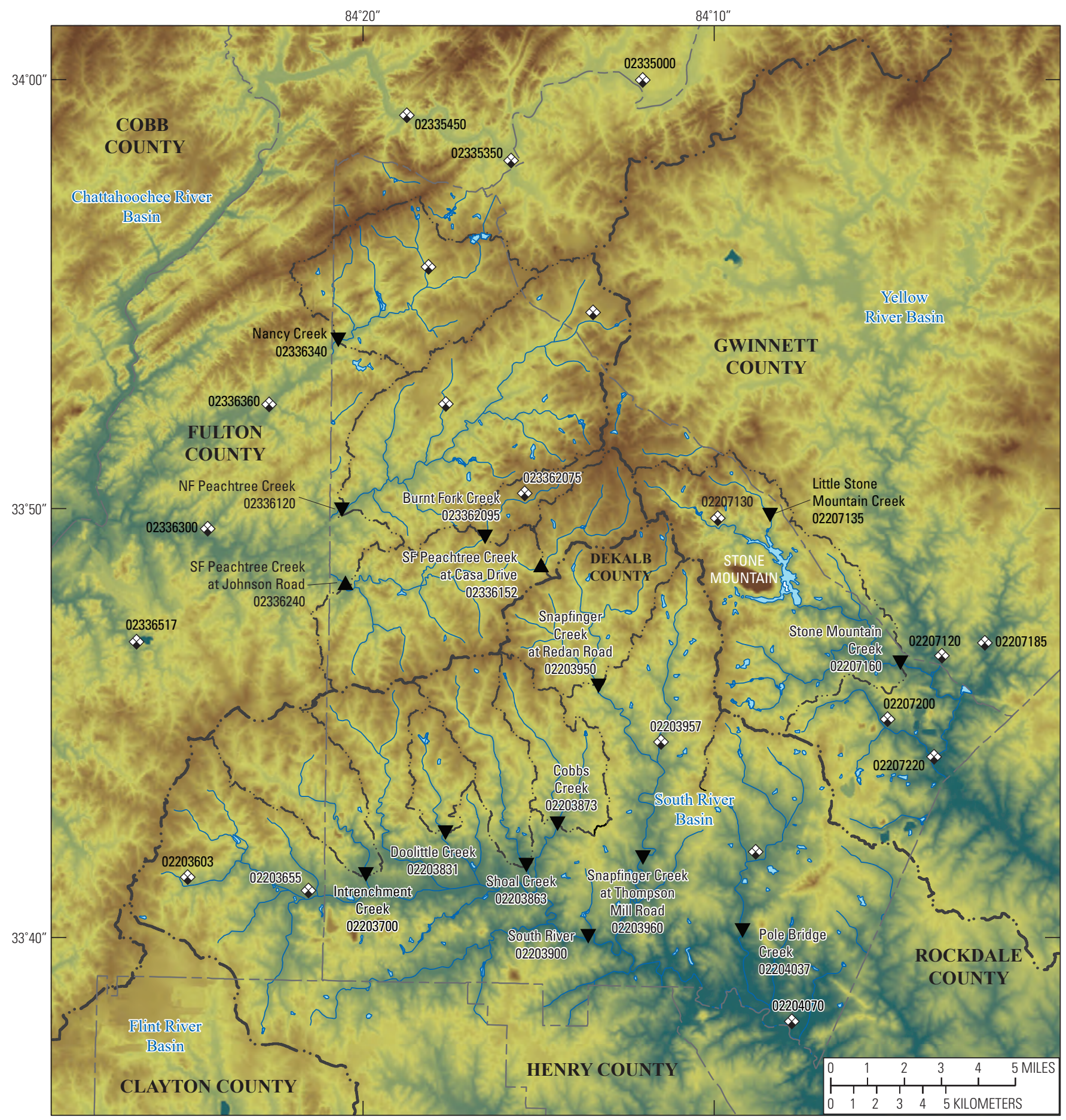

Base modified from U.S. Geological Survey (USGS) 1:100,000-scale digital data Land-surface elevations from the USGS 3D Elevation Program (USGS, 2017) Hydrologic data from the National Hydrography Dataset (USGS, 2021a)

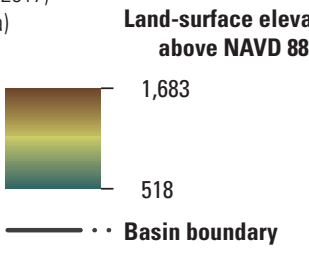

in feet

EXPLANATION
SF Peachtree Creek at Johnson Road 02336240

\section{Monitored watershed boundary}

USGS streamflow, water-quality, and precipitation monitoring site with site name and identifier (see tables 1 and 6)

USGS precipitation-only monitoring site and identifier (see table 6)

USGS streamflow and water-quality monitoring site with site name and identifier (see tables 1 and 6)

Figure 3. Land-surface elevation for DeKalb County, Georgia. Abbreviations: NF, Forth Fork; SF, South Fork. 
the Chattahoochee River Basin have more variable average land-surface slopes. Topographic wetness indexes were similar for all watersheds, likely because of the small range in watershed average land-surface slopes (table 7).

\section{Land Use and Imperviousness}

In 2012, the study watersheds were dominated by medium-density residential (43.9 percent) and commercial/industrial/institutional (21.4 percent) land uses; forest/ park/agriculture (13.6 percent) and high-density residential (11.5 percent) also constituted substantial proportions of the land use (Atlanta Regional Commission, 2012; table 8). DeKalb County, as a whole, had somewhat lower proportions of commercial/industrial/institutional and high-density residential land uses and higher proportions of forest/park/agriculture land uses than for the study watersheds (table 9). Most of the land in the watersheds was used for residential areas, ranging from 47.8 to 95.5 percent for the Intrenchment Creek and Little Stone Mountain Creek watersheds, respectively. The predominance of developed land use types and lack of large proportions of forests, agricultural lands, and parks are typical of well-developed suburban and urban areas.

The highest proportions of commercial/industrial/ institutional land use in 2012 were in the Burnt Fork Creek (40.9 percent) and Nancy Creek (34.8 percent) watersheds (fig. 6; table 9). The Intrenchment Creek watershed had the highest proportion of high-density residential (29.9 percent) and the lowest proportion of medium-density residential (17.6 percent) and overall residential (47.8 percent) land uses because the City of Atlanta covers 71.3 percent of that watershed. The Little Stone Mountain Creek watershed is small and was made up of almost exclusively medium-density residential (95.5 percent). The Doolittle Creek and Cobbs Creek watersheds also had high proportions (69.2 and 64.1 percent, respectively) of medium-density residential land use. The proportions of medium-density residential land use for the other 11 watersheds ranged from 36.9 to 58.5 percent for the South River and Shoal Creek watersheds, respectively. The highest proportion of forest/park/agriculture land use was in the Stone Mountain Creek watershed (29.9 percent); 17.8 percent of this watershed is composed of Stone Mountain State Memorial Park. Forest/park/agriculture land use was also high in the Pole Bridge Creek (19.5 percent) and South River watersheds (14.8 percent). The Intrenchment Creek watershed had a much higher proportion of landfill/other land use (8.79 percent) than the other watersheds because it contains a large landfill and many of the other urban land uses included in this land use group.

Imperviousness was 25.3 percent in the study watersheds and 22.9 percent in DeKalb County (fig. 7). Imperviousness in the study watersheds ranged from 8.7 percent (Little Stone Mountain Creek watershed) to 36.6 percent (Burnt Fork Creek watershed). The imperviousness of a watershed reflects the proportions of various land use groups within the watershed because each land use group has its own distinct level of imperviousness (table 8). Of the four largest land use groups that represent 90.3 percent of the study area, the commercial/ industrial/institutional and high-density residential land use groups had the highest imperviousness (55.2 and 32.7 percent, respectively); the medium-density residential land use group had a moderate but below average imperviousness (14.8 percent); and the forest/park/agriculture land use group had a very low percentage of imperviousness ( 4.9 percent). The three watersheds with the highest imperviousness were the Burnt Fork Creek watershed, which had the highest proportion of commercial/industrial/institutional land use (40.9 percent); the Intrenchment Creek watershed, which had the highest proportion of high-density residential land use (29.9 percent); and the Nancy Creek watershed, which had a high proportion of both commercial/industrial/institutional (34.8 percent) and high-density residential (11.8 percent) land use groups (tables 9 and 10). Imperviousness was lowest in the Little Stone Mountain Creek watershed, which had the highest proportion of medium-density residential land use ( 95.5 percent), and the Stone Mountain Creek watershed, which had the highest proportion of Forest/Park/Agricultural land use (29.9 percent).

Watershed imperviousness was significantly corre-

lated with many of the land uses in the watershed (table 8). Imperviousness had a very strong positive correlation with the commercial/industrial/institutional group $(r=0.945)$, a strong positive correlation with the transportation/communication/ utilities group $(r=0.704)$, a moderate positive correlation with the high-density residential group $(r=0.602)$, and a strong negative correlation with the medium-density residential group $(r=-0.705)$. These stronger correlations highlight the land use groups that were most influential on imperviousness in the study watersheds. The medium-density residential group had a negative correlation because this group had a lower percent imperviousness than the overall study area. Weaker correlations are associated with land use groups that compose smaller watershed areas and (or) were more similar to the percent imperviousness of the study area and were not statistically significant at a $p$-value of 0.05 .

\section{Population}

Population density averaged 2,936 people per square mile in the study area. Population densities were generally highest in the western and central parts of the county, which are closer to the center of the City of Atlanta (fig. 8). Average watershed population densities ranged from 1,208 to 4,457 people per square mile (fig. 9). Population densities were highest in the Snapfinger Creek at Redan Road, Snapfinger Creek at Thompson Mill Road, North Fork Peachtree Creek, Intrenchment Creek, and South Fork Peachtree Creek at Johnson Road watersheds, which contain widespread residential and (or) high-density residential land use (fig. 6). The upper reaches of the Intrenchment Creek watershed drain a portion of the City of Atlanta that includes 


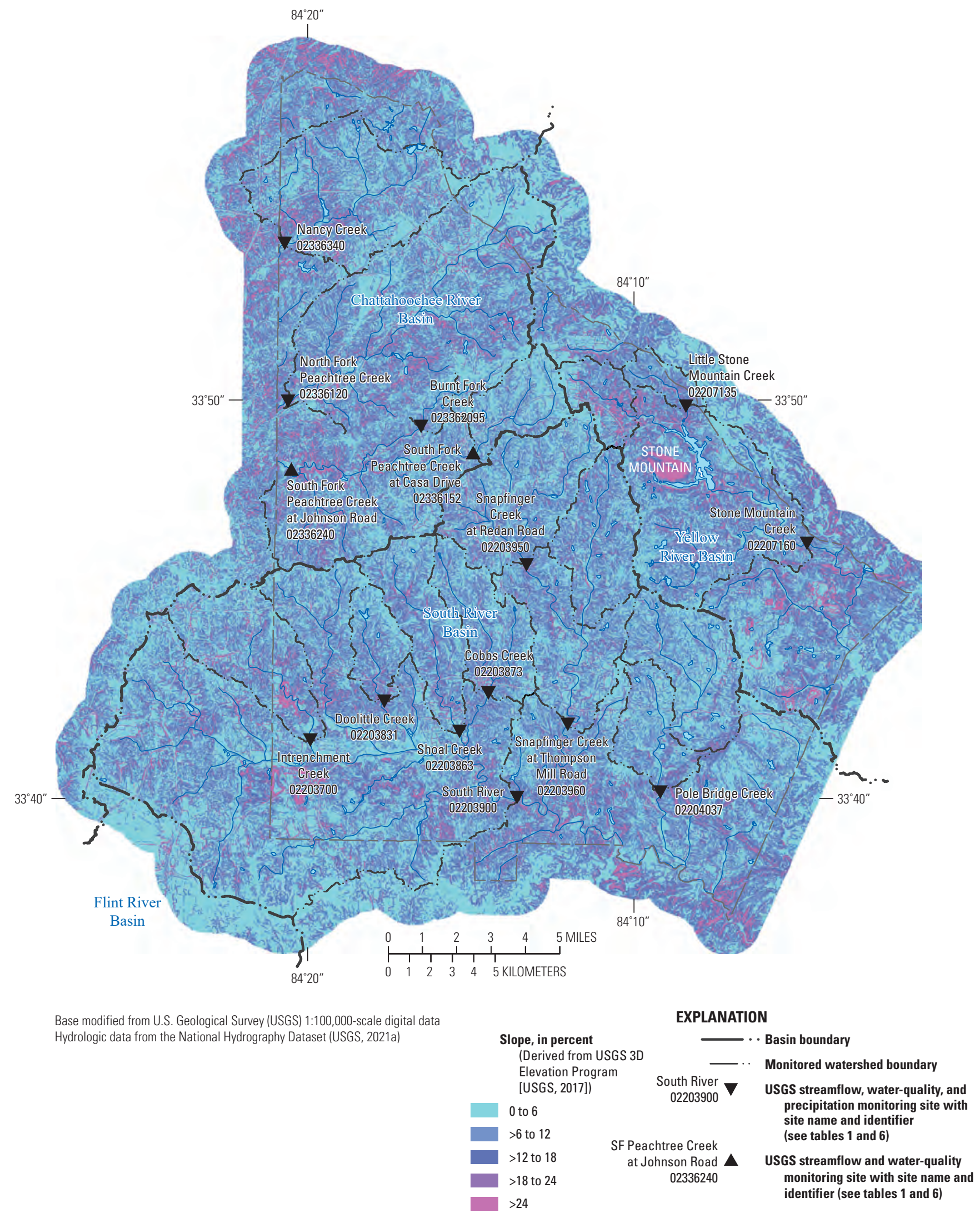

Figure 4. Land-surface slope for DeKalb County, Georgia. 


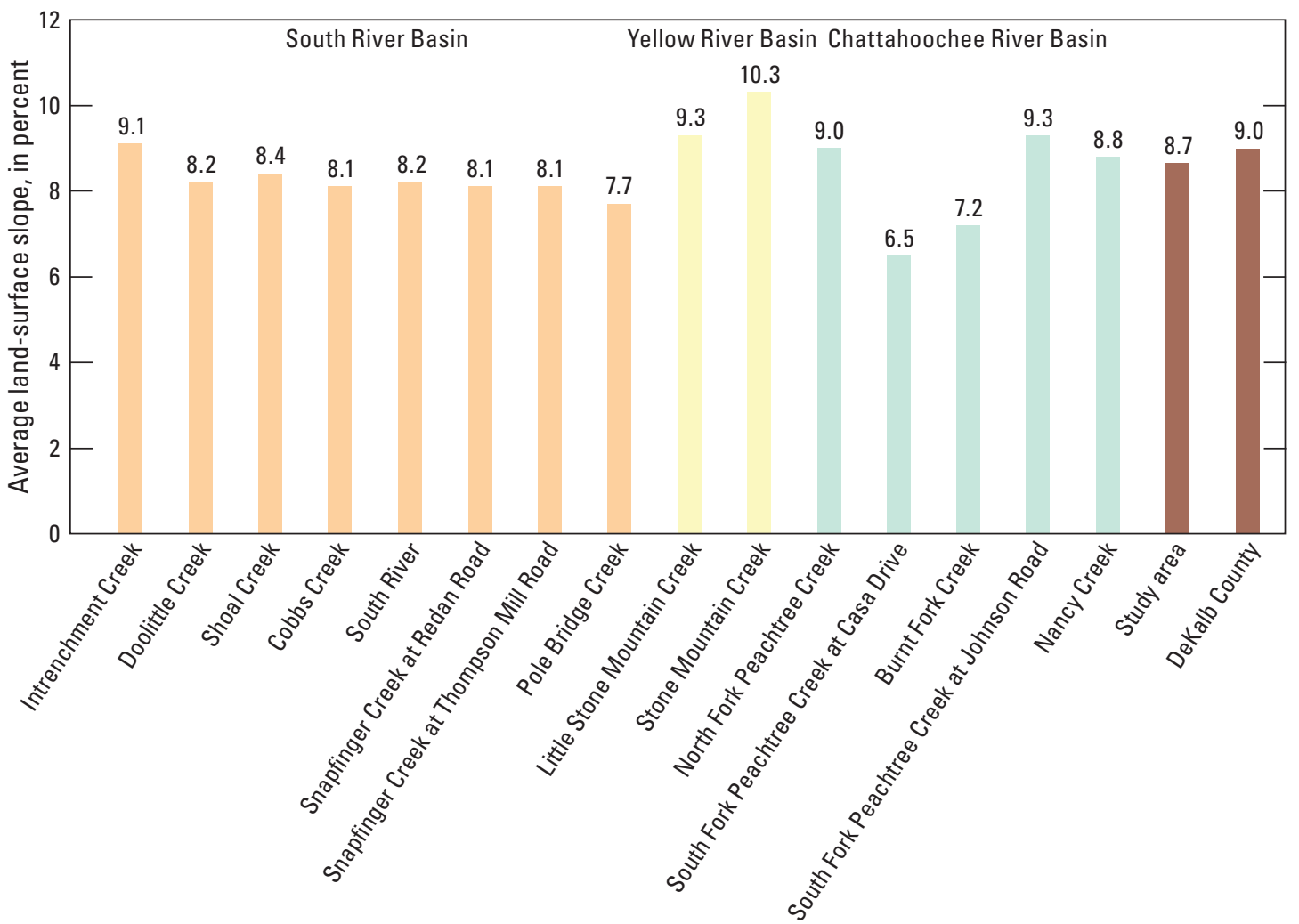

Watershed

Figure 5. Average land-surface slope for the 15 monitored watersheds in DeKalb County, Georgia. Elevation data derived from the U.S. Geological Survey 3D Elevation Program (U.S. Geological Survey, 2017).

Table 8. Land use groups in the study watersheds for 2012, average percent developed imperviousness for 2011, and correlations between watershed land use group fractional area and imperviousness.

[Land use derived from the Atlanta Regional Commission LandPro 2012 land use dataset (Atlanta Regional Commission, 2012). Percent developed imperviousness derived from the National Land Cover Database 2011 dataset (U.S. Geological Survey, 2011); <, less than]

\begin{tabular}{|c|c|c|c|c|}
\hline $\begin{array}{l}\text { Land use group } \\
\text { (table 2) }\end{array}$ & $\begin{array}{l}\text { Percentage of } \\
\text { area in study } \\
\text { watersheds }\end{array}$ & $\begin{array}{c}\text { Average percent } \\
\text { developed } \\
\text { imperviousness }\end{array}$ & $\begin{array}{l}\text { Correlation coef- } \\
\text { ficient between } \\
\text { watershed land use } \\
\text { group percentage } \\
\text { of area and percent } \\
\text { developed } \\
\text { imperviousness }\end{array}$ & $\begin{array}{l}p \text {-value of } \\
\text { correlation } \\
\text { coefficient }\end{array}$ \\
\hline High-density residential & 11.5 & 32.7 & 0.602 & 0.018 \\
\hline Medium-density residential & 43.9 & 14.8 & -0.705 & 0.003 \\
\hline Low-density residential & 2.0 & 6.6 & -0.337 & 0.22 \\
\hline Forest/park/agriculture & 13.6 & 4.9 & -0.455 & 0.089 \\
\hline
\end{tabular}


Table 9. Land use group (table 2) percentages in 15 watersheds in DeKalb County, Georgia, 2012.

[All values are percentages unless otherwise noted; Land use data are derived from the Atlanta Regional Commission LandPro 2012 land use dataset (Atlanta Regional Commission, 2012)]

\begin{tabular}{|c|c|c|c|c|c|c|c|c|c|}
\hline Watershed & $\begin{array}{l}\text { Drainage } \\
\text { area } \\
\text { (square } \\
\text { miles) }\end{array}$ & $\begin{array}{l}\text { Commercial/ } \\
\text { industrial/ } \\
\text { institutional }\end{array}$ & $\begin{array}{c}\text { Transportation/ } \\
\text { communication/ } \\
\text { utilities }\end{array}$ & $\begin{array}{l}\text { High-density } \\
\text { residential }\end{array}$ & $\begin{array}{l}\text { Medium- } \\
\text { density } \\
\text { residential }\end{array}$ & $\begin{array}{l}\text { Low-density } \\
\text { residential }\end{array}$ & $\begin{array}{c}\text { Forest/ } \\
\text { park/ } \\
\text { agriculture }\end{array}$ & $\begin{array}{c}\text { Water/ } \\
\text { wetlands }\end{array}$ & $\begin{array}{l}\text { Landfills/ } \\
\text { other }\end{array}$ \\
\hline Intrenchment Creek & 10.76 & 26.0 & 8.76 & 29.9 & 17.6 & 0.40 & 8.51 & 0.11 & 8.79 \\
\hline Doolittle Creek & 4.16 & 11.2 & 4.19 & 2.60 & 69.2 & 0.00 & 11.3 & 1.16 & 0.33 \\
\hline Shoal Creek & 8.63 & 19.3 & 2.05 & 10.0 & 58.5 & 0.46 & 9.08 & 0.15 & 0.44 \\
\hline Cobbs Creek & 7.97 & 14.4 & 6.03 & 6.05 & 64.1 & 1.19 & 8.02 & 0.00 & 0.17 \\
\hline South River & 100.01 & 22.6 & 6.02 & 13.3 & 36.9 & 1.76 & 14.8 & 1.00 & 3.60 \\
\hline Snapfinger Creek at Redan Road & 13.15 & 22.7 & 3.26 & 17.4 & 49.0 & 0.00 & 6.79 & 0.35 & 0.50 \\
\hline $\begin{array}{l}\text { Snapfinger Creek at Thompson Mill } \\
\text { Road }\end{array}$ & 32.55 & 16.0 & 3.07 & 12.7 & 55.2 & 0.52 & 11.4 & 0.69 & 0.27 \\
\hline Pole Bridge Creek & 16.06 & 17.9 & 5.70 & 11.4 & 37.3 & 5.70 & 19.5 & 1.78 & 0.79 \\
\hline Little Stone Mountain Creek & 2.19 & 0.36 & 0.02 & 0.00 & 95.5 & 0.00 & 4.13 & 0.00 & 0.00 \\
\hline Stone Mountain Creek & 28.08 & 8.89 & 3.43 & 1.14 & 47.9 & 6.56 & 29.9 & 1.95 & 0.29 \\
\hline North Fork Peachtree Creek & 34.16 & 25.7 & 6.47 & 13.1 & 50.4 & 0.00 & 3.54 & 0.34 & 0.39 \\
\hline $\begin{array}{l}\text { South Fork Peachtree Creek at Casa } \\
\text { Drive }\end{array}$ & 5.67 & 26.3 & 4.42 & 13.8 & 45.6 & 0.00 & 9.67 & 0.17 & 0.00 \\
\hline Burnt Fork Creek & 3.25 & 40.9 & 4.03 & 3.11 & 49.6 & 0.00 & 2.36 & 0.00 & 0.00 \\
\hline $\begin{array}{l}\text { South Fork Peachtree Creek at Johnson } \\
\text { Road }\end{array}$ & 27.62 & 23.8 & 3.76 & 12.2 & 49.1 & 0.94 & 9.77 & 0.33 & 0.08 \\
\hline Nancy Creek & 17.79 & 34.8 & 6.54 & 11.8 & 41.3 & 1.02 & 4.32 & 0.20 & 0.00 \\
\hline Study watersheds & 256.27 & 21.4 & 5.19 & 11.5 & 43.9 & 2.00 & 13.6 & 0.90 & 1.58 \\
\hline DeKalb County & 271.17 & 17.0 & 4.80 & 7.51 & 46.6 & 3.22 & 18.0 & 1.20 & 1.71 \\
\hline
\end{tabular}




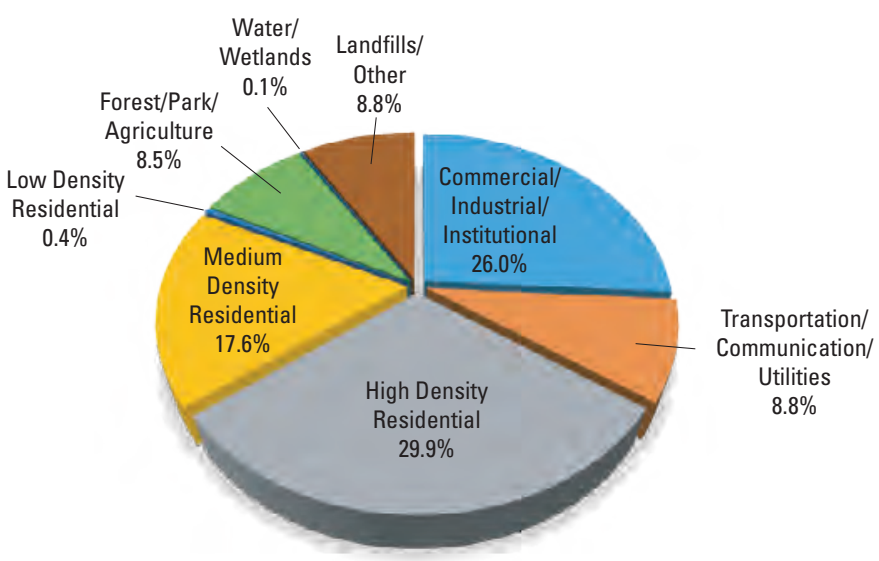

Intrenchment Creek

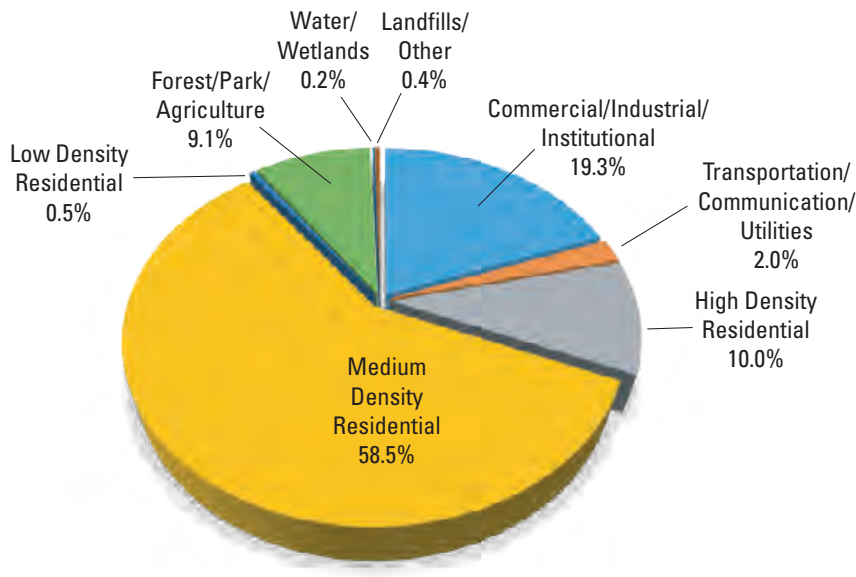

Shoal Creek

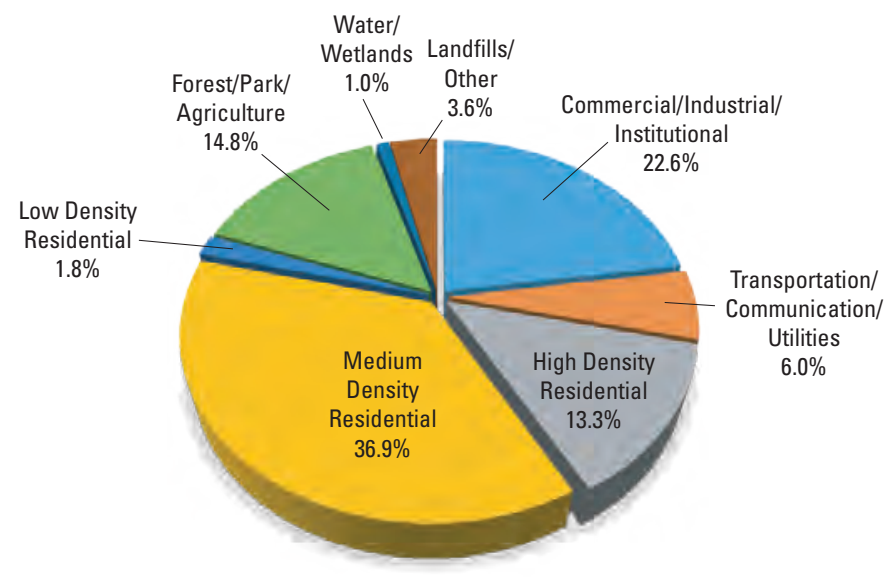

South River

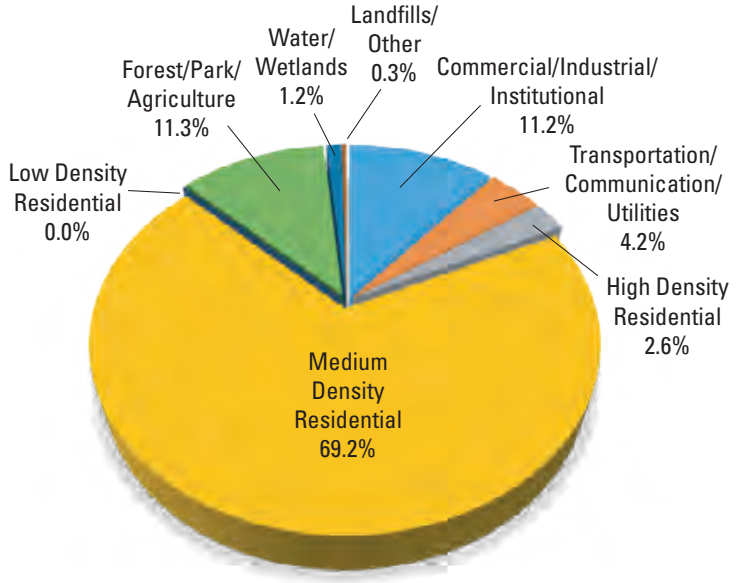

Doolittle Creek

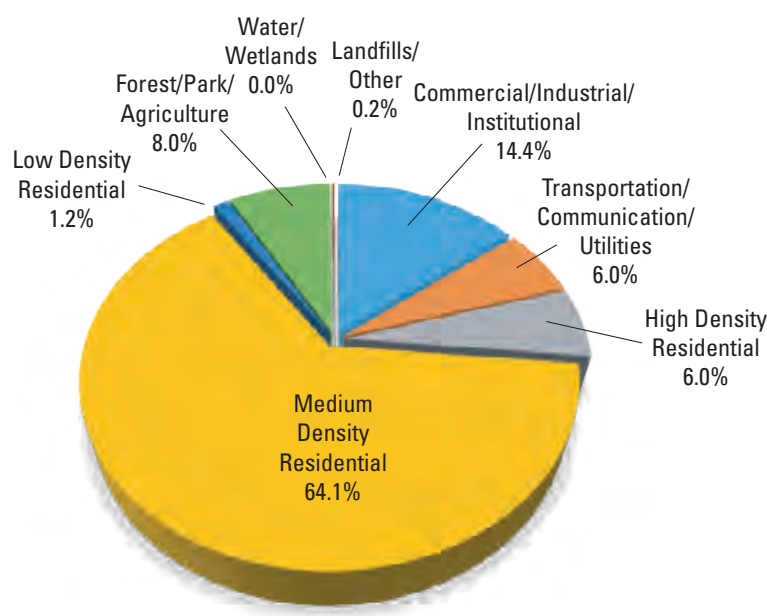

Cobbs Creek

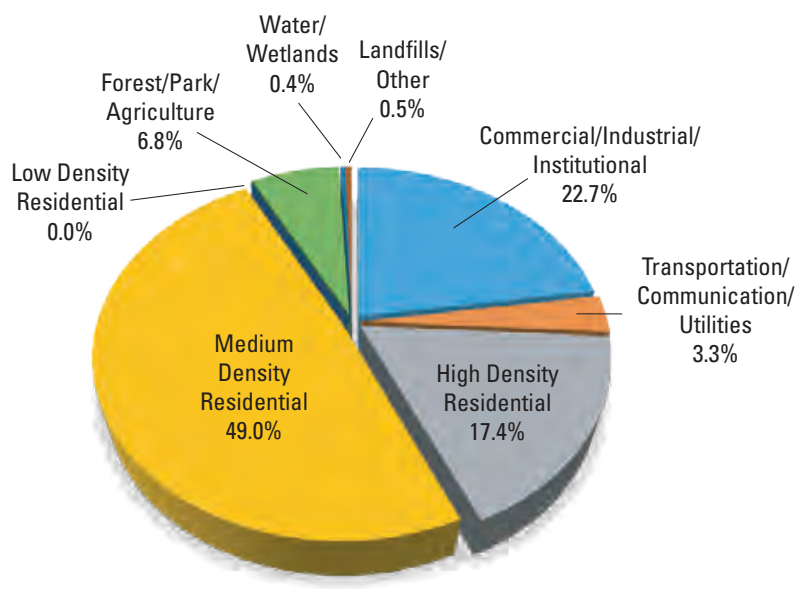

Snapfinger Creek at Redan Road

Figure 6. Percentage of each land use group within each of the 15 monitored watersheds, the watersheds study area, and DeKalb County, Georgia. Land use data derived from the Atlanta Regional Commission LandPro 2012 land use dataset (Atlanta Regional Commission, 2012). Abbreviation: \%, percent. 


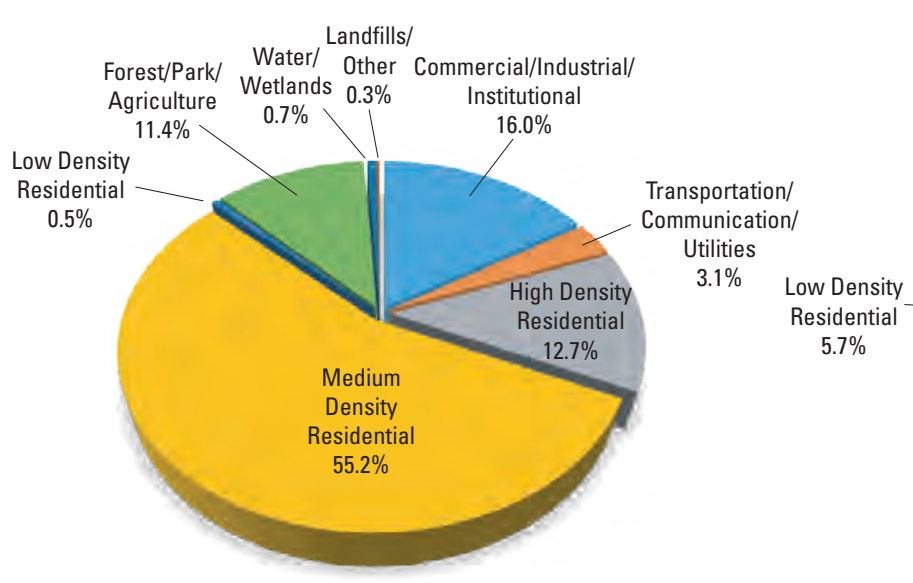

Snapfinger Creek at Thompson Mill Road

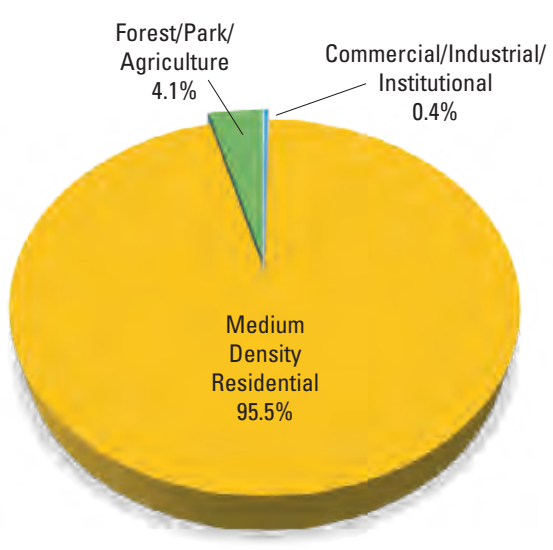

Little Stone Mountain Creek

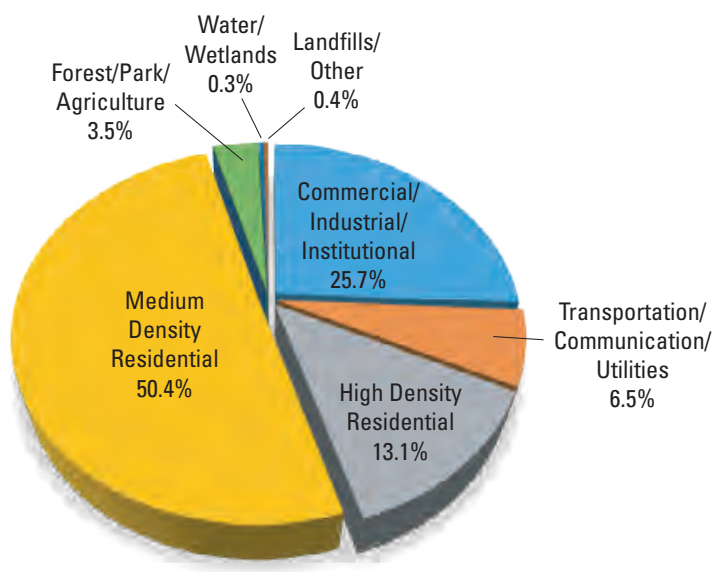

North Fork Peachtree Creek

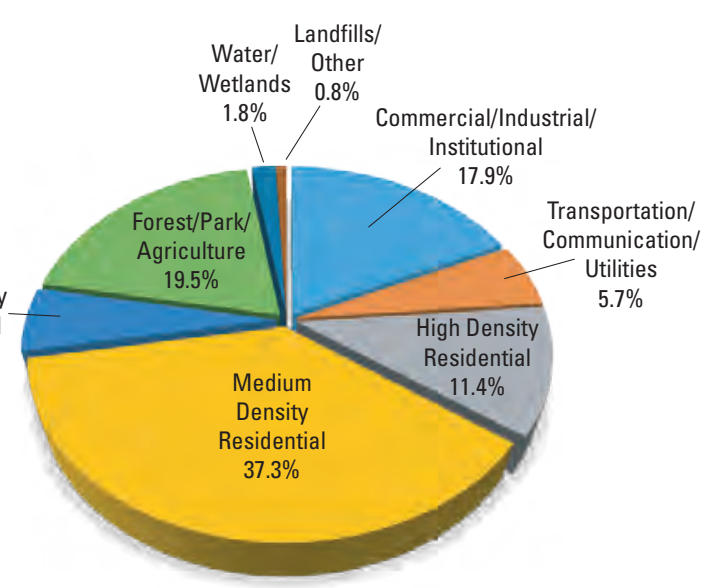

Pole Bridge Creek

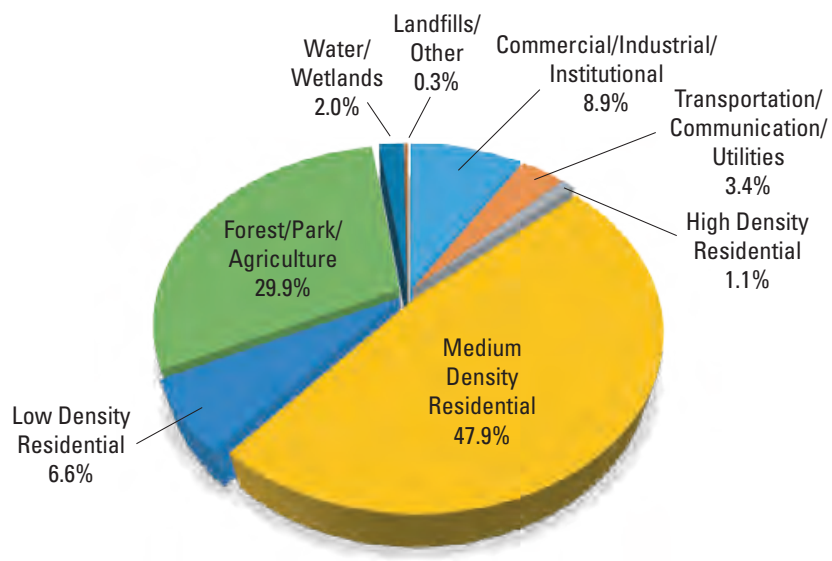

Stone Mountain Creek

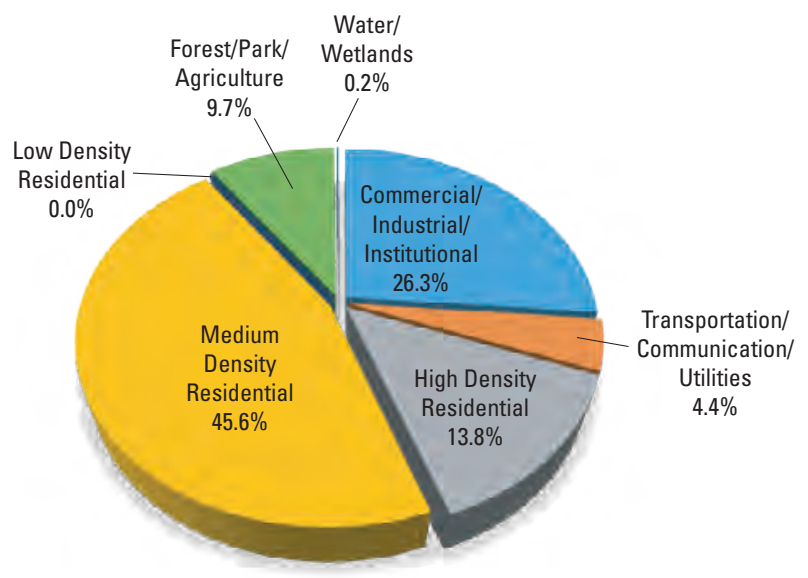

South Fork Peachtree Creek at Casa Drive

Figure 6. Percentage of each land use group within each of the 15 monitored watersheds, the watersheds study area, and DeKalb County, Georgia. Land use data derived from the Atlanta Regional Commission LandPro 2012 land use dataset (Atlanta Regional Commission, 2012). Abbreviation: \%, percent.-Continued 

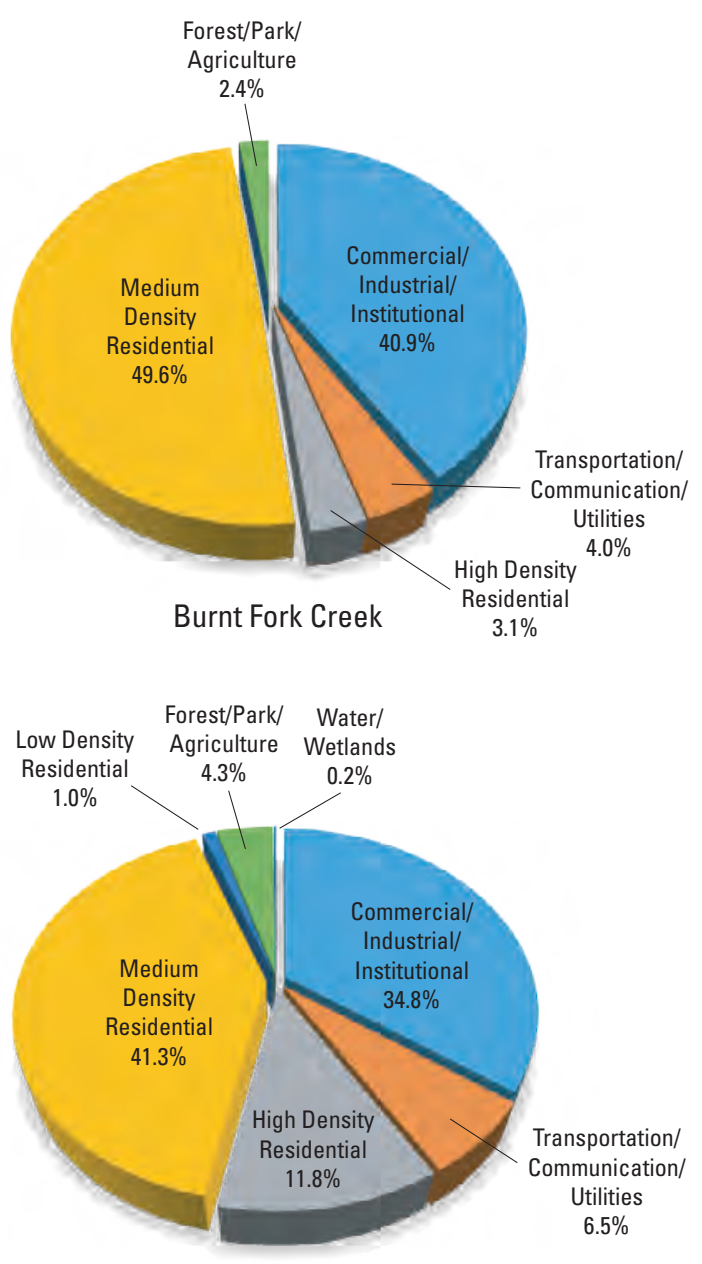

Nancy Creek

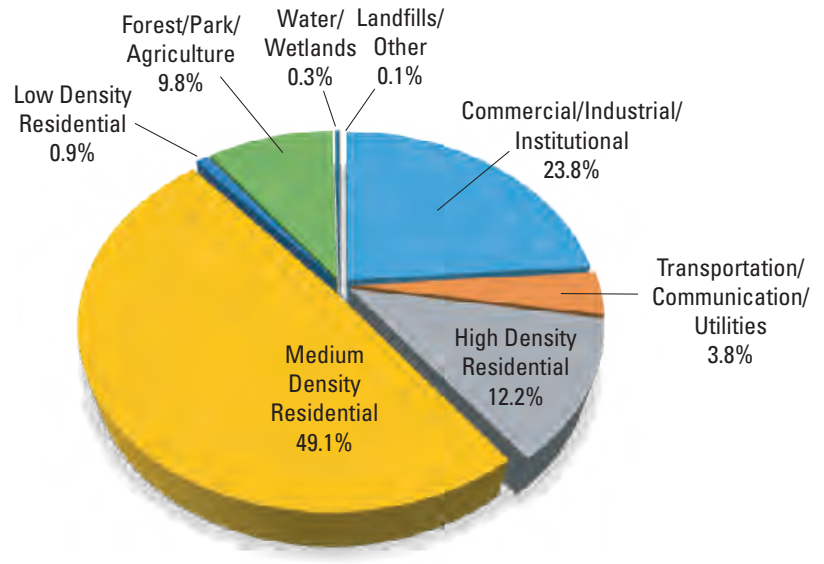

South Fork Peachtree Creek at Johnson Road

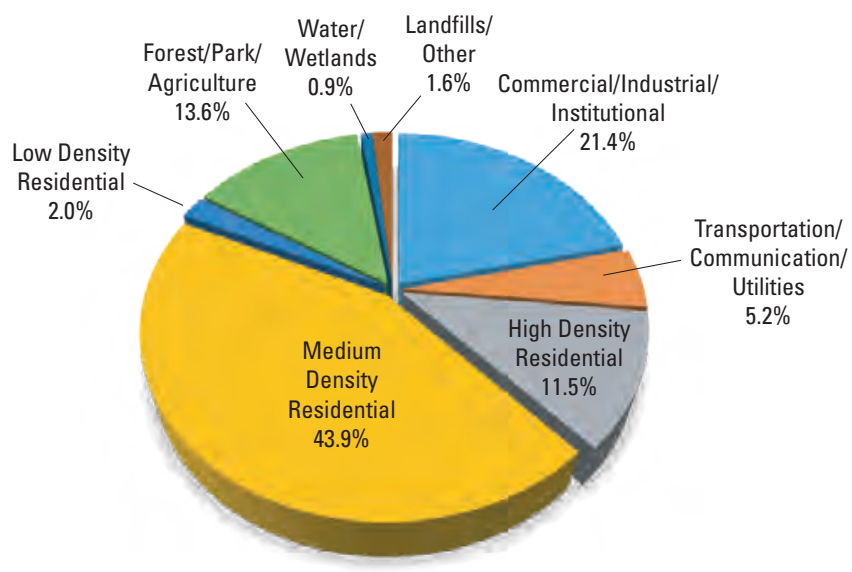

Study watersheds

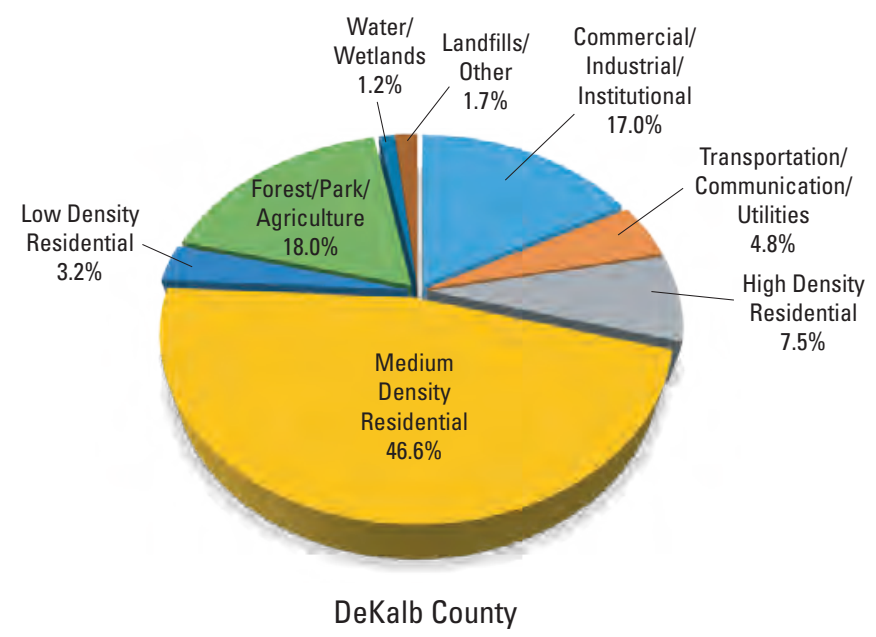

Figure 6. Percentage of each land use group within each of the 15 monitored watersheds, the watersheds study area, and DeKalb County, Georgia. Land use data derived from the Atlanta Regional Commission LandPro 2012 land use dataset (Atlanta Regional Commission, 2012). Abbreviation: \%, percent.-Continued 
Table 10. Percent developed imperviousness within the 15 monitored watersheds in DeKalb County, Georgia, 2011.

[ft, foot; Land use data derived from the National Land Cover Database (NLCD) 2011 dataset (U.S. Geological Survey, 2011)]

\begin{tabular}{|c|c|c|c|}
\hline Watershed & $\begin{array}{l}\text { Percent developed } \\
\text { imperviousness }\end{array}$ & $\begin{array}{l}\text { Percent developed } \\
\text { imperviousness within } \\
100 \text {-ft stream buffer }\end{array}$ & $\begin{array}{l}\text { Percent developed } \\
\text { imperviousness within } \\
200 \text {-ft stream buffer }\end{array}$ \\
\hline Intrenchment Creek & 36.0 & 7.9 & 10.1 \\
\hline Doolittle Creek & 18.5 & 6.5 & 8.5 \\
\hline Shoal Creek & 20.7 & 6.5 & 8.8 \\
\hline Cobbs Creek & 22.3 & 6.4 & 8.8 \\
\hline Snapfinger Creek at Redan Road & 26.0 & 12.5 & 14.9 \\
\hline Snapfinger Creek at Thompson Mill Road & 21.0 & 7.8 & 9.7 \\
\hline Pole Bridge Creek & 21.6 & 5.8 & 8.7 \\
\hline Little Stone Mountain Creek & 8.7 & 0.65 & 1.6 \\
\hline Burnt Fork Creek & 36.6 & 20.0 & 22.3 \\
\hline South Fork Peachtree Creek at Johnson Road & 26.3 & 9.9 & 12.8 \\
\hline Nancy Creek & 34.9 & 14.4 & 17.7 \\
\hline Study watersheds & 25.3 & 8.7 & 11.3 \\
\hline
\end{tabular}

a substantial percentage of high-density residential land use. The Snapfinger Creek watersheds include residential areas along the Interstate 285 corridor. The North Fork Peachtree Creek watershed includes residential areas along the Interstate 85 corridor including the North Druid Hills neighborhood. The South Fork Peachtree Creek at Johnson Road watershed includes portions of the City of Decatur and several adjacent residential communities. Population densities were lowest in the Little Stone Mountain Creek, Stone Mountain Creek, and Burnt Fork Creek watersheds. The Little Stone Mountain Creek watershed contains a lower density residential community (Smoke Rise) and forested land use. The Stone Mountain Creek watershed contains Stone Mountain State Memorial Park which takes up a large portion of that watershed. The Burnt Fork Creek watershed has a large proportion of commercial retail and industrial areas relative to residential areas. 


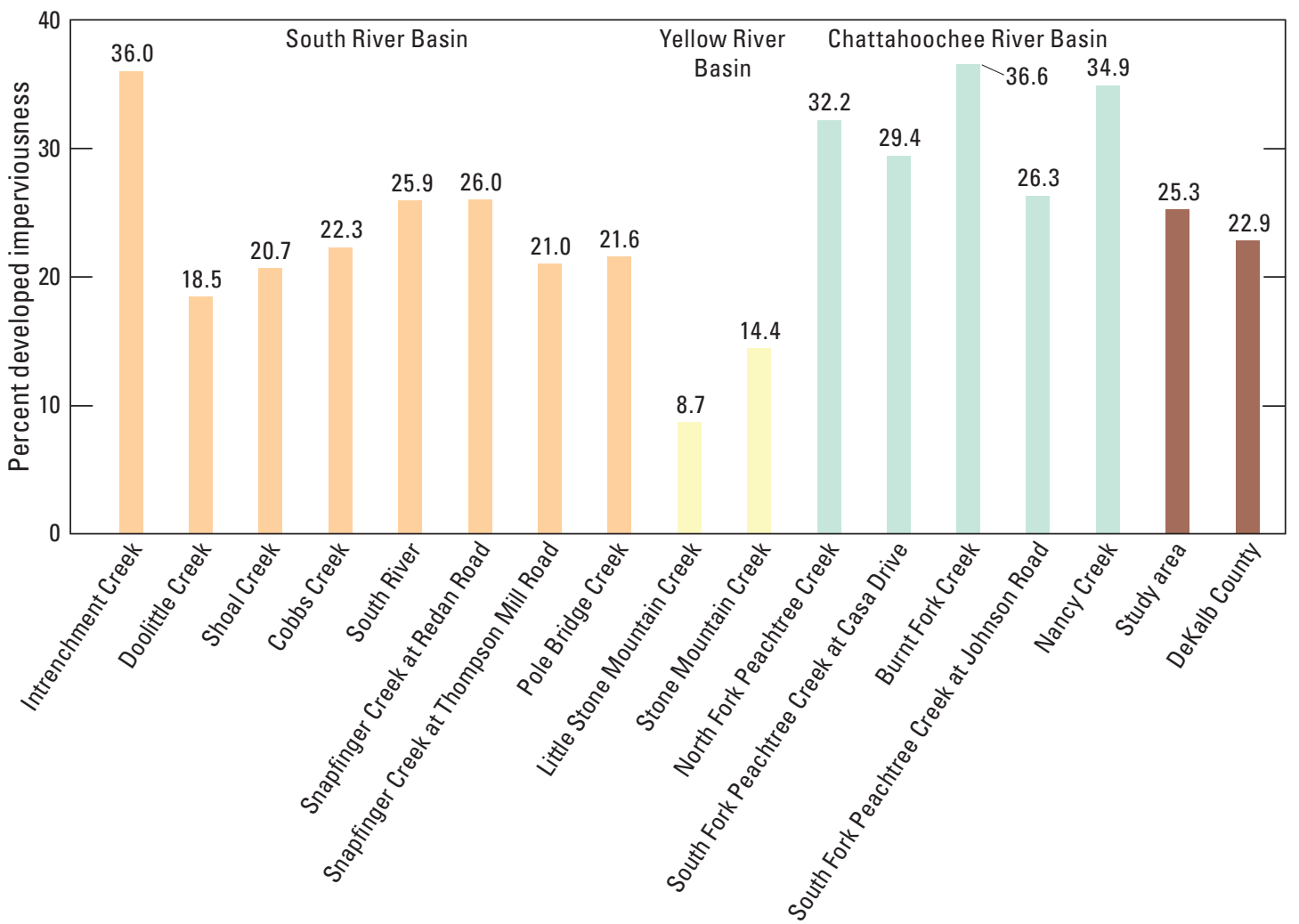

Watershed

Figure 7. Percent developed imperviousness within the 15 monitored watersheds in DeKalb County, Georgia, 2015. Derived from the National Land Cover Database (NLCD) 2011 dataset (U.S. Geological Survey, 2011). 


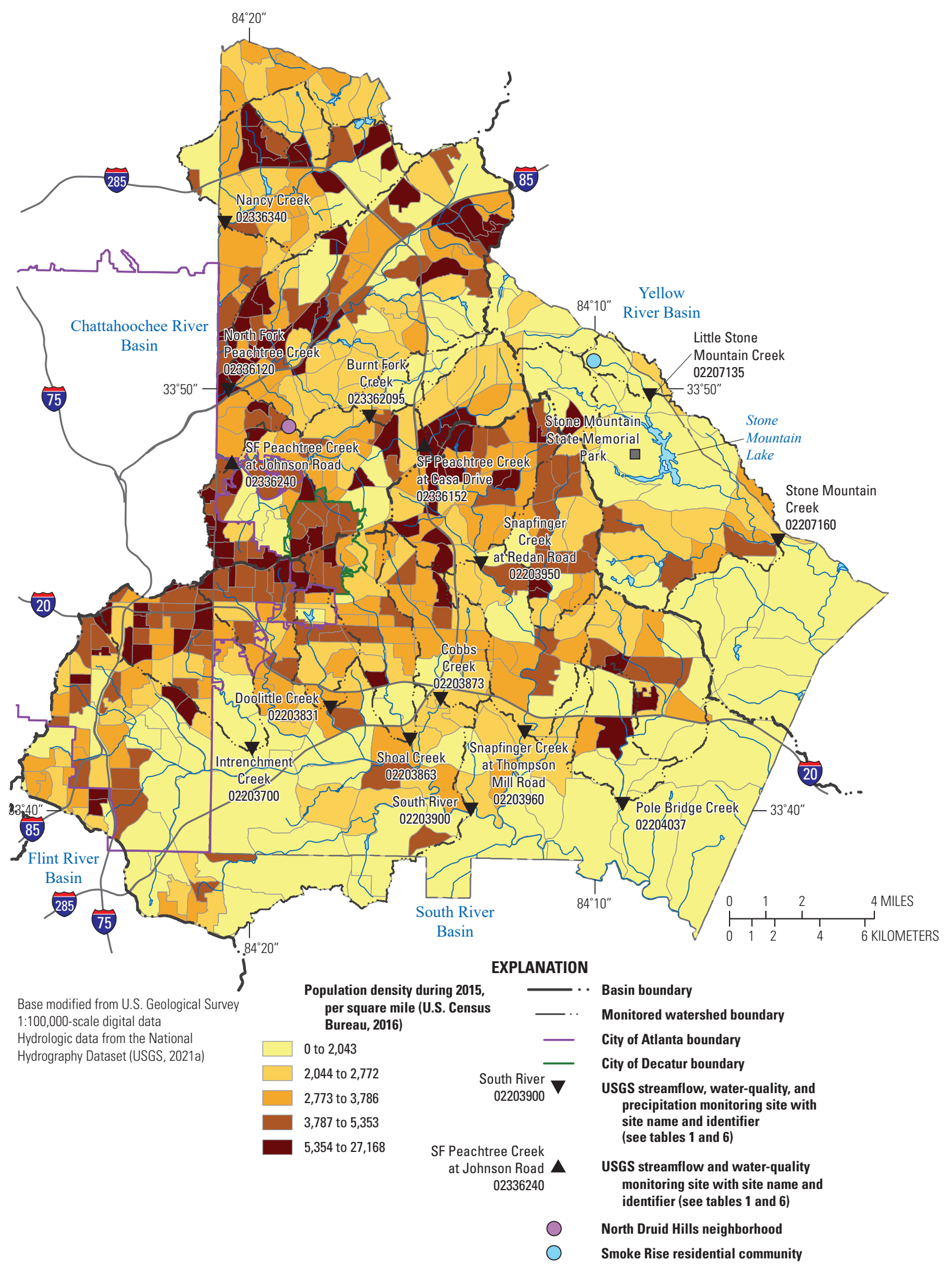

Figure 8. Population density for the area of the 15 monitored watersheds and DeKalb County, Georgia, 2015. Data from American community survey 5-year estimates of 2011-2015 block group data, U.S. Census Bureau (2016). Abbreviation: SF, South Fork. 


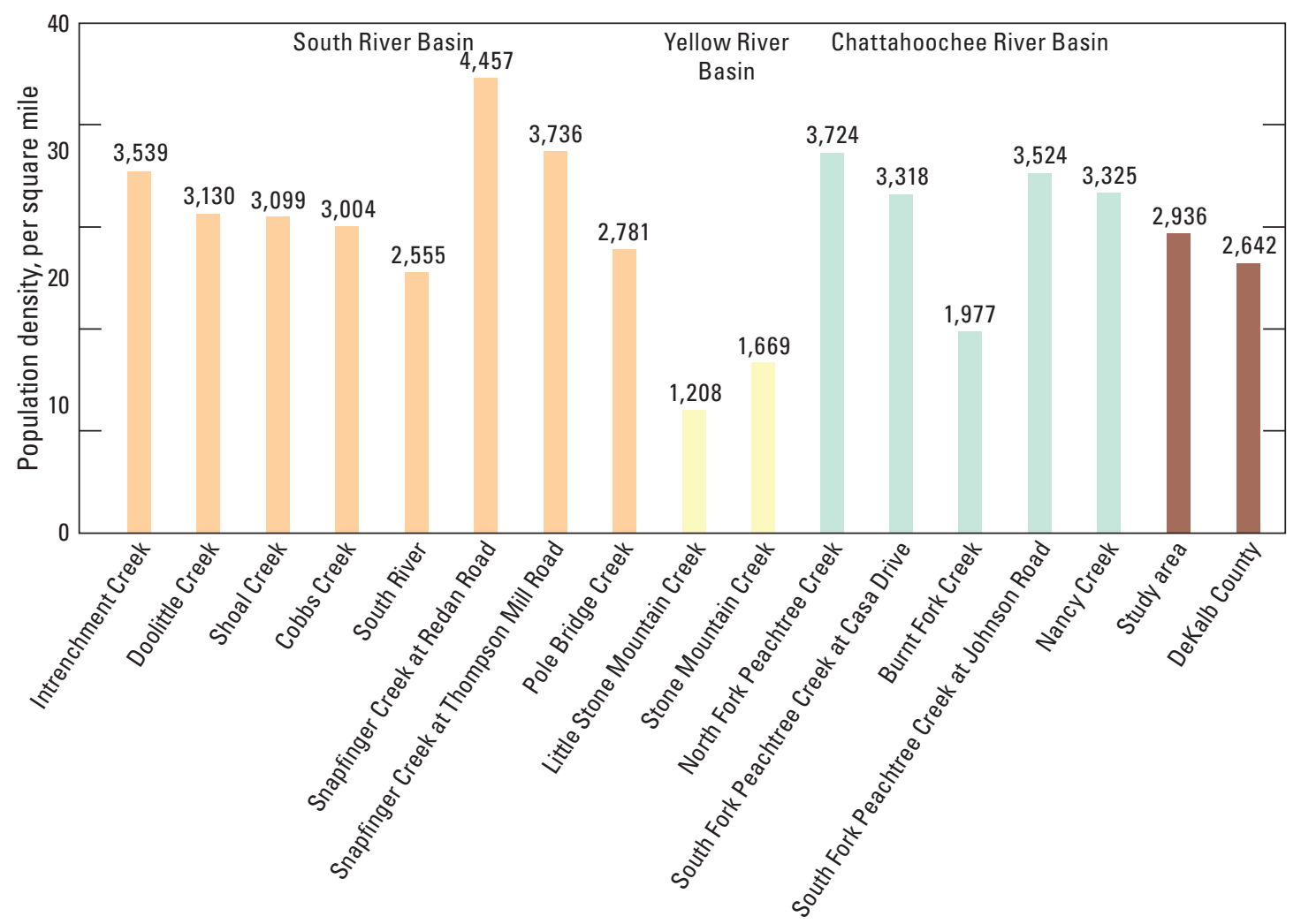

Watershed

Figure 9. Population density of the 15 monitored watersheds in DeKalb County, Georgia, 2015. Data from the American community survey 5-year estimates of 2011-2015 block group data, U.S. Census Bureau (2016).

\section{Water Budget}

The effects of climate, watershed characteristics, and land use on the hydrologic cycle of the 15 study watersheds were assessed by evaluating several components of the water budget and comparing these to watershed attributes. Water budget components include precipitation, stream runoff, evapotranspiration, and groundwater inflows, outflows, and changes in storage. Precipitation and runoff were measured for each study watershed. These data were used to compute annual and monthly average precipitation and runoff; to calculate runoff ratios, base-flow runoff, and the BFI; and to estimate long-term evapotranspiration. Variations in runoff between the watersheds can be the result of differences in precipitation, watershed characteristics, and land use. Droughts and wet climate conditions also affect the hydrologic cycle, including runoff, runoff ratios, and watershed storage in soil water and groundwater.

\section{Climate}

DeKalb County has a humid, subtropical climate characterized by warm, humid summers and cool, wet winters. Monthly average air temperatures ranged from 42.2 degrees
Fahrenheit $\left({ }^{\circ} \mathrm{F}\right)$ in January to $79.8^{\circ} \mathrm{F}$ in July (based on the 30-year average during 1981-2010 for Atlanta DeKalb Peachtree Airport station USW00053863, National Oceanic and Atmospheric Administration, 2018). Average annual precipitation at this station for the same period was 52.97 inches per year (in/yr), with higher precipitation in the winter (4.93 inches per month [in/mo], January to March) and summer (4.63 in/mo, July to September) and lower precipitation in the spring (4.15 in/mo, April to June) and fall (3.94 in/mo, October to December). Winter rainstorms are characterized by long duration, evenly distributed, and typically low-intensity frontal systems. In contrast, spring and summer rainstorms are characterized by short duration, unevenly distributed, intense convective thunderstorms.

Evapotranspiration is a substantial portion of the water budget, with mean annual evapotranspiration estimated to account for 50 to 59 percent of the annual precipitation in the study area, based on climate and land-cover data (Sanford and Selnick, 2013). Evapotranspiration varies substantially by season and is highest in the summer as the result of air temperature and solar radiation that provide the energy for evapotranspiration being at peak values. The seasonality in evapotranspiration results in a strong seasonal pattern in runoff (for example, Aulenbach and others, 2017a). A small watershed study adjacent to DeKalb County indicated that water-limited 
conditions, where potential evapotranspiration exceeded precipitation, frequently occurred during the summer months (Aulenbach and Peters, 2018). These water-limiting conditions resulted in climatic water deficits (Stephenson, 1990, 1998) in late summer, as evident from estimated evapotranspiration being well below potential evapotranspiration, indicating reduced plant transpiration due to lack of available water for uptake. Seasonal water-limiting conditions and water deficits are expected to similarly affect the study watersheds herein.

Weekly estimates of drought severity in DeKalb County during the study period, as classified by the U.S. Drought Monitor (2020), are presented in figure 10. The U.S. Drought Monitor classifies drought based on a combination of meteorological, hydrological, and agricultural drought characteristics. In the year preceding the study period, 2011, drought conditions typically ranged from abnormally dry to extreme drought. In 2012, moderate to extreme drought occurred. Droughts abated during 2013-2015, with only short periods of abnormally dry conditions. The latter half of 2016 had a rapid onset of severe to extreme "flash" drought.

\section{Precipitation}

Precipitation, as determined from the USGS precipitation monitoring sites (fig. 1; table 6), averaged $50.7 \mathrm{in} / \mathrm{yr}$ for the study watersheds (fig. 11) and $52.9 \mathrm{in} / \mathrm{yr}$ for DeKalb County for 2012-16; these averages are near the long-term average of $53.0 \mathrm{in} / \mathrm{yr}$ reported at the Atlanta Dekalb Peachtree Airport weather station (National Oceanic and Atmospheric Administration, 2018). During 2012-16, annual precipitation in the study area was variable, ranging from 36.8 inches (2012) to 64.7 inches (2015). Two years were dry, with precipitation less than 41 inches (2012 and 2016); 2 years were wet, with precipitation more than 63 inches (2013 and 2015); and 1 year was near average (2014). The two dry years corresponded with droughts (fig. 10).
The spatial variability of precipitation over the study area for the 2012 to 2016 study period was small, with a range of 2.9 inches between watersheds (fig. 11). Spatial variability between watersheds was much larger for individual years, with the maximum differences ranging from 4.9 inches (2012) to 11.0 inches (2015). The relative differences in precipitation between watersheds were inconsistent from year to year. Overall, the watersheds in the south-central part of the county (Doolittle Creek, Shoal Creek, Cobbs Creek, and Snapfinger Creek at Thompson Mill Road) appear to have had somewhat higher precipitation during the study period. Variability in spatial patterns in precipitation can be caused by factors such as topography (McCrary, 2011), the variable distribution of precipitation from convective thunderstorms, and proximity and orientation to urban heat islands (Bornstein and Lin, 2000; Dixon and Mote, 2003; Mote and others, 2007; Shem and Shepherd, 2009). Long-term precipitation variability between watersheds may have been small as the result of the similar ranges in watershed elevations (table 7) and the similar position of the study watersheds downwind of Atlanta (predominant wind direction is from the west and northwest). Variations in precipitation are important to consider when comparing the resulting stream runoff among watersheds.

Average monthly precipitation for the period 2014 to 2016 ranged from similar lows of 2.58 inches (March) and 2.59 inches (October) to a high of 6.49 inches (December; fig. 12). Average monthly precipitation is only presented for years 2014 to 2016 to facilitate a comparison with runoff data that were only available at all 15 watersheds for this period. Average monthly precipitation did not exhibit a coherent seasonal pattern. Because of a high amount of interannual variability in monthly precipitation, these particular years do not match the pattern in long-term monthly average precipitation measured at the Atlanta Dekalb Peachtree Airport.

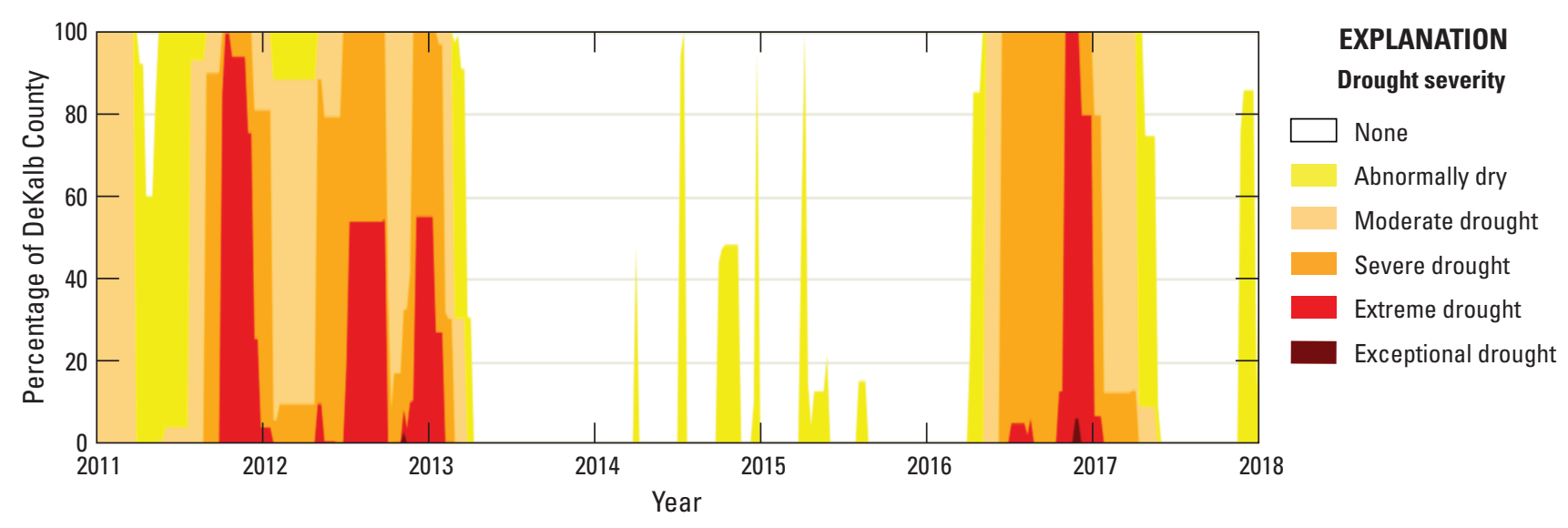

Figure 10. Weekly drought severity in DeKalb County, Georgia, for years 2011-17 as a percentage of county area. Modified from U.S. Drought Monitor (2020). 


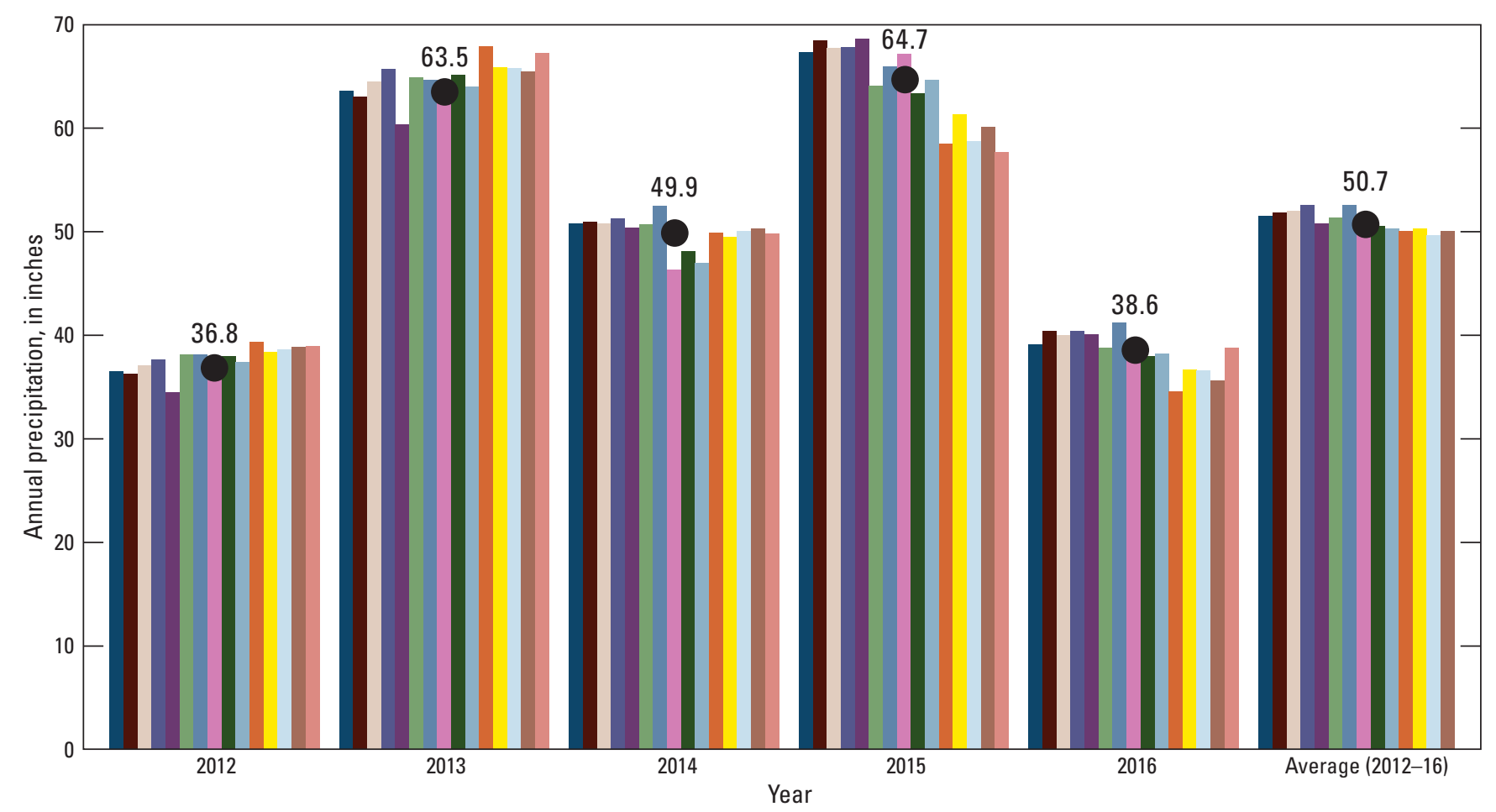

EXPLANATION

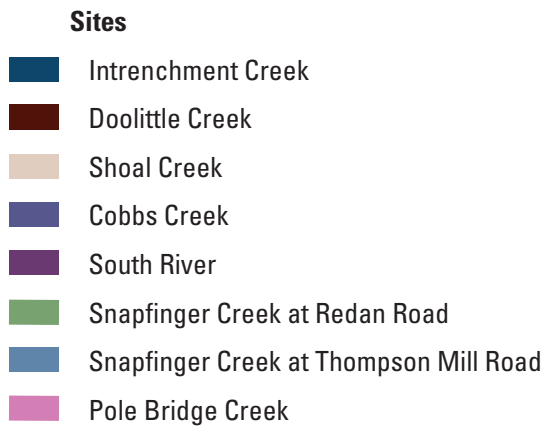

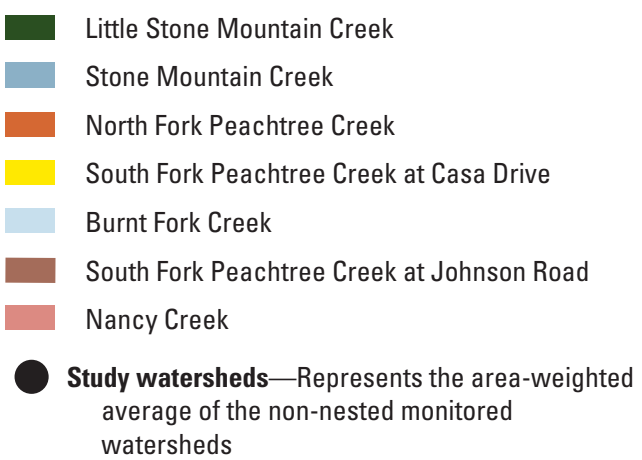

Figure 11. Annual precipitation totals for 15 monitored watersheds in DeKalb County, Georgia, 2012-16.

\section{Runoff and Water Budgets}

Runoff is largely controlled by various components of the water budget - the amount of precipitation and evapotranspiration and changes in watershed storage (soil water and groundwater). Runoff is also affected by basin characteristics such as land use, impervious area, vegetation, soil types, drainage area, basin shape, drainage network patterns, topography (land-surface slopes), and the presence of lakes and reservoirs. Watershed water budgets are complicated by water management infrastructure and activities that supply, remove, and redistribute water into, out of, within, and between watersheds. Quantifying the effects of water management on runoff is beyond the scope of this study, but it is important to be aware of their possible influences, which are summarized in the "Water Infrastructure in DeKalb County" sidebar.
Annual runoff for the study watersheds area averaged $22.0 \mathrm{in} / \mathrm{yr}$ from 2014 to 2016 (fig. 13). Runoff was measured for all 15 watersheds during these years, so this period was used for making comparisons. These 3 years represent an average (2014), wet (2015), and dry (2016) year for precipitation (fig. 11) and therefore compose a set of climatic conditions that may be reasonably representative of the average and of the variability observed in the long-term record. During these years, average annual runoff ranged from 17.0 inches (2016) to 25.2 inches (2015) in the study watersheds (fig. 13). Variations in annual runoff were largely related to total annual precipitation; however, runoff totals in 2014 (17.9 inches) and 2016 (17.0 inches) were similar despite 2014 having 11.3 inches more precipitation than 2016. Both 2014 and 2016 followed years with similarly above average precipitation. Average base flows in the Decembers prior to the start of 


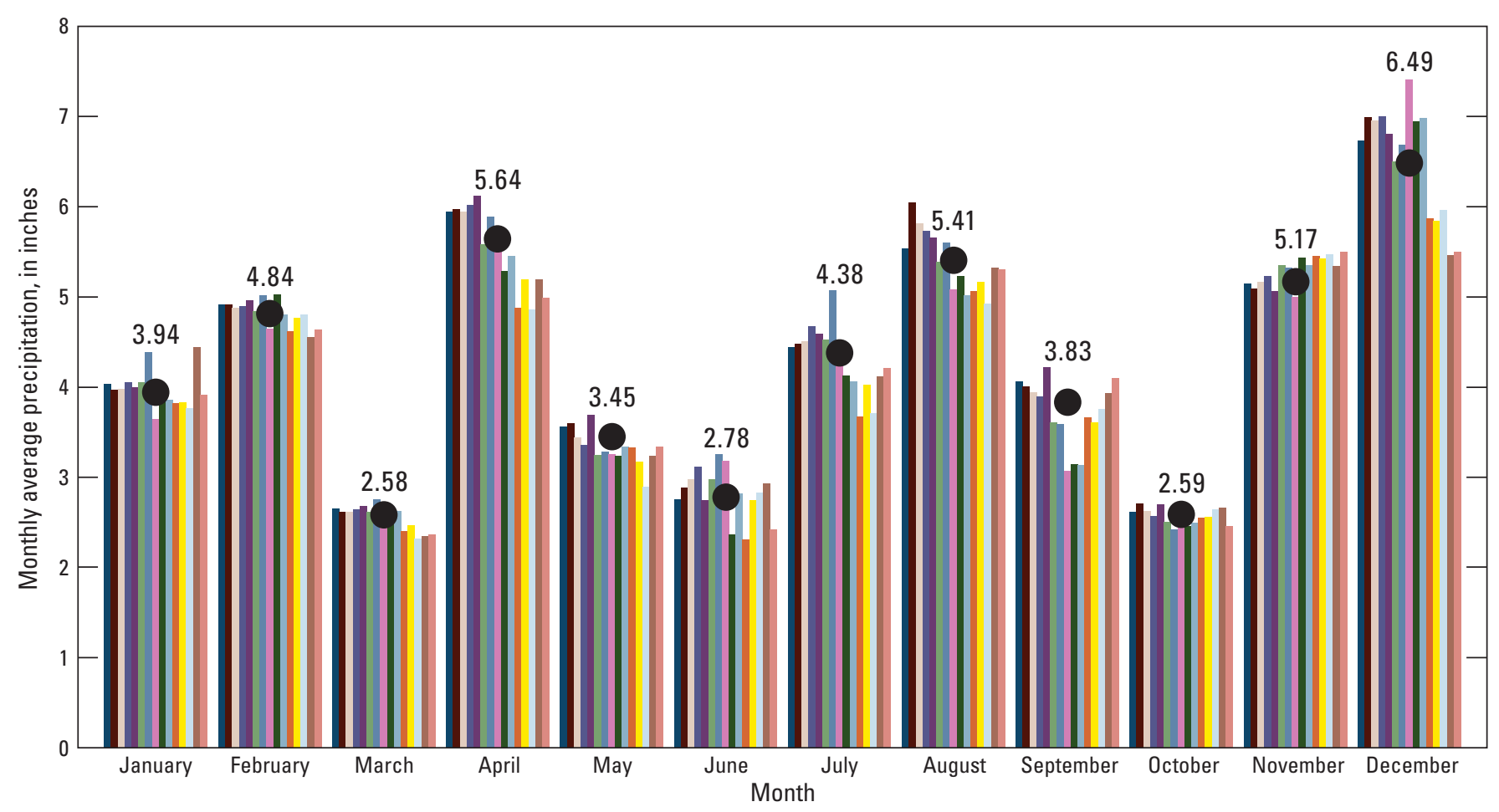

EXPLANATION
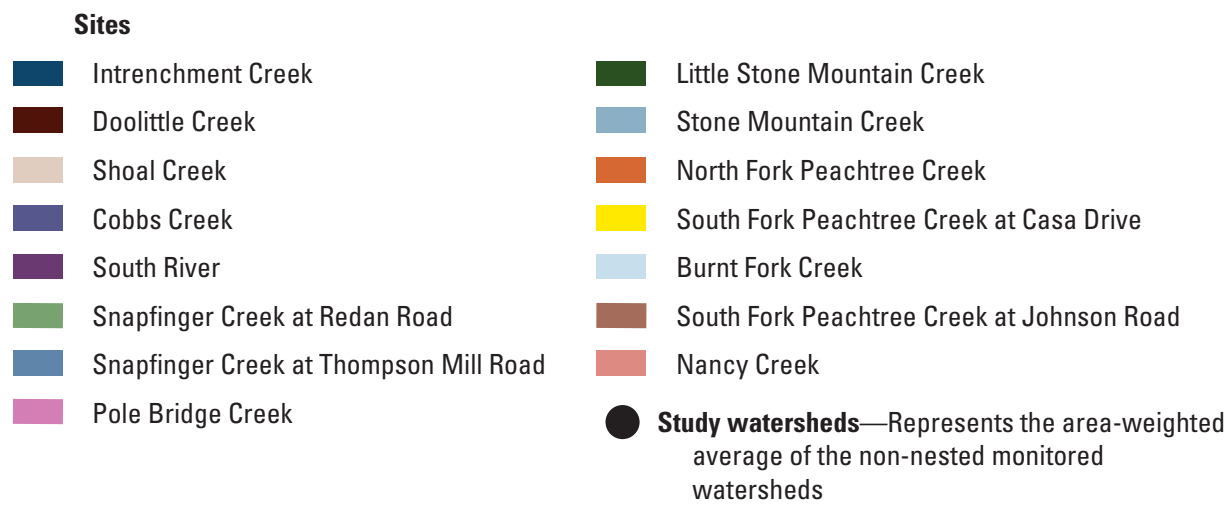

Figure 12. Monthly average precipitation for 15 monitored watersheds in DeKalb County, Georgia, 2014-16.

those years, however, indicate that base flows were 88 percent higher at the start of 2016 than at the beginning of 2014, suggesting that higher base-flow runoff generated from watershed storage likely compensated for the lower precipitation in 2016. Furthermore, much of the additional precipitation in 2014, relative to 2016, occurred during the growing season (April through September; 6.8 of the 11.3 additional inches), which likely contributed mostly to increased evapotranspiration as opposed to additional runoff because of water-limiting conditions that occur during the growing season.

The variability in runoff between watersheds was substantial (fig. 13), and the differences do not appear to be directly related to variations in watershed precipitation (fig. 11). Average annual runoff was highest at the Intrenchment Creek and Snapfinger Creek at Thompson Mill
Road watersheds and lowest at the Doolittle Creek, Little Stone Mountain Creek, and Stone Mountain Creek watersheds during 2014 to 2016. The watersheds with the highest annual runoffs varied by year, while the group of watersheds with the lowest annual runoffs were more consistently similar among years. The three watersheds with the lowest runoff have the three lowest percentages of imperviousness among the study watersheds (fig. 7), and runoff for the Stone Mountain Creek watershed was likely affected by its large reservoir.

Monthly average runoff had a strong seasonal pattern (fig. 14). Runoff was highest in December (3.13 inches), coincident with the highest average monthly precipitation (6.49 inches, fig. 12), seasonally wet hydrological conditions (high groundwater levels and base flow and wet soil moisture conditions), and low evapotranspiration. Runoff was lowest in 


\section{Water Infrastructure in DeKalb County}

Water supply, stormwater, and wastewater services in the study watersheds are provided by DeKalb County and the City of Atlanta. The water supply (withdrawal) for both jurisdictions comes from intakes on the Chattahoochee River outside of the study area. The major discharges (returns) of water in the county occur outside of the monitored watershed areas, with exceptions in the Intrenchment Creek watershed during wet weather conditions which are described later. The two advanced wastewater treatment plants (Pole Bridge and Snapfinger) in DeKalb County have outfalls downstream of the monitored watersheds in the South River Basin. Water from the City of Atlanta Intrenchment Creek Water Reclamation Center (WRC; located within the Intrenchment Creek watershed) flows to the South River WRC for further treatment, whereas the South River WRC (located within the South River watershed) has its outfall on the Chattahoochee River. Having intakes and returns that are outside of the watershed areas minimizes human effects on the study watershed water budgets because much of the water used for human consumption is returned to these treatment plants by the way of the sanitary sewer system. Not all water is returned, however, and septic systems, irrigation, and leakage of water supply and sewer lines into surface and groundwaters contribute to inputs to the watersheds. The fate of inputs from sources such as septic systems and irrigation is complicated because these inputs can contribute to increased evapotranspiration and groundwater recharge, depending on hydrologic and climatic conditions. Losses of water within a watershed can occur when stormwater and groundwater inflow and (or) infiltrate into storm, sanitary, and combined sewers that discharge outside of the watershed's drainage area. The watershed and storm sewersheds may not align, such that some stormwater runoff is transferred between watersheds or circumvents the streamgage. BMPs for stormwater management include using retention ponds to capture stormwater runoff or detention ponds to delay stormwater runoff, which can affect the quantity, quality, and timing of that runoff.

The water budget of the Intrenchment Creek watershed, which is a subbasin of the South River watershed, is further complicated by the implementation of combined sewers for sanitation and storm runoff in the upper part of the watershed known as the Custer Avenue basin (located within the City of Atlanta). The operation of the combined sewers has variable effects on the water budget, the magnitude and timing of runoff, and water quality. During dry weather conditions when the CSO contains little runoff, the water is treated by the Intrenchment Creek and South River WRCs and discharged to the Chattahoochee River. During wet weather conditions, CSO is collected, initially treated, and stored at the Custer Avenue Water Quality Control Facility (WQCF), Custer Avenue storage facility, and Intrenchment Creek Storage Tunnel before undergoing further treatment at the Intrenchment Creek WQCF. Treated water is then discharged to Intrenchment Creek within the monitored watershed. This discharge typically occurs during what would be the latter part of stormflow recession and the return to base-flow conditions and results in notable elevated flows on Intrenchment Creek. If the capacities of the storage facility and tunnel are exceeded, treated CSO overflow is discharged into Intrenchment Creek at the Custer Avenue WQCF, which is also within the monitored watershed.
October ( 0.83 inch), coincident with the second lowest average monthly precipitation (2.59 inches) and characteristically dry hydrologic conditions (low groundwater levels and base flow and dry soil moisture conditions). The decline in runoff during the growing season (April through September) was the result of high evapotranspiration that typically exceeds precipitation. The accumulated effects of these water-limiting conditions result in minimal groundwater recharge, declining groundwater storage, and a progressive decline in baseflow-sustaining groundwater discharges. Runoff increased during the dormant season (October through March) because of increases in base flow resulting from higher groundwater recharge when evapotranspiration is seasonally low, and higher stormflow generation, which occurs during wetter hydrological conditions. The effects of higher precipitation in February, April, August, and December (fig. 12) are apparent in monthly runoff within the overall seasonal pattern.
The runoff ratio is the proportion of precipitation that occurs as stream runoff (fig. 15). The average runoff ratio was 40.9 percent for the period 2014 to 2016 for the study watersheds. This indicates evapotranspiration represented about 59.1 percent of precipitation, assuming that changes in storage over this period were negligible. The runoff ratio was lowest in 2014 (35.9 percent), a year with average precipitation, and highest in 2016 (44.0 percent), a year with below average precipitation. In general, more runoff and higher runoff ratios were expected when hydrological conditions were wet because the storm runoff response was larger and less precipitation was used to replenish watershed storage. However, 2016 had the highest runoff ratio despite being the driest of the 3 years. This was the result of base-flow runoff from watershed storage that accrued during the prior wet year and illustrates the substantial effects of storage on runoff and the overall water budget.

Differences in annual runoff ratios between watersheds largely reflected the differences observed for annual runoff (fig. 13) because precipitation was relatively similar across 


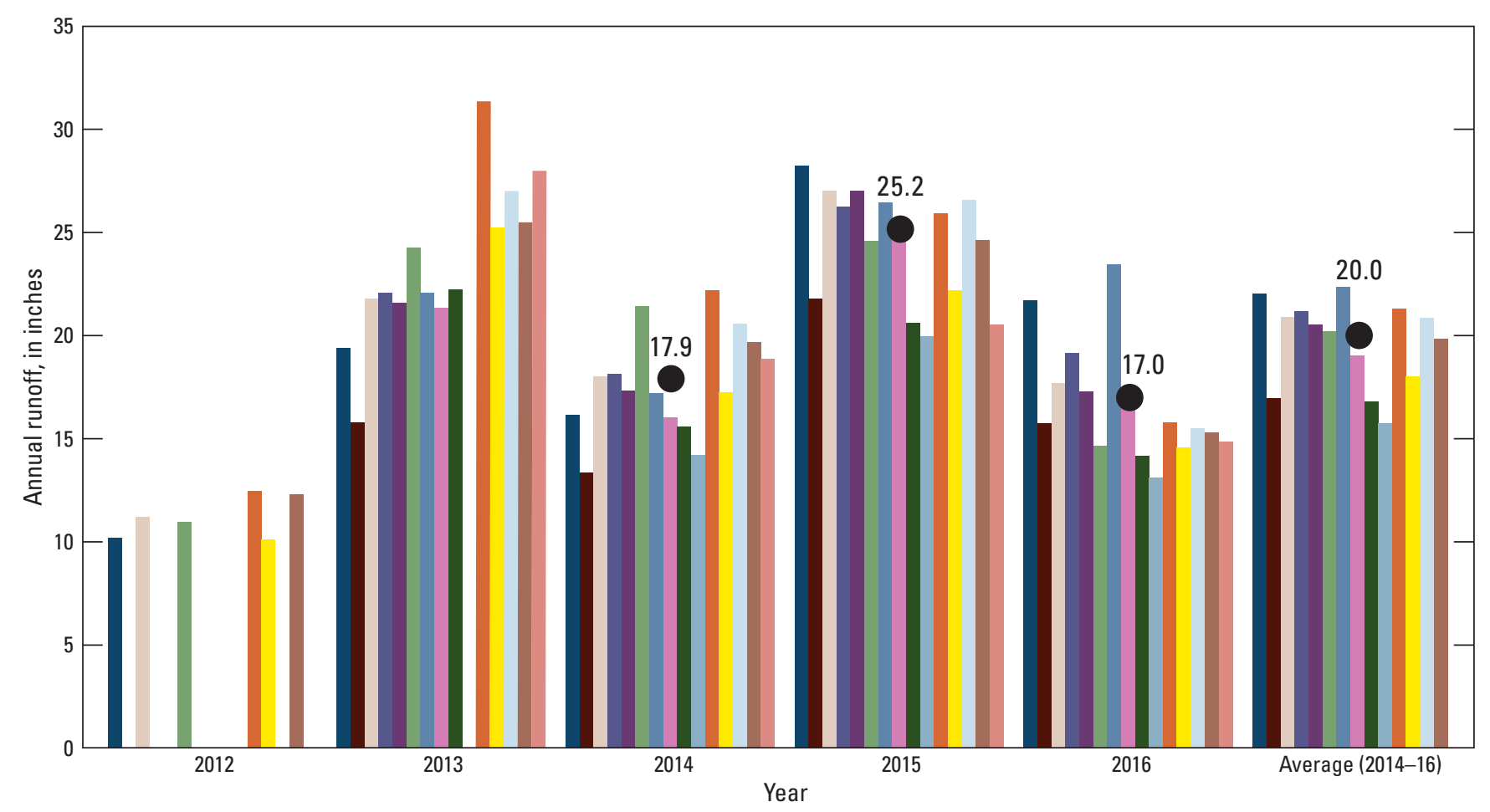

EXPLANATION

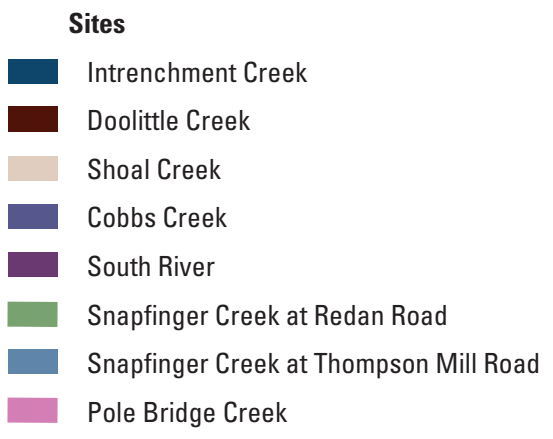

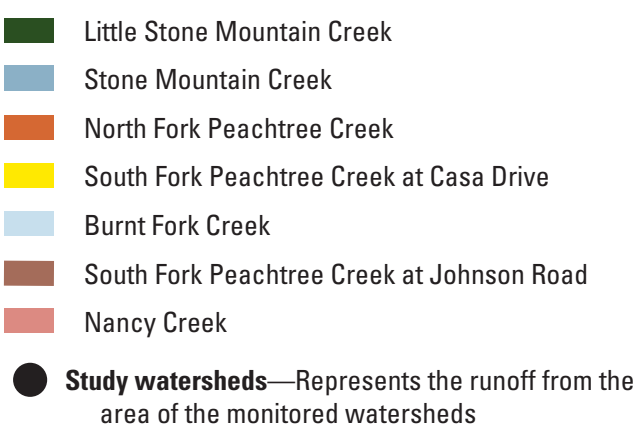

Figure 13. Annual runoff for 15 monitored watersheds in DeKalb County, Georgia, 2012-16, and the annual average runoff for 2014-16.

these watersheds (fig. 11). Runoff ratios were highest at the Snapfinger Creek at Thompson Mill Road, North Fork Peachtree Creek, and Burnt Fork Creek watersheds for 2014 to 2016. The North Fork Peachtree Creek and Burnt Fork Creek watersheds had imperviousness greater than 30 percent (fig. 7). Runoff ratios were lowest for the three watersheds that had the lowest runoff (Doolittle Creek, Little Stone Mountain Creek, and Stone Mountain Creek; figs. 13 and 15).

The monthly average runoff ratio had a strong seasonal pattern with a substantially larger proportion of precipitation, resulting in runoff during the dormant season (fig. 16). The runoff ratio was highest in January (64.0 percent) and lowest in July (23.0 percent) for the period 2014 to 2016 for the study watersheds. The seasonal pattern was fairly smooth despite reflecting only 3 years of data with varying climate conditions.
Monthly precipitation variations (fig. 12) were not as apparent as they were for runoff (fig. 14), indicating that seasonal patterns in runoff ratios resulted predominantly from seasonality in runoff. March was the only stand-out from the seasonal pattern. March had the lowest monthly average precipitation (2.58 inches), and, while runoff was low (fig. 14), base flow from prior groundwater storage still provided a substantial amount of runoff that resulted in a higher runoff ratio than would normally be expected from the overall seasonal pattern.

The seasonal pattern in the runoff ratio predominantly reflected the effects of seasonal variations in evapotranspiration on the water cycle and particularly on watershed storage conditions. Watershed storage was typically depleted during the growing season because of high evapotranspiration that results in water-limiting conditions (precipitation $<$ potential 


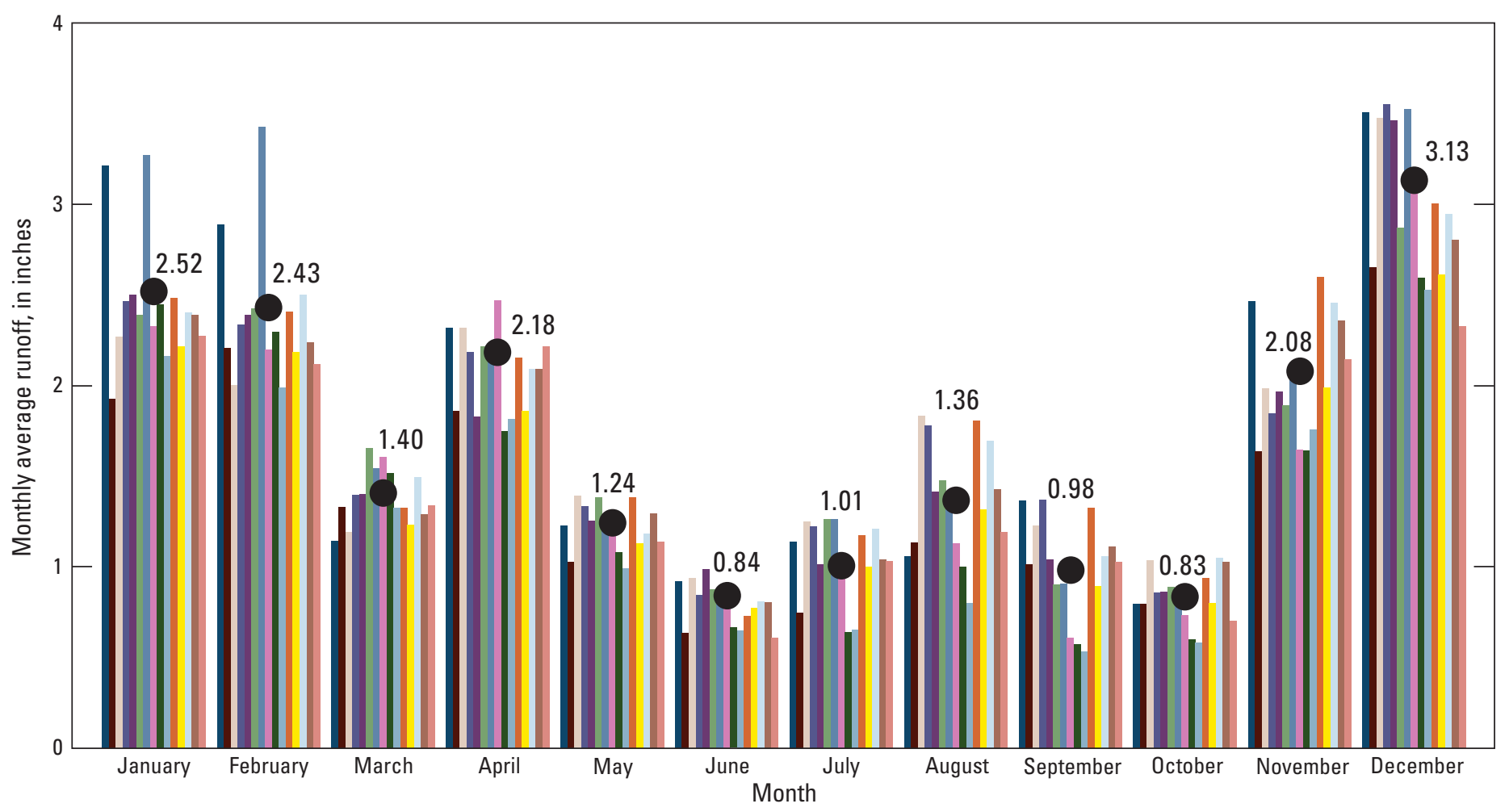

Sites
Intrenchment Creek
Doolittle Creek
Shoal Creek
Cobbs Creek
South River
Snapfinger Creek at Redan Road
Snapfinger Creek at Thompson Mill Road
Pole Bridge Creek

EXPLANATION

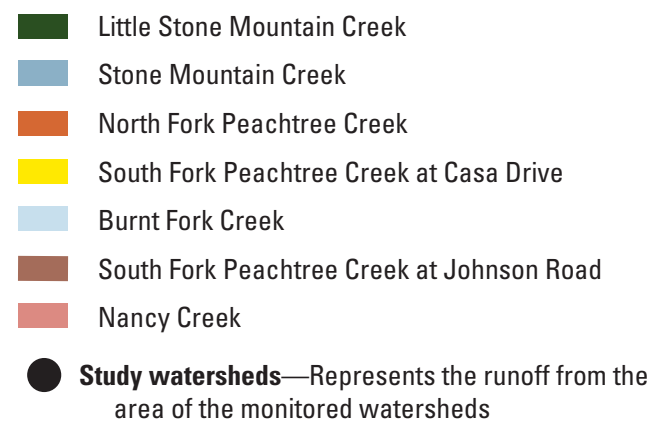

Figure 14. Monthly average runoff for 15 monitored watersheds in DeKalb County, Georgia, 2014-16.

evapotranspiration) and water deficits (actual evapotranspiration $<$ potential evapotranspiration) and was replenished during the first part of the dormant season while evapotranspiration is low. Runoff ratios were typically highest toward the end of the dormant season because (1) evapotranspiration was relatively low, (2) a larger portion of precipitation went to runoff than to recharge watershed storage, and (3) base-flow runoff was high. Runoff ratios typically were lowest toward the end of the growing season because (1) evapotranspiration was still fairly high, (2) a large portion of precipitation went to recharge watershed storage instead of stormflow runoff, and (3) base-flow runoff was low.

Annual stormflow runoff (fig. 17) varied similarly to annual precipitation (fig. 11). Stormflow runoff varied greatly between watersheds. Stormflow runoff amounts were highest from the Intrenchment Creek and North Fork Peachtree Creek watersheds, which had high percentages of impervious areas, and were lowest from the Little Stone Mountain Creek and Stone Mountain Creek watersheds, which had the two lowest percentages of impervious areas (fig. 7; table 10).

The BFI for the study watersheds averaged 0.43 for the period 2014 to 2016 (fig. 18), indicating that 43 percent of runoff occurred as base flow, and the remainder occurred as stormflow. The low proportion of base-flow runoff in most of the watersheds is indicative of urban streams affected by impervious areas. The BFI was highest at the Little Stone Mountain Creek watershed (0.59) and was also high at the Doolittle Creek (0.52) and Stone Mountain Creek (0.54) watersheds. Little Stone Mountain Creek and Doolittle Creek are small watersheds, and Little Stone Mountain Creek had the 


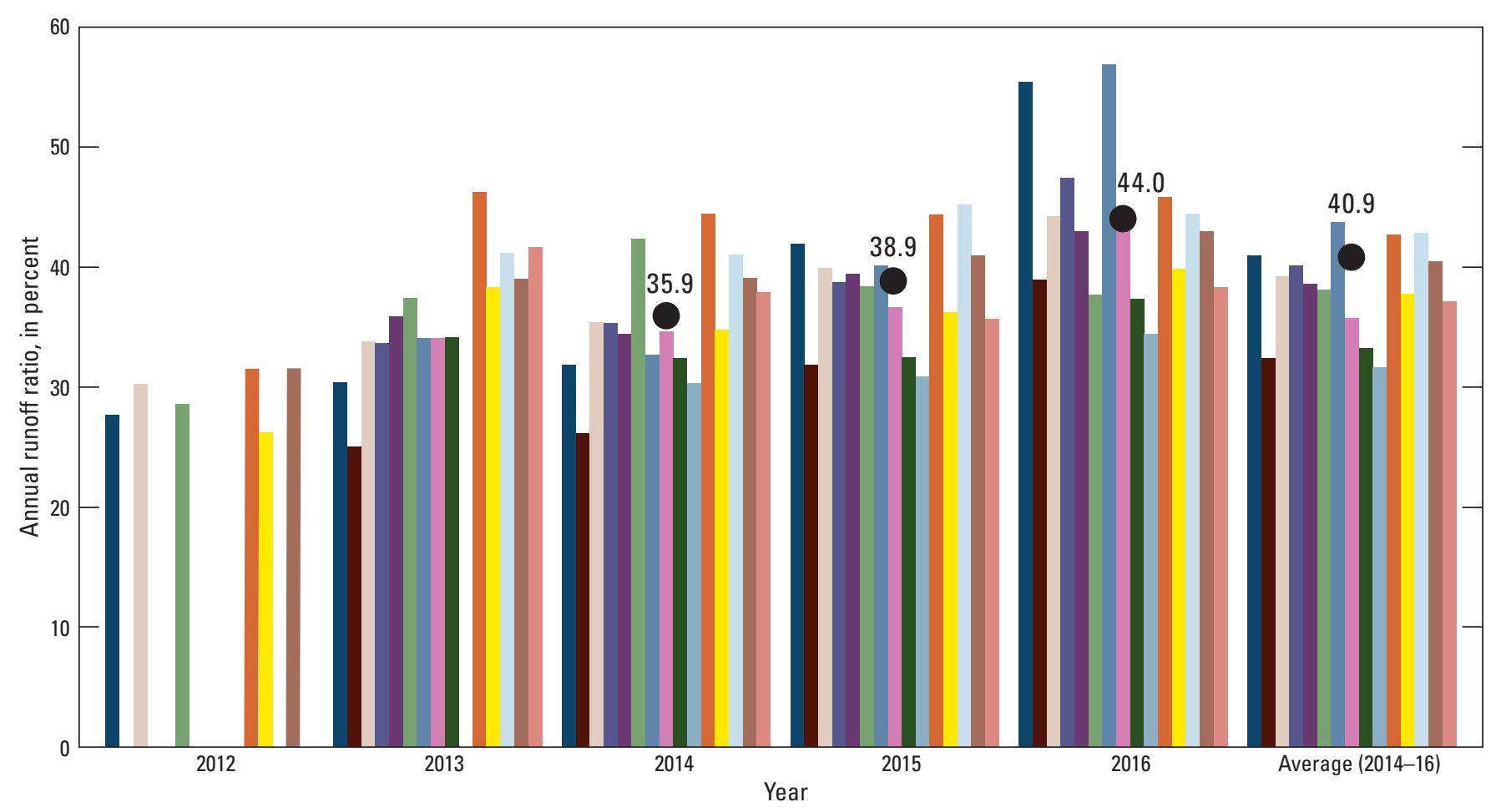

EXPLANATION

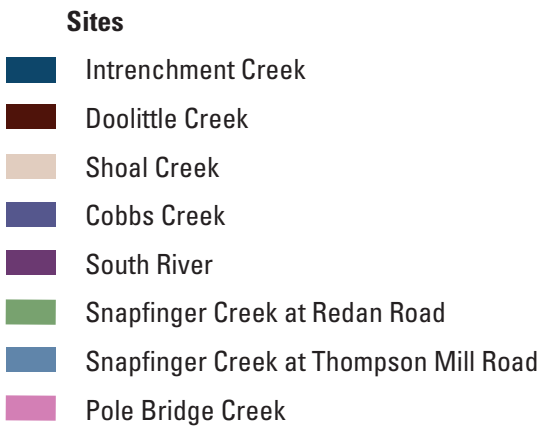

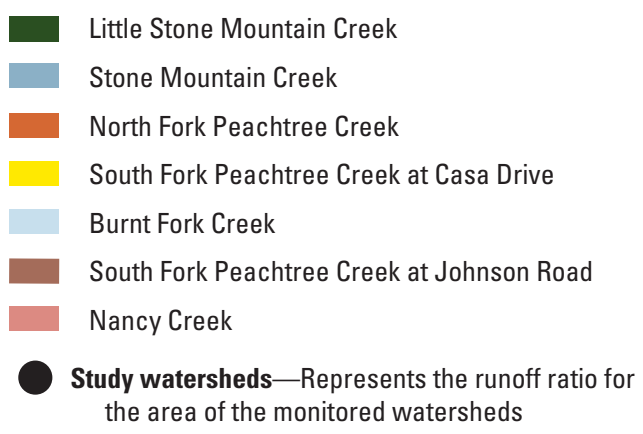

Figure 15. Annual runoff ratio for 15 monitored watersheds in DeKalb County, Georgia, 2012-16.

lowest percentage of impervious area of the study watersheds (table 10). The Stone Mountain Creek base-flow separation may not fully reflect base flow because of the effects of the reservoir and dam within this watershed. The lowest BFI was at the North Fork Peachtree Creek watershed (0.32). Several other watersheds had low and similar BFIs, ranging from 0.38 to 0.40 at Intrenchment Creek, South Fork Peachtree Creek at Casa Drive and Johnson Road, Burnt Fork Creek, and Nancy Creek. These six watersheds with the lowest BFIs had the six highest percentages of impervious areas (fig. 7).

BFIs varied annually and were similar in 2014 and 2015 (both 0.41 ) and highest in $2016(0.49)$. The higher BFI in 2016 was the result of below average precipitation resulting in lower stormflow runoff combined with particularly high base flows at the beginning of 2016 from groundwater storage and is consistent with the high runoff ratio for 2016 (fig. 15).

Monthly average base-flow runoff exhibited a strong seasonal pattern (fig. 19), reflecting the effect of the seasonality in evapotranspiration on groundwater recharge and storage. Base flow was about twice as high during January through April than it was during June through October. Monthly average stormflow runoff largely reflected variations in monthly average precipitation (fig. 12). Variations in the monthly BFI were inversely related to variations in the monthly average stormflow runoff. 


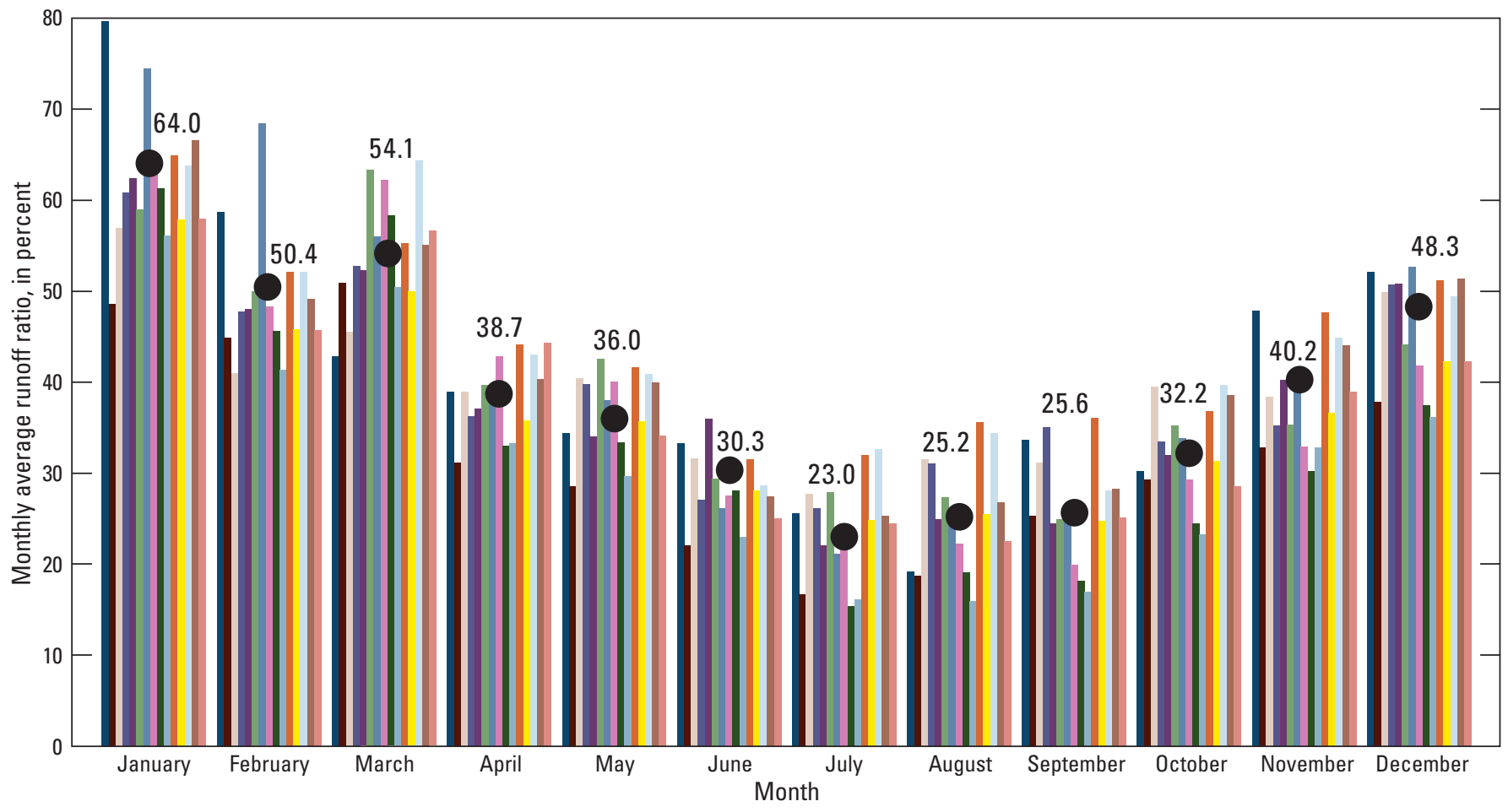

EXPLANATION
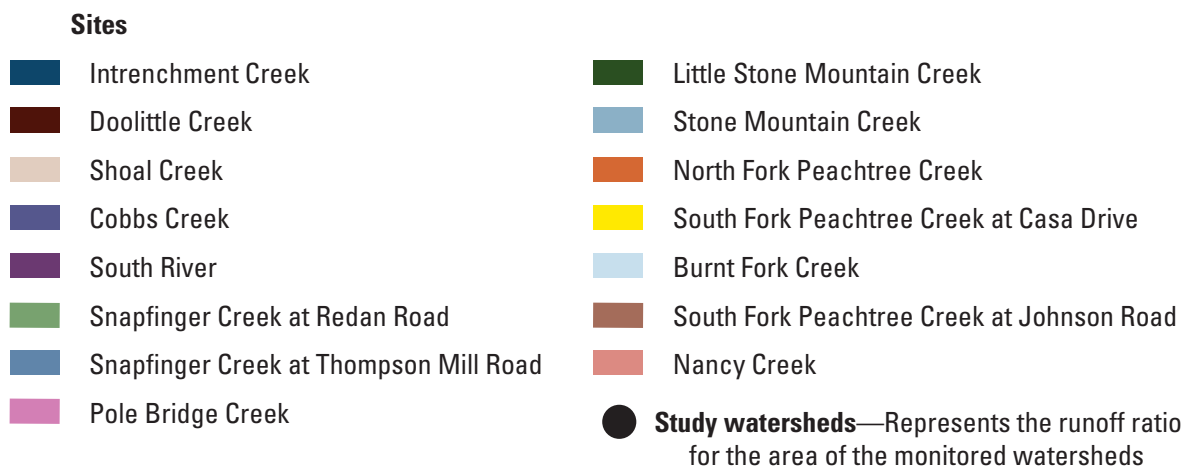

Figure 16. Monthly average runoff ratio for 15 monitored watersheds in DeKalb County, Georgia, 2014-16.

\section{Relations Between Runoff Metrics and Watershed Characteristics}

To understand the possible effects of watershed characteristics on runoff along with relations between various runoff metrics, correlations between these variables were evaluated (table 11). Runoff metrics evaluated were precipitation, runoff, the runoff ratio, base-flow runoff, stormflow runoff, and the BFI. Watershed characteristics evaluated were average land-surface slope, basin area, imperviousness (for watershed areas and within 100- and 200-ft stream buffers), and the topographic wetness index. The imperviousness variables were significantly correlated with most of the runoff metrics, whereas none of the other watershed characteristics had significant correlations with any of the runoff metrics. The significant intercorrelations between runoff metrics were expected because many of these metrics are interrelated.

BFI had a strong negative correlation with imperviousness $(r=-0.898$; fig. 20A), and base-flow runoff had a moderate negative correlation with imperviousness $(r=-0.637$; fig. 20B). These relations can likely be attributed to impervious cover, which reduces infiltration and limits watershed storage, thereby decreasing base-flow runoff. These base-flow variables varied similarly, as evident from the strong positive correlation ( $r=0.762$; fig. 20C). However, imperviousness is likely more strongly related to BFI than to base-flow runoff because BFI additionally incorporates the effects of higher stormflow runoff associated with higher percentages of imperviousness. 


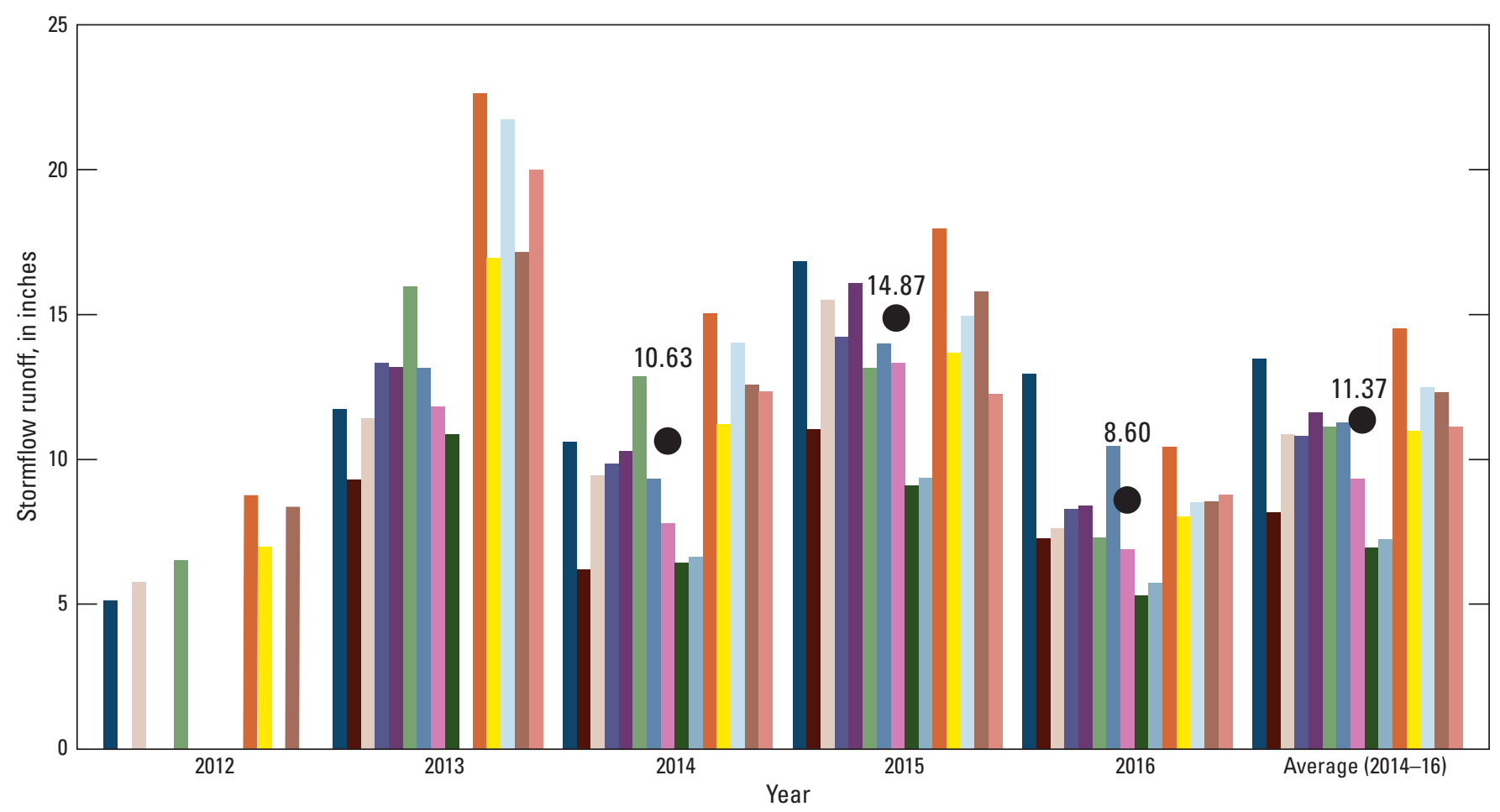

EXPLANATION

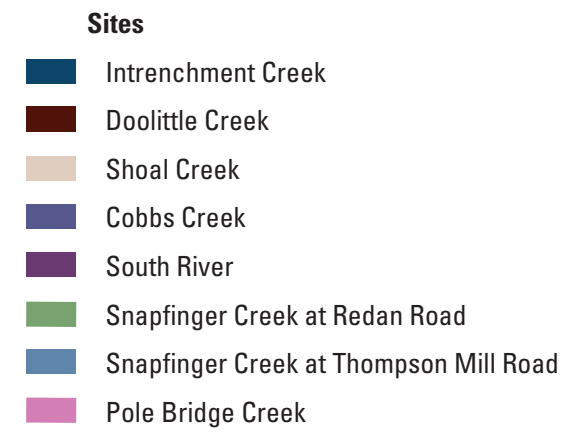

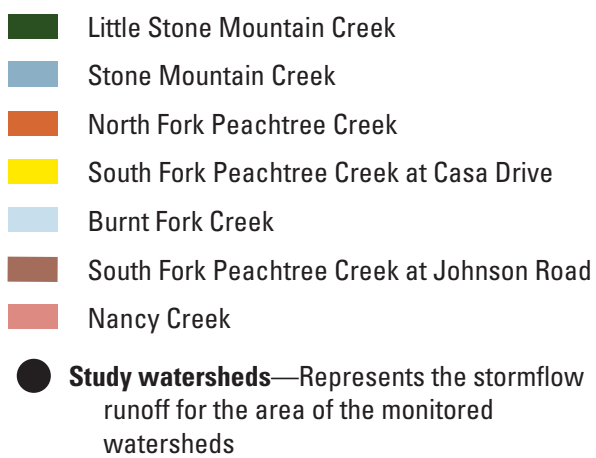

Figure 17. Annual stormflow runoff for 15 monitored watersheds in DeKalb County, Georgia, 2012-16.

There were moderate and strong positive correlations for runoff $(r=0.517$; fig. $21 A)$, the runoff ratio $(r=0.646$; fig. $21 B$ ), and stormflow runoff ( $r=0.844$; fig. $21 C$ ) with the percentage of impervious area for the study watersheds for the period 2014 to 2016. The relation for stormflow runoff indicated that stormflow runoff was about twice as high for watersheds with 35 percent imperviousness than with 10 percent imperviousness. The increases in runoff (particularly for stormflow runoff) associated with higher percentages of imperviousness are caused by increases in overland runoff on impervious surfaces and decreases in infiltration.

Moderate negative correlations existed between the runoff ratio and the BFI for the study watersheds for the period 2014 to 2016 and for 2014 and 2015 (fig. $22 A-C$ ). This pattern is likely driven by relations with imperviousness (table 11) as the runoff ratio was higher (fig. $21 B$ ) and the BFI was lower (fig. 20A) with higher imperviousness. The runoff ratio and the BFI, however, did not have a significant relation during 2016 (fig. 22D). This is consistent with an earlier finding that the runoff ratio was high during this dry year because of the contribution of base-flow runoff from watershed storage (fig. 18) while also resulting in a larger portion of runoff from base flow that resulted in a higher BFI as indicated from the spatial relation in figure $20 \mathrm{C}$. 


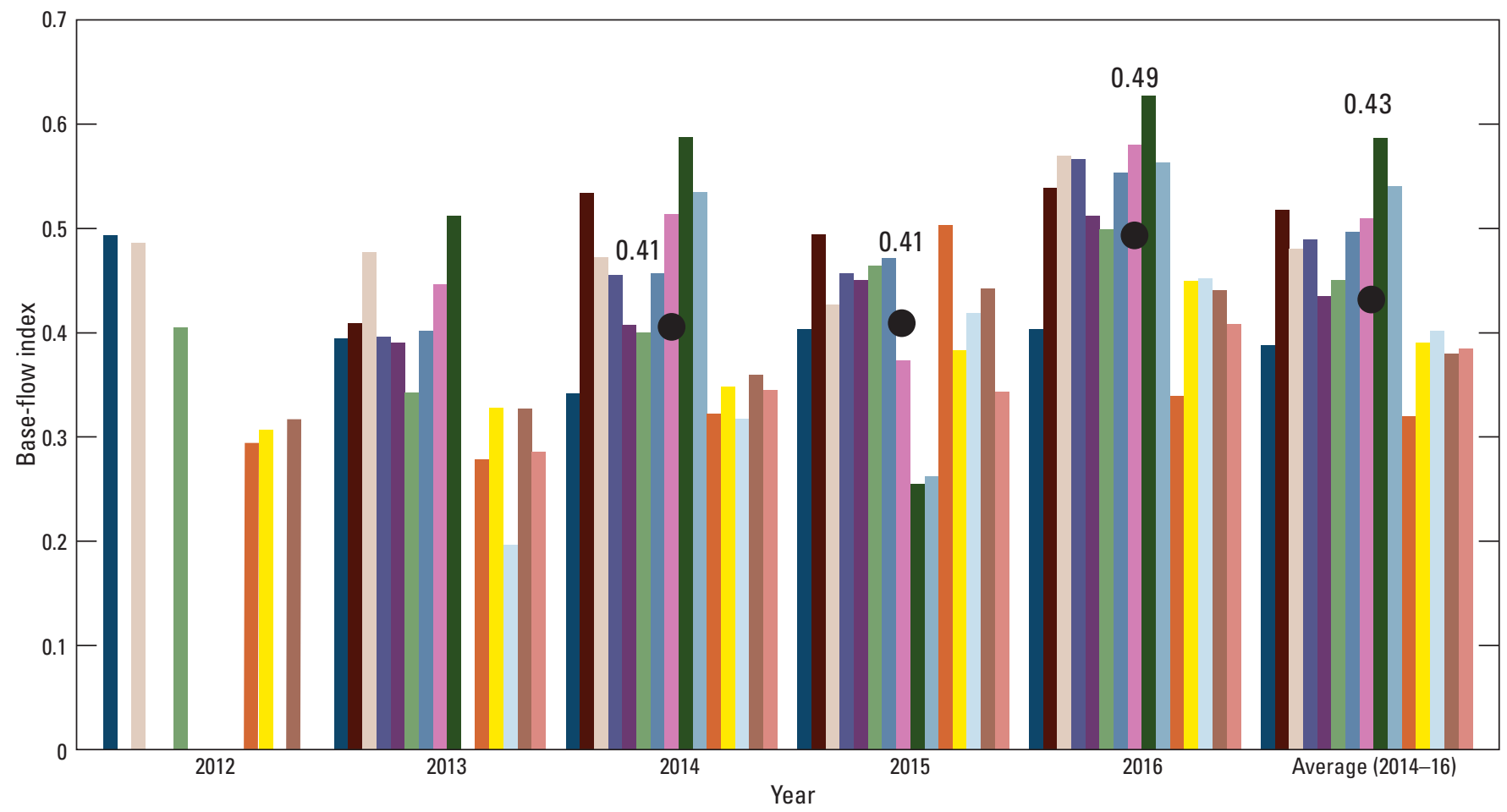

EXPLANATION

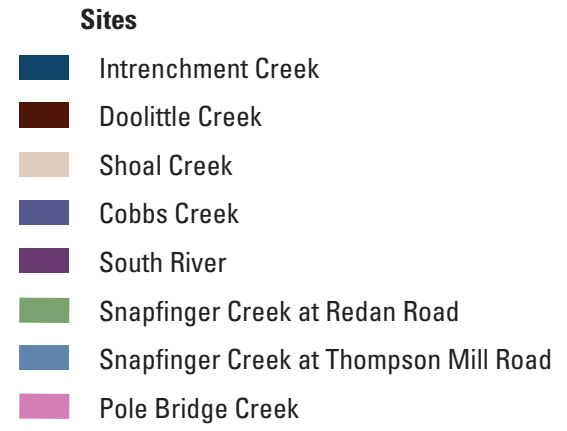

Figure 18. Annual base-flow index for 15 monitored watersheds in DeKalb County, Georgia, 2012-16.

\section{Surface-Water Quality}

Surface-water quality was assessed from in situ waterquality monitors, base-flow samples, and storm-composite samples. An example evaluation of the in situ data at one site was used to illustrate how water-quality conditions can vary seasonally, diurnally, and during storms. Base-flow and stormflow sample concentrations are presented in box plots by site to illustrate their variability and to enable comparisons. Water-quality standards are presented to provide context to the observed concentrations. Regression models for E. coli are presented, and the frequency of potential health risks of waterbased recreational activities due to fecal coliform bacteria is assessed.

\section{In Situ Water-Quality Monitoring}

Sonde turbidity, water temperature, sonde SC, dissolved oxygen (DO), and sonde $\mathrm{pH}$ were measured in situ at the 15 USGS water-quality monitoring sites in the study area (table 1) at 15-minute intervals. An evaluation of how these constituents vary temporally is presented by using data from the North Fork Peachtree Creek site. The in situ measurements provide a more complete picture of water-quality conditions seasonally, diurnally, and during storms than can be observed from the discrete base-flow and storm-composite samples. An example of in situ data is shown for the North Fork Peachtree Creek site (figs. 23-25). The water-quality variations in 


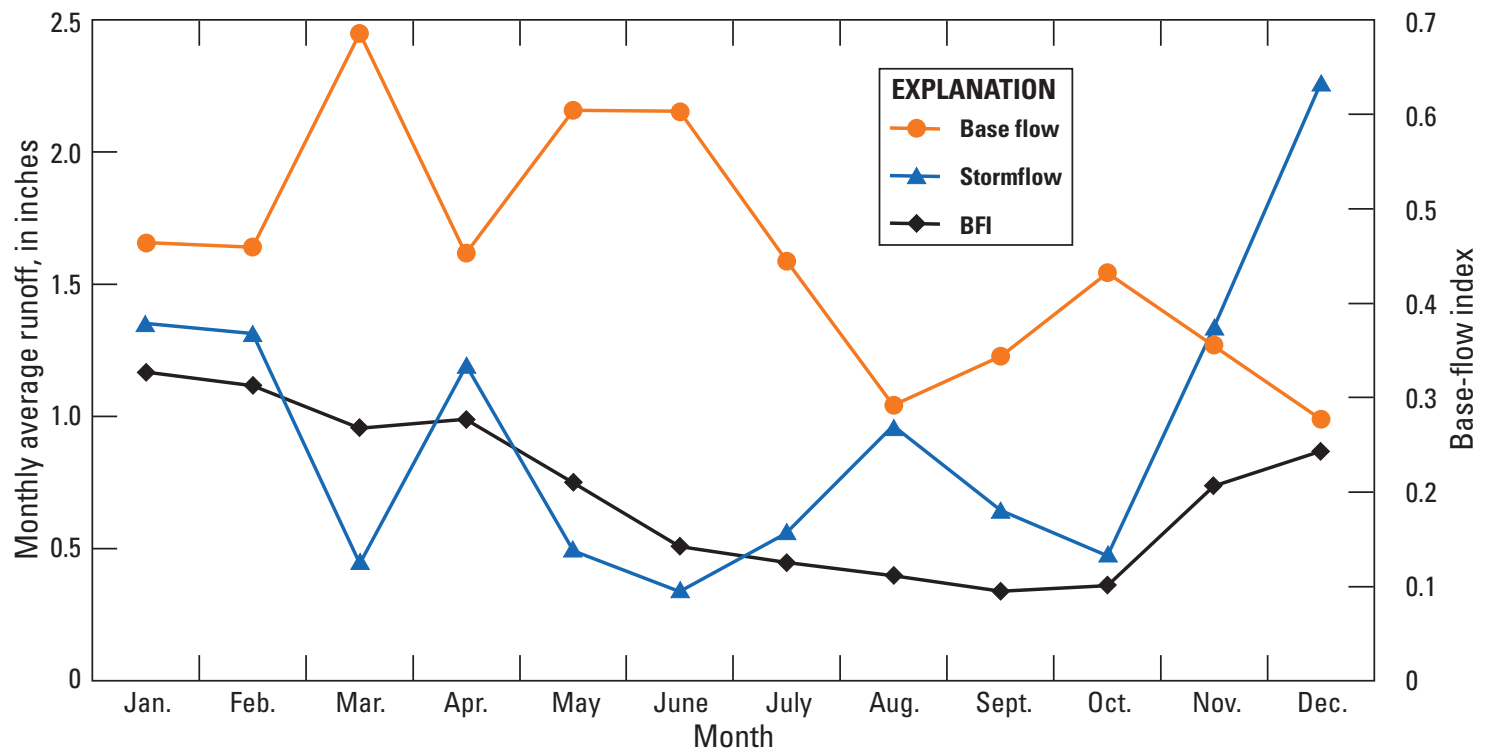

Figure 19. Monthly average base-flow runoff and stormflow runoff and the base-flow index (BFI) for the area of the monitored watersheds in DeKalb County, Georgia, 2014-16.

Table 11. Correlation coefficients between watershed characteristics and runoff metrics for 15 monitored watersheds in DeKalb County, Georgia, 2014-16.

[na, not applicable; ft, foot; - , results not listed for duplicative combinations; Statistically significant Pearson product-moment correlation coefficients in bold font ( $p$-value is less than or equal to 0.05)]

\begin{tabular}{|c|c|c|c|c|c|c|}
\hline \multirow[b]{2}{*}{ Watershed characteristic } & \multicolumn{6}{|c|}{ Runoff metric } \\
\hline & Precipitation & Runoff & $\begin{array}{c}\text { Runoff } \\
\text { ratio }\end{array}$ & Base-flow runoff & $\begin{array}{l}\text { Stormflow } \\
\text { runoff }\end{array}$ & $\begin{array}{l}\text { Base-flow } \\
\text { index }\end{array}$ \\
\hline Average land-surface slope & na & -0.251 & -0.304 & -0.041 & -0.203 & 0.177 \\
\hline Basin area & na & 0.207 & 0.150 & -0.083 & 0.236 & -0.206 \\
\hline Percent developed imperviousness & na & 0.517 & 0.646 & -0.637 & 0.844 & -0.898 \\
\hline $\begin{array}{l}\text { Percent developed imperviousness } \\
\text { within } 100 \text {-ft stream buffer }\end{array}$ & na & 0.441 & 0.613 & -0.539 & 0.689 & -0.755 \\
\hline $\begin{array}{l}\text { Percent developed imperviousness } \\
\text { within } 200 \text {-ft stream buffer }\end{array}$ & na & 0.449 & 0.632 & -0.586 & 0.723 & -0.806 \\
\hline Topographic wetness index & na & 0.131 & -0.128 & 0.233 & -0.020 & 0.151 \\
\hline Precipitation & 1 & - & - & - & - & - \\
\hline Runoff & 0.151 & 1 & - & - & - & - \\
\hline Runoff ratio & -0.163 & 0.920 & 1 & - & - & - \\
\hline Base-flow runoff & 0.767 & 0.156 & -0.098 & 1 & - & - \\
\hline Stormflow runoff & -0.317 & 0.812 & 0.890 & -0.450 & 1 & - \\
\hline Base-flow index & 0.560 & -0.513 & -0.687 & 0.762 & -0.915 & 1 \\
\hline
\end{tabular}

the example data do not reflect the full range of patterns observed because patterns vary with location, storm dynamics, and season.

Turbidity is a measure of how cloudy or opaque water is and is the result of the amount and type of suspended and dissolved matter in the water (for example, clay, silt, finely divided organic matter, plankton and other microscopic organisms, organic acids, and dyes; Anderson, 2005) and can be affected by the color of the water. Turbidity is commonly used as a surrogate for suspended sediment (Jastram and others, 2009; Rasmussen and others, 2009). Turbidity increased with increases in streamflow (fig. 23A) with no distinct diurnal variations (fig. 24A). Increases in sonde turbidity during storms did not coincide exactly with increases in streamflow; 

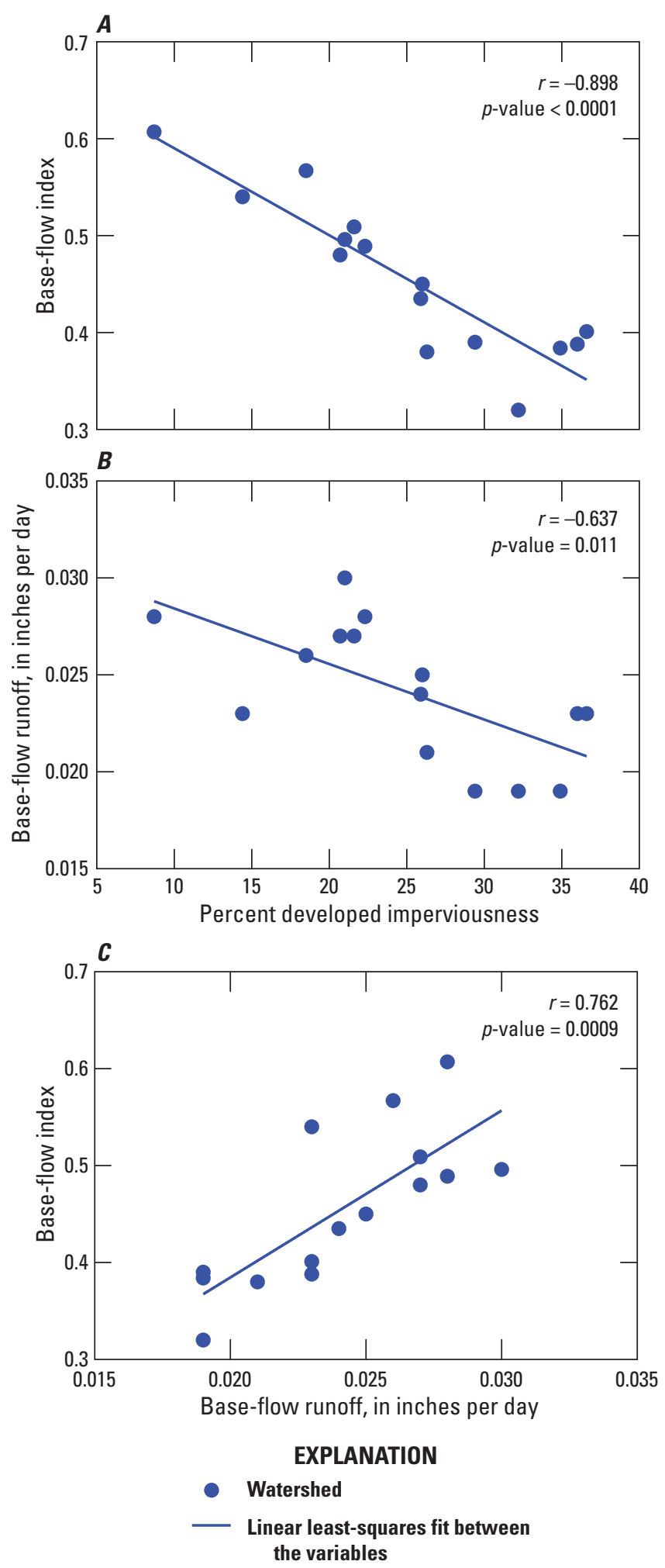

Figure 20. Scatterplots showing $A$, base-flow index (BFI) versus percent developed imperviousness, $B$, base-flow runoff versus percent developed imperviousness, and $C, B F I$ versus base-flow runoff for 15 watersheds in DeKalb County, Georgia, 2014-16. Abbreviations: $r$, Pearson product-moment correlation coefficient; $p$-value, measure of statistical significance of correlation coefficient; $<$, less than. turbidity peaked after streamflow peaked, and turbidities were higher during much of the hydrograph recession than on the rising limb for the same streamflows (fig. 25A).

Water temperature regulates the rate of chemical and biological reactions and determines the maximum amount of DO saturation. The temperature regime also determines the types of aquatic life a stream can support. Water temperature varied seasonally (fig. 23B) and diurnally (fig. 24B) because of the effects of air temperature and solar radiation. Temperature changed with inputs of storm runoff (fig. 25B) which can increase or decrease temperature depending upon the seasonal differences in temperature between storm runoff and base flow and that of the surfaces from which precipitation runs off (figs. 23A and $B$ ).

$\mathrm{SC}$ reflects the concentration of dissolved constituents in a water sample. SC typically decreased with increasing streamflow (figs. $23 A$ and $B$ ) and stormflow (figs. $25 A$ and $B$ ), indicating that, overall, dissolved constituents tended to dilute at higher streamflows. SC exhibited a weak diurnal pattern in this example, with higher SC measured in the morning (fig. 24B).

Surface waters obtain oxygen by direct absorption from the atmosphere, and absorption is enhanced by aeration from turbulence. Low DO can be an indication of pollution and can affect the growth and reproduction of aerobic aquatic species. Concentrations of DO can change with temperature, streamflow, nutrient inputs, and plant growth (EPA, 2017). Excess nutrients and associated excessive plant growth can deplete oxygen through aerobic respiration and decomposition when plants die. The EPA has set a freshwater warmwater DO criteria for a 1-day minimum concentration of $5.0 \mathrm{mg} / \mathrm{L}$ for early life stages and $3.0 \mathrm{mg} / \mathrm{L}$ for other life stages of aquatic life (EPA, 1986). In the example at the North Fork Peachtree Creek site, DO was highest in the winter and lowest in the summer (fig. 23C). A strong diurnal pattern is evident, with DO concentrations at their highest at midday (fig. 24C), likely reflecting the release of oxygen from plant (for example, periphyton) photosynthesis. DO was also higher during stormflow (fig. 25C), likely the result of increased aeration during higher discharge.

The acidity or basicity of water is represented as $\mathrm{pH}$. In the example, $\mathrm{pH}$ was lower in the summer and early fall (fig. 23C). pH exhibited a diurnal pattern, with the highest $\mathrm{pH}$ values occurring in the afternoon (fig. 24C). During storms, $\mathrm{pH}$ was lower, indicating more acidic conditions during stormflow (fig. $25 \mathrm{C}$ ). Seasonal $\mathrm{pH}$ patterns can result from seasonal variations in hydrologic controls (Soulsby and others, 2001) and concentrations of 

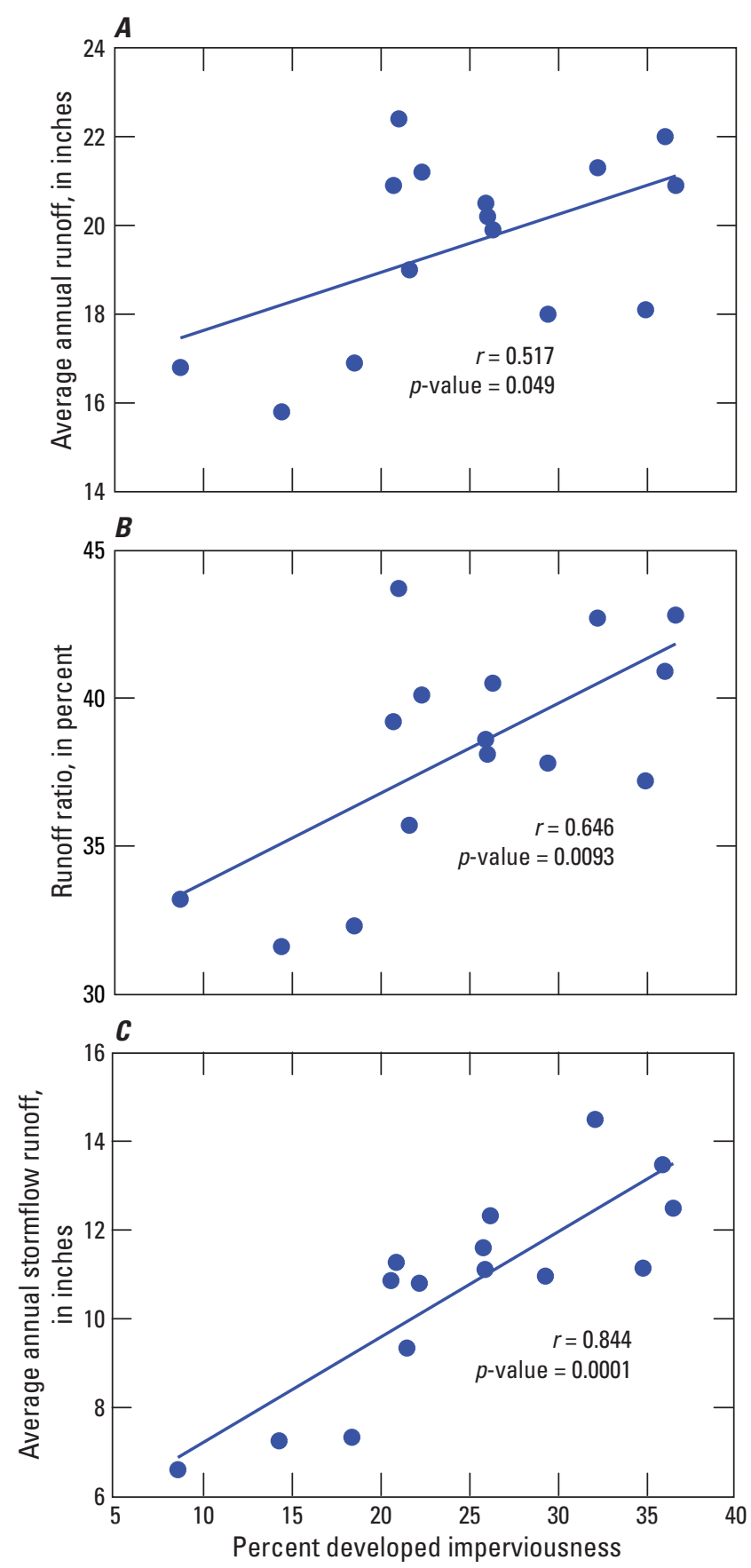

EXPLANATION

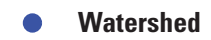

_ Linear least-squares fit between the variables

Figure 21. Scatterplots showing $A$, average annual runoff, $B$, runoff ratio, and $C$, average annual stormflow runoff versus percent developed imperviousness for 15 watersheds in DeKalb County, Georgia, 2014-16. Abbreviations: $r$, Pearson product-moment correlation coefficient; $p$-value, measure of statistical significance of correlation coefficient. organic acids that affect the acid-base status of waters. Higher pHs during the day can be the result of photosynthesis in the stream, which consumes hydrogen ions and raises $\mathrm{pH}$ (Porter and others, 2020). Streamwater $\mathrm{pH}$ is lower (more acidic) during storms because of contributions of more acidic stormflow from precipitation and shallow flowpaths compared to base flow that comes from more basic deeper groundwater.

\section{Base-Flow and Stormflow Water Quality}

Box plots were used to summarize the statistical distribution of concentrations for 22 water-quality constituents, and concentrations were separated by base-flow and stormflow conditions, depending on when samples were collected (fig. 26; table 4). The following descriptions of the concentration ranges refer to the approximate range of the concentrations within the whiskers of the box-and-whisker plots for most of the sites and not to the concentrations designated as outliers.

Sonde $\mathrm{SC}$ ranged from about 70 to 170 microsiemens per centimeter at 25 degrees Celsius $\left(\mu \mathrm{S} / \mathrm{cm}\right.$ at $\left.25^{\circ} \mathrm{C}\right)$ in base-flow samples and from about 40 to $140 \mu \mathrm{S} / \mathrm{cm}$ in stormflow samples when excluding Intrenchment Creek (fig. 26A). Intrenchment Creek base-flow conductivities (205 to $240 \mu \mathrm{S} / \mathrm{cm}$ ) were consistently higher than the range in values observed at the other sites. Excluding Intrenchment Creek, the four sites with the highest $\mathrm{SC}$ values under base-flow conditions (South River, North Fork Peachtree Creek, South Fork Peachtree Creek at Johnson Road, and Nancy Creek) represented four of the six largest drainage areas. SC values were significantly lower in stormflow samples than in base-flow samples for all sites, reflecting the contributions of more dilute stormflow to base flow. Base flow had higher conductivities because of higher concentrations of weathering constituents associated with longer contact times with geological materials. Sites with higher stormflow conductivities generally also had higher base-flow conductivities.

Biochemical oxygen demand (BOD) is the amount of dissolved oxygen needed by aerobic organisms to break down the amount of organic material in a sample over a specific time period ( 5 days) and water temperature $\left(20^{\circ} \mathrm{C}\right)$ and is an indication of the degree of organic pollution in surface waters. BOD represents the potential consumption of oxygen by microbial respiration, whereas the actual rate of consumption depends on several factors including water temperature, $\mathrm{pH}$, microorganisms present, and types of organic material. BOD concentrations ranged from nondetection $(<0.24 \mathrm{mg} / \mathrm{L})$ to $5 \mathrm{mg} / \mathrm{L}$ (of oxygen consumed) in base-flow samples and from 2 to $20 \mathrm{mg} / \mathrm{L}$ in stormflow samples (fig. 26B). Concentrations of BOD were significantly higher in stormflow samples than in base-flow samples from all sites except Stone Mountain Creek. Stormflow BOD was highest at Intrenchment Creek and lowest at Stone Mountain Creek. 


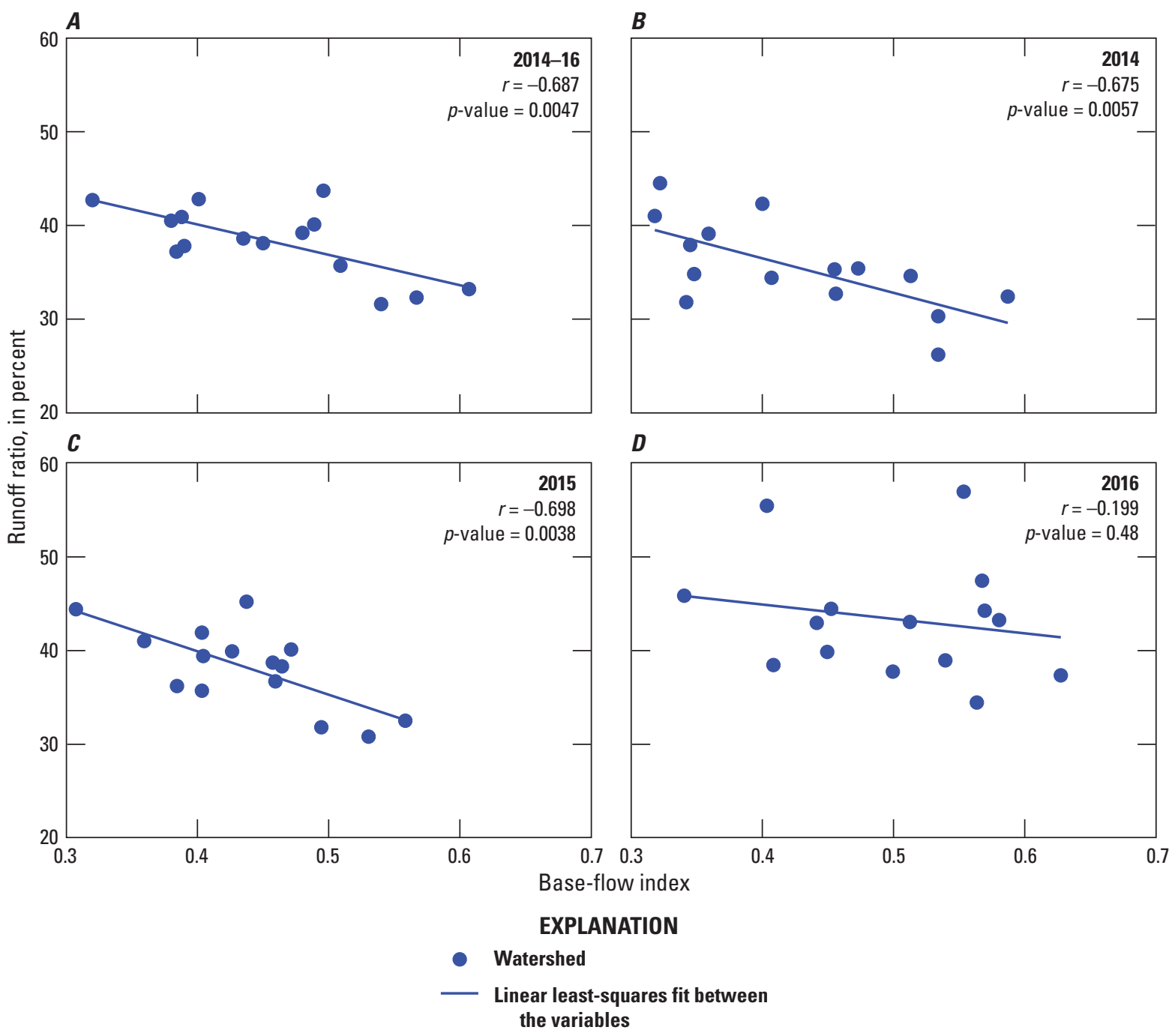

Figure 22. Scatterplots showing runoff ratio versus base-flow index for $A$, 2014 to 2016, B, 2014, $C, 2015$, and D, 2016 for 15 watersheds in DeKalb County, Georgia. Abbreviations: $r$, Pearson product-moment correlation coefficient; $p$-value, measure of statistical significance of the correlation coefficient.

Chemical oxygen demand (COD) is the amount of oxygen needed to fully oxidize organic compounds to carbon dioxide and is a measure of oxidizable pollutants in surface waters. COD represents the potential consumption of oxygen by chemical oxidation. COD concentrations ranged from nondetection $(<4.1 \mathrm{mg} / \mathrm{L}$ ) to $30 \mathrm{mg} / \mathrm{L}$ (of oxygen consumed) in base-flow samples and from 8 to $200 \mathrm{mg} / \mathrm{L}$ in stormflow samples, except at Stone Mountain Creek where concentrations were higher in base-flow samples than in stormflow samples (fig. 26C). Concentrations of COD were significantly higher in stormflow samples than in base-flow samples from 12 of the sites.

Sonde $\mathrm{pH}$ ranged from about 6.3 to 7.8 across all sites (fig. 26D), reflecting neutral acid-base conditions. Ranges were similar among sites and between base-flow and stormflow samples, with a few deviations such as at Doolittle Creek and Pole Bridge Creek (significantly higher during stormflows) and Snapfinger Creek at Thompson Mill Road (significantly higher during base flows). Several stormflow samples had $\mathrm{pH}$ values below the acute national recommended aquatic life criteria of 6.5 (EPA, 2017).

Turbidity ranged from about 0.8 to $7 \mathrm{FNU}$ in base-flow samples and from about 10 to $600 \mathrm{FNU}$ in stormflow samples across all sites (fig. 26E). Stormflow turbidities were significantly higher than base-flow turbidities for all sites, as would be expected because the higher streamflow velocities and energy available during stormflow mobilize particulates. The range in turbidity during stormflows was similar across sites with the exception of Stone Mountain Creek where values were considerably lower.

Sediments account for more water-quality impairments than any other pollutant in the United States (EPA, 2003). Excess sediment in surface waters can disrupt aquatic habitats, reduce aquatic plant growth, reduce fish populations, fill 

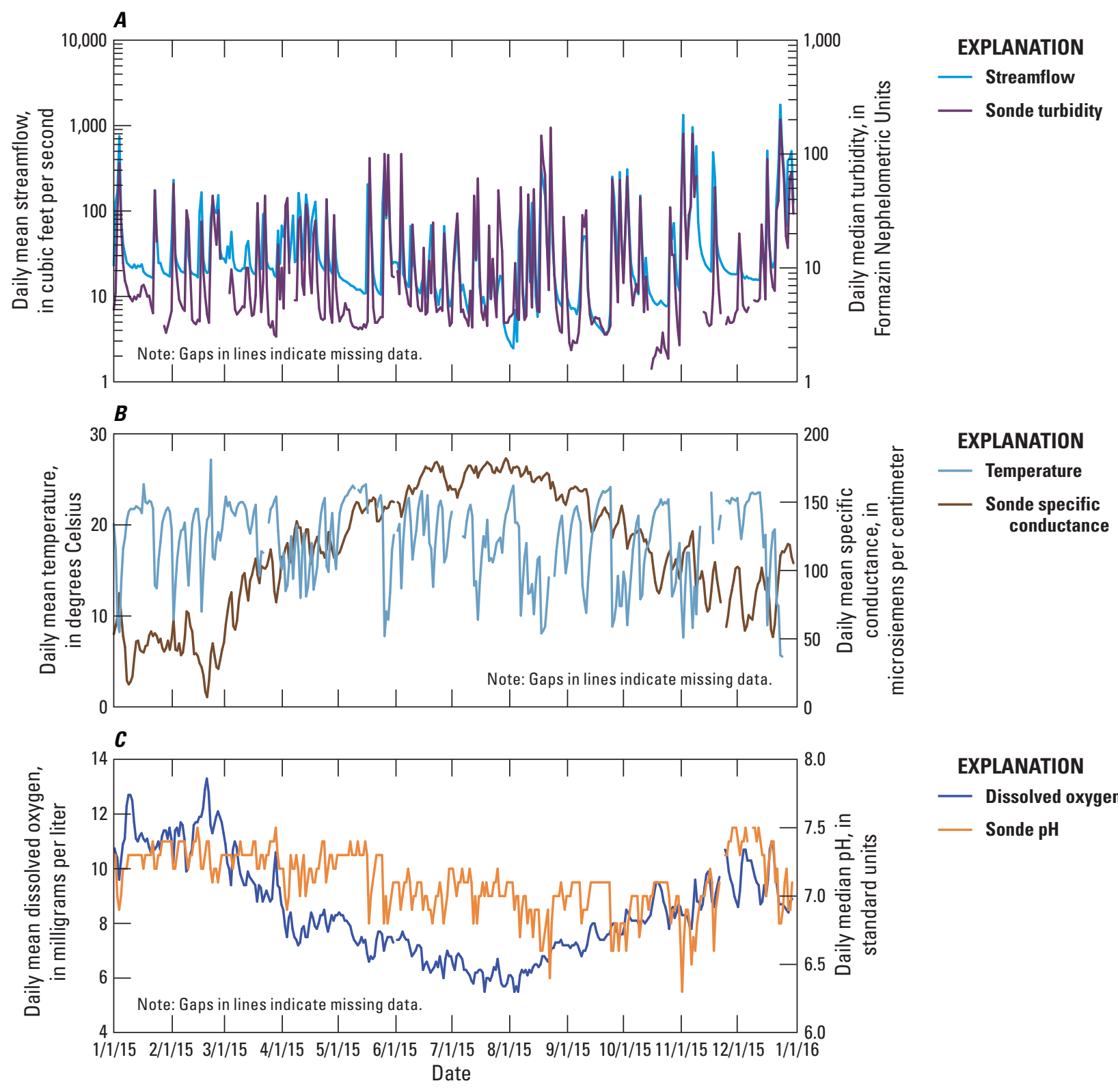

\section{EXPLANATION}

- Dissolved oxygen

Sonde $\mathrm{pH}$

Figure 23. Streamflow and in situ water-quality monitoring data from the North Fork Peachtree Creek site (U.S. Geological Survey site 02336120) showing seasonal variations for 2015. $A$, Daily mean streamflow and median turbidity, $B$, daily mean temperature and mean specific conductance, and $C$, daily mean dissolved oxygen and median $\mathrm{pH}$. Dates are in month/day/ year format.

storm drains and catch basins, and increase the cost of water treatment. Total suspended sediment (TSS) concentrations ranged from about 1 to $8 \mathrm{mg} / \mathrm{L}$ in base-flow samples and from about 5 to $1,000 \mathrm{mg} / \mathrm{L}$ in stormflow samples (fig. 26F). Concentrations in stormflow samples were about two orders of magnitude higher than in base-flow samples. The ranges of TSS concentrations were similar for most sites. The Stone Mountain Creek site had notably lower TSS concentrations during stormflow than the other sites. The large reservoir in its drainage area trapped sediment from a substantial portion of the basin and limited downstream sediment transport due to moderated stormflow. Base-flow samples were only regularly analyzed for SSC at five of the sites because concentrations at the other sites were proven to be low during these conditions. Stormflow SSCs were somewhat higher than stormflow TSS concentrations and ranged from about 10 to 2,000 mg/L (fig. 26G), but the relative differences in TSS and SSC between sites were consistent. The higher SSC versus TSS concentrations are consistent with what has been reported in an adjacent county's water-quality study (Gwinnett County; Landers and others, 2007; Landers, 2013; Joiner and others, 2014; Aulenbach and others, 2017a). TSS concentrations can 

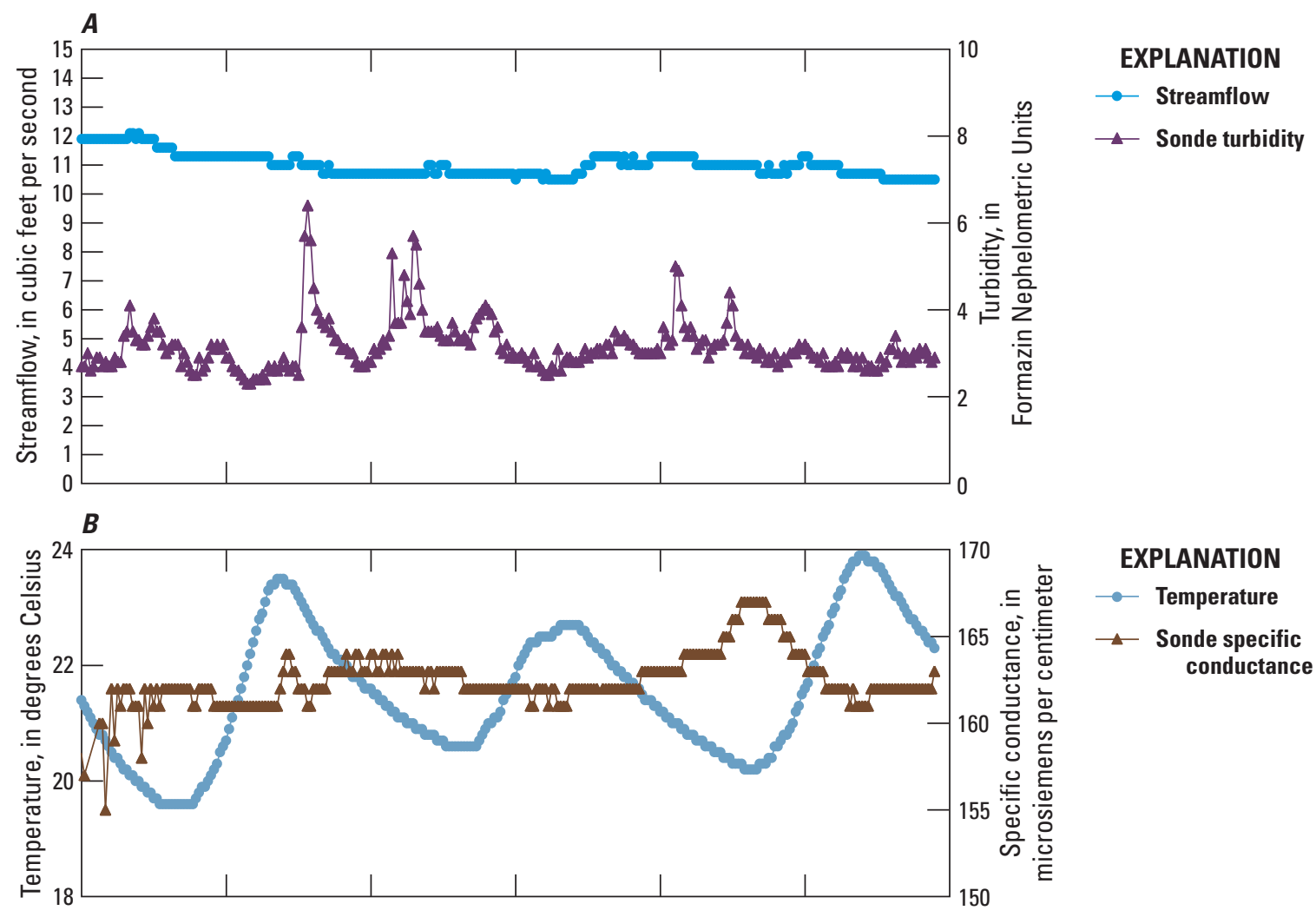

\section{EXPLANATION}

- Temperature

$\neg$ Sonde specific conductance

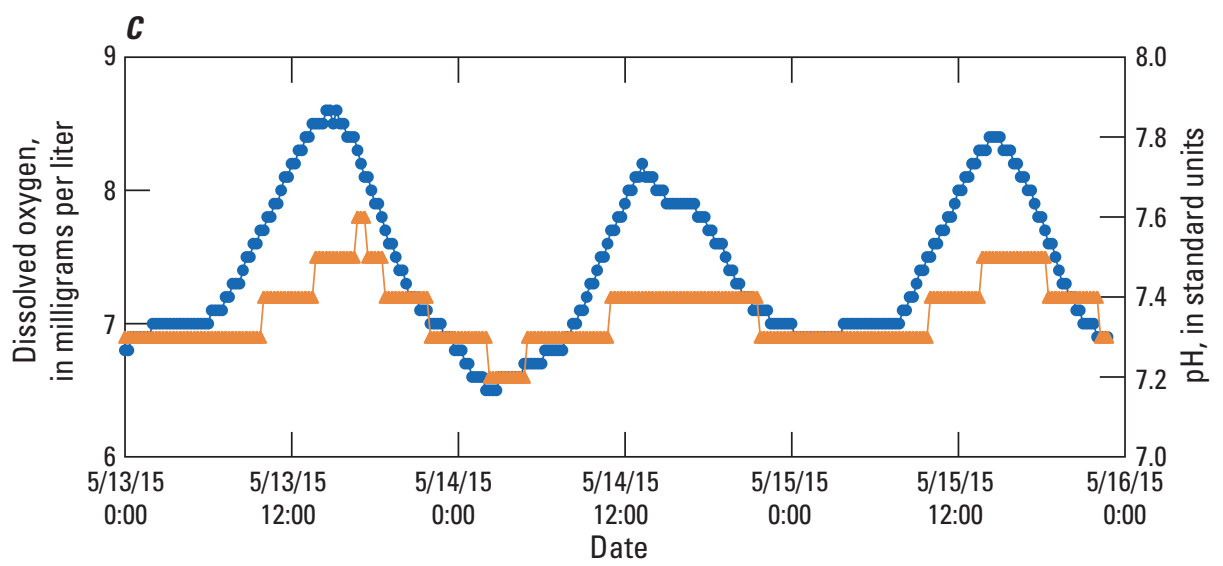

EXPLANATION

$\multimap$ Dissolved oxygen

$\rightarrow$ Sonde $\mathrm{pH}$

Figure 24. Streamflow and in situ water-quality monitoring data from the North Fork Peachtree Creek site (U.S. Geological Survey site 02336120) showing diurnal variations, May 13-15, 2015. A, Streamflow and turbidity, $B$, temperature and specific conductance, and $C$, dissolved oxygen and $\mathrm{pH}$. Times are in Eastern Standard Time. Dates are in month/day/year format.

underrepresent actual suspended sediments because of the analytical methodology, particularly when sediments contain more than 25 percent sand (the coarser portion of the sediment; Gray and others, 2000; Landers, 2013).

Nutrients, such as nitrogen and phosphorus, are necessary for growth of aquatic plants. However, excess nutrients can lead to eutrophication inducing excessive growth of algae and corresponding reductions in dissolved oxygen levels that can be detrimental to the health and survival of aquatic organisms. Total nitrogen (TN) concentrations ranged from nondetection
$(<0.2 \mathrm{mg} / \mathrm{L}$ as $\mathrm{N}$ ) to $4 \mathrm{mg} / \mathrm{L}$ as $\mathrm{N}$ (fig. $26 H$ ). The ranges in TN concentrations were similar between stormflows and base flows at all sites except for South Fork Peachtree Creek at Casa Drive, South Fork Peachtree Creek at Johnson Road, and Nancy Creek, where concentrations in stormflow samples were significantly greater than in base-flow samples. TN concentrations were generally lowest at Stone Mountain Creek during base-flow and stormflow conditions. TN concentrations were mostly above the ambient water-quality potential reference condition of $0.411 \mathrm{mg} / \mathrm{L}$ as N (EPA, 2000a). 

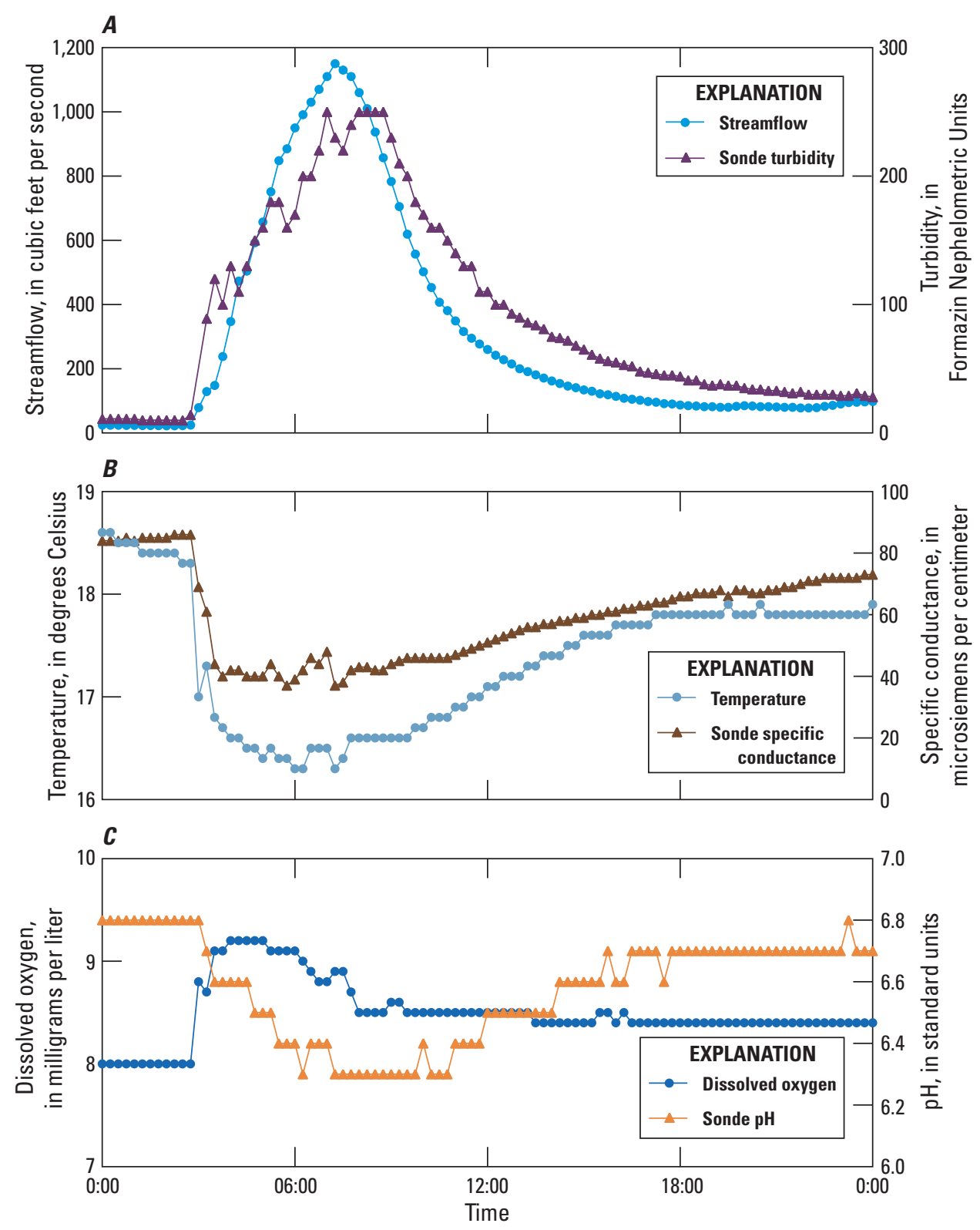

Figure 25. Streamflow and in situ water-quality monitoring data from the North Fork Peachtree Creek site (U.S. Geological Survey site 02336120) showing response to a storm on October 3 , 2015. $A$, Streamflow and turbidity, $B$, temperature and specific conductance, and $C$, dissolved oxygen and $\mathrm{pH}$. Times are in Eastern Standard Time.

Total nitrate plus nitrite $\left(\mathrm{NO}_{3}+\mathrm{NO}_{2}\right)$ concentrations ranged from nondetection $(<0.01 \mathrm{mg} / \mathrm{L}$ as $\mathrm{N})$ to $2 \mathrm{mg} / \mathrm{L}$ as $\mathrm{N}$ in base-flow samples and from about $<0.01$ to $1 \mathrm{mg} / \mathrm{L}$ as $\mathrm{N}$ in stormflow samples (excluding Stone Mountain Creek; fig. 261). Concentrations in base-flow samples were significantly higher than in stormflow samples from 9 of the 15 sites, indicating dilution, whereas the other sites had similar concentrations in base-flow and stormflow samples. Base-flow $\mathrm{NO}_{3}+\mathrm{NO}_{2}$ concentrations were highest at the Intrenchment Creek, Doolittle Creek, and Little Stone Mountain Creek sites, with the latter two having two of the three smallest drainage areas in the study. Stone Mountain Creek $\mathrm{NO}_{3}+\mathrm{NO}_{2}$ concentrations were notably lower than the concentrations at the other sites and contributed to the low TN concentrations observed at this site (fig. 26H). The low $\mathrm{NO}_{3}+\mathrm{NO}_{2}$ concentrations may have been caused by in-lake processes, such as denitrification and microbial assimilatory nitrate reduction of dissolved nitrate (which is likely the predominant component of this constituent), in the large reservoir in this watershed. This reduction in $\mathrm{NO}_{3}+\mathrm{NO}_{2}$ is substantiated in that the Little Stone Mountain Creek watershed, a subbasin of Stone Mountain Creek upstream of the reservoir, has among the 


\section{Interpreting Box-and-Whisker Plots}

The box-and-whisker plots in figures 26 and 27 illustrate the range and distribution of sample concentrations for each watershed and sampling flow condition. The top and bottom of the "box" (rectangle) represents the 75th and 25th quartiles of sample concentrations, respectively, and the line within the box represents the 50th percentile (median) sample concentration. The "whiskers" (lines extending above and below the box) represent the range of sample concentrations that are within 1.5 times the interquartile range above or below the box. (The range of the box represents one interquartile.) Concentrations that are outside the possible range of the whiskers are defined as outliers and are plotted individually. Concentrations for constituents are plotted on a log scale when they exhibit a normal distribution in log space. If the concentration is below its LRL (table 4), the magnitude of its LRL, or its estimated value if available, is used to create the box-andwhisker plots. For this study, all sample concentrations were plotted, including values that were excluded as outliers for the development of the load estimation models. Significant differences between watershed base-flow and stormflow sample concentration distributions were determined by using the nonparametric Mann-Whitney U test (also called the Wilcoxon rank-sum test) with a significance level of $p$-value $\leq 0.05$. In this test, values were ranked based on their magnitudes with no considerations made for their censored state. particulate form and sediment-related nature of TP. TP concentrations at the Stone Mountain Creek site were low in base-flow samples and the lowest of all sites' TP concentrations in stormflow samples. This was likely due to the large reservoir in its drainage that may have minimized sediment transport from a substantial portion of the basin. Baseflow TP concentrations were near the ambient waterquality potential reference condition of $0.030 \mathrm{mg} / \mathrm{L}$ as $\mathrm{P}$ (EPA, 2000a). This is somewhat consistent with the findings of Journey and others (2018) that TP concentrations were below the ambient levels for wadeable urban streams in the Atlanta area. Concentrations in stormflow highest $\mathrm{NO}_{3}+\mathrm{NO}_{2}$ concentrations in base-flow and stormflow samples, while the Stone Mountain Creek site had no evidence of high $\mathrm{NO}_{3}+\mathrm{NO}_{2}$ concentrations. With the exception of Stone Mountain Creek, $\mathrm{NO}_{3}+\mathrm{NO}_{2}$ concentrations were mostly above the ambient water-quality potential reference condition of $0.177 \mathrm{mg} / \mathrm{L}$ as N (EPA, 2000a). Higher-thanambient $\mathrm{NO}_{3}+\mathrm{NO}_{2}$ concentrations are consistent with the findings of Journey and others (2018) for urban streams in the Southeastern United States.

Total ammonia plus organic nitrogen (TKN) concentrations ranged from nondetection $(<0.18 \mathrm{mg} / \mathrm{L}$ as $\mathrm{N})$ to $3 \mathrm{mg} / \mathrm{L}$ as $\mathrm{N}$ (fig. 26J). During base-flow conditions, concentrations of TKN and $\mathrm{NO}_{3}+\mathrm{NO}_{2}$ are similar in magnitude, whereas TKN is the predominant component of TN during stormflow conditions. TKN concentrations were significantly higher in stormflow samples than in base-flow samples from 13 of the sites. Concentrations were mostly above the ambient waterquality potential reference condition of $0.234 \mathrm{mg} / \mathrm{L}$ as N (EPA, 2000a). Dissolved ammonia $\left(\mathrm{NH}_{3}\right)$ concentrations ranged from about 0.02 to $0.7 \mathrm{mg} / \mathrm{L}$ as N (fig. $26 \mathrm{~K}$ ). The lower concentrations relative to TKN indicate that the predominant component of TKN is the organic portion, particularly during stormflow conditions. $\mathrm{NH}_{3}$ concentrations were significantly higher in stormflow samples than in base-flow samples for seven of the sites.

Base-flow total phosphorus (TP) concentrations ranged from nondetection $(<0.005 \mathrm{mg} / \mathrm{L}$ as $\mathrm{P})$ to $0.1 \mathrm{mg} / \mathrm{L}$ as $\mathrm{P}$ (fig. 26L). TP concentrations ranged from about 0.02 to $0.5 \mathrm{mg} / \mathrm{L}$ as $\mathrm{P}$ in stormflow samples, about one order of magnitude higher than in base-flow samples. TP concentrations were significantly higher in stormflow samples than in baseflow samples from all sites. This reflects the predominantly samples were mostly above this reference condition, whereas the Stone Mountain Creek stormflow TP concentrations were near this reference condition. TP concentrations were often greater than $0.1 \mathrm{mg} / \mathrm{L}$ as $\mathrm{P}$ in stormflow samples, which is the threshold at which TP concentrations are considered to be able to support nuisance levels of algal production in flowing waters (EPA, 2000a). Dissolved phosphorus (DP) concentrations ranged from about 0.005 to $0.1 \mathrm{mg} / \mathrm{L}$ as $\mathrm{P}$ (fig. $26 M$ ). The range in concentrations was similar between stormflow and base-flow samples at most sites; however, five sites had significantly higher stormflow DP concentrations than baseflow DP concentrations.

Total organic carbon (TOC) represents the amount of organic matter in water and is an indication of organic pollution. TOC is related to BOD and COD; however, TOC is a measurement of the amount of carbon in organic matter independent of its oxidation state, whereas BOD and COD represent the amount of oxygen consumed to fully reduce the organic matter to its lowest oxidation state. TOC concentrations ranged from about 1 to $4 \mathrm{mg} / \mathrm{L}$ as $\mathrm{C}$ in base-flow samples and from 3 to $15 \mathrm{mg} / \mathrm{L}$ as $\mathrm{C}$ in stormflow samples (fig. 26N). Concentrations in base-flow samples were lowest at the Doolittle Creek, Cobbs Creek, and Little Stone Mountain Creek sites, which have three of the five smallest drainage areas in the study. Concentrations in stormflow samples were significantly higher and more similar among sites than the concentrations in base-flow samples. Concentrations in stormflow samples were about half an order of magnitude higher than in base-flow samples except for the Stone Mountain Creek site, where concentrations were similar. At Stone Mountain Creek, TOC concentrations were higher during base 


\section{Interpreting Water-Quality Standards}

Various types of water-quality standards have been adopted for constituents that are considered toxic or detrimental at high concentrations, such as trace metals, nutrients, and bacteria. These standards have been included on figures 26 and 27 to provide context to the observed sample concentrations. Criteria often have a time-element to them such that the concentration of a single sample above a criterion does not necessarily indicate a criterion exceedance.

The EPA (2017) has determined national recommended aquatic life ambient water-quality criteria for toxic chemicals and conditions. Georgia has adopted these water-quality standards to comply with the Clean Water Act (EPA, 2015). These criteria represent the highest constituent concentration that is not expected to pose a significant risk to the majority of species in a given environment or that will ensure that a water body is free from certain negative conditions (EPA, 2017). Criteria were determined for acute and chronic conditions, where acute is for a short period of time (1-hour average) and chronic is for an extended period of time (4-day average), for which aquatic life can be exposed without deleterious effects. For $\mathrm{pH}$, the acute aquatic life criteria require that $\mathrm{pH}$ values be between 6.5 and 9 . The criteria for total lead, total zinc, total copper, and total cadmium are dependent on the hardness of the water. Hardness is the sum of the dissolved concentrations of calcium and magnesium and is expressed in units of milligrams per liter as calcium carbonate $\left(\mathrm{CaCO}_{3}\right)$. The median hardness values for samples collected in this study were about $24 \mathrm{mg} / \mathrm{L}$ as $\mathrm{CaCO}_{3}$ for the stormflow samples and $32 \mathrm{mg} / \mathrm{L}$ as $\mathrm{CaCO}_{3}$ for the base-flow samples. Median hardness was calculated from the median concentrations of total calcium and magnesium from samples collected for all study watersheds (figs. $26 O$ and $P$ ). This assumed that most of the total calcium and magnesium was in its dissolved form. The trace metals criteria presented in figs. $26 Q-U$ were calculated by using the freshwater acute and chronic formulas for total metals concentrations and the approximate median hardness of the stormflow and base-flow samples, respectively. These criteria used herein are lower than EPA criteria published in tables for a set hardness of 100 or $50 \mathrm{mg} / \mathrm{L}$ as $\mathrm{CaCO}_{3}$ for dissolved constituents (EPA, 2017). Site-specific copper criteria using the biotic ligand model were not calculated. These criteria should be used only as a guide for possible exceedance of water-quality standards, because (1) chronic and acute criteria have defined time-period requirements that individual samples do not necessarily comply with, and (2) the criteria presented were not calculated from the individual sample hardness. The effect of hardness on the criteria is demonstrated for the Intrenchment Creek site chronic criterion. Intrenchment Creek base-flow samples have a hardness of $69 \mathrm{mg} / \mathrm{L}$ as $\mathrm{CaCO}_{3}$, based on median base-flow $\mathrm{Ca}$ and $\mathrm{Mg}$ concentrations; $69 \mathrm{mg} / \mathrm{L}$ as $\mathrm{CaCO}_{3}$ was substantially higher than the hardness at the other sites. The corresponding calculated chronic criterion for total lead was $2.0 \mu \mathrm{g} / \mathrm{L}$, which was substantially higher than the $0.75-\mu \mathrm{g} / \mathrm{L}$ criterion calculated for the overall study using the median hardness of $32 \mathrm{mg} / \mathrm{L}$ as $\mathrm{CaCO}_{3}$.

The EPA (2000a) has published recommendations for establishing ambient water-quality criteria for nutrients in rivers and streams in ecoregion IX. Reference conditions, which represent pristine or minimally impacted waters, can be used as a basis for developing nutrient criteria. Potential reference conditions were calculated as the median value of the 25th percentiles from each of the four seasons. These potential reference conditions were calculated for all streams with nutrient data (not just reference streams) in level III subecoregion 45 (which includes DeKalb County) for the period 1990-99. These reference values are indicated on figs. $26 H-J$ and $L$ for total $\mathrm{N}$, total $\mathrm{NO}_{3}+\mathrm{NO}_{2}, \mathrm{TKN}$, and total $\mathrm{P}$, respectively.

Georgia has established bacterial criteria for recreational waters (EPA, 2015). From May through October, when water contact recreation is expected to occur, fecal coliform should not exceed a geometric mean of 200 colony forming units (cfu) per $100 \mathrm{~mL}$. From November through April, fecal coliform should not exceed a geometric mean of 1,000 cfu per $100 \mathrm{~mL}$ or exceed a maximum of $4,000 \mathrm{cfu}$ per $100 \mathrm{~mL}$ for any sample. The geometric mean is based on a minimum of four samples over a 30-day period at intervals not less than 24 hours. These criteria are indicated on fig. $27 B$. In addition to the designated use water-quality standards, the EPA has developed the BAV for notification of elevated levels of FIB for recreational users (EPA, 2012). The BAVs for freshwater using E. coli as the FIB are 235 and $190 \mathrm{cfu}$ per $100 \mathrm{~mL}$ for 36 and 32 cases of gastrointestinal illness per 1,000 primary contact recreators, respectively. The more commonly instituted BAV of 235 cfu per $100 \mathrm{~mL}$ is indicated on fig. $27 \mathrm{~A}$.

flow and lower during stormflow than at the other sites; this was likely attributable to the large reservoir in this watershed. Thirteen sites had their highest TOC concentrations in storm samples collected on November 29 or 30, 2016, ranging from 14 to $68 \mathrm{mg} / \mathrm{L}$; for some sites, these concentrations were several times higher than their next highest observed TOC concentrations. The other two sites, Pole Bridge Creek and Stone Mountain Creek, were not sampled during that storm. The high TOC concentrations in November 2016 likely reflect contributions of ash from wildfires (Earl and Blinn, 2003; Bodí and others, 2014) that occurred in October and November in northern Georgia and the adjacent mountains of Tennessee and North Carolina as the result of a flash drought. Smoke from these fires was observed in the study area, and the stormflow samples collected represent the first storm with appreciable rainfall in about 2 months. 

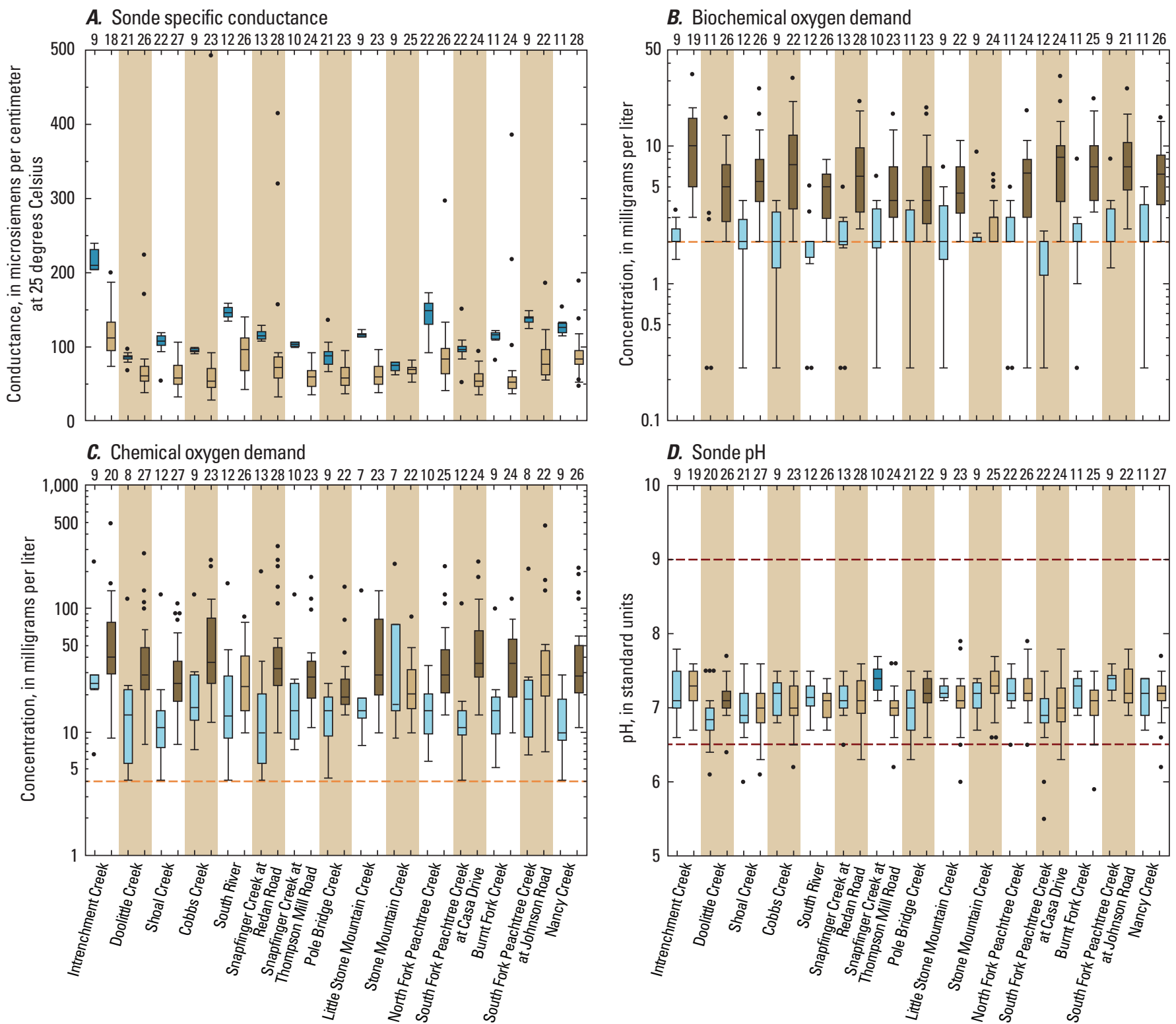

Site

EXPLANATION

\begin{tabular}{|c|c|}
\hline 19 & Number of samples \\
\hline & Outlier >1.5 IOR \\
\hline & Within $+1.5 * 10 R$ \\
\hline & 75th quantile \\
\hline & Median \\
\hline & 25th quantile \\
\hline & Within $-1.5 *$ IOR \\
\hline - & Outlier <-1.5 IQR \\
\hline & $\begin{array}{l}\text { Box plot where all concentrations } \\
\text { within the IOR are the same }\end{array}$ \\
\hline
\end{tabular}

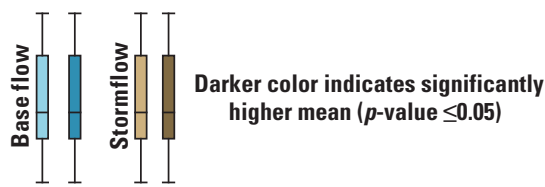
---- National recommended aquatic life criteria range ( $\mathrm{pH}$ should be between 6.5 and 9 )

(U.S. Environmental Protection Agency, 2017)

---- Predominant laboratory reporting limit

Figure 26. Base-flow and stormflow sample concentration magnitudes at 15 monitored watersheds in DeKalb County, Georgia, 2012-17. $A$, Sonde specific conductance, $B$, biochemical oxygen demand, $C$, chemical oxygen demand, $D$, sonde $\mathrm{pH}, \mathrm{E}$, laboratory turbidity, $F$, total suspended solids, $G$, suspended-sediment concentration, $H$, total nitrogen, $I$, total nitrate plus nitrite, $J$, total ammonia plus organic nitrogen, $K$, dissolved ammonia, $L$, total phosphorus, $M$, dissolved phosphorus, $N$, total organic carbon, $O$, total calcium, $P$, total magnesium, $Q$, total cadmium, $R$, dissolved cadmium, $S$, total copper, $T$, total lead, $U$, total zinc, and $V$, total dissolved solids. Significant difference between base-flow and stormflow sample concentration distributions determined from Mann-Whitney $U$ test with a $p$-value of $\leq 0.05$. Abbreviations: IQR, interquartile range; $\mathrm{mg} / \mathrm{L}$, milligrams per liter; $\mathrm{CaCO}_{3}$, calcium carbonate. 


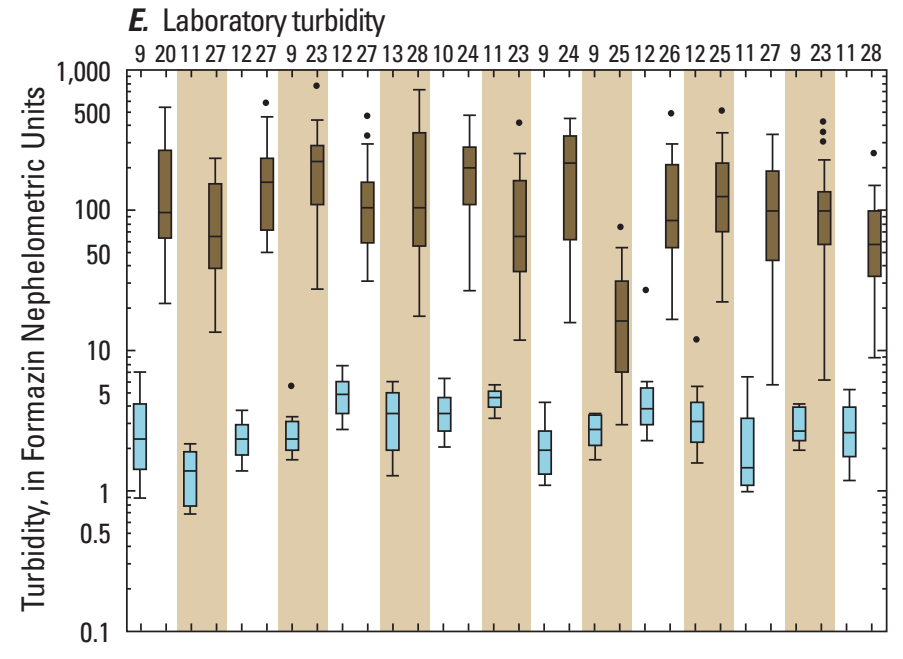

G. Suspended-sediment concentration

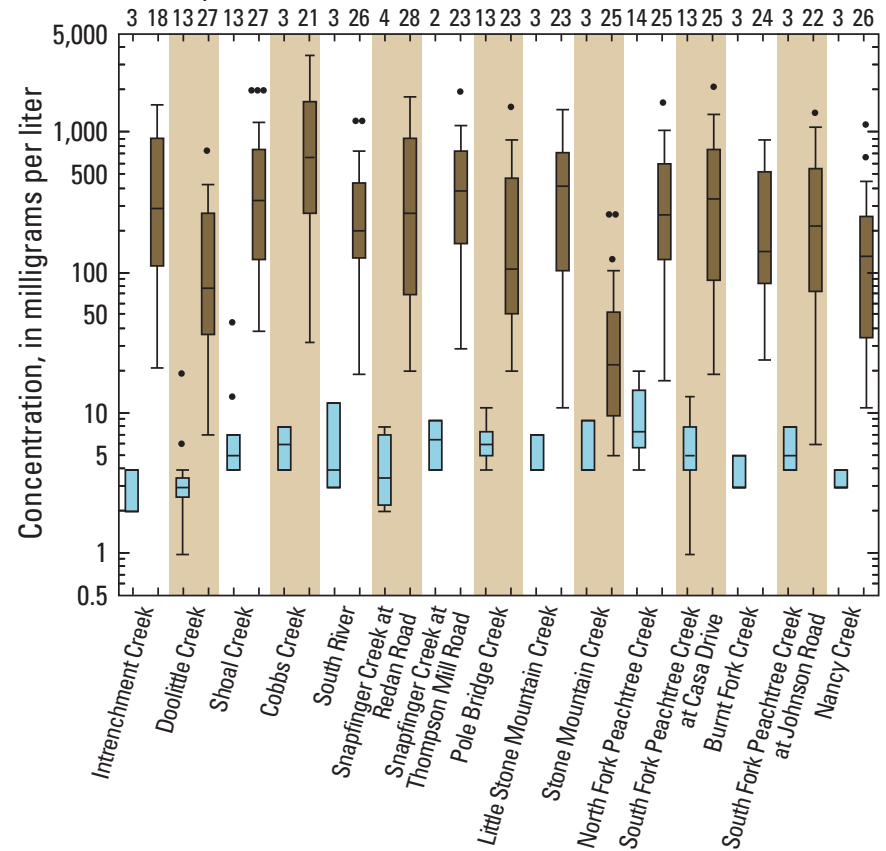

F. Total suspended solids

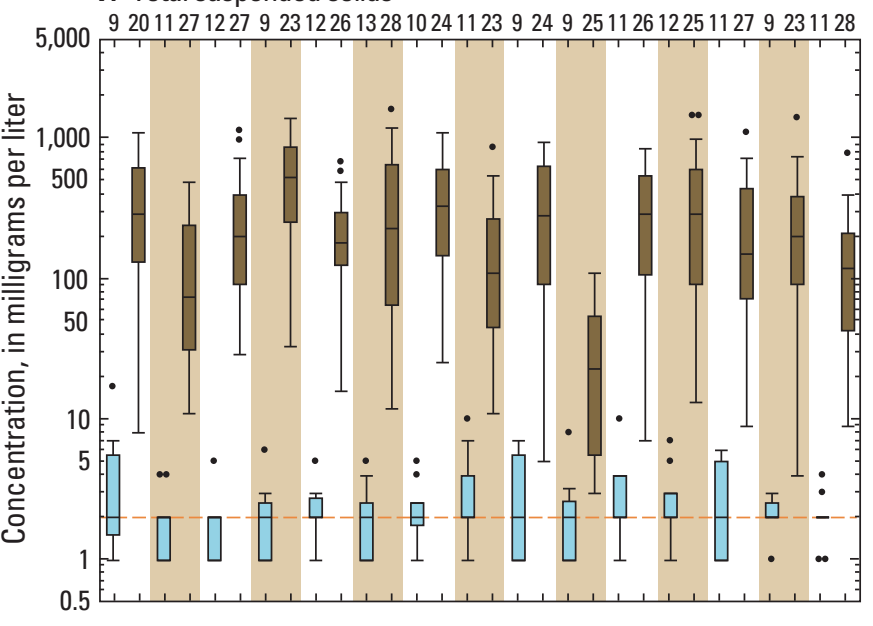

H. Total nitrogen

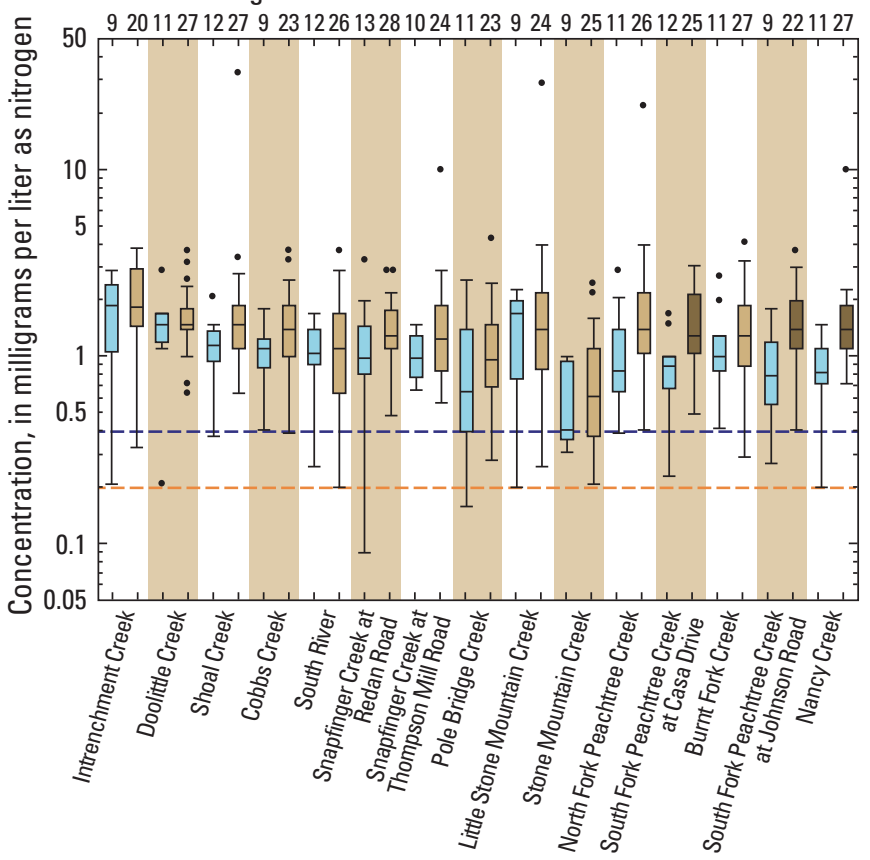

Site

EXPLANATION

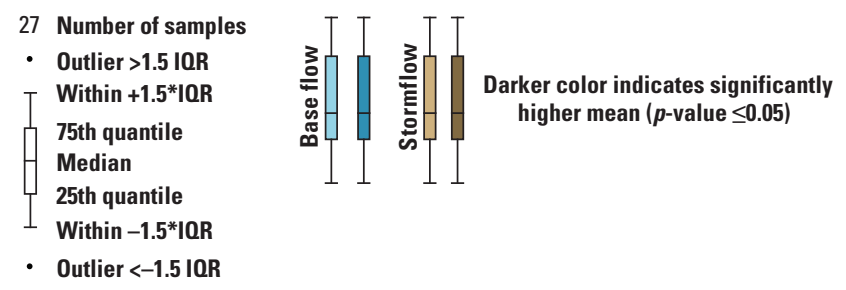
---- Ambient water-quality potential reference condition (U.S. Environmental Protection Agency, 2000a)

--- Predominant laboratory reporting limit

Figure 26. Base-flow and stormflow sample concentration magnitudes at 15 monitored watersheds in DeKalb County, Georgia, 2012-17. A, Sonde specific conductance, $B$, biochemical oxygen demand, $C$, chemical oxygen demand, $D$, sonde $\mathrm{pH}, \mathrm{E}$, laboratory turbidity, $F$, total suspended solids, $G$, suspended-sediment concentration, $H$, total nitrogen, $I$, total nitrate plus nitrite, $J$, total ammonia plus organic nitrogen, $K$, dissolved ammonia, $L$, total phosphorus, $M$, dissolved phosphorus, $N$, total organic carbon, $O$, total calcium, $P$, total magnesium, $Q$, total cadmium, $R$, dissolved cadmium, $S$, total copper, $T$, total lead, $U$, total zinc, and $V$, total dissolved solids. Significant difference between base-flow and stormflow sample concentration distributions determined from Mann-Whitney $\mathrm{U}$ test with a $p$-value of $\leq 0.05$. Abbreviations: IQR, interquartile range; $\mathrm{mg} / \mathrm{L}$, milligrams per liter; $\mathrm{CaCO}_{3}$, calcium carbonate. -Continued 

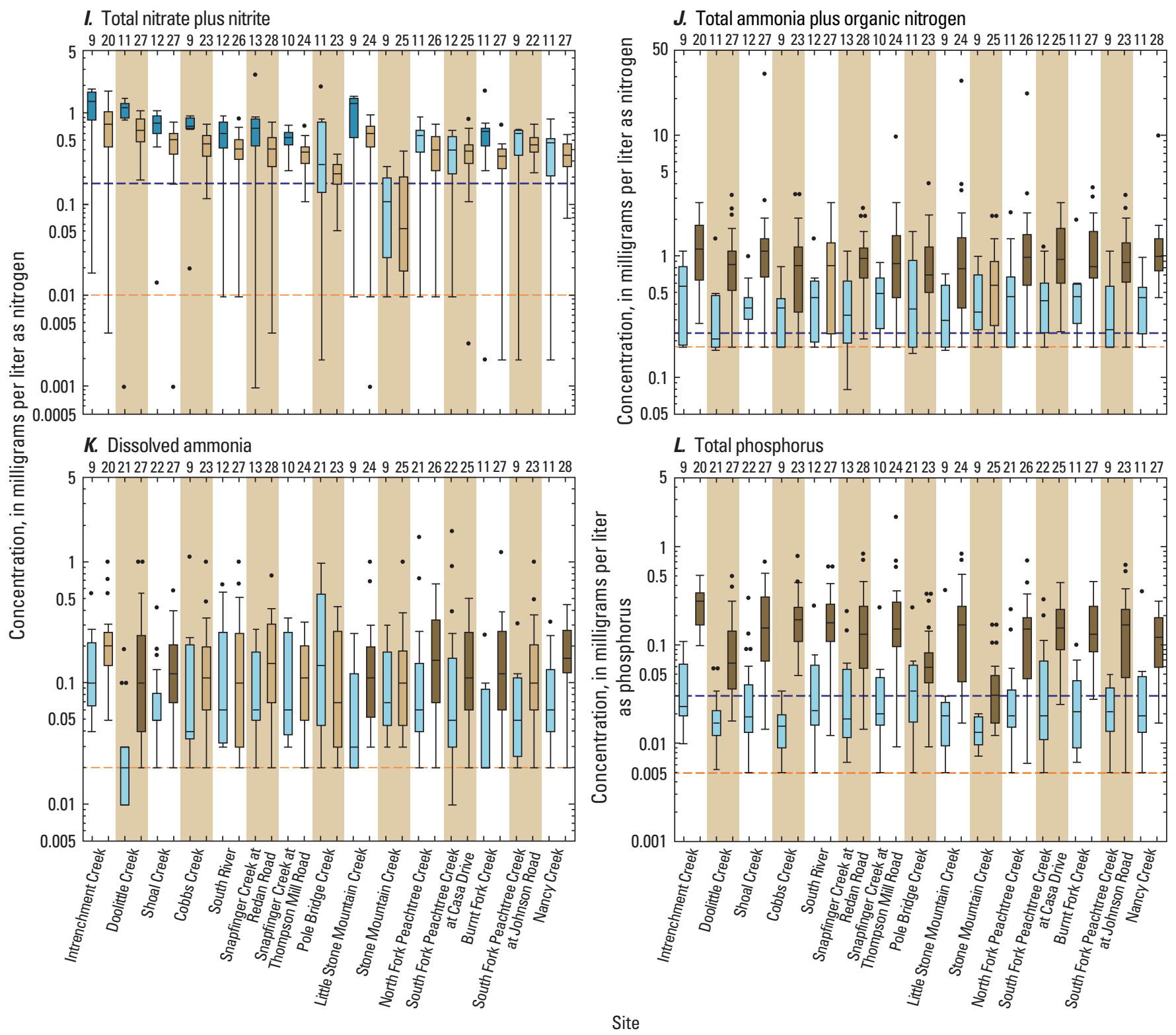

EXPLANATION
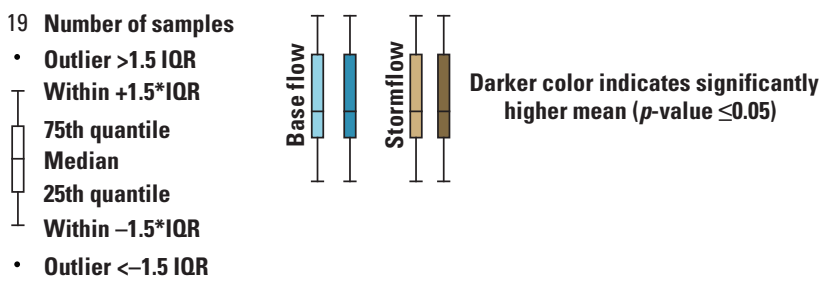

---- Ambient water-quality potential reference condition (U.S. Environmental Protection Agency, 2000a)

---- Predominant laboratory reporting limit

Figure 26. Base-flow and stormflow sample concentration magnitudes at 15 monitored watersheds in DeKalb County, Georgia, 2012-17. $A$, Sonde specific conductance, $B$, biochemical oxygen demand, $C$, chemical oxygen demand, $D$, sonde $\mathrm{pH}, \mathrm{E}$, laboratory turbidity, $F$, total suspended solids, $G$, suspended-sediment concentration, $H$, total nitrogen, $I$, total nitrate plus nitrite, $J$, total ammonia plus organic nitrogen, $K$, dissolved ammonia, $L$, total phosphorus, $M$, dissolved phosphorus, $N$, total organic carbon, $O$, total calcium, $P$, total magnesium, $Q$, total cadmium, $R$, dissolved cadmium, $S$, total copper, $T$, total lead, $U$, total zinc, and $V$, total dissolved solids. Significant difference between base-flow and stormflow sample concentration distributions determined from Mann-Whitney $U$ test with a $p$-value of $\leq 0.05$. Abbreviations: IQR, interquartile range; $\mathrm{mg} / \mathrm{L}$, milligrams per liter; $\mathrm{CaCO}_{3}$, calcium carbonate.-Continued 

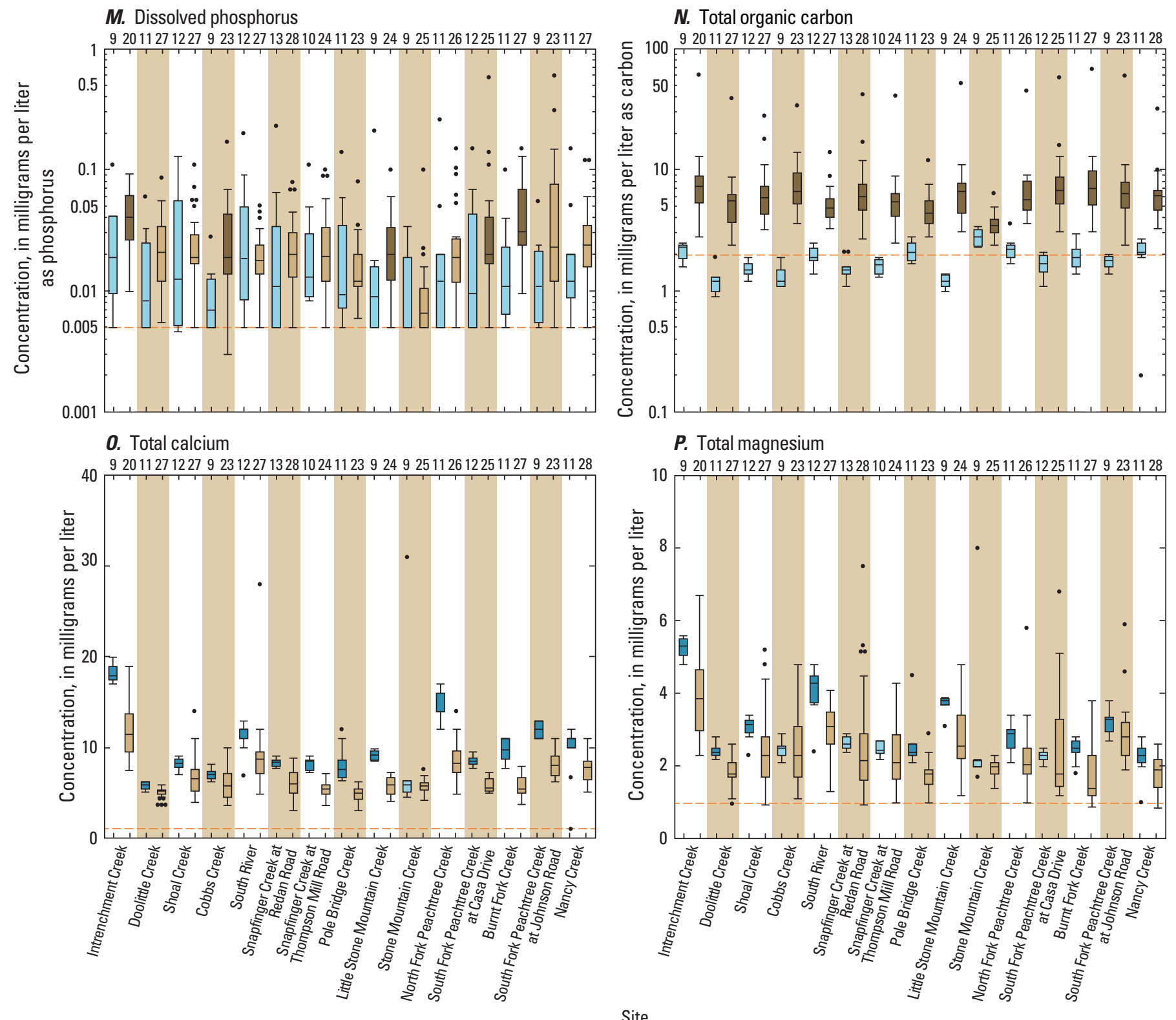

EXPLANATION
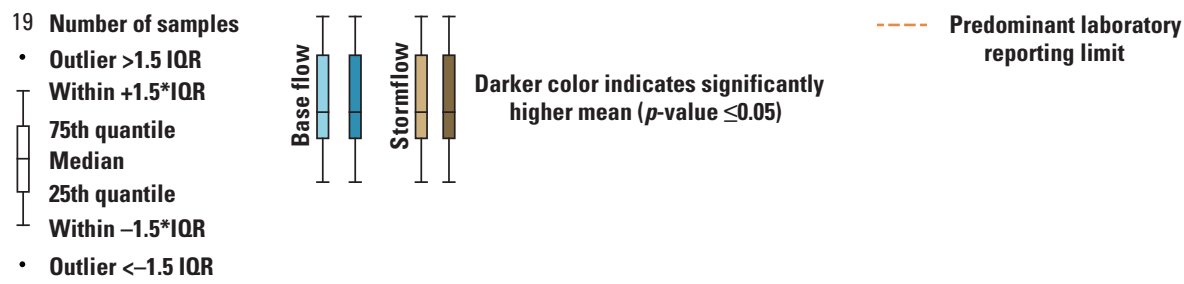

reporting limit

Figure 26. Base-flow and stormflow sample concentration magnitudes at 15 monitored watersheds in DeKalb County, Georgia, 2012-17. A, Sonde specific conductance, $B$, biochemical oxygen demand, $C$, chemical oxygen demand, $D$, sonde $\mathrm{pH}, \mathrm{E}$, laboratory turbidity, $F$, total suspended solids, $G$, suspended-sediment concentration, $H$, total nitrogen, $I$, total nitrate plus nitrite, $J$, total ammonia plus organic nitrogen, $K$, dissolved ammonia, $L$, total phosphorus, $M$, dissolved phosphorus, $N$, total organic carbon, $O$, total calcium, $P$, total magnesium, $Q$, total cadmium, $R$, dissolved cadmium, $S$, total copper, $T$, total lead, $U$, total zinc, and $V$, total dissolved solids. Significant difference between base-flow and stormflow sample concentration distributions determined from Mann-Whitney $\mathrm{U}$ test with a $p$-value of $\leq 0.05$. Abbreviations: IQR, interquartile range; $\mathrm{mg} / \mathrm{L}$, milligrams per liter; $\mathrm{CaCO}_{3}$, calcium carbonate.-Continued 
Q. Total cadmium

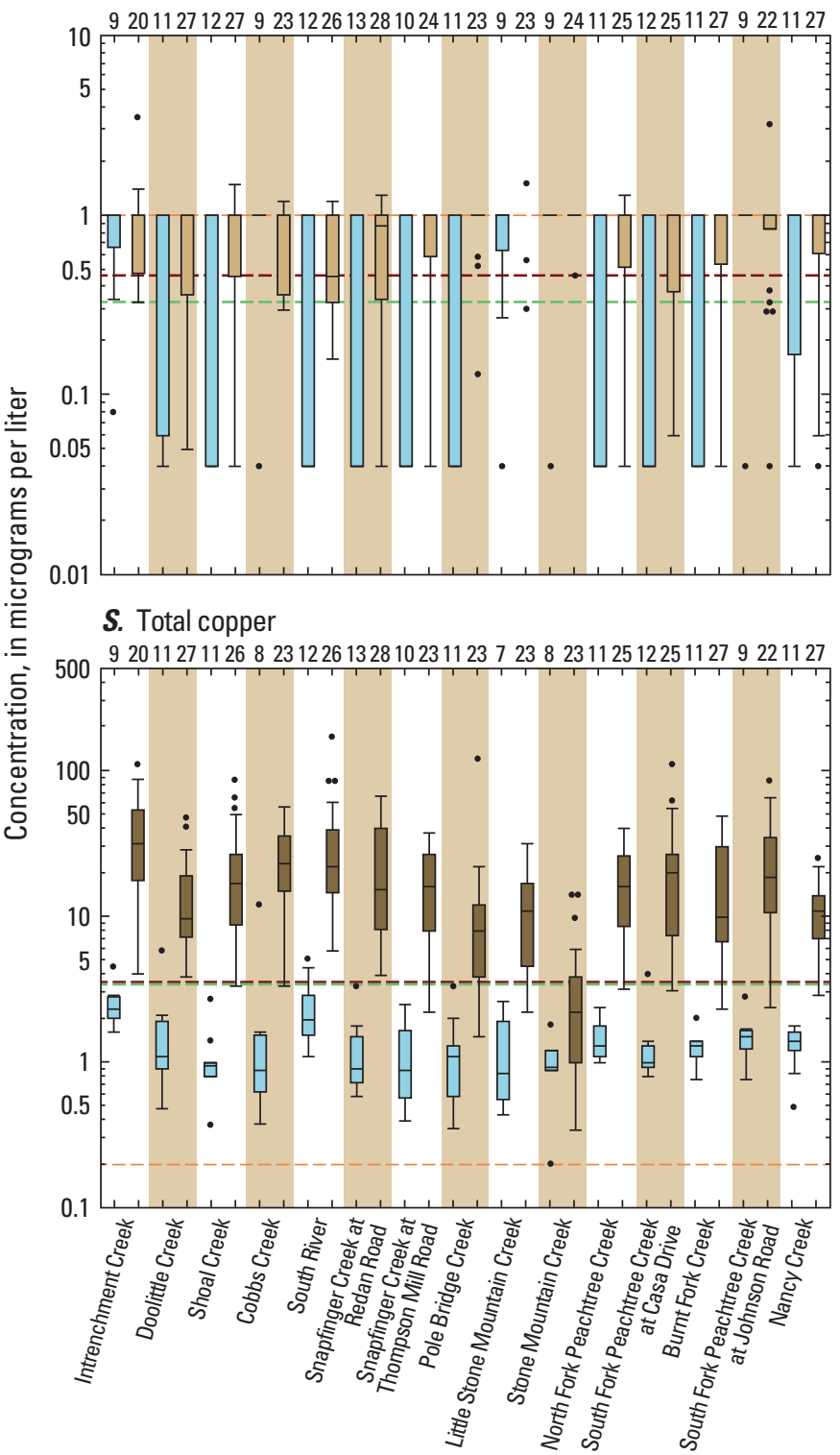

R. Dissolved cadmium

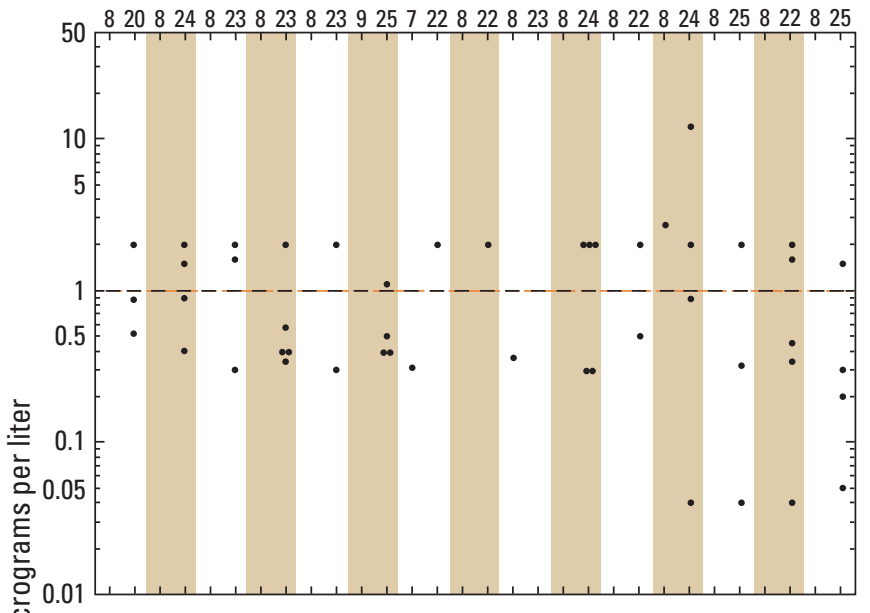

T. Total lead

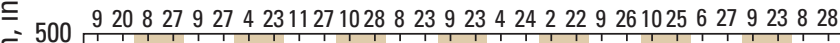

잉

Site

\section{EXPLANATION}

\footnotetext{
19 Number of samples

- Outlier >1.5 IQR

Within +1.5*IOR

75th quantile

Median

25th quantile

$\perp$ Within $-1.5 *$ IOR

- Outlier <-1.5 IQR

- Box plot where all concentrations within the IOR are the same
}

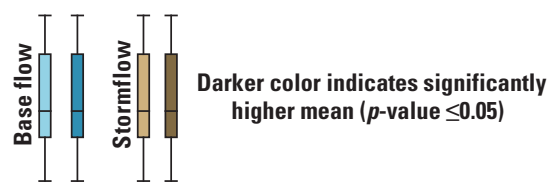
--- National recommended aquatic life criteria maximum concentration (acute 1-hour average; for hardness of $24 \mathrm{mg} / \mathrm{L}$ as $\mathrm{CaCO}_{3}$ ) (U.S. Environmental Protection Agency, 2017)
National recommended aquatic life criteria continuous concentration (chronic; for hardness of $32 \mathrm{mg} / \mathrm{L}$ as $\mathrm{CaCO}_{3}$ ) (U.S. Environmental Protection Agency, 2017)

Figure 26. Base-flow and stormflow sample concentration magnitudes at 15 monitored watersheds in DeKalb County, Georgia, 2012-17. A, Sonde specific conductance, $B$, biochemical oxygen demand, $C$, chemical oxygen demand, $D$, sonde $\mathrm{pH}, \mathrm{E}$, laboratory turbidity, $F$, total suspended solids, $G$, suspended-sediment concentration, $H$, total nitrogen, $I$, total nitrate plus nitrite, $J$, total ammonia plus organic nitrogen, $K$, dissolved ammonia, $L$, total phosphorus, $M$, dissolved phosphorus, $N$, total organic carbon, 0 , total calcium, $P$, total magnesium, $Q$, total cadmium, $R$, dissolved cadmium, $S$, total copper, $T$, total lead, $U$, total zinc, and $V$, total dissolved solids. Significant difference between base-flow and stormflow sample concentration distributions determined from Mann-Whitney $U$ test with a $p$-value of $\leq 0.05$. Abbreviations: IQR, interquartile range; $\mathrm{mg} / \mathrm{L}$, milligrams per liter; $\mathrm{CaCO}_{3}$, calcium carbonate. -Continued 

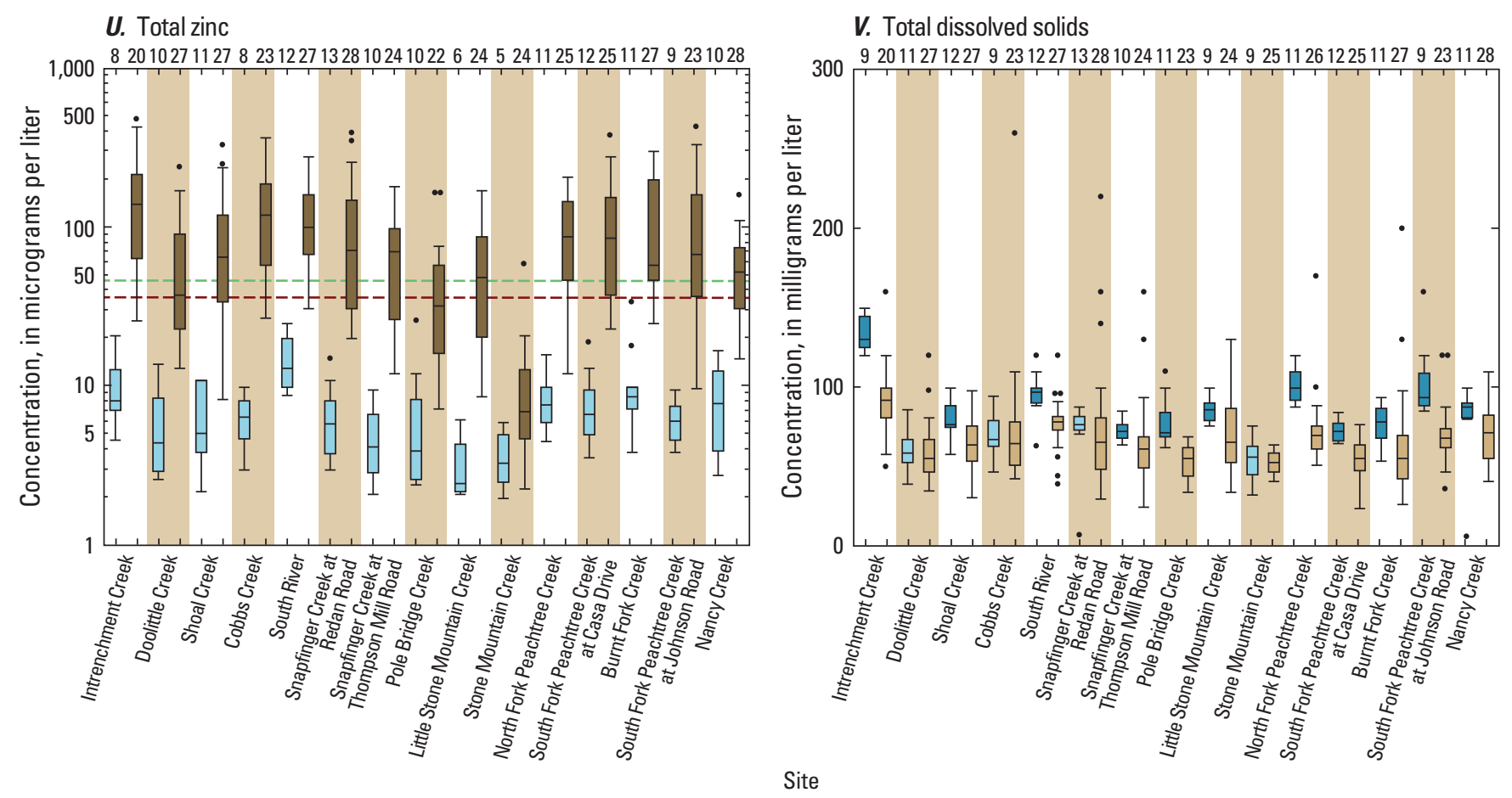

EXPLANATION

$\begin{array}{ll}11 & \text { Number of samples } \\ \text { - } & \text { Outlier }>1.5 \text { IOR } \\ \text { Tithin }+1.5 * \text { IOR } \\ \text { 75th quantile } \\ \text { Median } \\ 25 \text { th quantile } \\ \text { Within }-1.5 * \text { IOR } \\ \text { - Outlier <-1.5 IQR }\end{array}$

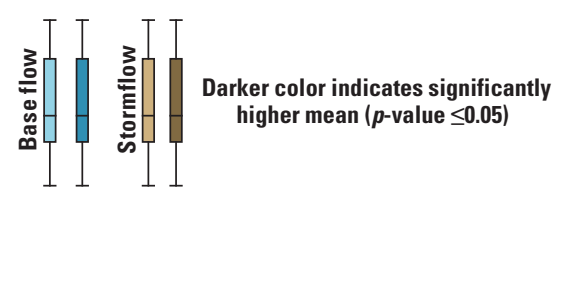
-- - - National recommended aquatic life criteria maximum concentration (acute 1-hour average; for hardness of $24 \mathrm{mg} / \mathrm{L}$ as $\mathrm{CaCO}_{3}$ ) (U.S. Environmental Protection Agency, 2017)
National recommended aquatic life criteria continuous concentration (chronic; for hardness of $32 \mathrm{mg} / \mathrm{L}$ as $\mathrm{CaCO}_{3}$ ) (U.S. Environmental Protection Agency, 2017)

Figure 26. Base-flow and stormflow sample concentration magnitudes at 15 monitored watersheds in DeKalb County, Georgia, 2012-17. A, Sonde specific conductance, $B$, biochemical oxygen demand, $C$, chemical oxygen demand, $D$, sonde $\mathrm{pH}, \mathrm{E}$, laboratory turbidity, $F$, total suspended solids, $G$, suspended-sediment concentration, $H$, total nitrogen, $I$, total nitrate plus nitrite, $J$, total ammonia plus organic nitrogen, $K$, dissolved ammonia, $L$, total phosphorus, $M$, dissolved phosphorus, $N$, total organic carbon, 0 , total calcium, $P$, total magnesium, $Q$, total cadmium, $R$, dissolved cadmium, $S$, total copper, $T$, total lead, $U$, total zinc, and $V$, total dissolved solids. Significant difference between base-flow and stormflow sample concentration distributions determined from Mann-Whitney $U$ test with a $p$-value of $\leq 0.05$. Abbreviations: IQR, interquartile range; $\mathrm{mg} / \mathrm{L}$, milligrams per liter; $\mathrm{CaCO}_{3}$, calcium carbonate.—Continued

Total calcium $(\mathrm{Ca})$ and total magnesium $(\mathrm{Mg})$ concentrations are used to calculate water hardness, which is used in calculating aquatic organisms' toxicity criteria to various dissolved metals in freshwater. Ca concentrations ranged from about 4 to $20 \mathrm{mg} / \mathrm{L}$ (fig. 26O), and Mg concentrations ranged from about 1 to $6 \mathrm{mg} / \mathrm{L}$ (fig. 26P). Concentrations were significantly higher in base-flow samples than in stormflow samples at 14 and 10 of the sites for $\mathrm{Ca}$ and $\mathrm{Mg}$, respectively, indicating the effects of dilution during stormflow conditions. $\mathrm{Ca}$ and $\mathrm{Mg}$ concentrations were highest at the Intrenchment Creek site for base-flow and stormflow samples. Concentrations in baseflow samples were also higher than in stormflow samples for $\mathrm{Ca}$ for the North Fork Peachtree Creek site and for $\mathrm{Mg}$ for the South River and Little Stone Mountain Creek sites.
Heavy metals, such as cadmium, lead, zinc, and copper, can be toxic to aquatic organisms at high enough concentrations. Total cadmium (TCd) concentrations ranged from about 0.04 to $1 \mu \mathrm{g} / \mathrm{L}$ in base-flow and stormflow samples (fig. 26Q). The data are difficult to interpret because the LRL changed during the study. At times the LRL was $<0.04 \mu \mathrm{g} / \mathrm{L}$; however, most of the time it was $<1 \mu \mathrm{g} / \mathrm{L}$, meaning that many concentrations were not measurable. The national recommended aquatic life chronic and acute criteria were below this $<1-\mu \mathrm{g} / \mathrm{L}$ LRL, which makes it difficult to assess exceedance of these criteria. Dissolved cadmium was also typically below the $<1-\mu \mathrm{g} / \mathrm{L}$ LRL (fig. 26R). 
Total copper $(\mathrm{TCu})$, total lead $(\mathrm{TPb})$, and total zinc $(\mathrm{TZn})$ are similar in that their concentrations are much higher in stormflows because increases in their particulate forms are associated with elevated sediment transport during storms. $\mathrm{TCu}$ concentrations ranged from about 0.4 to $3 \mu \mathrm{g} / \mathrm{L}$ in baseflow samples and from 2 to $70 \mu \mathrm{g} / \mathrm{L}$ in stormflow samples, with the exception of Stone Mountain Creek, which had lower concentrations in stormflow samples than the other sites (fig. 26S). $\mathrm{TPb}$ concentrations ranged from about 0.1 to $1 \mu \mathrm{g} / \mathrm{L}$ in base-flow samples and from about 1 to $100 \mu \mathrm{g} / \mathrm{L}$ in stormflow samples (fig. 26T). TZn concentrations ranged from about 2 to $20 \mu \mathrm{g} / \mathrm{L}$ in base-flow samples and from about 10 to $400 \mu \mathrm{g} / \mathrm{L}$ in stormflow samples, with the exception of Stone Mountain Creek, which had lower concentrations in stormflow samples than the other sites, from about 2 to $20 \mu \mathrm{g} / \mathrm{L}$ (fig. 26U). TZn and TCu concentrations were typically higher in stormflow samples than in base-flow samples by about one-and-a-half orders of magnitude, whereas stormflow $\mathrm{TPb}$ concentrations were higher by about one-and-a-half to two orders of magnitude. $\mathrm{TPb}, \mathrm{TZn}$, and $\mathrm{TCu}$ concentrations in stormflow samples were significantly higher than in base-flow samples at all sites except at Stone Mountain Creek for $\mathrm{TPb}$, though significance testing was limited because only two baseflow samples were analyzed for $\mathrm{TPb}$ from this site. Base-flow $\mathrm{TPb}$ concentrations were similar among sites, but base-flow $\mathrm{TZn}$ and $\mathrm{TCu}$ concentrations had substantial differences between sites. During stormflow, the relative magnitudes and variance in concentrations between $\mathrm{TPb}, \mathrm{TZn}$, and $\mathrm{TCu}$ were similar among sites. Stormflow TPb, TZn, and TCu concentrations were highest at the Intrenchment Creek site and lowest at the Stone Mountain Creek site. The lower concentrations in stormflow samples at the Stone Mountain Creek site were associated with lower sediment concentrations during stormflow (figs. $26 F$ and $G$ ), likely because of the large reservoir that limited sediment transport from a substantial portion of the basin.

Concentrations of $\mathrm{TCu}, \mathrm{TPb}$, and $\mathrm{TZn}$ in stormflow and base-flow samples exceeded the national recommended aquatic life criteria for chronic and acute conditions to varying degrees. TCu concentrations in base-flow samples rarely exceeded TCu's chronic criterion $(3.5 \mu \mathrm{g} / \mathrm{L}$ for a hardness of $32 \mathrm{mg} / \mathrm{L}$ as $\mathrm{CaCO}_{3}$ ), and this was only by concentrations designated as high outliers. TCu concentrations in stormflow samples exceeded its acute criterion $(3.6 \mu \mathrm{g} / \mathrm{L}$ for a hardness of $24 \mathrm{mg} / \mathrm{L}$ as $\mathrm{CaCO}_{3}$ ) often, and the median concentrations in stormflow samples were higher than the criterion at all but the Stone Mountain Creek site. TPb concentrations infrequently exceeded the $\mathrm{TPb}$ criteria, with the 75th quantile of concentrations in base-flow samples exceeding the chronic criterion $(0.75 \mu \mathrm{g} / \mathrm{L})$ at four of the sites, and the median of concentrations in stormflow samples exceeded the acute criterion $(13 \mu \mathrm{g} / \mathrm{L})$ at eight of the sites. None of the base-flow TZn concentrations exceeded its chronic criterion $(46 \mu \mathrm{g} / \mathrm{L})$; however, the TZn acute criterion $(36 \mu \mathrm{g} / \mathrm{L})$ was exceeded frequently, with median concentrations in stormwater samples exceeding this criterion at 13 sites.
Total dissolved solids (TDS) concentrations ranged from about 40 to $150 \mathrm{mg} / \mathrm{L}$ in base-flow samples and from about 30 to $120 \mathrm{mg} / \mathrm{L}$ in stormflow samples (fig. $26 \mathrm{~V}$ ). Concentrations were significantly higher in base-flow samples than in stormflow samples from 11 of the sites, indicating the effects of dilution during stormflow conditions. The patterns in TDS were consistent with the patterns observed for SC (fig. 26A). Intrenchment Creek had the highest TDS concentrations for base-flow and stormflow samples, which is consistent with the higher $\mathrm{Ca}$ and $\mathrm{Mg}$ concentrations observed at Intrenchment Creek (figs. 260 and $P$ ). TDS concentrations were also higher in base-flow samples at the South River, North Fork Peachtree Creek, and South Fork Peachtree Creek sites than at other sites. The EPA (2020) has established TDS as a secondary drinking water standard with a maximum contaminant level of $500 \mathrm{mg} / \mathrm{L}$ because high concentrations of TDS can be an indicator of elevated levels of other pollutants. All TDS concentrations were well below this standard.

\section{Bacteria as a Water-Quality Indicator}

Typical E. coli densities ranged from about 10 to 5,000 most probable number per $100 \mathrm{~mL}$ (fig. 27A). Typical fecal coliform densities ranged from about 20 to $10,000 \mathrm{cfu}$ per $100 \mathrm{~mL}$ (fig. 27B). All sites had high outliers for both bacteria types ( $>1.5$ of the interquartile range). The variation in magnitudes of $E$. coli and fecal coliform densities between sites is similar because $E$. coli is a substantial subset of fecal coliform. Bacteria densities were highest at the South River, Snapfinger Creek at Redan Road, Snapfinger Creek at Thompson Mill Road, and North Fork Peachtree Creek sites and lowest at the Little Stone Mountain Creek and Stone Mountain Creek sites. The E. coli densities were frequently above the EPA's recommended BAV of $235 \mathrm{cfu} / 100 \mathrm{~mL}$ (except at the Stone Mountain Creek site), which is an indication of unsafe conditions for primary contact recreation (EPA, 2012). The Georgia bacteria criterion for recreational waters for May through October for fecal coliform (30-day geometric mean of 200 $\mathrm{cfu} / 100 \mathrm{~mL}$ ) was frequently exceeded at most sites because median densities during these months were above this criterion at all sites except for Stone Mountain Creek. The 30-day geometric mean criterion of $1,000 \mathrm{cfu} / 100 \mathrm{~mL}$ during the November through April period was infrequently exceeded by densities of samples collected during these months; at the Snapfinger Creek at Thompson Mill Road site, the median concentration exceeded this criterion, and at the South River and North Fork Peachtree Creek sites, the median densities were near this criterion. The maximum one-time November through April criterion was exceeded by some sample densities during this season at all sites except Little Stone Mountain Creek; exceedances occurred most frequently at the three sites previously identified as having the highest bacteria densities. 


\section{Escherichia coli Modeling}

Predictive regression models for E. coli density were developed for each of the 15 monitoring sites to assess water quality and allow for near real-time estimation. Model statistics and parameters for E. coli are listed in table 12. Model calibration datasets ranged from 30 to 87 samples. Forty outliers representing 3.4 percent of the sample densities were identified and removed from the model calibration datasets. About two-thirds of the outliers were high $(n=26)$. Model residual analysis indicated that the models were well-posed after removing outliers. Whereas the number of samples was sufficient for model calibration, the number of samples with high turbidities and streamflows was insufficient to reliably predict densities when they were high. The lack of representation of these conditions was because storm-composite samples were not analyzed for bacteria because of holding-time concerns of samples collected over a many-hour period. Model predictions of $E$. coli densities are likely to be reasonable for values of up to about 20 percent higher than the highest turbidities and streamflows used to calibrate the models (table 13), which does not require much model extrapolation. Predicted densities are considered unreliable above these levels. Densities of $E$. coli are clearly above the BAV for all models, however, when turbidites and streamflow are this high and are used as sufficient evidence that densities are above the BAV for estimating

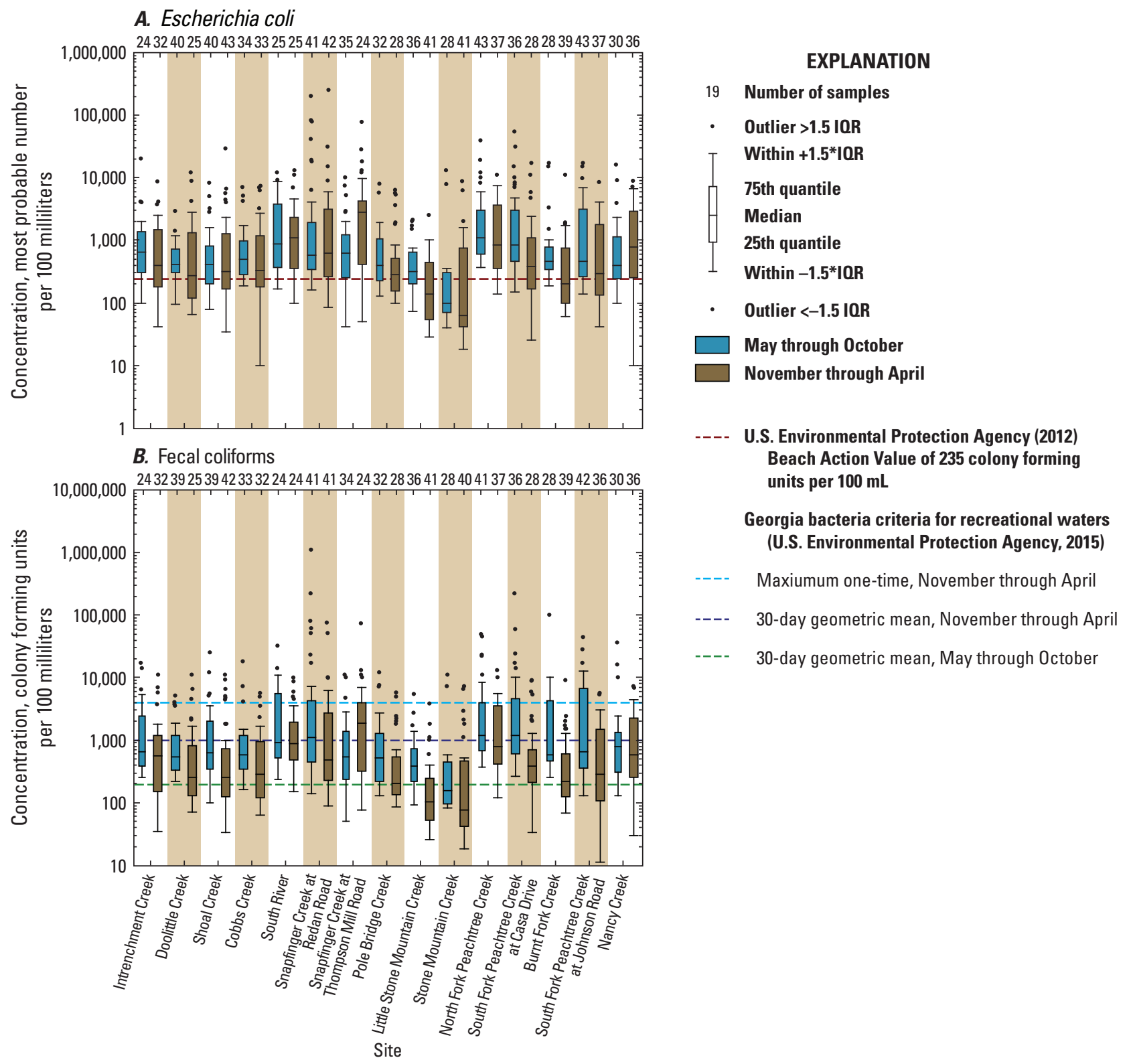

Figure 27. A, Escherichia coli, and B, fecal coliform densities at 15 monitored sites in DeKalb County, Georgia, $2012-17$. Abbreviation: IQR, interquartile range. 
the frequency of BAV exceedance. The root-mean-square error (RMSE) reflects the precision of the model and ranged from 0.256 to 0.603 (table 12). These uncertainties are large, with corresponding \pm 1 standard deviations of -44.5 and +80.2 percent for the lowest RMSE and -75.0 and +301 percent for the highest RMSE. However, a similar E. coli modeling study of three sites on the Chattahoochee River adjacent to the study area with model RMSEs ranging from 0.231 to 0.310 indicated that the models performed well at predicting exceedance of the BAV when predicted densities were infrequently near the BAV (Aulenbach and McKee, 2020). The models that include turbidity had lower RMSEs and higher adjusted $\mathrm{R}^{2} \mathrm{~S}$ than their corresponding nonturbidity models, indicating that the turbidity models have better precision.

The explanatory variables used in the models can provide some insight regarding their relations with variations in $E$. coli densities. Only three of the turbidity models included streamflow explanatory variables, indicating that turbidity explained variations in $E$. coli densities better than streamflow. All the no-turbidity models included streamflow as one of its explanatory variables, indicating that streamflow is a reasonable substitute when turbidity is not available. In 16 models (53 percent), seasonal terms and (or) water temperature data were included as explanatory variables, an indication of seasonal variations in E. coli densities. Generally, models had either seasonal terms or water temperature variables; however, two models included both.

Table 13 summarizes the percentage of time that $E$. coli is predicted to exceed the BAV at each site for the 3 -year period 2014-16. The exceedance of the BAV is consistent with figure $27 A$, which shows $E$. coli densities greater than the BAV in more than half of samples at all sites except Stone Mountain Creek. Four models indicated exceedance of the BAV 100 percent of the time (South River, Snapfinger Creek at Redan Road, Snapfinger Creek at Thompson Mill Road, and Pole Bridge Creek). Modeled exceedances were lowest for Cobbs Creek (44.6 percent) and Stone Mountain Creek (62.5 percent). Bacteria densities may be low at the Stone Mountain Creek site because the reservoir in its watershed may have reduced transport of sediment-associated bacteria. The models predict the average expected $E$. coli densities for the conditions described by the explanatory variables, and the uncertainties in the predictions were not considered when determining the exceedance rate. The preferred model that included the turbidity variables was used in the majority of cases; however, use of turbidity was limited to 52.0 percent of the prediction period for Stone Mountain Creek where the water-quality sonde was not deployed until well into the 3 -year period (table 13).

\section{Constituent Loads and Yields}

The sample concentrations used for estimating loads with the regression-model method and the Beale ratio estimator (BRE) are summarized in the next sections of this report, including details about outliers that were excluded from estimating loads. Summaries of usage of load estimation methods, regression-model statistics, and frequency of model parameter usage are also provided. An example showing the process of evaluating the LOADEST models is presented. Annual load estimates and annual average concentrations for the study watersheds are presented along with yields by watershed for the 2014-16 period. Watershed sediment loads are related to watershed imperviousness.

Datasets and results related to load estimation are provided in a companion data release by Aulenbach and others (2021). The data release includes (1) daily stream base flows determined from hydrograph separation; (2) outlier concentrations removed from load and E. coli estimation datasets including explanations for removal; (3) water-quality data used for LOADEST model calibration and BRE load estimation; (4) LOADEST models including model statistics, model coefficients, and LOADEST model output files used in model assessment; (5) time-step data used for LOADEST load estimation; and (6) annual and study period loads, annual average concentrations, and yields and associated uncertainty estimates.

\section{Calibration Samples and Outliers}

Regression models were fit by using an average of 33.5 samples per model. Model development occurred with a minimum of 20 samples and a maximum of 48 samples. Most constituents had few censored values except for BOD, TSS, TN, and DP, which had greater than 10 percent of their concentrations censored (table 14). The outlier analysis identified 290 concentrations as outliers that were excluded from the calibration datasets (Aulenbach and others, 2021). Outliers represented 3.7 percent of the total sample concentrations. The outliers removed varied by constituent and ranged from 0.6 percent (TSS) to 8.8 percent (DP). BOD had multiple levels of censored values, and even though LOADEST is programmed to function with multiple reporting limits, these levels of censored values complicated load estimation. These issues were resolved by adjusting censored values below $2 \mathrm{mg} / \mathrm{L}$ to the highest censored value of $<2 \mathrm{mg} / \mathrm{L}$ (25 instances).

\section{Load Modeling}

Loads were estimated for 15 constituents at each of the 15 study watersheds, resulting in 225 sets of loads. Of these, 191 were estimated by using LOADEST, and 34 (15.1 percent) were estimated by using the BRE. The BRE was used when constituents had weak concentration relations and occurred most often for the following constituents (the number of watershed models is in parentheses): $\mathrm{TN}(12), \mathrm{NO}_{3}+\mathrm{NO}_{2}(6)$, DP (4), Mg (4), and TDS (5). These constituents had weak concentration relations where LOADEST was used to estimate loads, as indicated by their relatively low ranges of concentration-model-adjusted $\mathrm{R}^{2} \mathrm{~s}$ (table 15 ). 
Table 12. Escherichia coli model statistics and parameter coefficients for 15 monitored sites in DeKalb County, Georgia.

[RMSE, root-mean-square error; $\mathrm{R}^{2}$, coefficient of determination; Log, logarithm base-10; DOY; day-of-year; NoTurb, model without turbidity terms; Turb, model with turbidity term(s); na, not applicable; - , parameter not included in model; Models calibrated for period February 2012 to August 2017]

\begin{tabular}{|c|c|c|c|c|c|c|c|c|c|c|c|c|}
\hline \multirow{3}{*}{ Monitoring site } & \multirow{3}{*}{$\begin{array}{l}\text { Model } \\
\text { type }\end{array}$} & \multirow{3}{*}{$\begin{array}{l}\text { Number } \\
\text { of obser- } \\
\text { vations }\end{array}$} & \multirow{3}{*}{ RMSE } & \multirow{3}{*}{$\begin{array}{l}\text { Model- } \\
\text { adjusted } \\
\mathbf{R}^{2}\end{array}$} & \multirow{3}{*}{$\begin{array}{c}\text { Duan bias } \\
\text { correct- } \\
\text { ion factor } \\
\text { (Duan, } \\
\text { 1983) }\end{array}$} & \multicolumn{7}{|c|}{ Model parameter coefficients } \\
\hline & & & & & & \multirow[b]{2}{*}{ Intercept } & \multirow{2}{*}{$\begin{array}{c}\text { Log, } \\
\text { streamflow }\end{array}$} & \multirow{2}{*}{$\begin{array}{l}\text { Log, } \\
\text { turbidity }\end{array}$} & \multicolumn{2}{|c|}{ Water temperature } & \multicolumn{2}{|c|}{ Seasonal } \\
\hline & & & & & & & & & Value & Squared & Sine DOY & Cosine DOY \\
\hline \multirow[t]{2}{*}{ Intrenchment Creek } & NoTurb & 54 & 0.416 & 0.271 & 1.501 & 2.2923871 & 0.5075112 & na & - & - & - & - \\
\hline & Turb & 47 & 0.406 & 0.343 & 1.487 & 2.071998 & - & 0.6475329 & - & - & - & - \\
\hline \multirow[t]{2}{*}{ Doolittle Creek } & NoTurb & 69 & 0.329 & 0.475 & 1.349 & 1.7885556 & 0.9620815 & na & - & 0.0012882 & - & - \\
\hline & Turb & 69 & 0.334 & 0.504 & 1.350 & 1.9018691 & - & 0.6556496 & 0.021252 & - & - & - \\
\hline \multirow[t]{2}{*}{ Shoal Creek } & NoTurb & 85 & 0.444 & 0.316 & 1.751 & 1.7234215 & 0.881455 & na & - & 0.0007227 & - & - \\
\hline & Turb & 65 & 0.386 & 0.549 & 1.505 & 2.0345787 & - & 0.8560807 & - & - & - & - \\
\hline \multirow[t]{2}{*}{ Cobbs Creek } & NoTurb & 62 & 0.408 & 0.525 & 1.732 & 1.373379 & 1.3446032 & na & - & 0.0010438 & - & - \\
\hline & Turb & 49 & 0.355 & 0.565 & 1.353 & 1.0814089 & 0.9667035 & 0.2419799 & 0.0024691 & - & -0.014533 & 0.4017808 \\
\hline \multirow[t]{2}{*}{ South River } & NoTurb & 87 & 0.352 & 0.549 & 1.420 & 1.266441 & 0.9718099 & na & - & - & - & - \\
\hline & Turb & 76 & 0.334 & 0.584 & 1.384 & 2.2099588 & - & 0.8218273 & - & - & - & - \\
\hline \multirow{2}{*}{$\begin{array}{l}\text { Snapfinger Creek at } \\
\text { Redan Road }\end{array}$} & NoTurb & 86 & 0.474 & 0.345 & 3.678 & 2.1427162 & 0.9010152 & na & - & - & - & - \\
\hline & Turb & 72 & 0.369 & 0.540 & 1.479 & 2.1590786 & - & 0.8933879 & - & - & - & - \\
\hline \multirow{2}{*}{$\begin{array}{l}\text { Snapfinger Creek at } \\
\text { Thompson Mill } \\
\text { Road }\end{array}$} & NoTurb & 80 & 0.548 & 0.266 & 2.236 & 1.8167032 & 0.8006557 & na & - & - & - & - \\
\hline & Turb & 65 & 0.522 & 0.329 & 2.212 & 2.2360424 & - & 0.7326547 & - & - & - & - \\
\hline \multirow[t]{2}{*}{ Pole Bridge Creek } & NoTurb & 71 & 0.370 & 0.236 & 1.448 & 1.7797638 & 0.4545966 & na & 0.0175575 & - & - & - \\
\hline & Turb & 64 & 0.295 & 0.509 & 1.275 & 1.7074237 & - & 0.8870537 & - & - & -0.209954 & -0.088679 \\
\hline \multirow{2}{*}{$\begin{array}{l}\text { Little Stone } \\
\text { Mountain Creek }\end{array}$} & NoTurb & 62 & 0.414 & 0.299 & 1.591 & 2.1716433 & 0.9426245 & na & - & - & -0.100514 & -0.383 \\
\hline & Turb & 45 & 0.313 & 0.437 & 1.339 & 2.0749715 & - & 0.5512765 & - & - & 0.0295018 & -0.150479 \\
\hline \multirow{2}{*}{$\begin{array}{l}\text { Stone Mountain } \\
\text { Creek }\end{array}$} & NoTurb & 62 & 0.603 & 0.106 & 3.991 & 1.4598231 & 0.5008504 & na & - & - & - & - \\
\hline & Turb & 30 & 0.361 & 0.670 & 1.411 & 1.264009 & - & 1.4095134 & - & - & - & - \\
\hline \multirow{2}{*}{$\begin{array}{l}\text { North Fork } \\
\quad \text { Peachtree Creek }\end{array}$} & NoTurb & 87 & 0.406 & 0.265 & 1.575 & 2.4052339 & 0.4888788 & na & - & - & -0.204706 & -0.109407 \\
\hline & Turb & 77 & 0.349 & 0.442 & 1.380 & 2.2247741 & - & 0.682115 & - & 0.0003807 & - & - \\
\hline \multirow{2}{*}{$\begin{array}{l}\text { South Fork } \\
\text { Peachtree Creek } \\
\text { at Casa Drive }\end{array}$} & NoTurb & 85 & 0.395 & 0.372 & 1.654 & 2.4806141 & 0.642658 & na & - & - & -0.096492 & -0.338147 \\
\hline & Turb & 64 & 0.291 & 0.626 & 1.276 & 2.1109542 & - & 0.8051047 & - & - & -0.035214 & -0.16548 \\
\hline \multirow[t]{2}{*}{ Burnt Fork Creek } & NoTurb & 68 & 0.281 & 0.481 & 1.241 & 2.3247453 & 0.5786158 & na & - & - & -0.108394 & -0.339407 \\
\hline & Turb & 63 & 0.256 & 0.588 & 1.169 & 1.8208735 & 0.2839219 & 0.4318835 & 0.0803832 & -0.003324 & -0.114403 & -0.54066 \\
\hline
\end{tabular}


Table 12. Escherichia coli model statistics and parameter coefficients for 15 monitored sites in DeKalb County, Georgia.-Continued

[RMSE, root-mean-square error; $\mathrm{R}^{2}$, coefficient of determination; Log, logarithm base-10; DOY; day-of-year; NoTurb, model without turbidity terms; Turb, model with turbidity term(s); na, not applicable; - , parameter not included in model; Models calibrated for period February 2012 to August 2017]

\begin{tabular}{|c|c|c|c|c|c|c|c|c|c|c|c|c|}
\hline \multirow{3}{*}{ Monitoring site } & \multirow{3}{*}{$\begin{array}{l}\text { Model } \\
\text { type }\end{array}$} & \multirow{3}{*}{$\begin{array}{l}\text { Number } \\
\text { of obser- } \\
\text { vations }\end{array}$} & \multirow{3}{*}{ RMSE } & \multirow{3}{*}{$\begin{array}{l}\text { Model- } \\
\text { adjusted } \\
\mathbf{R}^{2}\end{array}$} & \multirow{3}{*}{$\begin{array}{l}\text { Duan bias } \\
\text { correct- } \\
\text { ion factor } \\
\text { (Duan, } \\
\text { 1983) }\end{array}$} & \multicolumn{7}{|c|}{ Model parameter coefficients } \\
\hline & & & & & & \multirow[b]{2}{*}{ Intercept } & \multirow{2}{*}{$\begin{array}{c}\text { Log, } \\
\text { streamflow }\end{array}$} & \multirow{2}{*}{$\begin{array}{l}\text { Log, } \\
\text { turbidity }\end{array}$} & \multicolumn{2}{|c|}{ Water temperature } & \multicolumn{2}{|c|}{ Seasonal } \\
\hline & & & & & & & & & Value & Squared & Sine DOY & Cosine DOY \\
\hline \multirow{2}{*}{$\begin{array}{l}\text { South Fork } \\
\text { Peachtree Creek } \\
\text { at Johnson Road }\end{array}$} & NoTurb & 62 & 0.442 & 0.514 & 1.863 & 0.9403422 & 1.2217284 & na & - & 0.0009023 & - & - \\
\hline & Turb & 47 & 0.354 & 0.698 & 1.318 & 1.8965775 & - & 1.004185 & - & - & - & - \\
\hline \multirow[t]{2}{*}{ Nancy Creek } & NoTurb & 77 & 0.395 & 0.511 & 1.607 & 1.9376344 & 0.8856648 & na & - & - & - & - \\
\hline & Turb & 61 & 0.302 & 0.640 & 1.278 & 1.8585456 & 0.4728579 & 0.5379804 & - & - & - & - \\
\hline
\end{tabular}


Table 13. Percentage of time Escherichia coli (E. coli) was predicted to be above the Beach Action Value at the 15 monitored sites in DeKalb County for the 3-year period 2014-16. Includes percentage of time when the E. coli model with turbidity explanatory variable(s) were used and percentage of 3-year period represented by model predictions.

$\left[\mathrm{ft}^{3} / \mathrm{s}\right.$, cubic foot per second; FNU, Formazin Nephelometric Units; Beach Action Value is 235 colony forming units per 100 milliliters (U.S. Environmental Protection Agency, 2012)]

\begin{tabular}{lccccc}
\hline \multicolumn{1}{c}{ Monitoring site } & $\begin{array}{c}\text { Maximum } \\
\text { streamflow } \\
\text { in calibration } \\
\text { dataset, } \\
\text { in ft3/s }\end{array}$ & $\begin{array}{c}\text { Maximum } \\
\text { turbidity in } \\
\text { calibration } \\
\text { dataset, } \\
\text { in FNU }\end{array}$ & $\begin{array}{c}\text { Percentage of } \\
\text { time above the } \\
\text { Beach Action } \\
\text { Value }\end{array}$ & $\begin{array}{c}\text { Percentage } \\
\text { of time model } \\
\text { with turbidity } \\
\text { terms used }\end{array}$ & $\begin{array}{c}\text { Percentage } \\
\text { of period with } \\
\text { model } \\
\text { predictions }\end{array}$ \\
\hline Intrenchment Creek & 179 & 210 & 93.3 & 77.5 & 99.2 \\
Doolittle Creek & 57 & 120 & 88.3 & 92.4 & 99.0 \\
Shoal Creek & 158 & 150 & 98.6 & 79.1 & 98.1 \\
Cobbs Creek & 91 & 300 & 44.6 & 80.4 & 99.2 \\
South River & 3,040 & 270 & 100.0 & 88.4 & 99.7 \\
Snapfinger Creek at Redan Road & 188 & 180 & 100.0 & 81.2 & 99.0 \\
Snapfinger Creek at Thompson Mill Road & 920 & 280 & 100.0 & 80.6 & 99.0 \\
Pole Bridge Creek & 434 & 88 & 74.2 & 91.0 & 96.6 \\
\hline Little Stone Mountain Creek & 17 & 110 & 75.4 & 69.5 & 100.0 \\
Stone Mountain Creek & 408 & 27 & 62.5 & 52.0 & 99.9 \\
\hline North Fork Peachtree Creek & 1,320 & 140 & 100.0 & 92.4 & 99.7 \\
South Fork Peachtree Creek at Casa Drive & 66 & 66 & 91.9 & 77.9 & 99.4 \\
Burnt Fork Creek & 47 & 440 & 72.6 & 90.6 & 94.6 \\
South Fork Peachtree Creek at Johnson Road & 487 & 230 & 91.0 & 85.5 & 99.6 \\
Nancy Creek & 318 & 80 & 93.6 & 81.8 & 98.4 \\
\hline
\end{tabular}

For loads estimated with LOADEST, 130 (68.1 percent) used flow-only and flow-turbidity models, and 61 (31.9 percent) used only flow-only models because turbidity was not a significant explanatory variable (table 15). Constituents which infrequently included turbidity as an explanatory variable are predominantly in a dissolved phase and include the following (the number of flow-turbidity models is in parentheses): $\mathrm{COD}(4), \mathrm{NO}_{3}+\mathrm{NO}_{2}$ (2), DP (1), $\mathrm{Ca}(1), \mathrm{Mg}(6)$, and TDS (4). The flow-turbidity models generally had lower residual variances than their corresponding flow-only models, indicating that the inclusion of turbidity improved model predictions. Turbidity data were available 78.7 percent of the time (ranging from 51.9 to 90.1 percent, by watershed), indicating that the preferred flow-turbidity models were predominantly used (table 16). Turbidity data availability was particularly low for Stone Mountain Creek (51.9 percent of the time) because the water-quality sonde was not deployed until almost half-way into the 3-year load estimation period. Periods of missing turbidity data did not occur preferentially during any particular flow condition. The portion of load estimated by using the preferred flow-turbidity models (for constituents that have flow-turbidity models) often differed greatly from the percentage of turbidity data availability, however, depending on the relation between concentration and turbidity.
The residual variance reflects the uncertainty in the load estimates because it represents the amount of unexplained variance that the model could not predict. The residual variances can be compared across constituents despite their different ranges in magnitudes and units because they vary relative to the percentage of their magnitudes as the result of fitting the models in logarithmic space. Residual variances were lowest for $\mathrm{NO}_{3}+\mathrm{NO}_{2}, \mathrm{TOC}, \mathrm{Ca}, \mathrm{Mg}$, and TDS; these are predominantly dissolved-phase constituents (table 15). Residual variances were highest for COD, TSS, TP, and DP.

The flow-only models included an average of 3.6 parameters, whereas the flow-turbidity models included an average of 4.2 parameters. The additional two possible model parameters in the flow-turbidity models often resulted in the replacement of other model parameters selected in the flow-only models, thus indicating that turbidity was a better explanatory variable. Of the nonmandatory model parameters, the frequency of inclusion in the models from most to least were season (43.6 percent), stormflow intercept (38.6 percent), daily base flow ( 31.5 percent), and streamflow base-flow conditions (24.9 percent). In the flow-turbidity models, both turbidity parameters were included in 11.5 percent of the models, only the turbidity parameter for all flow conditions was included in 53.1 percent of the models, and only the turbidity parameter for stormflow conditions was included in 35.4 percent of the 
Table 14. Number of samples used for calibrating load regression models by constituent for 15 monitored watersheds in DeKalb County, Georgia. Includes number and percentage of outliers removed and censored samples.

\begin{tabular}{lcccccc}
\hline \multicolumn{1}{c}{ Constituent } & $\begin{array}{c}\text { Number of } \\
\text { samples } \\
\text { in initial } \\
\text { dataset }\end{array}$ & $\begin{array}{c}\text { Number } \\
\text { of } \\
\text { outliers }\end{array}$ & $\begin{array}{c}\text { Percentage } \\
\text { of outliers }\end{array}$ & $\begin{array}{c}\text { Number of } \\
\text { samples in } \\
\text { calibration } \\
\text { datasets }\end{array}$ & $\begin{array}{c}\text { Number of } \\
\text { censored } \\
\text { samples } \\
\text { calibration } \\
\text { datasets }\end{array}$ & $\begin{array}{c}\text { Percentage } \\
\text { of censored } \\
\text { samples in } \\
\text { calibration } \\
\text { datasets }\end{array}$ \\
\hline Biochemical oxygen demand & 518 & 15 & 2.9 & 503 & 92 & 18.3 \\
Chemical oxygen demand & 506 & 39 & 7.7 & 467 & 7 & 1.5 \\
Total suspended solids & 535 & 3 & 0.6 & 532 & 86 & 16.2 \\
Suspended-sediment concentration & 459 & 11 & 2.4 & 448 & 0 & 0.0 \\
Total nitrogen & 533 & 19 & 3.6 & 514 & 81 & 15.8 \\
Total nitrate plus nitrite & 533 & 28 & 5.3 & 505 & 11 & 2.2 \\
Total phosphorus & 585 & 29 & 5.0 & 556 & 10 & 1.8 \\
Dissolved phosphorus & 535 & 47 & 8.8 & 488 & 54 & 11.1 \\
Total organic carbon & 536 & 19 & 3.5 & 517 & 1 & 0.2 \\
Total calcium & 536 & 14 & 2.6 & 522 & 0 & 0.0 \\
Total magnesium & 536 & 12 & 2.2 & 524 & 0 & 0.0 \\
Total copper & 522 & 10 & 1.9 & 512 & 1 & 0.2 \\
Total lead & 489 & 13 & 2.7 & 476 & 1 & 0.2 \\
Total zinc & 520 & 9 & 1.7 & 511 & 0 & 0.0 \\
Total dissolved solids & 536 & 22 & 4.1 & 514 & 0 & 0.0 \\
\hline Total & 7,879 & 290 & 3.7 & 7,589 & 344 & 4.5 \\
\hline
\end{tabular}

models. The inclusion of each model parameter in a moderate percentage of the models indicates its utility in explaining the variations in constituent concentrations.

The occurrence of stormflow conditions, as defined by turbidity $>20 \mathrm{FNU}$, varied by watershed and ranged from 4.1 to 25.9 percent of the time (table 16). Stormflow occurred infrequently at Stone Mountain Creek (4.1 percent of the time) because the large reservoir moderated stormflows and reduced particulate transport, as evident in the turbidity values for stormflow samples (fig. 26E). Stormflow occurrence was highest at Intrenchment Creek (25.9 percent of the time), partly because the return of treated CSO to the stream in the later part of storm hydrographs extended stormflow conditions. Watershed drainage area was moderately correlated to the percentage of time as stormflow $(r=0.511)$; when excluding Intrenchment Creek and Stone Mountain Creek, the correlation was strong $(r=0.874)$. Larger watersheds likely have longer periods of stormflow because it takes longer for water to reach the watershed outlet and the attenuation of the storm hydrograph.

Load estimation computational time steps ranged from 3 to 12 hours (table 16). Time-step length and watershed drainage area were moderately correlated $(r=0.522)$, indicating that drainage area is just one factor in the time-step length. Time-step length and stormflow occurrence were not significantly correlated $(r=-0.007)$; however, a moderate correlation $(r=0.689)$ was evident if Intrenchment Creek and Stone Mountain Creek, which have atypical stormflow percentages, were excluded.

The percentage of time that daily average streamflow was substituted into time steps with missing unit-value streamflows varied by watershed and ranged from 0.04 to 5.97 percent (table 16). Loads estimated on days with substitutions when streamflows varied greatly could be biased, particularly for constituents in which concentrations vary greatly with streamflow. Time-step average streamflows rarely exceeded the range of flows included in the calibration dataset, with exceedances occurring between 0.03 to 0.68 percent of the time by watershed (table 16), indicating that load models were infrequently extrapolated.

A description and example of how LOADEST load models were evaluated is provided in appendix 3 .

\section{Annual Loads for Study Watersheds}

The annual loads (table 17; figs. 28A-H) and average annual concentrations (figs. $29 A-H$ ) were calculated for 15 constituents for the entire study area for 2014-16. Annual loads generally varied with annual runoff, but climate was also influential. Annual runoff was highest in 2015 and was low in 2014 and 2016 (fig. 13; table 17), and precipitation was average in 2014, above average in 2015, and below average in 2016 (fig. 11; table 17; precipitation average based on 
$\left[\mathrm{R}^{2}\right.$, coefficient of determination; BOD, biochemical oxygen demand; Q, flow-only model; QT, flow-turbidity model; na, not applicable; COD, chemical oxygen demand; TSS, total suspended solids; SSC, suspended-sediment concentration; TN, total nitrogen; $\mathrm{NO}_{3}+\mathrm{NO}_{2}$, total nitrate plus nitrite; TP, total phosphorus; DP, dissolved phosphorus; TOC, total organic carbon; Ca, total calcium; Mg, total magnesium; $\mathrm{TCu}$, total copper; $\mathrm{TPb}$, total lead; TZn, total zinc; TDS, total dissolved solids; number of model parameters includes mandatory model intercept and streamflow parameters, and seasonal terms count as one parameter]

\begin{tabular}{|c|c|c|c|c|c|c|c|c|c|c|c|c|}
\hline \multirow[b]{2}{*}{$\begin{array}{l}\text { Constit- } \\
\text { uent }\end{array}$} & \multirow[b]{2}{*}{$\begin{array}{c}\text { Model } \\
\text { type }\end{array}$} & \multirow[b]{2}{*}{$\begin{array}{l}\text { Number of } \\
\text { models }\end{array}$} & \multirow[b]{2}{*}{$\begin{array}{l}\text { Average } \\
\text { of residual } \\
\text { variance }\end{array}$} & \multirow[b]{2}{*}{$\begin{array}{c}\text { Range of } \\
\text { concentration, } \\
\text { model-adjusted } \text { R }^{2}\end{array}$} & \multirow[b]{2}{*}{$\begin{array}{l}\text { Range of } \\
\text { LOADEST } \\
\text { model } R^{2}\end{array}$} & \multirow[b]{2}{*}{$\begin{array}{c}\text { Average } \\
\text { number } \\
\text { of model } \\
\text { parameters }\end{array}$} & \multicolumn{6}{|c|}{ Percentage of models that include parameter } \\
\hline & & & & & & & $\begin{array}{c}\text { Stormflow } \\
\text { intercept }\end{array}$ & $\begin{array}{c}\text { Streamflow } \\
\text { and base- } \\
\text { flow } \\
\text { conditions }\end{array}$ & $\begin{array}{l}\text { Daily } \\
\text { base } \\
\text { flow }\end{array}$ & Turbidity & $\begin{array}{l}\text { Turbidity, } \\
\text { stormflow } \\
\text { conditions }\end{array}$ & Season \\
\hline \multirow[t]{2}{*}{ BOD } & Q & 15 & 0.269 & $0.289-0.863$ & $0.906-0.984$ & 3.0 & 33 & 20 & 27 & na & na & 20 \\
\hline & QT & 12 & 0.235 & $0.324-0.764$ & $0.921-0.981$ & 3.7 & 17 & 17 & 8 & 67 & 42 & 17 \\
\hline \multirow[t]{2}{*}{ COD } & Q & 13 & 0.326 & $0.166-0.657$ & $0.867-0.969$ & 3.3 & 62 & 38 & 8 & na & na & 23 \\
\hline & QT & 4 & 0.343 & $0.296-0.407$ & $0.897-0.970$ & 3.3 & 0 & 0 & 0 & 75 & 50 & 0 \\
\hline \multirow[t]{2}{*}{ TSS } & Q & 15 & 0.452 & $0.808-0.952$ & $0.938-0.984$ & 3.9 & 53 & 27 & 27 & na & na & 80 \\
\hline & QT & 15 & 0.257 & $0.880-0.975$ & $0.970-0.994$ & 3.9 & 13 & 13 & 13 & 73 & 33 & 40 \\
\hline \multirow[t]{2}{*}{$\mathrm{SSC}$} & Q & 15 & 0.275 & $0.841-0.949$ & $0.954-0.984$ & 3.9 & 40 & 27 & 60 & na & na & 67 \\
\hline & QT & 15 & 0.127 & $0.925-0.984$ & $0.980-0.995$ & 4.2 & 40 & 0 & 20 & 100 & 7 & 53 \\
\hline \multirow[t]{2}{*}{$\mathrm{TN}$} & Q & 3 & 0.283 & $0.237-0.285$ & $0.866-0.958$ & 2.7 & 33 & 33 & 0 & na & na & 0 \\
\hline & QT & 2 & 0.238 & $0.283-0.432$ & $0.874-0.967$ & 4.0 & 0 & 50 & 0 & 100 & 50 & 0 \\
\hline \multirow[t]{2}{*}{$\mathrm{NO}_{3}+\mathrm{NO}_{2}$} & $\mathrm{Q}$ & 9 & 0.099 & $0.314-0.655$ & $0.932-0.976$ & 3.9 & 33 & 33 & 56 & na & na & 67 \\
\hline & QT & 2 & 0.116 & $0.371-0.630$ & $0.940-0.947$ & 5.5 & 50 & 50 & 100 & 50 & 50 & 50 \\
\hline \multirow[t]{2}{*}{$\mathrm{TP}$} & Q & 15 & 0.529 & $0.106-0.788$ & $0.871-0.994$ & 3.4 & 27 & 33 & 47 & na & na & 33 \\
\hline & QT & 10 & 0.587 & $0.381-0.787$ & $0.874-0.980$ & 3.9 & 0 & 10 & 40 & 80 & 30 & 30 \\
\hline \multirow[t]{2}{*}{ DP } & $\mathrm{Q}$ & 11 & 0.395 & $0.242-0.524$ & $0.817-0.955$ & 3.0 & 27 & 36 & 0 & na & na & 36 \\
\hline & QT & 1 & 0.210 & $0.581-0.581$ & $0.960-0.960$ & 5.0 & 0 & 100 & 0 & 100 & 100 & 0 \\
\hline \multirow[t]{2}{*}{ TOC } & $\mathrm{Q}$ & 15 & 0.049 & $0.684-0.948$ & $0.986-0.995$ & 4.7 & 80 & 47 & 80 & na & na & 67 \\
\hline & QT & 15 & 0.045 & $0.698-0.955$ & $0.984-0.996$ & 4.9 & 47 & 33 & 73 & 20 & 80 & 40 \\
\hline \multirow[t]{2}{*}{$\mathrm{Ca}$} & $\mathrm{Q}$ & 14 & 0.026 & $0.275-0.834$ & $0.975-0.997$ & 3.2 & 43 & 21 & 14 & na & na & 43 \\
\hline & QT & 1 & 0.012 & $0.842-0.842$ & $0.994-0.994$ & 4.0 & 100 & 0 & 0 & 0 & 100 & 0 \\
\hline \multirow[t]{2}{*}{$\mathrm{Mg}$} & Q & 11 & 0.059 & $0.166-0.682$ & $0.956-0.994$ & 3.5 & 73 & 18 & 9 & na & na & 45 \\
\hline & QT & 6 & 0.060 & $0.261-0.760$ & $0.965-0.994$ & 4.5 & 83 & 17 & 17 & 17 & 83 & 33 \\
\hline \multirow[t]{2}{*}{$\mathrm{TCu}$} & $\mathrm{Q}$ & 15 & 0.233 & $0.303-0.934$ & $0.913-0.990$ & 3.9 & 40 & 33 & 47 & na & na & 67 \\
\hline & QT & 14 & 0.177 & $0.801-0.954$ & $0.957-0.993$ & 4.3 & 29 & 21 & 29 & 64 & 43 & 43 \\
\hline \multirow[t]{2}{*}{$\mathrm{TPb}$} & Q & 15 & 0.294 & $0.492-0.936$ & $0.876-0.984$ & 3.8 & 33 & 40 & 40 & na & na & 67 \\
\hline & QT & 15 & 0.176 & $0.548-0.983$ & $0.895-0.996$ & 4.3 & 27 & 27 & 27 & 67 & 47 & 40 \\
\hline
\end{tabular}


Table 15. Summary of LOADEST model statistics and parameter by constituent and model type for 15 monitored watersheds in DeKalb County, Georgia.-Continued

$\left[\mathrm{R}^{2}\right.$, coefficient of determination; BOD, biochemical oxygen demand; Q, flow-only model; QT, flow-turbidity model; na, not applicable; COD, chemical oxygen demand; TSS, total suspended solids; SSC, suspended-sediment concentration; TN, total nitrogen; $\mathrm{NO}_{3}+\mathrm{NO}_{2}$, total nitrate plus nitrite; TP, total phosphorus; DP, dissolved phosphorus; TOC, total organic carbon; Ca, total calcium; Mg, total magnesium; $\mathrm{TCu}$, total copper; $\mathrm{TPb}$, total lead; TZn, total zinc; TDS, total dissolved solids; number of model parameters includes mandatory model intercept and streamflow parameters, and seasonal terms count as one parameter]

\begin{tabular}{|c|c|c|c|c|c|c|c|c|c|c|c|c|}
\hline \multirow[b]{2}{*}{$\begin{array}{c}\text { Constit- } \\
\text { uent }\end{array}$} & \multirow[b]{2}{*}{$\begin{array}{l}\text { Model } \\
\text { type }\end{array}$} & \multirow[b]{2}{*}{$\begin{array}{c}\text { Number of } \\
\text { models }\end{array}$} & \multirow[b]{2}{*}{$\begin{array}{l}\text { Average } \\
\text { of residual } \\
\text { variance }\end{array}$} & \multirow[b]{2}{*}{$\begin{array}{c}\text { Range of } \\
\text { concentration, } \\
\text { model-adjusted R² }\end{array}$} & \multirow[b]{2}{*}{$\begin{array}{l}\text { Range of } \\
\text { LOADEST } \\
\text { model } R^{2}\end{array}$} & \multirow[b]{2}{*}{$\begin{array}{c}\text { Average } \\
\text { number } \\
\text { of model } \\
\text { parameters }\end{array}$} & \multicolumn{6}{|c|}{ Percentage of models that include parameter } \\
\hline & & & & & & & $\begin{array}{c}\text { Stormflow } \\
\text { intercept }\end{array}$ & $\begin{array}{l}\text { Streamflow } \\
\text { and base- } \\
\text { flow } \\
\text { conditions }\end{array}$ & $\begin{array}{l}\text { Daily } \\
\text { base } \\
\text { flow }\end{array}$ & Turbidity & $\begin{array}{l}\text { Turbidity, } \\
\text { stormflow } \\
\text { conditions }\end{array}$ & Season \\
\hline \multirow[t]{2}{*}{$\mathrm{TZn}$} & Q & 15 & 0.233 & $0.372-0.912$ & $0.906-0.987$ & 3.7 & 40 & 20 & 47 & na & na & 67 \\
\hline & QT & 14 & 0.156 & $0.790-0.955$ & $0.951-0.995$ & 4.5 & 29 & 29 & 29 & 86 & 50 & 29 \\
\hline \multirow[t]{2}{*}{ TDS } & Q & 10 & 0.038 & $0.188-0.693$ & $0.974-0.995$ & 2.6 & 50 & 0 & 0 & na & na & 10 \\
\hline & QT & 4 & 0.033 & $0.331-0.659$ & $0.979-0.994$ & 3.8 & 50 & 0 & 0 & 0 & 100 & 25 \\
\hline \multirow[t]{3}{*}{ Total } & Q & 191 & 0.245 & $0.106-0.952$ & $0.817-0.997$ & 3.6 & 45.0 & 28.8 & 34.0 & na & na & 49.7 \\
\hline & QT & 130 & 0.194 & $0.261-0.984$ & $0.874-0.996$ & 4.2 & 29.2 & 19.2 & 27.7 & 64.6 & 46.9 & 34.6 \\
\hline & Q \& QT & 321 & 0.224 & $0.106-0.984$ & $0.817-0.997$ & 3.8 & 38.6 & 24.9 & 31.5 & 26.2 & 19.0 & 43.6 \\
\hline
\end{tabular}


Table 16. Summary of load estimation computational time steps, the frequency of turbidity data availability including the portion of runoff and load representation, the occurrence of stormflow conditions, the frequency of daily streamflow substitutions, and the frequency of streamflow exceedance of their calibration dataset maximum streamflow at the 15 monitored watersheds in DeKalb County for their respective 3- to 5-year periods of load estimates.

[na, not applicable; $\mathrm{S}$, indicator variable where $\mathrm{S}=1$ is stormflow conditions]

\begin{tabular}{|c|c|c|c|c|c|c|c|}
\hline Watershed & $\begin{array}{l}\text { Frequency of } \\
\text { availability } \\
\text { of turbidity } \\
\text { data, } \\
\text { in percent }\end{array}$ & $\begin{array}{l}\text { Percentage } \\
\text { of runoff } \\
\text { with } \\
\text { turbidity } \\
\text { available, } \\
\text { in percent }\end{array}$ & $\begin{array}{c}\text { Range of } \\
\text { percentages of } \\
\text { load estimated } \\
\text { using flow- } \\
\text { turbidity model }\end{array}$ & $\begin{array}{l}\text { Percentage of } \\
\text { time in stormflow } \\
\text { conditions } \\
(S=1)\end{array}$ & $\begin{array}{c}\text { Load } \\
\text { estimation } \\
\text { time step, } \\
\text { in hours }\end{array}$ & $\begin{array}{l}\text { Percentage of time when } \\
\text { daily average streamflow } \\
\text { was substituted into time } \\
\text { steps with missing unit- } \\
\text { value streamflow }\end{array}$ & $\begin{array}{l}\text { Percentage of time } \\
\text { when time-step } \\
\text { averaged streamflows } \\
\text { exceeded the range of } \\
\text { flows included in the } \\
\text { calibration dataset }\end{array}$ \\
\hline Intrenchment Creek & 76.4 & 62.0 & $31.6-60.8$ & 25.9 & 3 & 3.66 & 0.11 \\
\hline Doolittle Creek & 83.9 & 78.7 & $72.3-82.0$ & 9.8 & 4 & 1.88 & 0.09 \\
\hline Shoal Creek & 74.5 & 64.4 & $45.1-73.5$ & 14.8 & 6 & 1.02 & 0.07 \\
\hline Cobbs Creek & 79.4 & 67.4 & $27.6-75.4$ & 13.6 & 3 & 0.06 & 0.29 \\
\hline South River & 90.1 & 89.5 & $88.1-90.8$ & 23.8 & 8 & 0.76 & 0.21 \\
\hline Snapfinger Creek at Redan Road & 76.0 & 67.2 & $44.5-61.5$ & 12.3 & 4 & 5.75 & 0.21 \\
\hline $\begin{array}{l}\text { Snapfinger Creek at Thompson Mill } \\
\text { Road }\end{array}$ & 80.4 & 69.2 & $60.6-100.0$ & 20.2 & 8 & 1.10 & 0.07 \\
\hline Pole Bridge Creek & 88.3 & 88.1 & $73.6-89.6$ & 11.2 & 6 & 0.14 & 0.68 \\
\hline Little Stone Mountain Creek & 69.2 & 73.3 & $71.4-79.7$ & 8.9 & 4 & 0.04 & 0.12 \\
\hline Stone Mountain Creek & 51.9 & 52.6 & $48.5-66.5$ & 4.1 & 12 & 0.18 & 0.14 \\
\hline North Fork Peachtree Creek & 88.8 & 94.1 & $93.6-98.0$ & 18.4 & 12 & 0.77 & 0.03 \\
\hline $\begin{array}{l}\text { South Fork Peachtree Creek at Casa } \\
\text { Drive }\end{array}$ & 69.4 & 69.1 & $53.6-69.9$ & 12.1 & 4 & 2.09 & 0.22 \\
\hline Burnt Fork Creek & 87.0 & 76.6 & $52.6-78.3$ & 10.2 & 4 & 5.97 & 0.17 \\
\hline $\begin{array}{l}\text { South Fork Peachtree Creek at } \\
\text { Johnson Road }\end{array}$ & 85.2 & 84.6 & $80.6-91.8$ & 16.0 & 8 & 0.18 & 0.49 \\
\hline Nancy Creek & 79.5 & 75.0 & $57.6-74.4$ & 12.8 & 8 & 2.26 & 0.23 \\
\hline Minimum & 51.9 & 52.6 & $27.6-60.8$ & 4.1 & 3 & 0.04 & 0.03 \\
\hline Maximum & 90.1 & 94.1 & $93.6-100.0$ & 25.9 & 12 & 5.97 & 0.68 \\
\hline All watersheds & 78.7 & 74.1 & na & 14.3 & na & 1.85 & 0.20 \\
\hline
\end{tabular}


the 30-year average during 1981-2010 for Atlanta DeKalb Peachtree Airport station USW00053863, National Oceanic and Atmospheric Administration, 2018).

Confidence intervals for load estimates are provided for all annual loads (figs. 28 and 29). Particulate constituents (TSS, SSC, TN, TP, TCu, TPb, and TZn) and COD had substantially higher uncertainty than constituents that are predominantly dissolved $\left(\mathrm{NO}_{3}+\mathrm{NO}_{2}, \mathrm{DP}, \mathrm{Ca}, \mathrm{Mg}\right.$, and TDS $)$ and that exhibited less variability (fig. 26), while BOD and TOC loads had an intermediate amount of uncertainty. The ability to discern significant differences in load estimates between years is dependent upon the amount of uncertainty in estimating the loads and average concentrations.

BOD and COD loads were similar in 2014 and 2016 when runoff was lower and were significantly lower than in 2015 when runoff was higher (fig. 28A). Suspended-sediment loads averaged 394,000 pounds per year (lb/yr) as TSS and $595,000 \mathrm{lb} / \mathrm{yr}$ as SSC during 2014-16 (fig. 28B). SSC loads were 51.2 percent higher than TSS for the period, and annual SSC loads were significantly higher than TSS loads during all 3 years. TSS and SSC loads were statistically similar between 2014 and 2015, despite substantially higher runoff in 2015, and were significantly higher than in 2016 when conditions were dry. Sediment loads varied greatly between years. TSS and SSC loads were 89.6 and 118 percent higher, respectively, in 2015 (wet conditions) than in 2016 (dry conditions), while runoff was only 48.4 percent higher in 2015 than in 2016 (table 17).
TN loads were significantly lower in the dry year (2016), whereas $\mathrm{NO}_{3}+\mathrm{NO}_{2}$ loads were similar across all years (fig. 28C). $\mathrm{NO}_{3}+\mathrm{NO}_{2}$ represents 39.4 percent of $\mathrm{TN}$ over these 3 years. TP loads were not significantly different across years; however, the DP load was significantly lower in 2016 than in the other 2 years (fig. 28D). DP represents 21.2 percent of TP. Annual TOC, $\mathrm{Ca}, \mathrm{TPb}, \mathrm{TZn}$, and TDS loads all varied with precipitation, with the lowest in the dry year (2016) and the highest in the wet year (2015; figs. $28 E-G$; table 17). The Mg load was significantly higher in 2015 (when runoff was highest) than in the other 2 years. TCu loads were similar among the 3 years.

Constituents that have the largest variations in annual loads include COD, SSC, TSS, and trace metals, as indicated by the percentage differences in annual loads between 2016 and 2015, ranging from 74.0 to 118 percent (table 17). The percentage differences for these constituents well exceeded the 48.4 percent higher runoff in 2015 than in 2016. These larger differences are the result of having substantially higher concentrations of these constituents in stormflow (figs. 26C, F, G, $S, T$, and $U$ ) combined with higher proportions of stormflow in runoff in 2015 than in 2016, as indicated by the study watersheds' BFIs of 0.41 in 2015 and 0.49 in 2016 (fig. 18).

Annual average concentration, the annual load divided by annual runoff, is used to remove the effects of variations in the quantity of runoff in order to distinguish variations in concentrations. Constituents that have substantially higher concentrations during stormflow (fig. 26) generally have higher concentrations in wetter years when BFIs are low (fig. 18)

Table 17. Annual constituent loads, precipitation, and runoff for the study watersheds in DeKalb County, Georgia, 2014-16.

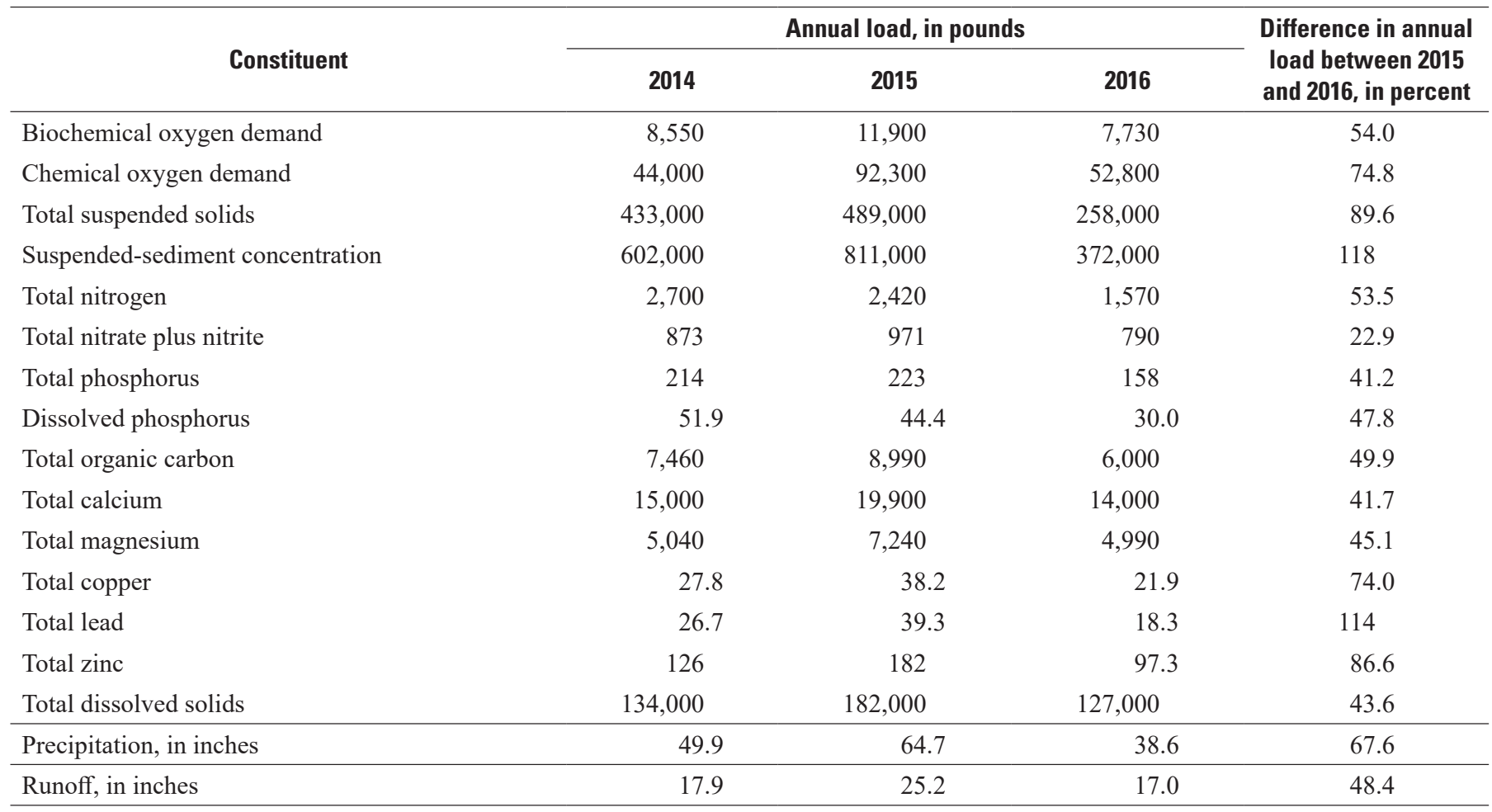



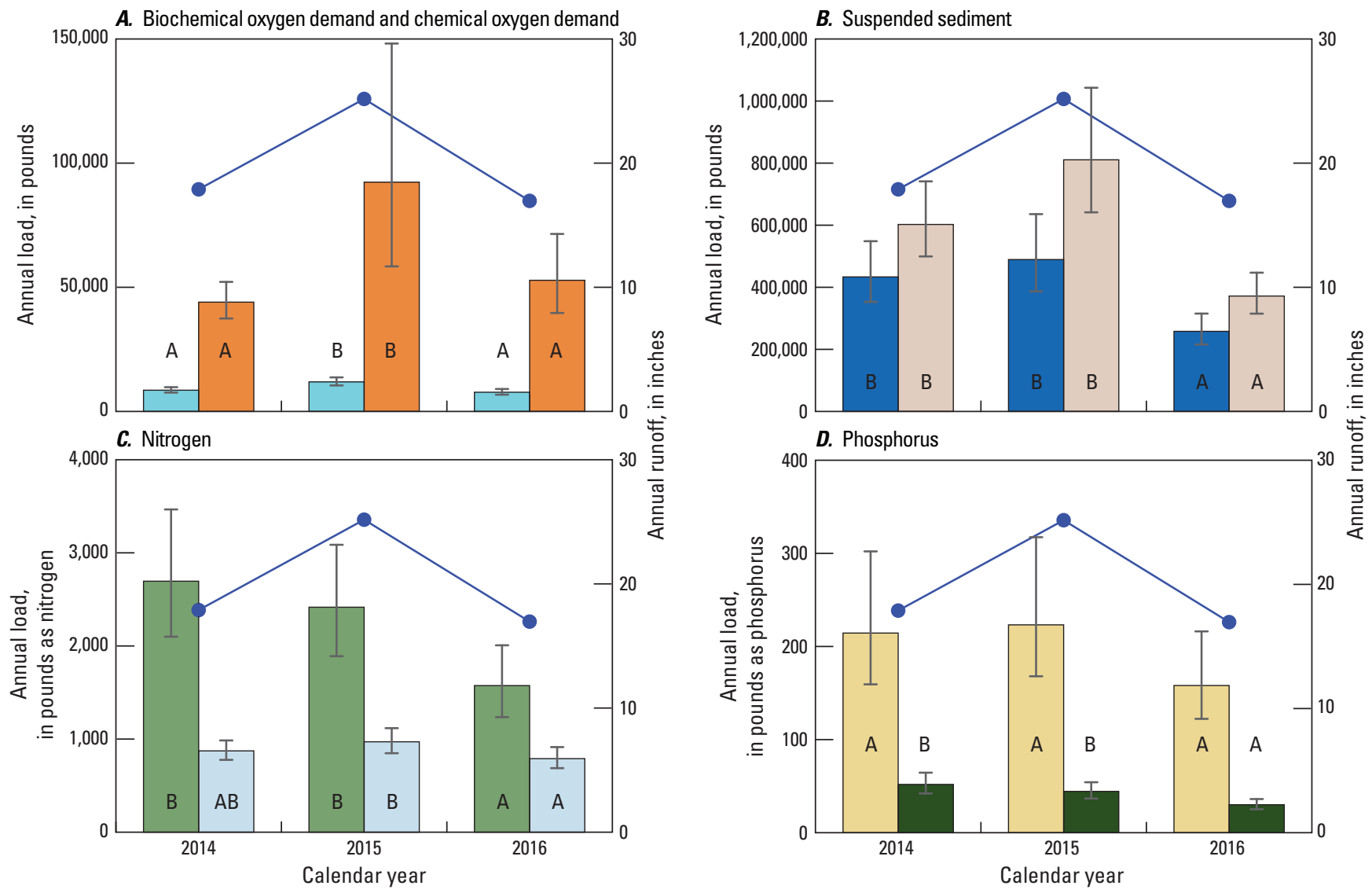

EXPLANATION

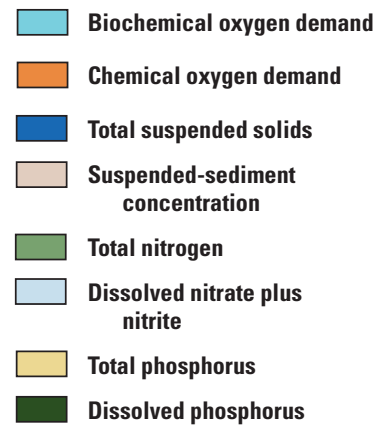

Confidence interval

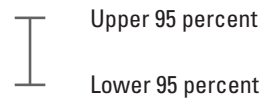

- Runoff

A Letters are used for comparing yields. Yields that do not share the same letter are significantly different ( $p$-value $\leq 0.05$ )

Figure 28. Annual runoff and annual loads of $A$, biochemical and chemical oxygen demand, $B$, suspended sediment, $C$, nitrogen, $D$, phosphorus, $E$, total organic carbon, $F$, total calcium and magnesium, $G$, trace metals, and $H$, total dissolved solids for 15 monitored watersheds in DeKalb County, Georgia, 2014-16. 

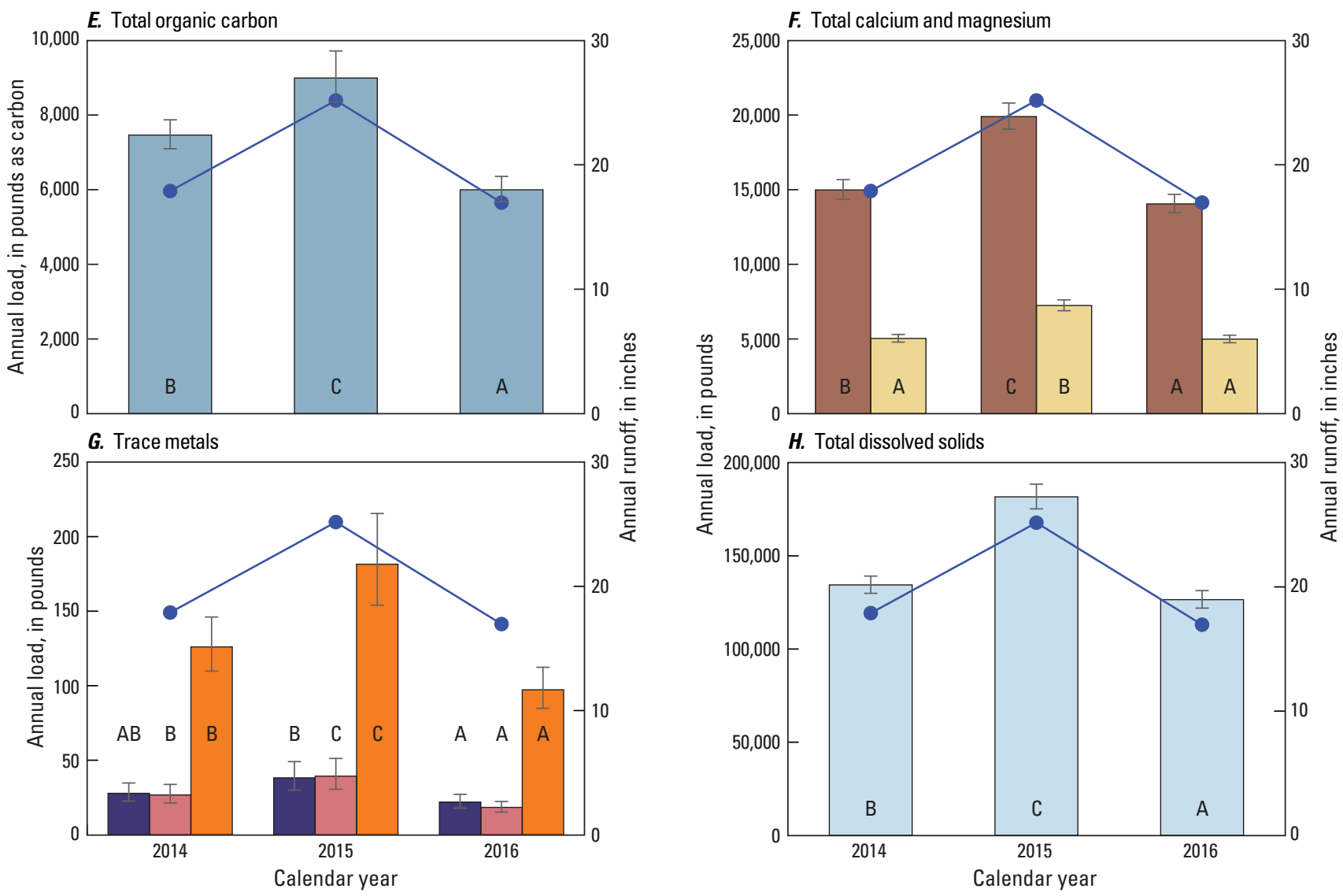

\section{EXPLANATION}

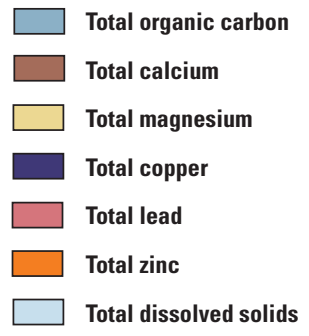

Confidence interval

T Upper 95 percent

$\perp \quad$ Lower 95 percent

- Runoff

A Letters are used for comparing yields. Yields that do not share the same letter are significantly different ( $p$-value $\leq 0.05)$

Figure 28. Annual runoff and annual loads of $A$, biochemical and chemical oxygen demand, $B$, suspended sediment, $C$, nitrogen, $D$, phosphorus, $E$, total organic carbon, $F$, total calcium and magnesium, $G$, trace metals, and $H$, total dissolved solids for 15 monitored watersheds in DeKalb County, Georgia, 2014-16.-Continued

because a higher proportion of runoff occurs as stormflow. $\mathrm{SSC}, \mathrm{TPb}$, and $\mathrm{TZn}$, which all increase with streamflow, had similar average annual concentrations during the years with higher runoff (2014 and 2015); average annual concentrations were significantly lower in 2016, the dry year. BFIs were 0.41 in 2014 and 2015. Average annual concentrations of BOD, $\mathrm{COD}, \mathrm{TP}, \mathrm{Ca}, \mathrm{Mg}, \mathrm{TCu}$, and TDS were not significantly different during 2014-16 (figs. 29A-H). BOD, COD, TP, and TCu concentrations are higher during stormflow than during base flow, Ca concentrations are lower during stormflow, and $\mathrm{Mg}$ and TDS concentrations are lower or similar during stormflow (fig. 26). TN, DP, and TOC had significantly higher average annual concentrations in 2014, which had average precipitation. Annual average concentrations for TSS and $\mathrm{NO}_{3}+\mathrm{NO}_{2}$ had no clear patterns. 

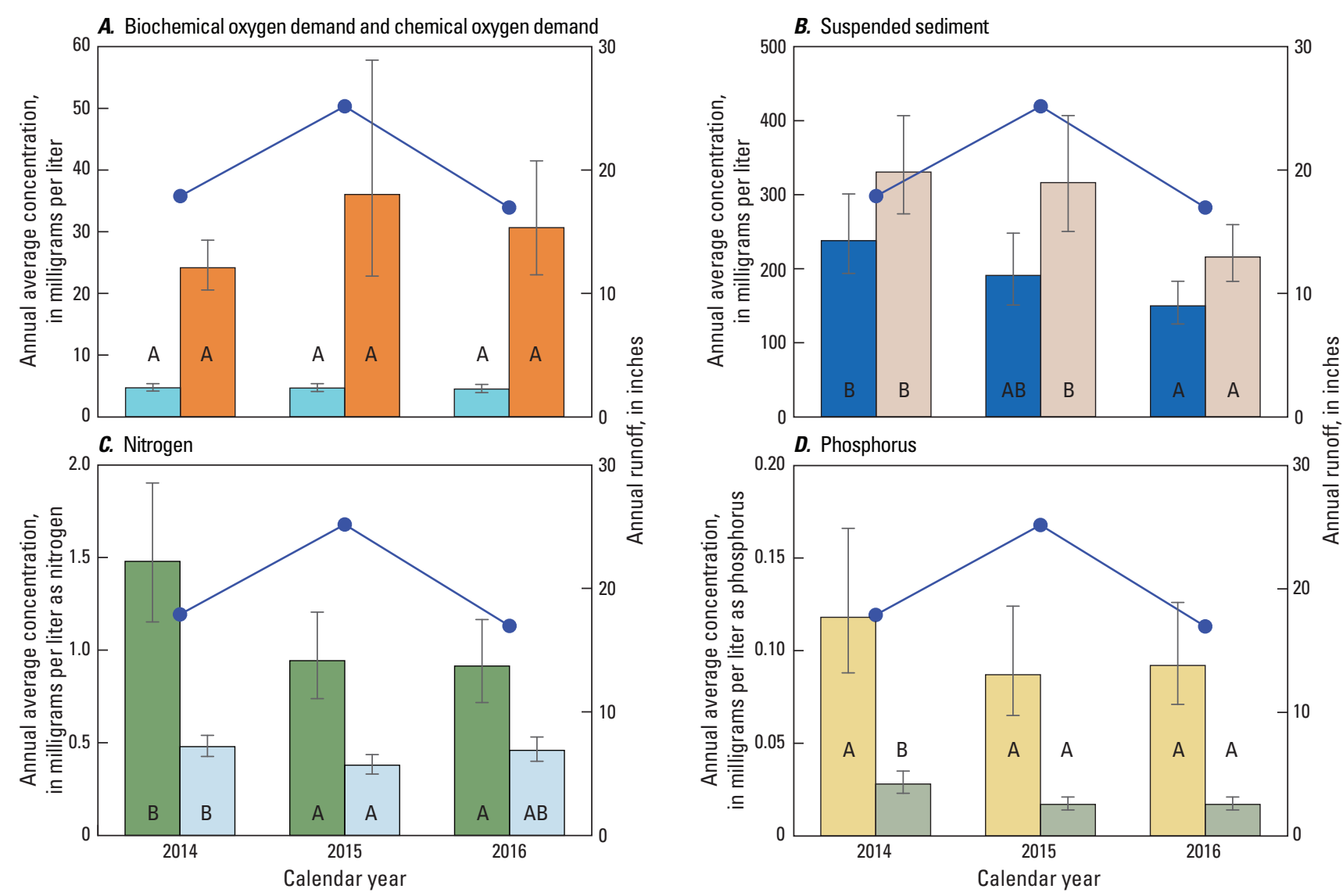

\section{EXPLANATION}

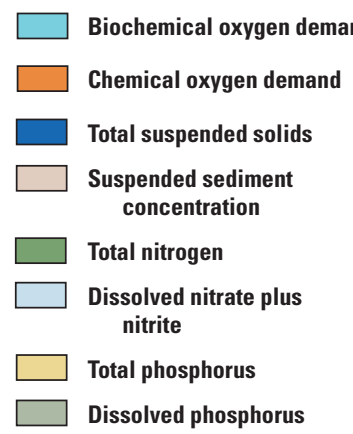

Confidence interval

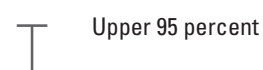

$\perp \quad$ Lower 95 percent

- Runoff

A Letters are used for comparing annual average concentrations. Concentrations that do not share the same letter are significantly different ( $p$-value $\leq 0.05$ )

Figure 29. Annual average concentrations of $A$, biochemical and chemical oxygen demand, $B$, suspended sediment, $C$, nitrogen, $D$, phosphorus, $E$, total organic carbon, $F$, total calcium and magnesium, $G$, trace metals, and $H$, total dissolved solids for the 15 monitored watersheds in DeKalb County, Georgia, 2014-16. 

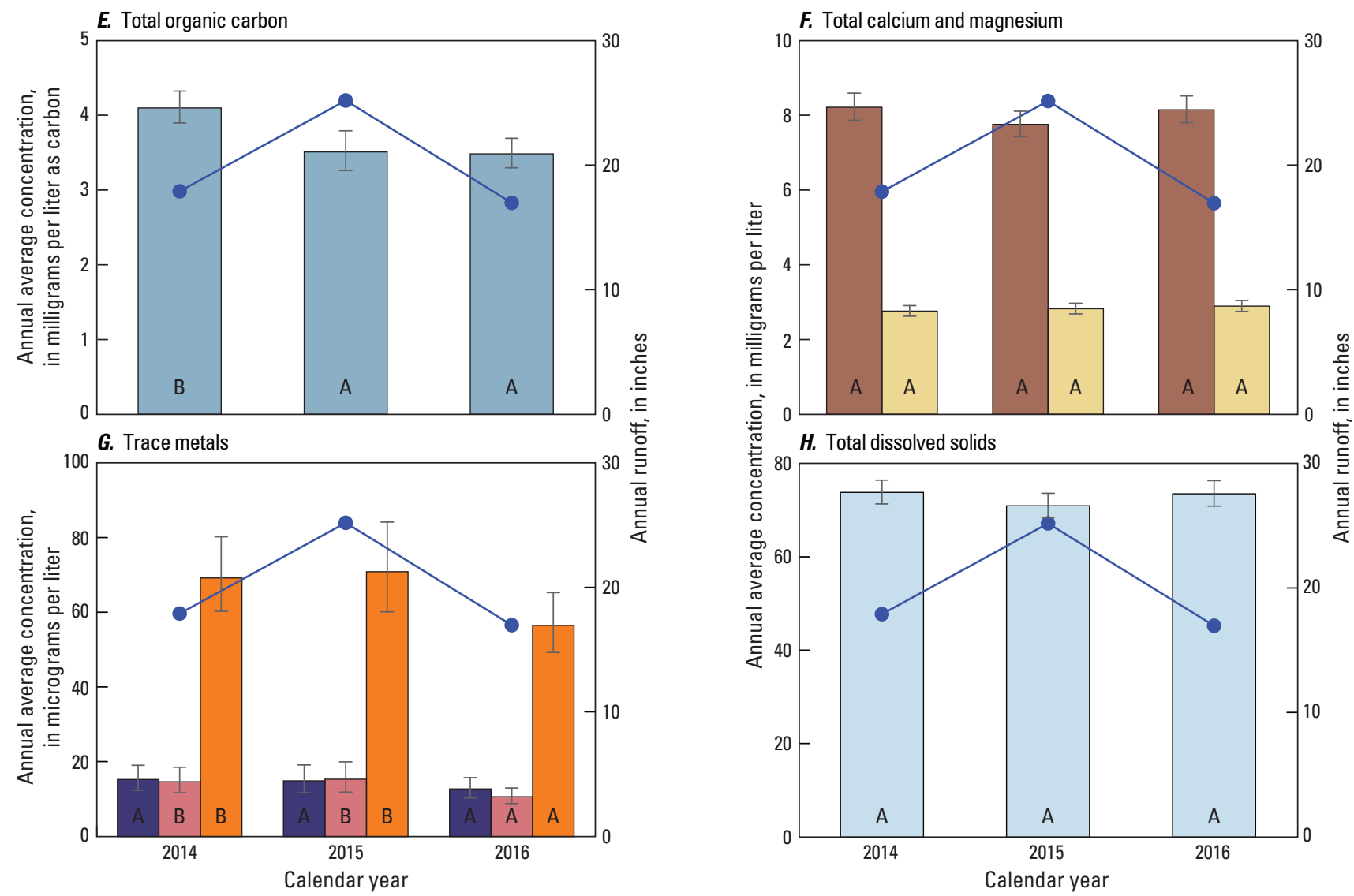

EXPLANATION

\begin{tabular}{|c|}
\hline Total organic carbon \\
\hline Total calcium \\
\hline Total magnesium \\
\hline Total copper \\
\hline Total lead \\
\hline Total zinc \\
\hline Total dissolved solids \\
\hline
\end{tabular}

Confidence interval

T Upper 95 percent

L Lower 95 percent

- Runoff

A Letters are used for comparing annual average concentrations. Concentrations that do not share the same letter are significantly different ( $p$-value $\leq \mathbf{0 . 0 5}$ )

Figure 29. Annual average concentrations of $A$, biochemical and chemical oxygen demand, $B$, suspended sediment, $C$, nitrogen, $D$, phosphorus, $E$, total organic carbon, $F$, total calcium and magnesium, $G$, trace metals, and $H$, total dissolved solids for the 15 monitored watersheds in DeKalb County, Georgia, 2014-16.-Continued

\section{Watershed Constituent Yields}

Constituent yields-loads per unit area-are summarized for 15 constituents, by watershed, for the period 2014-16 in figure 30. The more notable differences in yields are discussed herein. BOD yields were lowest from the Stone Mountain Creek watershed and highest from the Intrenchment Creek watershed (fig. 30A). COD yields were lowest from the Pole Bridge Creek, Stone Mountain Creek, South Fork Peachtree Creek at Johnson Road, and Nancy Creek watersheds, and highest from the Intrenchment Creek and South River watersheds.
TSS and SSC yields were lowest from the Stone Mountain Creek watershed and were also low from the Doolittle Creek and Pole Bridge Creek watersheds (fig. 30B). TSS and SSC yields were highest from the Intrenchment Creek and Cobbs Creek watersheds. SSC yields were significantly higher than TSS yields from six watersheds (Shoal Creek, Cobbs Creek, South River, Snapfinger Creek at Thompson Mill Road, Stone Mountain Creek, and South Fork Peachtree Creek at Johnson Road), and yields were similar from the remaining eight watersheds that have uncertainty estimates. Sediment in watersheds with higher SSC yields likely had a greater proportion of sand-sized material (Gray and others, 2000). 

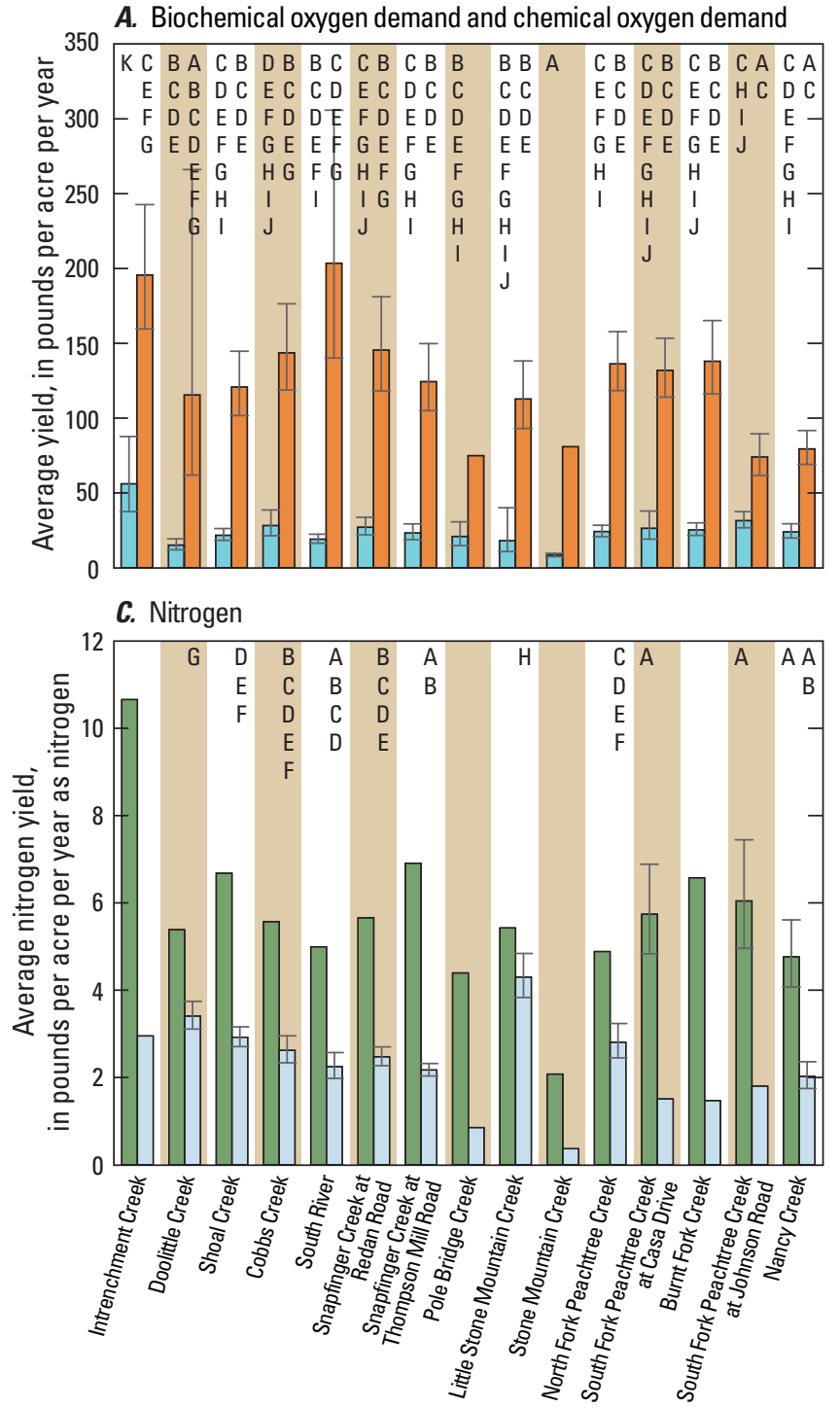
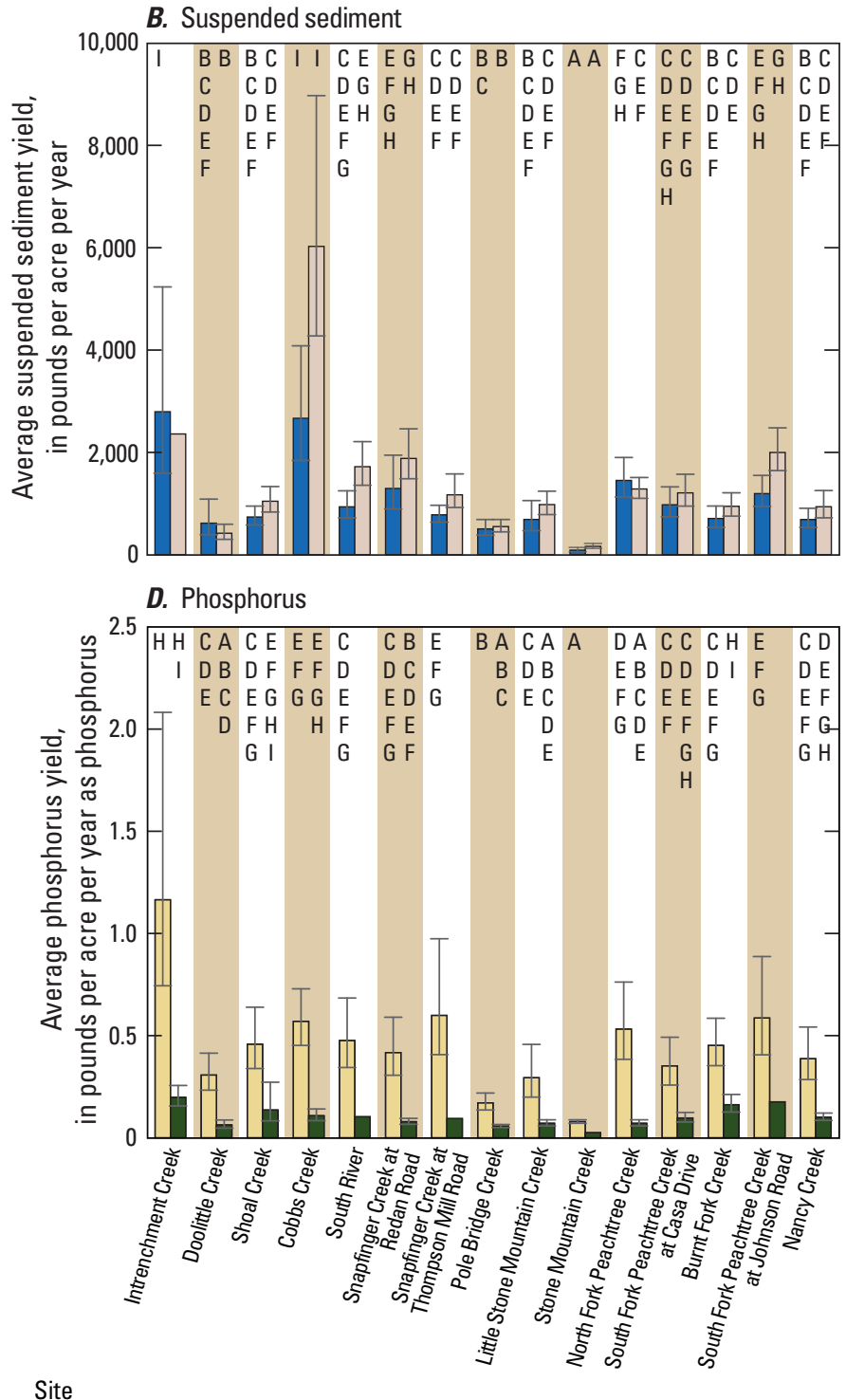

EXPLANATION

Confidence interval

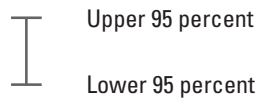

$H \quad$ Letters are used for comparing yields.

Yields that do not share the same

letter are significantly different

( $p$-value $\leq 0.05)$

$\square$ Total nitrate plus nitrite

$\square$ Total phosphorus

$\square$ Dissolved phosphorus

Figure 30. Annual yields of $A$, biochemical and chemical oxygen demand, $B$, suspended sediment, $C$, nitrogen, $D$, phosphorus, $E$, total organic carbon, $F$, total calcium and magnesium, $G$, trace metals, and $H$, total dissolved solids for 15 monitored watersheds in DeKalb County, Georgia, 2014-16. 

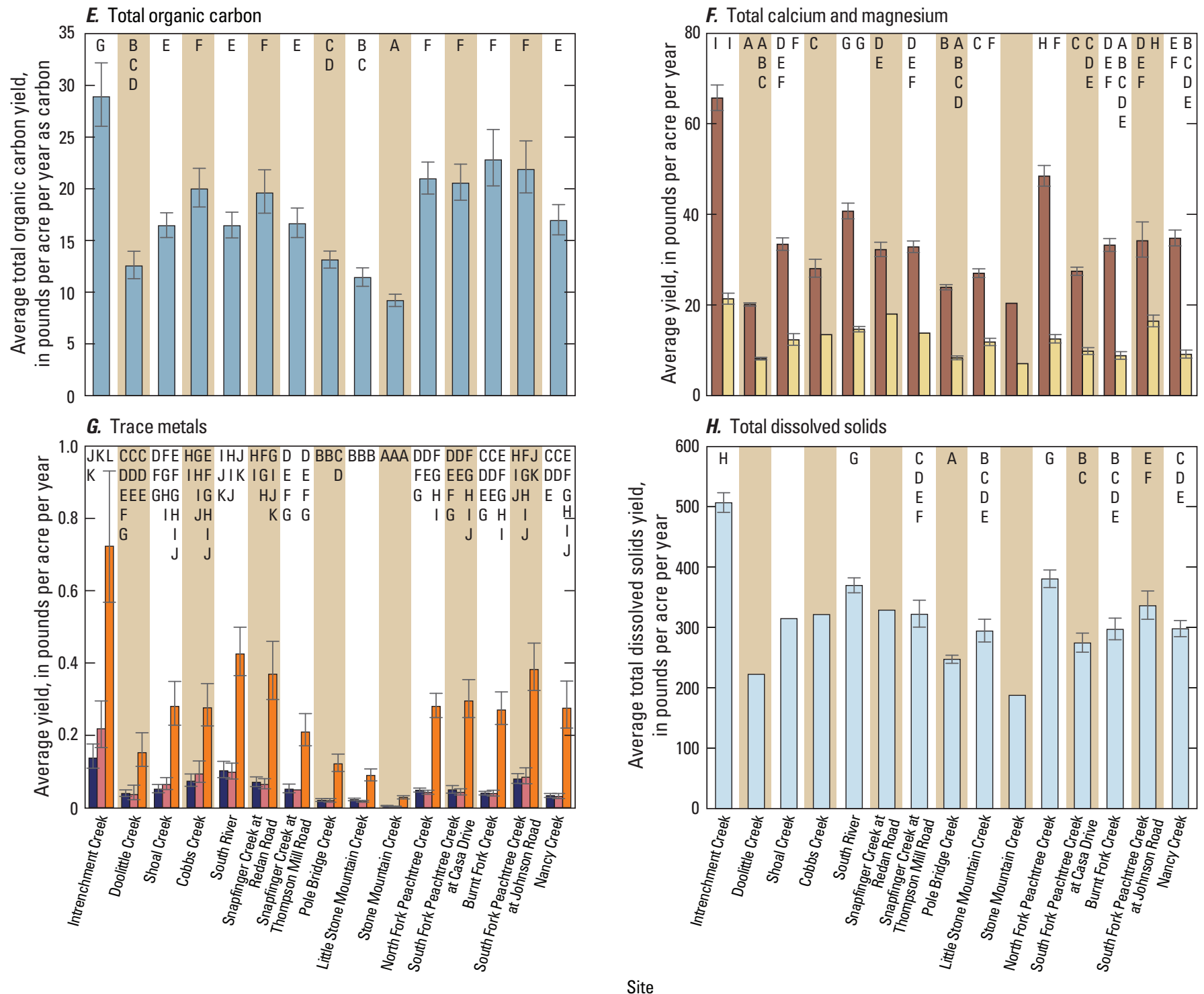

\section{EXPLANATION}

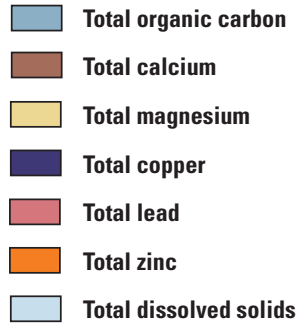

Confidence interval

T Upper 95 percent

$\perp \quad$ Lower 95 percent

H Letters are used for comparing yields.

Yields that do not share the same

letter are significantly different

( $p$-value $\leq 0.05$ )

Figure 30. Annual yields of $A$, biochemical and chemical oxygen demand, $B$, suspended sediment, $C$, nitrogen, $D$, phosphorus, $E$, total organic carbon, $F$, total calcium and magnesium, $G$, trace metals, and $H$, total dissolved solids for 15 monitored watersheds in DeKalb County, Georgia, 2014-16.-Continued 
TN yields were lowest from the Stone Mountain Creek watershed and highest from the Intrenchment Creek watershed (fig. 30C). $\mathrm{NO}_{3}+\mathrm{NO}_{2}$ yields were lowest from the Stone Mountain Creek watershed and were also low from the Pole Bridge Creek watershed. $\mathrm{NO}_{3}+\mathrm{NO}_{2}$ yields were highest from the Little Stone Mountain Creek watershed, which was almost entirely composed of medium-density residential (95.5 percent; fig. 6). The TP yield was lowest from the Stone Mountain Creek watershed, and the TP yield was also low from the Pole Bridge Creek watershed (fig. 30D). The TP yield was highest from the Intrenchment Creek watershed. The DP yield was lowest from the Stone Mountain Creek watershed, and DP yields were also low from the Doolittle Creek and Pole Bridge Creek watersheds. DP yields were highest from the Intrenchment Creek, Shoal Creek, and Burnt Fork Creek watersheds, but yields were similar to those from several other watersheds. TP and DP yields had a similar pattern among watersheds despite DP only making up a small portion of TP (21.2 percent). The Stone Mountain Creek and Pole Bridge Creek watersheds consistently had among the lowest nitrogen and phosphorus nutrient yields. Low nutrient yields from the Stone Mountain Creek watershed are likely the result of in-lake processes in the large reservoir that drains a large portion of this watershed. Low annual nutrient yields in the Stone Mountain Creek and Pole Bridge Creek watersheds appear to be related to higher percentages of the forest/park/ agriculture land use group (29.9 and 19.5 percent, respectively; fig. 6). Forested areas in the study region typically have low nutrient yields (Aulenbach, 2020). Agricultural areas, however, can be substantial sources of nutrients, but they only compose 0.14 percent of the study area (Atlanta Regional Commission, 2012).

TOC yields were lowest from the Stone Mountain Creek watershed, low from the Little Stone Mountain Creek watershed, and highest from the Intrenchment Creek watershed (fig. 30E). Ca, Mg, and TDS yields were lowest from the Doolittle Creek, Pole Bridge Creek, and Stone Mountain Creek watersheds (figs. $30 F$ and $H$ ). $\mathrm{Ca}, \mathrm{Mg}$, and TDS yields were highest from the Intrenchment Creek watershed, and yields were also high for $\mathrm{Ca}$ and TDS from the South River and North Fork Peachtree Creek watersheds. Mg yields were high from the South River and South Fork Peachtree Creek at Johnson Road watersheds. Higher $\mathrm{Ca}, \mathrm{Mg}$, and TDS yields appear to be associated with larger watersheds; the South River, North Fork Peachtree Creek, and South Fork Peachtree Creek at Johnson Road watersheds represent three of the four largest drainage areas in this study (table 7).

Trace metal yields were lowest from the Stone Mountain Creek watershed and also low from the Little Stone Mountain Creek and Pole Bridge Creek watersheds (fig. 30G). Trace metal yields were highest from the Intrenchment Creek, South River, South Fork Peachtree Creek at Johnson Road watersheds for all three trace metals. $\mathrm{TCu}$ and $\mathrm{TPb}$ yields were high from the Cobbs Creek watershed, and the TZn yield was high from the Snapfinger Creek at Redan Road watershed.

\section{Correlations in Watershed Constituent Yields}

Correlations in constituent yields among watersheds could be an indication of similar or associated sources, controls, or transport of constituents within the study watersheds. Significant inherent correlations between watershed constituent yields and runoff, however, can cause incidental correlations between constituents because similar characteristics of runoff can affect constituent yields similarly. Hence, only correlations between constituent yields that are substantially stronger than those observed with runoff are likely to be indicative of constituent-related associations.

Correlations of watershed yields with runoff were strongest for TP (0.737), $\mathrm{Mg}(0.709)$, and TDS (0.758) and were not significant for $\mathrm{COD}, \mathrm{SSC}$, and $\mathrm{NO}_{3}+\mathrm{NO}_{2}$ (table 18). Correlations between constituents were very strong $(r>0.9)$ between the trace metals, and between BOD and TP, TP and $\mathrm{TPb}, \mathrm{TP}$ and TDS, and $\mathrm{Ca}$ and TDS. Correlations were also high $(r>0.8)$ for BOD and a majority of the constituents and for TP and a majority of the constituents. Most combinations of $\mathrm{Ca}, \mathrm{Mg}$, TDS, and trace metals also had high correlations. The correlations of BOD with nutrients are expected because BOD represents the amount of oxygen necessary to break down all organic compounds-including nutrients.

Variations in watershed TP are correlated with variations in other predominantly particulate constituents and other nutrients. The correlations between predominantly dissolvedphase $\mathrm{Ca}$ and $\mathrm{Mg}$ and TDS versus predominantly particulatephase trace metals (as indicated by the near ubiquitous use of the turbidity explanatory variable in the LOADEST models for these constituents, table 15) were unexpected. These correlations could just be incidental, resulting from watershed characteristics that affect these dissolved and particulate-phase constituents in the study area.

$\mathrm{NO}_{3}+\mathrm{NO}_{2}$ yields were not significantly correlated with any other constituents, and SSC was only significantly correlated with TSS and TCu. The lack of significant correlations with $\mathrm{NO}_{3}+\mathrm{NO}_{2}$ may indicate differing sources, controls, and (or) transport mechanisms than those of the other constituents. The lack of significant SSC correlations may be due to the presence of greater proportions of sand-sized material at only some of the watersheds which was quantified by SSC but was not reflected in the yields of other constituents. 
Table 18. Correlation coefficients between constituent yields and runoff for the 15 study watersheds in DeKalb County, Georgia, 2014-16.

[BOD, biochemical oxygen demand; $\mathrm{COD}$, chemical oxygen demand; TSS, total suspended solids; $\mathrm{SSC}$, suspended-sediment concentration; $\mathrm{TN}$, total nitrogen; $\mathrm{NO}_{3}+\mathrm{NO}_{2}$, total nitrate plus nitrite; $\mathrm{TP}_{\text {, total }}$ phosphorus; DP, dissolved phosphorus; TOC, total organic carbon; Ca, total calcium; Mg, total magnesium; TCu, total copper; TPb, total lead; TZn, total zinc; TDS, total dissolved solids; - , results not listed for duplicative combinations; Statistically significant Pearson product-moment correlation coefficients in bold font ( $p$-value is less than or equal to 0.05$)$ ]

\begin{tabular}{|c|c|c|c|c|c|c|c|c|c|c|c|c|c|c|c|c|}
\hline Constituent & BOD & COD & TSS & SSC & TN & $\mathrm{NO}_{3}+\mathrm{NO}_{2}$ & TP & DP & TOC & Ca & $\mathbf{M g}$ & $\mathrm{TCu}$ & $\mathrm{TPb}$ & TZn & TDS & Runoff \\
\hline BOD & 1 & - & - & - & - & - & - & - & - & - & - & - & - & - & - & - \\
\hline COD & 0.469 & 1 & - & - & - & - & - & - & - & - & - & - & - & - & - & - \\
\hline TSS & 0.807 & 0.576 & 1 & - & - & - & - & - & - & - & - & - & - & - & - & - \\
\hline $\mathrm{SSC}$ & 0.430 & 0.372 & 0.823 & 1 & - & - & - & - & - & - & - & - & - & - & - & - \\
\hline $\mathrm{TN}$ & 0.872 & 0.553 & 0.641 & 0.276 & 1 & - & - & - & - & - & - & - & - & - & - & - \\
\hline $\mathrm{NO}_{3}+\mathrm{NO}_{2}$ & 0.196 & 0.363 & 0.342 & 0.210 & 0.424 & 1 & - & - & - & - & - & - & - & - & - & - \\
\hline TP & 0.913 & 0.618 & 0.811 & 0.462 & 0.896 & 0.351 & 1 & - & - & - & - & - & - & - & - & - \\
\hline DP & 0.788 & 0.361 & 0.538 & 0.331 & 0.808 & 0.142 & 0.789 & 1 & - & - & - & - & - & - & - & - \\
\hline TOC & 0.892 & 0.520 & 0.749 & 0.448 & 0.767 & 0.084 & 0.845 & 0.821 & 1 & - & - & - & - & - & - & - \\
\hline $\mathrm{Ca}$ & 0.807 & 0.630 & 0.648 & 0.210 & 0.714 & 0.261 & 0.874 & 0.634 & 0.773 & 1 & - & - & - & - & - & - \\
\hline $\mathrm{Mg}$ & 0.771 & 0.588 & 0.723 & 0.473 & 0.702 & 0.374 & 0.820 & 0.594 & 0.670 & 0.728 & 1 & - & - & - & - & - \\
\hline $\mathrm{TCu}$ & 0.796 & 0.760 & 0.771 & 0.522 & 0.737 & 0.273 & 0.871 & 0.705 & 0.757 & 0.771 & 0.873 & 1 & - & - & - & - \\
\hline $\mathrm{TPb}$ & 0.880 & 0.689 & 0.820 & 0.507 & 0.811 & 0.266 & 0.921 & 0.734 & 0.757 & 0.806 & 0.835 & 0.951 & 1 & - & - & - \\
\hline $\mathrm{TZn}$ & 0.886 & 0.682 & 0.728 & 0.385 & 0.784 & 0.193 & 0.887 & 0.779 & 0.866 & 0.861 & 0.827 & 0.945 & 0.928 & 1 & - & - \\
\hline TDS & 0.850 & 0.694 & 0.762 & 0.406 & 0.784 & 0.387 & 0.924 & 0.690 & 0.803 & 0.954 & 0.860 & 0.869 & 0.869 & 0.898 & 1 & - \\
\hline Runoff & 0.613 & 0.392 & 0.616 & 0.496 & 0.571 & 0.170 & 0.737 & 0.532 & 0.627 & 0.663 & 0.709 & 0.675 & 0.623 & 0.655 & 0.758 & 1 \\
\hline
\end{tabular}




\section{Discussion}

Further interpretation of the relations between watershed BFIs and runoff ratios versus watershed percentage impervious area are provided. Possible cause and effect relations between watershed drainage area, annual runoff variations, climate, and land use on watershed constituent concentrations and yields are discussed. Inferences regarding possible constituent sources and transport mechanisms were made based on attributes of watershed constituent yields, land use, and specific watershed characteristics, such as the presence of reservoirs and combined sewers. To provide further perspective of the DeKalb County study results, comparisons between relations of watershed BFIs and runoff ratios versus impervious area and comparisons of watershed constituent yields were made with results of a similar study of 13 urban watershed in adjacent Gwinnett County, Georgia. Assessments of uncertainty and potential biases in load estimates are evaluated, including the implications of various methodology decisions and the benefits of using turbidity as a surrogate model variable.

\section{Relations Among Watershed Characteristics, Runoff Metrics, and Constituent Yields}

The only watershed characteristics that were significantly correlated with runoff metrics were the various permutations of imperviousness (table 11). Watershed imperviousness had the strongest correlations with its runoff ratio $(r=0.646$; fig. $21 B)$ and BFI ( $r=-0.898$; fig. 20A). The moderate positive correlation with the runoff ratio likely reflects increases in surface runoff and decreases in infiltration of precipitation on impervious surfaces. Whereas the runoff ratio includes runoff from storms and base flow, the proportion of base flow decreases with increases in imperviousness (as indicated by the relation with BFI), indicating that storm runoff increased. Increases in storm runoff associated with larger percentages of imperviousness have been well documented in many urban studies (Leopold, 1968; Hollis, 1975; Ogden and others, 2011). The strong negative correlation between imperviousness and BFI is likely due to decreased infiltration of precipitation lessening groundwater recharge and reducing stream base flow (Simmons and Reynolds, 1982). BFI is also affected by the proportion of runoff that occurs as stormflow, which may explain why BFI had a particularly strong (inverse) relation with imperviousness.

Although stormwater BMPs have been implemented in the study watersheds, the effects of imperviousness on storm runoff and base flow are still apparent. The BMPs do not appear to fully mitigate the effects of urban development and land use on stream hydrology in these basins; however, this study did not explicitly evaluate the effectiveness of BMPs. Significant relations were not identified between other watershed characteristics and runoff metrics, but these characteristics could still be affecting hydrology. For some characteristics, such as average land-surface slope and topographic wetness (fig. 5; table 7), variability between watersheds was quite small. A multivariate analysis may be necessary to tease out the effects of other watershed characteristics on runoff metrics. Differences in watershed BMP implementation and infrastructure can also affect hydrologic responses and may obscure relations with the watershed characteristics quantified in this study.

Substantial variations in annual loads were observed, with the largest variations occurring for COD, SSC, TSS, and trace metals (fig. 28; table 17). Annual runoff and climate have a substantial role in the variability in annual loads. Annual loads are typically higher in years when runoff is larger and climate is wetter. TP was the only constituent load not significantly different between the wettest (2015) and driest (2016) years (fig. 28D). Meeting water-quality regulatory standards for loads is more difficult to achieve in years that are particularly wet.

Several constituent concentrations and yields appear to be generally higher for watersheds with larger drainage areas. Results from Intrenchment Creek were excluded from this discussion because of its considerably higher concentrations relative to the other study watersheds. The four sites with the highest base-flow SC values (fig. 26A; South River, North Fork Peachtree Creek, South Fork Peachtree Creek at Johnson Road, and Nancy Creek) had four of the six largest drainage areas (table 7). TOC concentrations in base-flow samples were lowest at the Doolittle Creek, Cobbs Creek, and Little Stone Mountain Creek sites (fig. 26N), which had three of the five smallest drainage areas in the study. Higher $\mathrm{Ca}, \mathrm{Mg}$, and TDS yields were associated with three of the four watersheds with the largest drainage areas (South River, North Fork Peachtree Creek, and South Fork Peachtree Creek at Johnson Road; figs. $30 F$ and $H$ ). The positive relation of drainage area to constituent concentrations and annual yields may be the result of longer groundwater residency time which can alter water chemistry by increasing the concentration of geological weathering-derived solutes (Maher, 2010, 2011). Ca, Mg, and dissolved organic carbon (DOC; comparable to TOC) yields from the Panola Mountain Research Watershed (PMRW; fig. 1), a small, 0.16- $\mathrm{mi}^{2}$, forested catchment, are 4.94, 2.30, and 7.89 pounds per acre per year ([lb/acre $] / \mathrm{yr})$, respectively, for water years 2014 through 2016 (Aulenbach, 2019; a water year is the period from October 1 to September 30 and is designated by the year in which the period ends). These yields were lower than the yields observed for all 15 study watersheds and are consistent with the pattern of lower yields in smaller watersheds. The PMRW is potentially an appropriate reference site for the DeKalb County watersheds because it is undeveloped, has a higher percentage of forested land use, and is in adjacent Rockdale County in the South River Basin.

The $\mathrm{NO}_{3}+\mathrm{NO}_{2}$ yield from PMRW was 0.22 (lb/acre)/yr for water years 2014 through 2016 (Aulenbach, 2019). This is substantially lower than $\mathrm{NO}_{3}+\mathrm{NO}_{2}$ yields in the study watersheds, except for Stone Mountain Creek (0.37 [1b/acre]/yr; 
fig. 30 C). This indicates that $\mathrm{NO}_{3}+\mathrm{NO}_{2}$ yields are likely affected by anthropogenic activities associated with most land uses other than forested land use.

Differences between TSS and SSC yields may imply different sources of sediment. SSC yields were significantly higher than TSS yields at six watersheds (Shoal Creek, Cobbs Creek, South River, Snapfinger Creek at Thompson Mill Road, Stone Mountain Creek, and South Fork Peachtree Creek at Johnson Road), an indication of a higher proportion of coarser grained sand-sized material (Gray and others, 2000). The lack of correlation of watershed SSC yields versus watershed runoff, TSS, and other constituent yields (table 18) infers that the contribution of the coarser grained material varies by watershed. No particular watershed characteristic was significantly correlated with the ratio of SSC to TSS yields. SSC concentrations were not consistently higher than TSS concentrations in stormflow samples from watersheds with higher SSC yields, and the conditions where stormflow sample SSC to TSS concentration ratios exceeded 1.5 varied by watershed. At the Cobbs Creek and South River sites, high SSC to TSS ratios typically occurred for the larger storms and rarely occurred for the small storms. Shoal Creek and Stone Mountain Creek had high ratios more often in the winter when conditions were typically wet but also had high ratios over a large range of flows. At South Fork Peachtree Creek at Johnson Road, high ratios were occasionally observed throughout the year and over the range of flows. Snapfinger Creek at Thompson Mill Road frequently had SSC to TSS ratios $>1$, but they were rarely $>1.5$. Differences in storm characteristics for storms with ratios $>1.5$ between watersheds with higher SSC yields indicate that supply (sources) or transport mechanisms of sediment may vary by watershed. Sediment sources include channel erosion, surface runoff, streambank failures, and land-disturbing activities and are likely to vary by land use, basin characteristics, and stream channel morphology. Sediment transport is also dependent upon the characteristics of the larger storms, which are more likely to cause channel erosion and streambank failures and can more efficiently flush sediment that accumulates during intervening periods.

Watershed characteristics can provide insight into why constituent yields are particularly high or low. The Stone Mountain Creek watershed had among the lowest yields for all 15 constituents (fig. 30). Yields of the predominantly particulate-associated constituents from the Stone Mountain Creek watershed were lower than those from the other watersheds by 90.7 percent for TSS, 88.8 percent for SSC, 93.5 percent for $\mathrm{TCu}, 96.3$ percent for $\mathrm{TPb}$, and 91.7 percent for $\mathrm{TZn}$. Whereas a portion of these differences result from the retention of sediment by Stone Mountain Lake, this large reservoir only drains 48.4 percent of the watershed area. However, two additional small, unnamed reservoirs are about 1.5 miles upstream of the watershed outlet on Stone Mountain Creek and its tributary Crooked Creek. The combined drainage areas of these reservoirs represent 94.7 percent of the Stone
Mountain Creek watershed. Despite their size, they appear to be responsible for further reductions in particulate yields. The water quality of the reservoirs themselves could, however, be negatively affected. Whereas the effects on the reservoirs were not assessed in this study, it is reasonable to assume that particulate transport to the reservoirs could be approximated from their reservoir drainage areas and from the constituent yields from other study watersheds that have similar watershed characteristics. Nutrient yields from the Stone Mountain Creek watershed were also relatively low compared to those from the remaining study watershed areas, with yields lower by 60.9 percent for TN, 83.0 percent for $\mathrm{NO}_{3}+\mathrm{NO}_{2}, 83.8$ percent for TP, and 76.0 percent for DP. Reductions in downstream transport of the particulate portion of TN and TP are likely due to retention in the reservoirs. Reductions in yields of the dissolved portion of these constituents likely result from inreservoir processes, such as denitrification of dissolved nitrate into nitrogen gas by microbial activity.

The Little Stone Mountain Creek watershed had some of the lowest yields for BOD, COD, TSS, SSC, TP, DP, TOC, trace metals, and TDS; however, it had the highest $\mathrm{NO}_{3}+\mathrm{NO}_{2}$ yields and the highest portion of $\mathrm{TN}$ as $\mathrm{NO}_{3}+\mathrm{NO}_{2}$ (79.2 percent; fig. 30). The Little Stone Mountain Creek watershed was the smallest watershed in the study (table 7) and had predominantly medium-density residential land use ( 95.5 percent; table 9; fig. 6). Possible $\mathrm{NO}_{3}+\mathrm{NO}_{2}$ sources from this land use group include lawn fertilizers and inadequate performance of septic systems. The lower yields for many of the other constituents indicate that the medium-density residential land use group typically does not have the same sources of constituents that negatively affect water quality as some of the other land use groups.

The Intrenchment Creek watershed consistently had some of the highest yields for all constituents except $\mathrm{NO}_{3}+\mathrm{NO}_{2}$. This watershed had the second highest imperviousness (36.0 percent; fig. 7; table 10), the highest amount of highdensity residential (29.9 percent; fig. 6; table 9) and the fourth highest proportion of the commercial/industrial/institutional (26.0 percent) land use groups among the study watersheds. The upper part of the watershed includes a portion of the City of Atlanta. This is the only watershed that contains an area with extensive combined sewers, though the effects of this on watershed yields are not clear.

Certain types of water-quality issues are often associated with particular land use groups. However, specific constituents and levels of constituents are dependent upon the actual sources within each watershed. The yields can be helpful in source identification; however, the determination of specific sources in the study watersheds is beyond the scope of this study. Combinations of constituents that are correlated (table 18) and vary similarly with source support the possibility of using these data for source identification for categories of constituents, which can be done with multivariate ordination techniques such as a principal component analysis. 


\section{Comparison to Nearby Watershed Study}

A study similar to this one was implemented for 13 urban watersheds in adjacent Gwinnett County, northeast of DeKalb County (Landers and others, 2007; Landers, 2013; Joiner and others, 2014; Aulenbach and others, 2017a). To provide further perspective on the DeKalb County results, hydrologic metrics, imperviousness, and yields for 10 constituents were compared with those from the Gwinnett County watersheds. Data from the Gwinnett County study are available through water year 2015 (Aulenbach and Joiner, 2017).

Moderate to strong relations between the BFI and runoff ratio versus watershed impervious area were evident for DeKalb (figs. 20A and 21B, respectively) and Gwinnett (fig. 31) Counties. Based on the substantial effects of hydrologic conditions on the BFI and the runoff ratio observed in this study (figs. 18 and 15, respectively), periods of comparison were adjusted for when data were available from both studies. The comparison of BFI to impervious area covered the 3-year period 2014-16 (the base flow hydrograph separation calculations for the Gwinnett County watersheds were extended through the end of 2016 for this analysis), and the comparison of the runoff ratio to impervious area covered the 2-year period October 2013 through September 2015. The Gwinnett County BFI relation to impervious area had a similar slope to that of the DeKalb County relation but had higher BFIs for the same percentage of impervious area, indicating that a larger proportion of runoff occurred as base flow (fig. 31A). The comparison of the relations between runoff ratio and impervious area indicated that Gwinnett County had higher runoff ratios for the same percentage of impervious area, particularly for higher impervious areas (fig. 31B). The slope was steeper for Gwinnett County but was highly influenced by the two watersheds with the highest impervious areas. When excluding these two watersheds, the relations had more similar slopes.

The differences in the relations between the counties' watersheds imply that infiltration and groundwater recharge were higher in the Gwinnett County watersheds for the same percentage of imperviousness. Higher runoff ratios relative to imperviousness in Gwinnett County watersheds were at least partially due to increases in base flow runoff. Lower runoff ratios in DeKalb County watersheds indicate that a larger portion of precipitation is evapotranspired rather than contributed to streamflow. The differences between counties could be caused by differences in watershed characteristics, particular development aspects, and (or) BMP implementation, which have not been assessed. Urbanization occurred earlier in DeKalb County than in Gwinnett County, and BMP requirements, designs, and implementation rates have presumably improved over time such that it might be expected that a greater degree of BMP implementation has occurred in many Gwinnett County watersheds than in DeKalb County watersheds (Aulenbach and others, 2017b).
Watershed yields from the Dekalb County study were compared to those computed for the Gwinnett County study to provide greater perspective of these loading rates. Comparisons between these two studies were available for 10 constituents: TSS, SSC, TN, $\mathrm{NO}_{3}+\mathrm{NO}_{2}$, TP, DP, TOC, TPb, TZn, and TDS (fig. 32). While yields do not cover the exact 2-year period - calendar years 2014 and 2015 for the DeKalb County watersheds and water years 2014 and 2015 for the Gwinnett County watersheds - the comparisons represent similar climatic conditions.
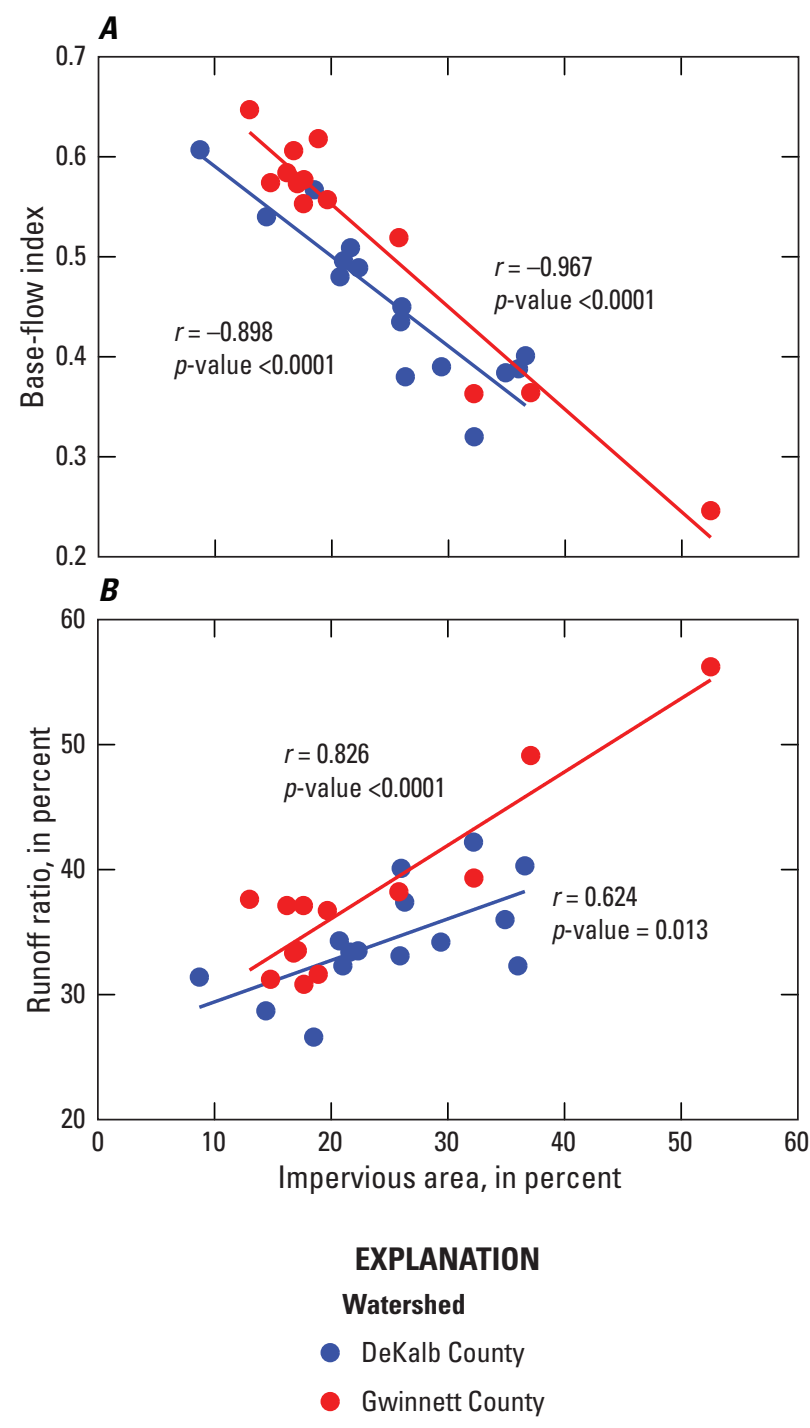

Figure 31. Scatterplots showing $A$, base-flow index (2014 to 2016) and $B$, runoff ratio (October 2013 through September 2015) versus impervious area for the 15 monitored watersheds in DeKalb County, Georgia, and 13 monitored watersheds in Gwinnett County, Georgia (Aulenbach and others, 2017a). Impervious area data are from 2011 for Dekalb County and from 2014 for Gwinnett County. The lines represent a linear fit between the variables. Abbreviations: $r$, Pearson product-moment correlation coefficient; $p$-value, measure of statistical significance of correlation coefficient; <, less than. 


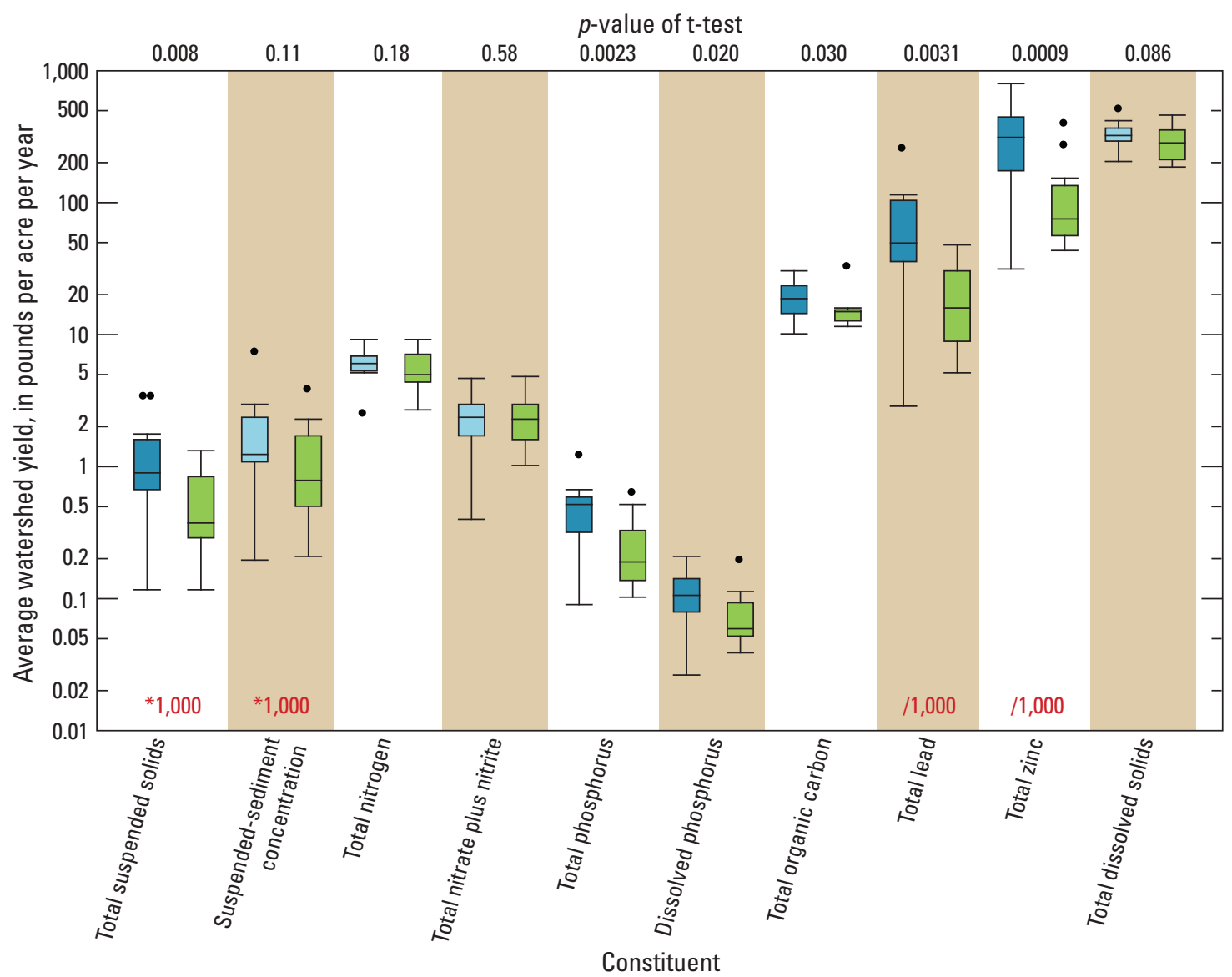

Constituent

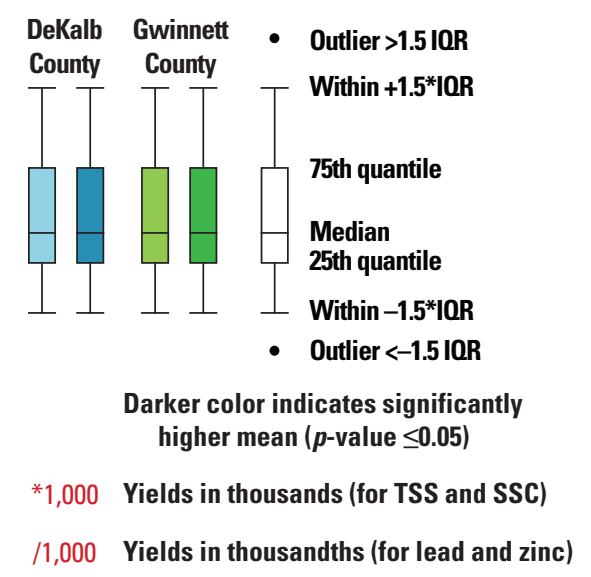

Figure 32. Average watershed yields for the 15 monitored watersheds in DeKalb County, Georgia, 2014-15, and 13 monitored watersheds in Gwinnett County, Georgia (Aulenbach and others, 2017a) for October 2013 through September 2015. Abbreviations: IQR, interquartile range; $p$-value, measure of statistical significance of correlation coefficient; $>$, greater than; $<$, less than; $\leq$, less than or equal to; TSS, total suspended solids; SSC, suspended-sediment concentration. 
The watershed yields between the two studies had overlapping ranges for each constituent (fig. 32). Six of the 10 constituents had significantly higher mean watershed yields in the DeKalb County study (TSS, TP, DP, TOC, TPb, and TZn). The Intrenchment Creek watershed yields were substantially higher than the highest watershed yields observed in the Gwinnett County study for TSS, TP, TPb, and TZn, and the Cobbs Creek watershed yields were substantially higher than the highest watershed yields observed in the Gwinnett County study for TSS and SSC (figs. 30 and 32). The highest watershed yields for the other five constituents were fairly similar between the two studies.

The high $\mathrm{NO}_{3}+\mathrm{NO}_{2}$ yields at the Little Stone Mountain Creek watershed (4.60 [lb/acre]/yr) were similar to the yields at the Yellow River (4.44 [lb/acre]/yr) and Suwannee Creek (4.88 [lb/acre]/yr) watersheds in Gwinnett County. The Yellow River watershed had substantial low density land use (56.36 percent; table 6 in Aulenbach and others, 2017a), which is similar to a combination of the low- and mediumdensity residential land use groups used in the DeKalb County study. This watershed may have similar $\mathrm{NO}_{3}+\mathrm{NO}_{2}$ sources as the Little Stone Mountain Creek watershed, which has 95.5-percent medium-density residential land use.

Intrenchment Creek and North Fork Peachtree Creek at Graves Road watersheds are similar in that they frequently had some of the highest constituent yields among their respective study watersheds. In the DeKalb County study, the Intrenchment Creek watershed had the highest yields for all constituents compared here except for SSC and $\mathrm{NO}_{3}+\mathrm{NO}_{2}$. In the Gwinnett County study, the North Fork Peachtree Creek at Graves Road watershed had the highest yields for TP, DP, TOC, TPb, TZn, and TDS. Constituent yields were fairly similar between the two watersheds except for TSS, SSC, TPb, and TZn, which were substantially higher for the Intrenchment Creek watershed. The North Fork Peachtree Creek at Graves Road watershed had the highest amount of high-density land use in the Gwinnett County study (60.59 percent; land use similar to a combination of commercial/industrial/institutional and high-density residential land use groups used for the DeKalb County study), was urbanized earlier than much of the rest of the county, and had much higher impervious area than any other watersheds in the two studies (52.6 percent in 2014; fig. 12 in Aulenbach and others, 2017a). Intrenchment Creek had a high impervious area (36.0 percent; fig. 7; table 10), but not nearly as high as that of North Fork Peachtree Creek at Graves Road (52.6 percent), and had high amounts of highdensity residential (29.9 percent; fig. 6; table 9) and com$\mathrm{mercial} /$ industrial/institutional (26.0 percent) land use groups. The similarities in land use types and extents suggest possible similarities in activities within these watersheds that resulted in considerably higher constituent yields than those of most of the other watersheds.

Yields from the Stone Mountain Creek watershed were lower, by varying degrees, than yields at any of the Gwinnett County watersheds. The one exception was for TDS, where
Stone Mountain Creek yields were similar to Brushy Fork Creek yields. The Brushy Fork Creek watershed likely had low TDS yields because of its relatively small watershed $\left(8.18 \mathrm{mi}^{2}\right)$, its low percentage of impervious area (14.73), and its high proportion of lower impact land uses (41.13 percent low density and 30.55 estate/park land uses; Aulenbach and others, 2017a). These comparisons point to the effectiveness of the reservoirs in the Stone Mountain Creek watershed in substantially reducing the downstream transport of a wide variety of constituents.

\section{Assessment of Load Estimation Methodology and Uncertainty}

The uncertainty in the estimates of loads and yields in this study is conveyed through the implementation of confidence intervals. Letters have been added to the graphs in figures 28-30 to aid in the determination of significant differences related to watershed characteristics and hydrologic conditions. In the future, with the aid of longer periods of data, the ability to detect whether loads are changing with time is dependent upon the magnitude of the trend with respect to the uncertainty in the load estimates. The LOADEST regressionmodel approach to estimate loads is an empirical (nonprocessbased) approach for which uncertainty is determined by the strength of the fit of model relations. The development of model relations was significantly more challenging because of the use of average stormflow for storm-composite samples, which only incidentally accounts for storm attributes such as duration and peak flow that likely affect loads. Additional uncertainties in load estimation arise from errors, including those inherent in the measurement of stream stage and turbidity, the development and uncertainty in the stage-streamflow relation, the representativeness of the water-quality sampling to actual conditions, and the analytical errors of the laboratory analyses. In a regression-model approach, it is computationally assumed that uncertainties in the models are due to errors in the predicted variables, with no errors in the explanatory variables such as streamflow and turbidity. All errors result in uncertainty in the model relations, however, and are reflected in the model's error estimates. Biases arising from methodology and measurement errors would result in bias in the load estimates. Regression-model error estimates assume that deviations from the model are temporally random, whereas serial correlation in errors is common. Serial correlation can result in load uncertainty to be underestimated at annual time frames if correlations are sufficiently strong (Aulenbach, 2013). The sampling frequency used in this study is insufficient to allow assessment of the inherent level of serial correlation in errors.

The methodology of estimating loads on a time-step basis can introduce biases when storm periods do not conform well with the computational time steps. This issue is assessed in appendix 4: "Assessment of effects of time-step load methodology on load estimates." 
The effects of substituting daily average streamflow for days that were missing unit value streamflows on load estimates were also evaluated. The frequency of substitutions varied by watershed and ranged from 0.04 to 5.97 percent (table 16). While substitutions have little effect on load estimates during stable streamflow conditions, they can bias estimates during more variable, high-frequency events when daily and time-step average streamflows differ more substantially. Load biases are a function of the degree of nonlinearity in the streamflow relation (fig. 3.2), similar to what was found for the time-step methodology problem scenarios. Loads are overestimated for enhancement and underestimated for dilution. The magnitude of error also depended upon the relative magnitude of the change and pattern of streamflow over the day. Substitutions have a larger effect for sites with shorter time steps because these time steps have greater deviations from the daily average streamflow than longer time steps and are from smaller watersheds that have greater short-term variability in streamflow. In future modeling efforts, substitutions should not be an issue because the current USGS Water Mission Area policy for continuous records processing (USGS, 2010) of streamflow data is to estimate unit-value streamflow when data are missing - in contrast to the previous process of only estimating the daily average streamflow (Rantz and others, 1982b).

Errors resulting from extrapolation of the regressionmodel load relations are expected to be minimal because time-step average streamflows infrequently exceeded the range of flows included in the calibration dataset, occurring between 0.03 and 0.68 percent of the time by watershed (table 16). Avoiding using a flow-squared streamflow explanatory variable helped minimize extrapolation issues when extrapolation was necessary.

The inclusion of the turbidity surrogate variable improved model load estimates in multiple ways. Turbidity is a surrogate for suspended sediment and other particulate-related constituents because of the direct relation between the concentration of particulates suspended in the water column and the amount of light scattered (cloudiness; turbidity). The use of turbidity from the in situ water-quality monitors provides a near continuous measure of particulate transport that improves regression modeling over using empirically based explanatory variables such as streamflow. Whereas suspended-sediment concentrations vary with streamflow because of streamflow's relation with stream velocity, there are several other factors that affect suspended-sediment concentrations. Relations between sediment concentrations and streamflow often vary during different portions of the storm hydrograph (fig. $25 A$ ). The relation of sediment with streamflow can change temporally, particularly during and after large storms because of (1) the depletion and replenishment of sediment sources, (2) rearrangement of areas of sediment erosion and aggradation in the stream channel network, (3) discrete streambank failures, and (4) the effects of high rainfall intensity and ensuing surface runoff that washes off particulates. The turbidity surrogate can better capture these changes in sediment transport, which can effectively remove serial correlation in model residuals and alleviate its effects on load uncertainty estimates. However, the surrogate relation with turbidity is not immune to changes because particle-size distributions associated with changes in sediment source can affect turbidity measurements.

When turbidity was a significant explanatory variable in the analyses, the flow-turbidity models outperformed the flow-only models - as indicated by lower residual variance (table 15) - resulting in better load estimates when turbidity was available (table 16). Particulate constituents often have larger load uncertainties than dissolved constituents. This is likely due to a combination of the larger range in observed concentrations for many particulate constituents, sampling errors associated with collecting a representative sample, and the inherent spatial and temporal variations caused by turbulent fluctuations in streamflow and sediment movement (Burkham, 1985). The inclusion of turbidity as an explanatory variable particularly improved model relations for these constituents and compensated for some inherent uncertainty.

\section{Summary}

The U.S. Geological Survey (USGS), in cooperation with DeKalb County Department of Watershed Management, established a long-term water-quantity and water-quality monitoring program in 2012 to monitor and analyze the hydrologic and water-quality conditions of 15 watersheds in DeKalb County, Georgia. DeKalb County is an urban area located in north-central Georgia within the Piedmont physiographic province and includes the easternmost part of the City of Atlanta. The watersheds have varied land use, range in size from 2.19 to 100.01 square miles, and drain into the Chattahoochee, South, and Yellow Rivers. The purpose of this report is to summarize and analyze the hydrologic and waterquality monitoring data collected for the first 5 years of the program, 2012 through 2016.

The study watersheds were continuously monitored for water level (stage), streamflow, precipitation, and waterquality properties (water temperature, specific conductance [SC], dissolved oxygen, $\mathrm{pH}$, and turbidity). Stream-water samples were also collected to characterize the variations in water quality, both hydrologically and seasonally. For each half-year season, summer (May through October) and winter (November through April), three stormflow-composited samples were collected during storm events, and one sample was collected during base-flow conditions for a minimum of eight samples per year. Samples were analyzed for 24 water-quality constituents: SC, biochemical oxygen demand (BOD), chemical oxygen demand (COD), $\mathrm{pH}$, turbidity, total suspended solids (TSS), suspended-sediment concentration (SSC), total nitrogen (TN), total nitrate plus nitrite $\left(\mathrm{NO}_{3}+\mathrm{NO}_{2}\right)$, total ammonia plus organic nitrogen (TKN), dissolved ammonia $\left(\mathrm{NH}_{3}\right)$, total phosphorus (TP), dissolved phosphorus (DP), total organic carbon (TOC), total calcium 
(Ca), total magnesium (Mg), total cadmium (TCd), dissolved cadmium (DCd), total copper (TCu), total lead $(\mathrm{TPb})$, total zinc (TZn), total dissolved solids (TDS), Escherichia coli (E. coli) bacteria, and fecal coliform bacteria.

The 15 study watersheds were characterized for topography (including land-surface elevation, land-surface slopes, and topographic wetness index), land use, percent developed imperviousness, and population density. Watershed average land-surface slopes ranged from 6.5 to 10.3 percent. Land use classifications were combined into a set of eight land use groups. The predominant land uses in the study watersheds were medium-density residential (43.9 percent), commercial/ industrial/institutional (21.4 percent), forest/park/agriculture (13.6 percent), and high-density residential (11.5 percent). Imperviousness in the study watersheds ranged from 8.7 to 36.6 percent. Impervious areas were associated with the commercial/industrial/institutional, transportation/communication/utilities, and high-density residential land use groups. Average watershed population densities ranged from 1,208 to 4,457 people per square mile and were highest in watersheds that contain widespread residential and (or) high-density residential land use.

DeKalb County has a humid, subtropical climate characterized by warm, humid summers and cool, wet winters. Precipitation was monitored at 33 locations throughout the study area including at the watershed outlets. Precipitation averaged 50.7 inches per year during the study period in the study watersheds area. Two years were dry and corresponded with droughts (2012 and 2016), 2 years were wet (2013 and 2015), and 1 year was near average (2014). The average annual runoff for the study watersheds for 2014 to 2016 (when streamflow data were available for all watersheds) ranged from 17.0 inches (2016) to 25.2 inches (2015). Variations in annual runoff were largely determined by annual precipitation; however, the effects from changes in watershed storage were also evident. Runoff declined during the growing season (April through September) because of high evapotranspiration and declining base flows; runoff increased during the dormant season (October through March) because of replenishment from groundwater that increased base flows and because of higher storm runoff during wetter hydrological conditions. The study watersheds area average runoff ratio, the proportion of precipitation that occurred as stream runoff, was 40.9 percent for the period 2014 to 2016. The base-flow index (BFI) for the study watersheds area averaged 0.43 for the period 2014 to 2016 , indicating that 43 percent of runoff occurred as base flow, and the remainder occurred as stormflow.

The percentage of impervious area in a watershed has a large influence on hydrology as indicated by significant, moderately positive correlations with runoff $(r=0.517)$ and the runoff ratio $(r=0.646)$ and significant, moderate to strong negative correlations with base-flow runoff $(r=-0.637)$ and BFI $(r=-0.898)$. These correlations indicate higher amounts of runoff, lower amounts of base flow, and lower proportions of base-flow runoff with higher percentages of impervious areas. Similar relations have been observed in many other urban studies. Whereas stormwater best management practices (BMPs) have been implemented in the study watersheds, they do not appear to fully mitigate the effects of urban development and land use on stream hydrology.

Seasonal, diurnal, and storm-related variations were observed in the continuously monitored water-quality data. Turbidity was positively related to streamflow. Temperature varied seasonally, diurnally, and with storm runoff. SC exhibited a diurnal pattern and decreased when streamflows were higher, indicating that dissolved constituents were typically more dilute during storms. DO concentrations were highest at midday, likely from plant photosynthesis, and were higher during stormflow, likely because of increased aeration. $\mathrm{pH}$ exhibited seasonal and diurnal variations.

Sample concentrations were compared by watershed and hydrologic condition (base-flow and stormflow). Particulateassociated constituents were typically one or more orders of magnitude higher in stormflow samples than in base-flow samples. Constituents that are predominantly in the dissolved phase were typically more dilute in stormflow samples. Differences in nutrient concentrations between base-flow and stormflow samples varied by constituent and watershed. TN, $\mathrm{NO}_{3}+\mathrm{NO}_{2}$, and storm sample TP concentrations were mostly above their ambient water-quality potential reference conditions, whereas TP concentrations in base-flow samples were near the reference condition for TP. TP concentrations in stormflow samples were frequently high enough to support nuisance levels of algal production in flowing waters. $\mathrm{TCu}$, $\mathrm{TPb}$, and $\mathrm{TZn}$ concentrations in base-flow and stormflow samples exceeded the national recommended aquatic life criteria for chronic and acute conditions, respectively, to varying degrees.

Densities of $E$. coli and fecal coliform were compared by watershed and season. Densities of $E$. coli were frequently above the U.S. Environmental Protection Agency's Beach Action Value (BAV), which indicates unsafe conditions for primary contact recreation, at all sites except Stone Mountain Creek. Sample fecal coliform densities indicate that frequent exceedance of the Georgia bacteria criterion for recreational waters for the May through October season (30-day geometric mean) is likely at most of the sites. The 30-day geometric mean criterion for the November through April season is not likely to be exceeded except at the Snapfinger Creek at Thompson Mill Road, South River, and North Fork Peachtree Creek sites where median sample densities were near or exceeded this criterion.

Predictive regression models for $E$. coli density were developed for each of the 15 monitoring sites to further assess water quality and allow for more timely notification of the potential health risk from elevated levels of fecal bacteria to primary contact recreational users. Results from samples for E. coli density are not available for at least 18 hours because of processing and incubation. Furthermore, bacteria densities can change rapidly during hydrologic events. The models indicated BAV exceedance 100 percent of the time at four sites (South River, Snapfinger Creek at Redan Road, Snapfinger 
Creek at Thompson Mill Road, and Pole Bridge Creek); the lowest exceedance rate was indicated for Cobbs Creek (44.6 percent).

Stream-water loads and yields were estimated for 15 constituents (BOD, COD, TSS, SSC, TN, $\mathrm{NO}_{3}+\mathrm{NO}_{2}$, TP, DP, $\mathrm{TOC}, \mathrm{Ca}, \mathrm{Mg}, \mathrm{TCu}, \mathrm{TPb}, \mathrm{TZn}$, and TDS). A regression-model method was used for constituents that had a moderate to strong concentration-model relation; otherwise, the Beale ratio estimator was used. Regression relations were fit by using multiple linear regression with a forward stepwise approach for model parameter selection using the explanatory variables streamflow, base flow, season, and turbidity. A model residual analysis indicated good model fits. Loads and their uncertainties were estimated by using the USGS LOADEST software. The load estimation methodology was modified by using a time-step approach that accommodated incorporation of storm-composited samples into the concentration-streamflow relations. The methodology was assessed, and cases were noted where biases could result, particularly when the load relations versus streamflow and turbidity were very nonlinear. These biases tend to cancel each other out, but quantification was complex. The use of turbidity in the regression models, a surrogate variable for the density of particulates in suspension, appears to have minimized these biases and improved model estimates.

Constituent loads in the study area were typically higher either in years when runoff was larger or when climate was wetter. Constituents with the largest variations in annual loads included COD, SSC, TSS, and trace metals. Average annual concentrations of SSC, TPb, and TZn were significantly higher for average and wet years than for the dry year (2016), which resulted in larger variations in annual loads between those times. Particulate constituents (TSS, SSC, TN, TP, TCu, TPb, and TZn) and COD had substantially higher uncertainty than constituents that were predominantly dissolved $\left(\mathrm{NO}_{3}+\mathrm{NO}_{2}\right.$, $\mathrm{DP}, \mathrm{Ca}, \mathrm{Mg}$, and TDS), while BOD and TOC loads had an intermediate amount of uncertainty.

Correlations between constituent yields were very strong $(r>0.9)$ between the trace metals, and between BOD and TP, $\mathrm{TP}$ and $\mathrm{TPb}, \mathrm{TP}$ and TDS, and $\mathrm{Ca}$ and TDS. Correlations were also high $(r>0.8)$ for BOD and TP and a majority of the other constituents. Most combinations of $\mathrm{Ca}, \mathrm{Mg}$, TDS, and trace metals also had high correlations. These associations may indicate similar constituent source and transport mechanisms across the study watersheds. The lack of significant correlations with SSC may be due to the presence of higher proportions of sand-sized material in some of the streams that is not reflected in other constituent yields and may indicate additional, differing sources.

The Stone Mountain Creek watershed had among the lowest yields for all 15 constituents. Low particulate yields were likely due to retention of sediment by Stone Mountain Lake and two smaller downstream reservoirs. Reductions in the dissolved portion of nutrient yields were likely due to in-reservoir processes, such as denitrification. The Little Stone
Mountain Creek watershed had some of the lowest yields for BOD, COD, TSS, SSC, TP, DP, TOC, trace metals, and TDS; however, it had the highest $\mathrm{NO}_{3}+\mathrm{NO}_{2}$ yields and the highest portion of $\mathrm{TN}$ as $\mathrm{NO}_{3}+\mathrm{NO}_{2}$. The low yields were likely due to the lack of sources of constituents associated with its predominantly medium-density residential land use ( 95.5 percent), and possible $\mathrm{NO}_{3}+\mathrm{NO}_{2}$ sources were lawn fertilizers and inadequate performance of septic systems. The Intrenchment Creek watershed consistently had some of the highest yields for all constituents except $\mathrm{NO}_{3}+\mathrm{NO}_{2}$. This watershed had a high percentage of impervious area (36.0) and a combination of a high amount of high-density residential (29.9 percent) and com$\mathrm{mercial} /$ industrial/institutional (26.0 percent) land use groups. The upper part of the watershed includes a part of the City of Atlanta and an area with extensive combined sewers. These combined factors may account for the high constituent yields.

The results herein were compared to a similar analysis of 13 urban watersheds in adjacent Gwinnett County. The Gwinnett County study had similar relations of increased BFI and runoff ratios with increased impervious area but had higher BFIs and runoff ratios than DeKalb County for the same percentages of impervious area. This indicates that most of the Gwinnett County watersheds had higher amounts of infiltration and groundwater recharge, resulting in higher proportions of base flow and additional base-flow runoff. The differences in the relations between counties could be the result of differences in watershed characteristics, the time period over which urbanization occurred, and (or) differences in BMP implementation, which have not been assessed in this study. Urbanization occurred later in Gwinnett County, so those watersheds may have had improved BMPs that were designed to decrease storm runoff to allow for additional infiltration.

Mean watershed yields in the DeKalb County study were significantly higher than those in the Gwinnett County study for 6 of the 10 constituents compared (TSS, TP, DP, TOC, $\mathrm{TPb}$, and $\mathrm{TZn}$ ), but the mean yields of the other four constituents (SSC, TN, $\mathrm{NO}_{3}+\mathrm{NO}_{2}$, and TDS) were not significantly different. At the Intrenchment Creek watershed in DeKalb County, yields were substantially higher than the highest watershed yields observed in the Gwinnett County study for TSS, TP, TPb, and TZn. At the Cobbs Creek watershed in DeKalb County, yields were substantially higher than the highest watershed yields observed the Gwinnett County study for TSS and SSC. The high $\mathrm{NO}_{3}+\mathrm{NO}_{2}$ yields at Little Stone Mountain Creek were similar to those at the Yellow River watershed in Gwinnett County; these two watersheds had substantial low-density land use, indicating that they could have similar sources of $\mathrm{NO}_{3}+\mathrm{NO}_{2}$. The Intrenchment Creek watershed in DeKalb County and the North Fork Peachtree Creek at Graves Road watershed in Gwinnett County were similar in that they often had some of the highest constituent yields among their respective study watersheds. These watersheds had high percentages of impervious area and high amounts of heavily developed land use types (commercial/industrial/ institutional and high-density residential) that could explain 
the high constituent yields. Yields from the Stone Mountain Creek watershed were lower than yields at any of the Gwinnett County watersheds, indicating the significant effects of the reservoirs in this watershed on water quality.

The DeKalb County study provides a thorough assessment of watershed characteristics, hydrology, and waterquality status of 15 watersheds. These results can improve the understanding of relations among these various aspects and provide insights into source identification of constituents that can be used by watershed managers to improve the hydrology and water quality of these urban and suburban watersheds. Ongoing monitoring and future assessments could allow for the identification of changes in watershed characteristics and trends in hydrologic metrics and water quality.

\section{References Cited}

Akaike, H., 1974, A new look at the statistical model identification: IEEE Transactions on Automatic Control, v. 19, no. 6, p. 716-723, accessed July 11, 2020, at https://doi.org/ 10.1109/TAC.1974.1100705.

American Public Health Association, 2018a, 2510 Conductivity (2017): Standard methods-For the examination of water and wastewater: American Public Health Association, accessed July 11, 2020, at https://www. standardmethods.org/doi/10.2105/SMWW.2882.027.

American Public Health Association, 2018b, 2540 Solids (2017): Standard methods - For the examination of water and wastewater: American Public Health Association, accessed July 11, 2020, at https://www.standardmethods. org/doi/10.2105/SMWW.2882.030.

American Public Health Association, 2018c, 4500- $\mathrm{H}^{+} \mathrm{pH}$ value (2017): Standard methods-For the examination of water and wastewater: American Public Health Association, accessed July 11, 2020, at https://www.standardmethods. org/doi/10.2105/SMWW.2882.082.

American Public Health Association, 2018d, 5210 Biochemical oxygen demand (BOD): Standard methods - For the examination of water and wastewater: American Public Health Association, accessed July 11, 2020, at https://www.standardmethods.org/doi/10.2105/ SMWW.2882.102.

American Public Health Association, 2018e, 5310 Total organic carbon (TOC) (2017): Standard methods-For the examination of water and wastewater: American Public Health Association, accessed July 11, 2020, at https://www. standardmethods.org/doi/10.2105/SMWW.2882.104.
American Public Health Association, 2018f, 9222 Membrane filter technique for members of the coliform group (2017): Standard methods - For the examination of water and wastewater: American Public Health Association, accessed July 11, 2020, at https://www.standardmethods.org/doi/ 10.2105/SMWW.2882.193.

American Public Health Association, 2018g, 9223 Enzyme substrate coliform test (2017): Standard methods-For the examination of water and wastewater, American Public Health Association, accessed July 11, 2020, at https://www. standardmethods.org/doi/10.2105/SMWW.2882.194.

American Society for Testing and Materials, 2000, Standard test methods for determining sediment concentration in water samples: D3977-97, v. 11.02 Water (II), p. 395-400.

Anderson, C.W., 2005, Turbidity: U.S. Geological Survey Techniques of Water-Resources Investigations, book 9, chap. A6.7, accessed July 11, 2020, at https://doi.org/ 10.3133/twri09A6.7.

Atlanta Regional Commission, 2012, LandPro 2012, accessed July 10, 2018, at https://opendata.atlantaregional.com/ datasets/landpro-2012.

Aulenbach, B.T., 2013, Improving regression-model-based streamwater constituent load estimates derived from serially correlated data: Journal of Hydrology (Amsterdam), v. 503, p. 55-66, accessed July 11, 2020, at https://doi.org/10.1016/ j.jhydrol.2013.09.001.

Aulenbach, B.T., 2019, Data and estimates for wet deposition and streamwater solute fluxes at Panola Mountain Research Watershed, Stockbridge, Ga., water years 1986-2016: U.S. Geological Survey data release, accessed July 11, 2020, at https://doi.org/10.5066/P94JC2PD.

Aulenbach, B.T., 2020, Effects of climate-related variability in storage on streamwater solute concentrations and fluxes in a small forested watershed in the Southeastern United States: Hydrological Processes, v. 34, no. 2, p. 189-208, accessed July 11, 2020, at https://doi.org/10.1002/hyp.13589.

Aulenbach, B.T., Burns, D.A., Shanley, J.B., Yanai, R.D., Bae, K., Wild, A.D., Yang, Y., and Yi, D., 2016, Approaches to stream solute load estimation for solutes with varying dynamics from five diverse small watersheds: Ecosphere, v. 7, no. 6, 22 p., accessed July 11, 2020, at https://doi.org/ 10.1002/ecs2.1298.

Aulenbach, B.T., and Joiner, J.K., 2017, Stream water-quality summary statistics and outliers, streamwater load models and yield estimates, and peak flow modeling parameters for 13 watersheds in Gwinnett County, Georgia: U.S. Geological Survey data release, accessed September 23, 2021, at https://doi.org/10.5066/F7639MXG. 
Aulenbach, B.T., Joiner, J.K., and Painter, J.A., 2017a, Hydrology and water quality in 13 watersheds in Gwinnett County, Georgia, 2001-15: U.S. Geological Survey Scientific Investigations Report 2017-5012, 82 p., accessed July 11, 2020, at https://doi.org/10.3133/sir20175012.

Aulenbach, B.T., Knaak, A.E., and Joiner, J.K., 2021, Streamwater constituent load data, models, and estimates for 15 watersheds in DeKalb County, Georgia, 2012-2016: U.S. Geological Survey data release, https://doi.org/ 10.5066/P9M6WCRH.

Aulenbach, B.T., Landers, M.N., Musser, J.W., and Painter, J.A., 2017b, Effects of impervious area and BMP implementation and design on storm runoff and water quality in eight small watersheds: Journal of the American Water Resources Association, v. 53, no. 2, p. 382-399, accessed July 11, 2020, at https://doi.org/10.1111/1752-1688.12501.

Aulenbach, B.T., and McKee, A.M., 2020, Monitoring and real-time modeling of Escherichia coli bacteria for the Chattahoochee River, Chattahoochee River National Recreation Area, Georgia, 2000-2019: U.S. Geological Survey Open-File Report 2020-1048, 43 p., accessed July 27, 2020, at https://doi.org/10.3133/ofr20201048.

Aulenbach, B.T., and Peters, N.E., 2018, Quantifying climaterelated interactions in shallow and deep storage and evapotranspiration in a forested, seasonally water-limited watershed in the Southeastern United States: Water Resources Research, v. 54, no. 4, p. 3037-3061, accessed July 11, 2020, at https://doi.org/10.1002/2017WR020964.

Beale, E.M.L., 1962, Some uses of computers in operational research: Industrielle Organisation, v. 31, p. 51-52.

Beven, K.J., and Kirkby, M.J., 1979, A physically based, variable contributing area model of basin hydrology / Un modèle à base physique de zone d'appel variable de l'hydrologie du bassin versant: Hydrological Sciences Bulletin, v. 24, no. 1, p. 43-69, accessed August 3, 2020, at https://doi.org/10.1080/02626667909491834.

Bodí, M.B., Martin, D.A., Balfour, V.N., Santín, C., Doerr, S.H., Pereira, P., Cerdà, A., and Mataix-Solera, J., 2014, Wildland fire ash-Production, composition and ecohydro-geomorphic effects: Earth-Science Reviews, v. 130, p. 103-127, accessed June 26, 2020, at https://doi.org/ 10.1016/j.earscirev.2013.12.007.

Bornstein, R., and Lin, Q., 2000, Urban heat islands and summertime convective thunderstorms in Atlanta-Three case studies: Atmospheric Environment, v. 34, no. 3, p. 507-516, accessed July 11, 2020, at https://doi.org/10.1016/S13522310(99)00374-X.
Burkham, D.E., 1985, An approach for appraising the accuracy of suspended-sediment data: U.S. Geological Survey Professional Paper 1333, 18 p., accessed August 5, 2020, at https://doi.org/10.3133/pp1333.

Burnham, K.P., and Anderson, D.R., 2002, Model selection and multimodel inference-A practical informationtheoretic approach (2d. ed.): New York City, New York, Springer-Verlag, $488 \mathrm{p}$.

Cohn, T.A., 1988, Adjusted maximum likelihood estimation of the moments of lognormal populations from type I censored samples: U.S. Geological Survey Open-File Report 88-350, 34 p., accessed July 11, 2020, at https://doi.org/10.3133/ ofr 88350.

Cohn, T.A., Caulder, D.L., Gilroy, E.J., Zynjuk, L.D., and Summers, R.M., 1992, The validity of a simple statistical model for estimating fluvial constituent loads-An empirical study involving nutrient loads entering Chesapeake Bay: Water Resources Research, v. 28, no. 9, p. 2353-2363, accessed July 11, 2020, at https://doi.org/10.1029/ 92WR01008.

Cohn, T.A., DeLong, L.L., Gilroy, E.J., Hirsch, R.M., and Wells, D.K., 1989, Estimating constituent loads: Water Resources Research, v. 25, no. 5, p. 937-942, accessed July 11, 2020, at https://doi.org/10.1029/ WR025i005p00937.

Crawford, C.G., 1991, Estimation of suspended-sediment rating curves and mean suspended-sediment loads: Journal of Hydrology (Amsterdam), v. 129, no. 1-4, p. 331-348, accessed July 11, 2020, at https://doi.org/10.1016/00221694(91)90057-O.

Dann, M.S., Lynch, J.A., and Corbett, E.S., 1986, Comparison of methods for estimating sulfate export from a forested watershed: Journal of Environmental Quality, v. 15, no. 2, p. 140-145, accessed July 11, 2020, at https://doi.org/ 10.2134/jeq1986.00472425001500020011x.

Debbage, N., and Shepherd, J.M., 2018, The influence of urban development patterns on streamflow characteristics in the Charlanta megaregion: Water Resources Research, v. 54, no. 5, p. 3728-3747, accessed July 11, 2020, at https://doi.org/10.1029/2017WR021594.

DeGasperi, C.L., Berge, H.B., Whiting, K.R., Burkey, J.J., Cassin, J.L., and Fuerstenberg, R.R., 2009, Linking hydrologic alteration to biological impairment in urbanizing streams of the Puget Lowland, Washington, USA: Journal of the American Water Resources Association, v. 45, no. 2, p. $512-533$, accessed July 11,2020 , at https://doi.org/ 10.1111/j.1752-1688.2009.00306.x. 
Diem, J.E., Hill, T.C., and Milligan, R.A., 2018, Diverse multi-decadal changes in streamflow within a rapidly urbanizing region: Journal of Hydrology (Amsterdam), v. 556, p. 61-71, accessed July 11, 2020, at https://doi.org/10.1016/ j.jhydrol.2017.10.026.

Dixon, P.G., and Mote, T.L., 2003, Patterns and causes of Atlanta's urban heat island-Initiated precipitation: Journal of Applied Meteorology, v. 42, no. 9, p. 1273-1284, accessed July 11, 2020, at https://doi.org/10.1175/15200450(2003)042<1273:PACOAU>2.0.CO;2.

Dolan, D.M., Yui, A.K., and Geist, R.D., 1981, Evaluation of river load estimation methods for total phosphorus: Journal of Great Lakes Research, v. 7, no. 3, p. 207-214, accessed July 11, 2020, at https://doi.org/10.1016/S03801330(81)72047-1.

Duan, N., 1983, Smearing estimate-A nonparametric retransformation method: Journal of the American Statistical Association, v. 78, no. 383, p. 605-610, accessed April 20, 2020, at https://doi.org/10.2307/2288126.

Earl, S.R., and Blinn, D.W., 2003, Effects of wildfire ash on water chemistry and biota in south-western U.S.A. streams: Freshwater Biology, v. 48, no. 6, p. 1015-1030, accessed June 16, 2020, at https://doi.org/10.1046/j.13652427.2003.01066.x.

Espey, W.H., Morgan, C.W., and Masch, F.D., 1966, Study of some effects of urbanization on storm runoff from a small watershed: Texas Water Development Board Report 23, 110 p., accessed November 1, 2019, at https://repositories.lib. utexas.edu/handle/2152/64863.

Ferguson, R.I., 1986, River loads underestimated by rating curves: Water Resources Research, v. 22, no. 1, p. 74-76, accessed April 20, 2020, at https://doi.org/10.1029/ WR022i001p00074.

Fries, J.S., Characklis, G.W., and Noble, R.T., 2006, Attachment of fecal indicator bacteria to particles in the Neuse River Estuary, North Carolina: Journal of Environmental Engineering, v. 132, no. 10, p. 1338-1345, accessed April 20, 2020, at https://doi.org/10.1061/ (ASCE)0733-9372(2006)132:10(1338).

Gebert, W.A., Rose, W.J., and Garn, H.S., 2012, Evaluation of the effects of Middleton's stormwater-management activities on streamflow and water-quality characteristics of Pheasant Branch, Dane County, Wisconsin 1975-2008: U.S. Geological Survey Scientific Investigations Report 2012-5014, 27 p. plus appendixes, accessed July 11, 2020, at https://doi.org/10.3133/sir20125014.
Goldstein, H., and Healy, M.J.R., 1995, The graphical presentation of a collection of means: Journal of the Royal Statistical Society. Series A, (Statistics in Society), v. 158, no. 1, p. 175-177, accessed July 11, 2020, at https://doi.org/ $10.2307 / 2983411$.

Graf, W.L., 1977, Network characteristics in suburbanizing streams: Water Resources Research, v. 13, no. 2, p. 459-463, accessed July 11, 2020, at https://doi.org/ 10.1029/WR013i002p00459.

Gray, J.R., Glysson, G.D., Turcios, L.M., and Schwarz, G.E., 2000, Comparability of suspended-sediment concentration and total suspended solids data: U.S. Geological Survey Water-Resources Investigations Report 2000-4191, 20 p., accessed July 11, 2020, at https://doi.org/10.3133/ wri004191.

Gregory, M.B., and Calhoun, D.L., 2007, Physical, chemical, and biological responses of streams to increasing watershed urbanization in the Piedmont Ecoregion of Georgia and Alabama, 2003, chap. B of Effects of urbanization on stream ecosystems in six metropolitan areas of the United States: U.S. Geological Survey Scientific Investigations Report 2006-5101-B, 104 p., accessed July 11, 2020, at https://doi.org/10.3133/sir20065101B.

Gregory, M.B., and Frick, E.A., 2000, Fecal-coliform bacteria concentrations in streams of the Chattahoochee River National Recreation Area, Metropolitan Atlanta, Georgia, May-October 1994 and 1995: U.S. Geological Survey Water-Resources Investigations Report 2000-4139, 8 p., accessed April 20, 2020, at https://doi.org/10.3133/ wri20004139.

Helsel, D.R., 1990, Less than obvious-Statistical treatment of data below the detection limit: Environmental Science \& Technology, v. 24, no. 12, p. 1766-1774, accessed August 3, 2020, at https://doi.org/10.1021/es00082a001.

Helsel, D.R., Hirsch, R.M., Ryberg, K.R., Archfield, S.A., and Gilroy, E.J., 2020, Statistical methods in water resources: U.S. Geological Survey Techniques and Methods, book 4, chap. A3, 458 p., accessed March 5, 2021, at https://doi.org/ 10.3133/tm4a3. [Supersedes USGS Techniques of WaterResources Investigations, book 4, chapter A3, version 1.1.]

Hollis, G.E., 1975, The effect of urbanization on floods of different recurrence intervals: Water Resources Research, v. 11, no. 3, p. 431-435, accessed July 11, 2020, at https://doi.org/10.1029/WR011i003p00431. 
Homer, C.G., Dewitz, J.A., Yang, L., Jin, S., Danielson, P., Xian, G., Coulston, J., Herold, N.D., Wickham, J.D., and Megown, K., 2015, Completion of the 2011 National Land Cover Database for the conterminous United StatesRepresenting a decade of land cover change information: Photogrammetric Engineering and Remote Sensing, v. 81, no. 5, p. 345-354, accessed November 22, 2019, at https://cfpub.epa.gov/si/si_public_record_report.cfm?Lab= NERL\&dirEntryId=309950.

Hopkins, K.G., Bhaskar, A.S., Woznicki, S.A., and Fanelli, R.M., 2020, Changes in event-based streamflow magnitude and timing after suburban development with infiltrationbased stormwater management: Hydrological Processes, v. 34, no. 2, p. 387-403, accessed September 28, 2020, at https://doi.org/10.1002/hyp.13593.

Horowitz, A.J., 2003, An evaluation of sediment rating curves for estimating suspended sediment concentrations for subsequent flux calculations: Hydrological Processes, v. 17 , no. 17, p. 3387-3409, accessed July 11, 2020, at https://doi.org/10.1002/hyp.1299.

Horowitz, A.J., 2009, Monitoring suspended sediments and associated chemical constituents in urban environmentsLessons from the City of Atlanta, Georgia, USA Water Quality Monitoring Program: Journal of Soils and Sediments, v. 9, no. 4, p. 342-363, accessed July 11, 2020, at https://doi.org/10.1007/s11368-009-0092-y.

IDEXX Laboratories, Inc., 2002a, Colilert ${ }^{\circledR}-18$ test kit, accessed February 5, 2003, at https:/www.idexx.com/water/ refs/060202711C18.pdf.

IDEXX Laboratories, Inc., 2002b, Quanti-Tray $/ 2000^{\circledR}$, accessed February 5, 2003, at https:/www.idexx.com/water/ refs/0602320.pdf.

Inamdar, S.P., Mostaghimi, S., McClellan, P.W., and Brannan, K.M., 2001, BMP impacts on sediment and nutrient yields from an agricultural watershed in the coastal plain region: Transactions of the ASAE, v. 44, no. 5, p. 1191-1200, accessed July 11, 2020, at https://doi.org/10.13031/ 2013.6449.

Jacobson, C.R., 2011, Identification and quantification of the hydrological impacts of imperviousness in urban catchments - A review: Journal of Environmental Management, v. 92, no. 6, p. 1438-1448, accessed July 11, 2020, at https://doi.org/10.1016/j.jenvman.2011.01.018.

Jastram, J.D., Moyer, D.L., and Hyer, K.E., 2009, A comparison of turbidity-based and streamflow-based estimates of suspended-sediment concentrations in three Chesapeake Bay tributaries: U.S. Geological Survey Scientific Investigations Report 2009-5165, 37 p., accessed October 20, 2020, at https://doi.org/10.3133/sir20095165.
Johnson, A.H., 1979, Estimating solute transport in streams from grab samples: Water Resources Research, v. 15, no. 5, p. 1224-1228, accessed July 11, 2020, at https://doi.org/ 10.1029/WR015i005p01224.

Joiner, J.K., Aulenbach, B.T., and Landers, M.N., 2014, Watershed characteristics and water-quality trends and loads in 12 watersheds in Gwinnett County, Georgia: U.S. Geological Survey Scientific Investigations Report 2014-5141, 79 p., accessed July 11, 2020, at https://doi.org/ $10.3133 / \operatorname{sir} 20145141$.

Journey, C.A., Van Metre, P.C., Waite, I.R., Clark, J.M., Button, D.T., Nakagaki, N., Qi, S.L., Munn, M.D., and Bradley, P.M., 2018, Nutrient enrichment in wadeable urban streams in the Piedmont Ecoregion of the Southeastern United States: Heliyon, v. 4, no. 11, article e00904, 24 p., accessed July 11, 2020, at https://doi.org/10.1016/ j.heliyon.2018.e00904.

Kirchner, J., 2001, Data analysis toolkit \#5-Uncertainty analysis and error propagation: Analysis of Environmental Data Course, University of California, Berkeley, Calif., 8 p., accessed January 17, 2017, at http://seismo.berkeley.edu/ kirchner/eps_120/Toolkits/Toolkit_05.pdf.

Knott, J.M., Glysson, G.D., Malo, B.A., and Schroeder, L.J., 1993, Quality assurance plan for the collection and processing of sediment data by the U.S. Geological Survey, Water Resources Division: U.S. Geological Survey OpenFile Report 92-499, 18 p., accessed July 11, 2020, at https://doi.org/10.3133/ofr92499.

Konrad, C.P., 2003, Effects of urban development on floods: U.S. Geological Survey Fact Sheet 076-03, 4 p., accessed September 28, 2020, at https://doi.org/10.3133/fs07603.

Krometis, L.H., Characklis, G.W., Dilts, M.J., Simmons, O.D., III, Dilts, M.J., Likirdopulos, C.A., and Sobsey, M.D., 2007, Intra-storm variability in microbial partitioning and microbial loading rates: Water Research, v. 41, no. 2, p. 506-516, accessed April 20, 2020, at https://doi.org/10.1016/ j.watres.2006.09.029.

Ku, H.F.H., Hagelin, N.W., and Buxton, H.T., 1992, Effects of urban storm-runoff control on ground-water recharge in Nassau County, New York: Ground Water, v. 30, no. 4, p. 507-514, accessed July 11, 2020, at https://doi.org/ 10.1111/j.1745-6584.1992.tb01526.x.

Lai, S.-H., and Jurinak, J.J., 1972, Cation adsorption in one-dimensional flow through soils - A numerical solution: Water Resources Research, v. 8, no. 1, p. 99-107, accessed July 11, 2020, at https://doi.org/10.1029/ WR008i001p00099. 
Landers, M.N., 2013, Total suspended solids concentrations and yields for water-quality monitoring stations in Gwinnett County, Georgia, 1996-2009: U.S. Geological Survey Open-File Report 2013-1145, 10 p., accessed July 11, 2020, at https://doi.org/10.3133/ofr20131145.

Landers, M.N., Ankcorn, P.D., and McFadden, K.W., 2007, Watershed effects on streamflow quantity and quality in six watersheds of Gwinnett County, Georgia: U.S. Geological Survey Scientific Investigations Report 2007-5132, 62 p., accessed July 11, 2020, at https://doi.org/10.3133/ sir20075132.

Larson, S.J., Capel, P.D., Goolsby, D.A., Zaugg, S.D., and Sandstrom, M.W., 1995, Relations between pesticide use and riverine flux in the Mississippi River basin: Chemosphere, v. 31, no. 5, p. 3305-3321, accessed July 11, 2020, at https://doi.org/10.1016/0045-6535(95)00176-9.

Lawrence, S.J., 2012, Escherichia coli bacteria density in relation to turbidity, streamflow characteristics, and season in the Chattahoochee River near Atlanta, Georgia, October 2000 through September 2008 - Description, statistical analysis, and predictive modeling: U.S. Geological Survey Scientific Investigations Report 2012-5037, 81 p., accessed April 20, 2020, at https://doi.org/10.3133/ sir20125037.

Leopold, L.B., 1968, Hydrology for urban land planning - A guidebook on the hydrologic effects of urban land use: U.S. Geological Survey Circular 554, 18 p., accessed July 11, 2020, at https://doi.org/10.3133/cir554.

Likens, G.E., 2001, Biogeochemistry, the watershed approach-Some uses and limitations: Marine and Freshwater Research, v. 52, no. 1, p. 5-12, accessed July 11, 2020, at https://doi.org/10.1071/MF99188.

Likens, G.E., Bormann, F.H., Pierce, R.S., Eaton, J.S., and Johnson, N.M., 1977, Biogeochemistry of a forested ecosystem: New York, Springer-Verlag, 146 p., accessed July 11, 2020, at https://doi.org/10.1007/978-1-4614-7810-2.

Lim, K.J., Engel, B.A., Tang, Z., Choi, J., Kim, K.-S., Muthukrishnan, S., and Tripathy, D., 2005, Automated Web GIS based Hydrograph Analysis Tool, WHAT: Journal of the American Water Resources Association, v. 41, no. 6, p. 1407-1416, accessed July 11, 2020, at https://doi.org/ 10.1111/j.1752-1688.2005.tb03808.x.

Lim, K.J., Park, Y.S, Kim, J., Shin, Y., Kim, N.W., Kim, S.J., Jeon, J., and Engel, B.A., 2010, Development of genetic algorithm-based optimization module in WHAT system for hydrograph analysis and model application: Computers \& Geosciences, v. 36, no. 7, p. 936-944, accessed October 26, 2021, at https://doi.org/10.1016/j.cageo.2010.01.004.
Liu, Y.B., Gebremeskel, S., De Smedt, F., Hoffmann, L., and Pfister, L., 2006, Predicting storm runoff from different land-use classes using a geographical information systembased distributed model: Hydrological Processes, v. 20, no. 3, p. 533-548, accessed July 11, 2020, at https://doi.org/ 10.1002/hyp.5920.

MacDonald, L.H., 2000, Evaluating and managing cumulative effects - Process and constraints: Environmental Management, v. 26, no. 3, p. 299-315, accessed July 11, 2020, at https://doi.org/10.1007/s002670010088.

Mackey, K.R.M., and Paytan, A., 2009, Phosphorus cycle, in Schaechter, M., ed., Encyclopedia of microbiology (3d ed.): Academic Press, p. 322-334, accessed January 6, 2021, at https://doi.org/10.1016/B978-012373944-5.00056-0.

Maher, K., 2010, The dependence of chemical weathering rates on fluid residence time: Earth and Planetary Science Letters, v. 294, no. 1-2, p. 101-110, accessed July 11, 2020, at https://doi.org/10.1016/j.epsl.2010.03.010.

Maher, K., 2011, The role of fluid residence time and topographic scales in determining chemical fluxes from landscapes: Earth and Planetary Science Letters, v. 312, no. 1-2, p. 48-58, accessed July 11, 2020, at https://doi.org/10.1016/ j.epsl.2011.09.040.

McCrary, M., 2011, Effects of topography on North Georgia (Atlanta, GA), Severe weather and tornadoes, accessed July 12, 2011, at http://www.theweatherprediction.com/ weatherpapers/122/index.html.

McCulloch, C.E., and Neuhaus, J.M., 2012, Misspecifying the shape of a random effects distribution-Why getting it wrong may not matter: Statistical Science, v. 26, no. 3, p. 388-402, accessed April 20, 2020, at https://doi.org/ 10.1214/11-STS361.

Mote, T.L., Lacke, M.C., and Shepherd, J.M., 2007, Radar signatures of the urban effect on precipitation distribution-A case study for Atlanta, Georgia: Geophysical Research Letters, v. 34, L20710, 4 p., accessed July 11, 2020, at https://doi.org/10.1029/2007GL031903.

Mueller, D.K., Schertz, T.L., Martin, J.D., and Sandstrom, M.W., 2015, Design, analysis, and interpretation of field quality-control data for water-sampling projects: U.S. Geological Survey Techniques and Methods, book 4, chap. C4, 54 p., accessed January 4, 2021, at https://dx.doi.org/ $10.3133 / \mathrm{tm} 4 \mathrm{C} 4$.

National Oceanic and Atmospheric Administration, 2018, 1981-2010 U.S. climate normals for Atlanta Dekalb Peachtree Airport, Georgia, United States: National Centers for Environmental Information, accessed February 20, 2018, at https://www.ncdc.noaa.gov/oa/ncdc.html. 
Nodvin, S.C., Driscoll, C.T., and Likens, G.E., 1986, The effect of $\mathrm{pH}$ on sulfate adsorption by a forest soil: Soil Science, v. 142, no. 2, p. 69-75, accessed July 11, 2020, at https://doi.org/10.1097/00010694-198608000-00002.

Ogden, F.L., Pradhan, N.R., Downer, C.W., and Zahner, J.A., 2011, Relative importance of impervious area, drainage density, width function, and subsurface storm drainage on flood runoff from an urbanized catchment: Water Resources Research, v. 47, W12503, 12 p., accessed July 11, 2020, at https://doi.org/10.1029/2011WR010550.

Park, S.W., Mostaghimi, S., Cooke, R.A., and McClellan, P.W., 1994, BMP impacts on watershed runoff, sediment, and nutrient yields: Water Resources Bulletin, v. 30, no. 6, p. 1011-1023, accessed July 11, 2020, at https://doi.org/ 10.1111/j.1752-1688.1994.tb03349.x.

Peters, N.E., 2009, Effects of urbanization on stream water quality in the City of Atlanta, Georgia, USA: Hydrological Processes, v. 23, no. 20, p. 2860-2878, accessed July 11, 2020, at https://doi.org/10.1002/hyp.7373.

Poff, N.L., Allan, J.D., Bain, M.B., Karr, J.R., Prestegaard, K.L., Richter, B.D., Sparks, R.E., and Stromberg, J.C., 1997, The natural flow regime-A paradigm for river conservation and restoration: Bioscience, v. 47, no. 11, p. 769-784, accessed July 11, 2020, at https://doi.org/ $10.2307 / 1313099$.

Porter, A.J., Webber, J.S., Witt, J.W., and Jastram, J.D., 2020, Spatial and temporal patterns in streamflow, water chemistry, and aquatic macroinvertebrates of selected streams in Fairfax County, Virginia, 2007-18: U.S. Geological Survey Scientific Investigations Report 2020-5061, 106 p., accessed October 21, 2020, at https://doi.org/10.3133/ $\operatorname{sir} 20205061$.

Preston, S.D., Bierman, V.J., Jr., and Silliman, S.E., 1989, An evaluation of methods for the estimation of tributary mass loads: Water Resources Research, v. 25, no. 6, p. 1379-1389, accessed July 11, 2020, at https://doi.org/ 10.1029/WR025i006p01379.

Purdue University, 2019, WHAT-Web-based Hydrograph Analysis Tool: West Lafayette, Indiana, accessed June 27, 2019, at https://engineering.purdue.edu/ what/.

Quilbé, R., Rousseau, A.N., Duchemin, M., Poulin, A., Gangbazo, G., and Villeneuve, J.-P., 2006, Selecting a calculation method to estimate sediment and nutrient loads in streams-Application to the Beaurivage River (Québec, Canada): Journal of Hydrology (Amsterdam), v. 326, no. 1-4, p. 295-310, accessed July 11, 2020, at https://doi.org/10.1016/j.jhydrol.2005.11.008.
Rantz, S.E., and others, 1982a, Measurement and computation of streamflow-Volume 1, Measurement of stage and discharge: U.S. Geological Survey Water-Supply Paper 2175, 313 p., accessed July 11, 2020, at https://doi.org/ $10.3133 /$ wsp2175.

Rantz, S.E., and others, 1982b, Measurement and computation of streamflow-Volume 2, Computation of discharge: U.S. Geological Survey Water-Supply Paper 2175, 373 p., accessed July 11, 2020, at https://doi.org/10.3133/wsp2175.

Rasmussen, P.P., Gray, J.R., Glysson, G.D., and Ziegler, A.C., 2009, Guidelines and procedures for computing time-series suspended-sediment concentrations and loads from in-stream turbidity-sensor and streamflow data: U.S. Geological Survey Techniques and Methods, book 3, chap. C4, 52 p., accessed October 20, 2020, at https://doi.org/10.3133/tm3C4.

Richards, K.D., Scudder, B.C., Fitzpatrick, F.A., Steuer, J.J., Bell, A.H., Peppler, M.C., Stewart, J.S., and Harris, M.A., 2010, Effects of urbanization on stream ecosystems along an agriculture-to-urban land-use gradient, Milwaukee to Green Bay, Wisconsin, 2003-2004: U.S. Geological Survey Scientific Investigations Report 2006-5101-E, 210 p., accessed July 11, 2020, at https://doi.org/10.3133/ sir20065101E.

Richter, B.D., Baumgartner, J.V., Braun, D.P., and Powell, J., 1998, A spatial assessment of hydrologic alteration within a river network: Regulated Rivers: Research and Management, v. 14, no. 4, p. 329-340, accessed July 11, 2020, at https://doi.org/10.1002/(SICI)1099-1646(199807/ 08)14:4<329::AID-RRR505>3.0.CO;2-E.

Richter, B.D., Baumgartner, J.V., Powell, J., and Braun, D.P., 1996, A method for assessing hydrologic alteration within ecosystems: Conservation Biology, v. 10, no. 4, p. 1163-1174, accessed July 11, 2020, at https://doi.org/ 10.1046/j.1523-1739.1996.10041163.x.

Reid, R., and Hayes, J., 2003, Mechanisms and control of nutrient uptake in plants: International Review of Cytology, v. 229, p. 73-114, accessed July 11, 2020, at https://doi.org/ 10.1016/S0074-7696(03)29003-3.

Rivett, M.O., Buss, S.R., Morgan, P., Smith, J.W.N., and Bemment, C.D., 2008, Nitrate attenuation in groundwater-A review of biogeochemical controlling processes: Water Resources Research, v. 42, no. 16, p. 4215-4232, accessed July 11, 2020, at https://doi.org/ 10.1016/j.watres.2008.07.020.

Rose, S., and Peters, N.E., 2001, Effects of urbanization on streamflow in the Atlanta area (Georgia, USA) - A comparative hydrological approach: Hydrological Processes, v. 15, no. 8, p. 1441-1457, accessed July 11, 2020, at https://doi.org/10.1002/hyp.218. 
Runkel, R.L., Crawford, C.G., and Cohn, T.A., 2004, Load estimator (LOADEST) - A FORTRAN program for estimating constituent loads in streams and rivers: U.S. Geological Survey Techniques and Methods, book 4, chap. A5, 69 p., accessed July 11, 2020, at https://doi.org/10.3133/tm4A5.

Sanford, W.E., and Selnick, D.L., 2013, Estimation of evapotranspiration across the conterminous United States using a regression with climate and land-cover data: Journal of the American Water Resources Association, v. 49, no. 1, p. 217-230, accessed July 11, 2020, at https://doi.org/ 10.1111/jawr.12010.

SAS Institute Inc., 1989-2018, JMP, ver. 14.3.0: Cary, North Carolina.

Seaburn, G.E., 1969, Effects of urban development on direct run-off to East Meadow Brook, Nassau County, New York: U.S. Geological Survey Professional Paper 627-B, 14 p., accessed July 11, 2020, at https://doi.org/10.3133/pp627B.

Semkin, R.G., Jefferies, D.S., and Clair, T.A., 1994, Hydrochemical methods and relationships for study of stream output from small catchments, chap. 7 of Moldan, B., and Černy, J., eds., Biogeochemistry of small catchments-A tool for environmental research: New York, John Wiley and Sons, p. 163-187, accessed July 11, 2020, at https://www.semanticscholar.org/paper/HydrochemicalMethods-and-Relationships-for-Study-Semkin-Jeffries/ 4afbcf5bda13ac4e80a45f4d04f56d58ad9ce3d7.

Schueler, T., 1994, The importance of imperviousness: Watershed Protection Techniques, v. 1, no. 3, p. 100-111, accessed July 11, 2020, at https://scc.wa.gov/wp-content/ uploads/2015/06/The-Importance-of-Imperviousness_ Schueler_2000.pdf.

Schueler, T.R., Fraley-McNeal, L., and Cappiella, K., 2009, Is impervious cover still important? Review of recent research: Journal of Hydrologic Engineering, v. 14, no. 4, p. 309-315, accessed July 11, 2020, at https://doi.org/ 10.1061/(ASCE)1084-0699(2009)14:4(309).

Schwarz, G.E., 1978, Estimating the dimension of a model: Annals of Statistics, v. 6, no. 2, p. 461-464, accessed April 20, 2020, at https://doi.org/10.1214/aos/1176344136.

Shem, W., and Shepherd, M., 2009, On the impact of urbanization on summertime thunderstorms in Atlanta-Two numerical model case studies: Atmospheric Research, v. 92, no. 2, p. 172-189, accessed July 11, 2020, at https://doi.org/ 10.1016/j.atmosres.2008.09.013.

Shepard, D., 1968, A two-dimensional interpolation function for irregularly-spaced data: ACM '68 - Proceedings of the 1968 23rd ACM national conference, p. 517-524, accessed September 28, 2020, at https://doi.org/10.1145/ 800186.810616 .
Shreve, E.A., and Downs, A.C., 2005, Quality-assurance plan for the analysis of fluvial sediment by the U.S. Geological Survey Kentucky Water Science Center Sediment Laboratory: U.S. Geological Survey Open-File Report 2005-1230, 28 p., accessed July 11, 2020, at https://doi.org/ 10.3133/ofr20051230.

Simmons, D.L., and Reynolds, R.J., 1982, Effects of urbanization on baseflow of selected south-shore streams, Long Island, New York: Water Resources Bulletin, v. 18, no. 5, p. 797-805, accessed July 11, 2020, at https://doi.org/ 10.1111/j.1752-1688.1982.tb00075.x.

Smith, R.A., and Alexander, R.B., 1983, Evidence for acid-precipitation-induced trends in stream chemistry at Hydrologic Bench-Mark stations: U.S. Geological Survey Circular 910, 12 p., accessed July 11, 2020, at https://doi.org/10.3133/cir910.

Smith, R.L., Baumgartner, L.K., Miller, D.N., Repert, D.A., and Böhlke, J.K., 2006, Assessment of nitrification potential in ground water using short term, single-well injection experiments: Microbial Ecology, v. 51, no. 1, p. 22-35, accessed July 11, 2020, at https://doi.org/10.1007/s00248004-0159-7.

Soong, D.T., Murphy, E.A., and Straub, T.D., 2009, Effect of detention basin release rates on flood flows-Application of a model to the Blackberry Creek Watershed in Kane County, Illinois: U.S. Geological Survey Scientific Investigations Report 2009-5106, 33 p., accessed July 11, 2020, at https://doi.org/10.3133/sir20095106.

Soulsby, C., Malcolm, R., Gibbins, C., and Dilks, C., 2001, Seasonality, water quality trends and biological responses in four streams in the Cairngorm Mountains, Scotland: Hydrology and Earth System Sciences, v. 5, no. 3, p. 433-450, accessed October 21, 2020, at https://doi.org/ 10.5194/hess-5-433-2001.

Stephenson, N.L., 1990, Climatic control of vegetation distribution-The role of the water balance: American Naturalist, v. 135, no. 5, p. 649-670, accessed July 11, 2020, at https://doi.org/10.1086/285067.

Stephenson, N.L., 1998, Actual evapotranspiration and deficit—Biologically meaningful correlates of vegetation distribution across spatial scales: Journal of Biogeography, v. 25 , no. 5, p. $855-870$, accessed July 11,2020 , at https://doi.org/10.1046/j.1365-2699.1998.00233.x.

Sterling, J.L., Rosemond, A.D., and Wenger, S.J., 2016, Watershed urbanization affects macroinvertebrate community structure and reduces biomass through similar pathways in Piedmont streams, Georgia, USA: Freshwater Science, v. 35, no. 2, p. 676-688, accessed July 11, 2020, at https://doi.org/10.1086/686614. 
Trimble, S.W., 1997, Contribution of stream channel erosion to sediment yield from an urbanizing watershed: Science, v. 278, no. 5342, p. 1442-1444, accessed July 11, 2020, at https://doi.org/10.1126/science.278.5342.1442.

Turnbull, B.W., and Weiss, L., 1978, A likelihood ratio statistic for testing goodness of fit with randomly censored data:

Biometrics, v. 34, no. 3, p. 367-375, accessed July 11, 2020, at https://doi.org/10.2307/2530599.

U.S. Census Bureau, 2016, American community survey 5-year estimates of 2011-2015 block group data: U.S. Census web page, accessed February 2018 at https://www.census.gov/ geo/maps-data/data/tiger-data.html.

U.S. Drought Monitor, 2020, U.S. drought monitor time series graph for DeKalb County, Georgia: The National Drought Mitigation Center web page, accessed June 22, 2020, at https://droughtmonitor.unl.edu/DmData/Timeseries.aspx.

U.S. Environmental Protection Agency [EPA], 1986, Ambient water quality criteria for dissolved oxygen: Washington, D.C., U.S. Environmental Protection Agency, Office of Water, EPA 440/5-86-003, 46 p., accessed May 11, 2020, at https://nepis.epa.gov/Exe/ZyPDF.cgi?Dockey= 00001MSS.txt.

U.S. Environmental Protection Agency [EPA], 1991, Chemical concentration data near the detection limit: U.S. Environmental Protection Agency, EPA 903-8-91-001, 4 p., accessed August 3, 2020, at https://nepis.epa.gov/Exe/ ZyPURL.cgi?Dockey=9100S9OP.txt.

U.S. Environmental Protection Agency [EPA], 1992, NPDES storm water sampling guidance document: U.S. Environmental Protection Agency, EPA 833-8-92-001, 123 p., accessed November 21, 2019, at https://nepis. epa.gov/Exe/ZyPURL.cgi?Dockey=P1002YY0.txt.

U.S. Environmental Protection Agency [EPA], 1993a, Method 180.1, Determination of turbidity by nephelometry: U.S. Environmental Protection Agency, 10 p., accessed November 21, 2019, at https://www.epa.gov/ sites/production/files/2015-08/documents/method_180-1_ 1993.pdf.

U.S. Environmental Protection Agency [EPA], 1993b, Method 350.1, Revision 2.0 - Determination of ammonia nitrogen by semi-automated colorimetery: U.S. Environmental Protection Agency, 14 p., accessed November 21, 2019, at https://www.epa.gov/sites/production/files/2015-08/ documents/method_350-1_1993.pdf.

U.S. Environmental Protection Agency [EPA], 1993c, Method 351.2, Revision 2.0 - Determination of total Kjeldahl nitrogen by semi-automated colorimetry: U.S. Environmental Protection Agency, 15 p., accessed November 21, 2019, at https://www.epa.gov/sites/production/files/2015-08/ documents/method_351-2_1993.pdf.
U.S. Environmental Protection Agency [EPA], 1993d, Method 353.2, Revision 2.0 - Determination of nitrate-nitrite nitrogen by automated colorimetry: U.S. Environmental Protection Agency, 14 p., accessed July 11, 2020, at https://www.uvm.edu/bwrl/lab_docs/protocols/353.2_ Nitrate_by_cadmium_reduction_(EPA_1993).pdf.

U.S. Environmental Protection Agency [EPA], 1993e, Method 365.1, Revision 2.0-Determination of phosphorus by semi-automated colorimetry: U.S. Environmental Protection Agency, 15 p., accessed November 21, 2019, at https://www.epa.gov/sites/production/files/2015-08/ documents/method_365-1_1993.pdf.

U.S. Environmental Protection Agency [EPA], 1993f, Method 410.4, Revision 2.0 - The determination of chemical oxygen demand by semi-automated colorimetry: U.S. Environmental Protection Agency, 11 p., accessed November 21, 2019, at https://www.epa.gov/sites/production/files/2015-08/ documents/method_410-4_1993.pdf.

U.S. Environmental Protection Agency [EPA], 1994a, Method 200.7, Revision 4.4-Determination of metals and trace elements in waters and wastes by inductively coupled plasma-atomic emission spectrometry: U.S. Environmental Protection Agency, 58 p., accessed November 21, 2019, at https://www.epa.gov/sites/production/files/2015-08/ documents/method_200-7_rev_4-4_1994.pdf.

U.S. Environmental Protection Agency [EPA], 1994b, Method 200.8, Revision 5.4-Determination of trace elements in waters and wastes by inductively coupled plasma-mass spectrometry: U.S. Environmental Protection Agency, 57 p., accessed November 21, 2019, at https://www.epa.gov/sites/ production/files/2015-08/documents/method_200-8_rev_ 5-4_1994.pdf.

U.S. Environmental Protection Agency [EPA], 2000a, Criteria development guidance-Rivers and streams, in U.S. Environmental Protection Agency, Nutrient criteria technical guidance manual-Rivers and streams, EPA-822-B-00-002, accessed June 21, 2012, at https://water.epa.gov/scitech/swguidance/standards/criteria/ nutrients/rivers/index.cfm.

U.S. Environmental Protection Agency [EPA], 2000b, Overview of current total maximum daily load-TMDLProgram and regulations: U.S. Environmental Protection Agency, EPA 841-F-00-009, 4 p., accessed November 22, 2019, at https://nepis.epa.gov/Exe/ZyPURL.cgi?Dockey= P10072PC.txt.

U.S. Environmental Protection Agency [EPA], 2003, Strategy for water quality standards and criteria-Setting priorities to strengthen the foundation for protecting and restoring the Nation's waters: Office of Water (4305T), EPA-823-R-03-010, 48 p., accessed May 12, 2020, at https://www.iwa-network.org/filemanager-uploads/WQ Compendium/Database/Future_analysis/089.pdf. 
U.S. Environmental Protection Agency [EPA], 2012, Recreational Water Quality Criteria: 820-F-12-058, accessed November 4, 2019, at https://www.epa.gov/sites/ production/files/2015-10/documents/rwqc2012.pdf.

U.S. Environmental Protection Agency [EPA], 2015, Rule 391-3-6.03 - Water use classifications and water quality standards [Georgia, 2016]: 53 p., accessed April 20, 2020, at https://www.epa.gov/sites/production/files/2014-12/ documents/gawqs.pdf.

U.S. Environmental Protection Agency [EPA], 2017, Causal Analysis/Diagnosis Decision Information System (CADDIS), volume 2, dissolved oxygen: U.S. Environmental Protection Agency, Office of Research and Development, accessed May 11, 2020, at https:/www.epa.gov/caddisvol2/caddis-volume-2-sources-stressors-responsesdissolved-oxygen.

U.S. Environmental Protection Agency [EPA], 2020, Secondary drinking water standards - Guidance for nuisance chemicals, accessed July 11, 2020, at https://www.epa.gov/sdwa/secondary-drinking-waterstandards-guidance-nuisance-chemicals.

U.S. Geological Survey [USGS], [variously dated], National field manual for the collection of water-quality data: U.S. Geological Survey Techniques of Water-Resources Investigations, book 9, 10 chap. (A0-A10), accessed February 5, 2021, at https://pubs.water.usgs.gov/twri9A.

U.S. Geological Survey [USGS], 2009, Collection, quality assurance, and presentation of precipitation data: Office of Surface Water Technical Memorandum No. 2006.01 (revised December 2009), 29 p., accessed January 6, 2021, at https://water.usgs.gov/admin/memo/SW/OSW_2006-01_ Revised_02122010.pdf.

U.S. Geological Survey [USGS], 2010, Continuous records processing of all water time series data: USGS Water Resources Discipline Policy Memorandum 2010.02, accessed October 26, 2021 at https://water.usgs.gov/waterresources $/$ memos/memo.php?id=3306.

U.S. Geological Survey [USGS], 2011, National Land Cover Database (NLCD) 2011, version 2011: Multi-Resolution Land Characteristics Consortium, accessed March 2, 2018, at https://www.mrlc.gov/data/nlcd-2011-landcover-conus- 0 .

U.S. Geological Survey [USGS], 2013, WaterAlert, accessed January 17, 2017, at https://maps.waterdata.usgs.gov/ mapper/wateralert/.

U.S. Geological Survey [USGS], 2017, 3D Elevation Program (3DEP), accessed December 28, 2017, at https://www. usgs.gov/core-science-systems/ngp/3dep.
U.S. Geological Survey [USGS], 2018, Geologic units by geographic area: U.S. Geological Survey mineral resources online spatial data, accessed February 13, 2018, at https://mrdata.usgs.gov/geology/state/geog-units.html, State $=$ Georgia, County $=$ DeKalb.

U.S. Geological Survey [USGS], 2019, USGS water data for the Nation: U.S. Geological Survey National Water Information System database, accessed June 27, 2019, at https://doi.org/10.5066/F7P55KJN.

U.S. Geological Survey [USGS], 2021a, National Hydrography Dataset, accessed September 23, 2021, at https://www.usgs.gov/core-science-systems/ngp/nationalhydrography/access-national-hydrography-products.

U.S. Geological Survey [USGS], 2021b, Standard Reference Sample Project, accessed March 1, 2021, at https://bqs. usgs.gov/srs/.

U.S. Geological Survey [USGS], 2021c, StreamStatsStreamflow statistics and spatial analysis tools for waterresources applications, accessed January 5, 2021, at https:// streamstats.usgs.gov.

Valocchi, A.J., Street, R.L., and Roberts, P.V., 1981, Transport of ion-exchanging solutes in groundwaterChromatographic theory and field simulation: Water Resources Research, v. 17, no. 5, p. 1517-1527, accessed July 11, 2020, at https://doi.org/10.1029/ WR017i005p01517.

Vogel, J.C., Talma, A.S., and Heaton, T.H.E., 1981, Gaseous nitrogen as evidence for denitrification in groundwater: Journal of Hydrology (Amsterdam), v. 50, p. 191-200, accessed July 11, 2020, at https://doi.org/10.1016/00221694(81)90069-X.

Wagner, R.J., Boulger, R.W., Jr., Oblinger, C.J., and Smith, B.A., 2006, Guidelines and standard procedures for continuous water-quality monitors - Station operation, record computation, and data reporting: U.S. Geological Survey Techniques and Methods, book 1, chap. D3, 51 p., 8 attachments, accessed July 11, 2020, at https://doi.org/ $10.3133 / \mathrm{tm} 1 \mathrm{D} 3$.

Wood, W.W., 1978, Use of laboratory data to predict sulfate sorption during artificial ground-water recharge: Ground Water, v. 16, no. 1, p. 22-31, accessed July 11, 2020, at https://doi.org/10.1111/j.1745-6584.1978.tb03200.x.

Wright, D.B., Smith, J.A., Villarini, G., and Baeck, M.L., 2012, Hydroclimatology of flash flooding in Atlanta: Water Resources Research, v. 48, no. 4, W04524, 14 p., accessed July 11, 2020, at https://doi.org/10.1029/2011WR011371. 


\section{Appendix 1. Water-Quality Assurance and Control Summary}

Water-quality assurance and control measures were implemented to assess data quality and to identify any possible issues with the water-quality sampling methods and laboratory analyses. These measures included the collection and analysis of replicate samples and equipment blanks, and the analysis of laboratory quality control samples.

Replicate sampling is used to assess the combination of variability in sample representativeness, possible sample contamination, and laboratory precision. Results from 21 sample replicate pairs for 19 constituents are summarized in table 1.1. These included 12 storm-composite pairs collected from automatic samplers, 8 pairs of manually collected samples, and 1 pair with mixed sampling approaches. Nineteen sample pairs were collected during storm conditions, and 2 sample pairs were collected during base-flow conditions. The relative percent difference (RPD; table 1.1) was calculated as the absolute difference in concentrations between the sample pair divided by the average concentrations of the sample pair, which was then multiplied by 100 percent. The average RPD is a measure of precision, and the median percent error is a measure of bias. The high average RPDs of total ammonia plus organic nitrogen, dissolved ammonia, and dissolved phosphorus are likely the result of the inclusion of several replicate pairs with concentrations near or below their laboratory reporting limits where precision on a percentage basis is expected to be large. The high average RPD for chemical oxygen demand likely represents the inherent challenge with reproducibility of this analytical method.

Equipment blanks were collected to assess possible contamination during field collection. Blank water was run through manual samplers, and a sample was collected from the Teledyne ISCO automatic sampler with the intake placed in blank water. Results are summarized in table 1.2. Analyte detections occurred but were generally low, indicating minimal evidence of frequent contamination. Average annual concentrations (fig. 29) were generally much higher than the range of detections of blanks such that load estimates were minimally affected by the low levels of contamination. Low amounts of contamination, however, could have affected sample concentrations that were near their laboratory reporting limits (fig. 26).

RTI Laboratories, used in this study, participates in an inter-laboratory round-robin quality-control sample comparison through the USGS Standard Reference Samples Project (USGS, 2021b). The laboratory has participated semiannually between 2014 and 2017 for 7 rounds and 12 constituents (table 1.3). Percent differences were calculated relative to the most probable value for that sample round. The average of

Table 1.1. Summary of replicate comparisons for 19 constituents from 21 paired samples collected in streams in Dekalb County, Georgia.

\begin{tabular}{lccc}
\hline \multicolumn{1}{c}{ Constituent abbreviation } & $\begin{array}{c}\text { Number of replicate } \\
\text { pairs }\end{array}$ & $\begin{array}{c}\text { Number of censored } \\
\text { values }\end{array}$ & $\begin{array}{c}\text { Average relative percent } \\
\text { difference }\end{array}$ \\
\hline Sonde specific conductance & 14 & 0 & 2.1 \\
Biochemical oxygen demand & 17 & 0 & 16.5 \\
COD & 17 & 0 & 54.1 \\
Laboratory pH & 19 & 0 & 1.3 \\
Laboratory turbidity & 10 & 0 & 9.8 \\
Total suspended solids & 19 & 0 & 17.7 \\
Suspended-sediment concentration & 20 & 0 & 9.2 \\
Total nitrate plus nitrite & 19 & 0 & 5.9 \\
Total ammonia plus organic nitrogen & 19 & 1 & 27.6 \\
Dissolved ammonia & 21 & 5 & 38.8 \\
Total phosphorus & 21 & 0 & 31.3 \\
Dissolved phosphorus & 19 & 0 & 29.1 \\
Total organic carbon & 19 & 0 & 4.0 \\
Total calcium & 19 & 0 & 5.2 \\
Total magnesium & 19 & 0 & 6.5 \\
Total copper & 17 & 0 & 6.7 \\
Total lead & 19 & 0 & 7.5 \\
Total zinc & 19 & 0 & 8.0 \\
Total dissolved solids & 19 & 0 & 10.9 \\
\hline
\end{tabular}


Table 1.2. Summary of the stream-water sampling-equipment blank sample results for 22 constituents for the Dekalb County, Georgia, study. Includes number of detections, range of detections, and average contaminant concentration.

[Constituent abbreviations from table 4; na, not applicable; $\mu \mathrm{S} / \mathrm{cm}$, microsiemen per centimeter; ${ }^{\circ} \mathrm{C}$, degrees Celsius; <, less than; mg/L, milligram per liter; FNU, Formazin Nephelometric Units; $\mu \mathrm{g} / \mathrm{L}$, microgram per liter; cfu, colony forming units; E. coli, Escherichia coli; MPN, most probable number; mL, milliliter; C, carbon; N, nitrogen; P, phosphorus; Twenty-two sample blanks were analyzed for bacteria (fecal coliform and E. coli), and 86 sample blanks were analyzed for the other constituents]

\begin{tabular}{llccccc}
\hline \multicolumn{1}{c}{ Constituent abbreviation } & \multicolumn{1}{c}{ Units } & $\begin{array}{c}\text { Number } \\
\text { of } \\
\text { samples }\end{array}$ & $\begin{array}{c}\text { Number of } \\
\text { detections }\end{array}$ & $\begin{array}{c}\text { Range of } \\
\text { detections }\end{array}$ & $\begin{array}{c}\text { Average } \\
\text { contaminant } \\
\text { concentration }\end{array}$ & $\begin{array}{c}\text { Predominant } \\
\text { laboratory } \\
\text { reporting limit }\end{array}$ \\
\hline Sonde specific conductance & $\mu \mathrm{S} / \mathrm{cm}$ at $25^{\circ} \mathrm{C}$ & 83 & 182 & $0-6$ & 1.8 & $<5$ \\
Biochemical oxygen demand & $\mathrm{mg} / \mathrm{L}$ & 83 & 9 & $2-10$ & 4.2 & $<2$ \\
Chemical oxygen demand & $\mathrm{mg} / \mathrm{L}$ & 83 & 28 & $6-45$ & 13.5 & $<4.1$ \\
Laboratory turbidity & $\mathrm{FNU}$ & 84 & 175 & $0.1-5.8$ & 1.4 & $<0.5$ \\
Total suspended solids & $\mathrm{mg} / \mathrm{L}$ & 84 & 15 & $21-3$ & 21.9 & $<2$ \\
Suspended-sediment concentration & $\mathrm{mg} / \mathrm{L}$ & 25 & 20 & $1-14$ & 3.1 & $<1$ \\
Total nitrate plus nitrite & $\mathrm{mg} / \mathrm{L}$ as N & 85 & 13 & $20.001-1.3$ & 20.16 & $<0.01$ \\
Total ammonia plus organic nitrogen & $\mathrm{mg} / \mathrm{L}$ as N & 84 & 45 & $20.08-1.7$ & 20.43 & $<0.18$ \\
Dissolved ammonia & $\mathrm{mg} / \mathrm{L}$ as N & 84 & 22 & $20.01-0.6$ & 20.20 & $<0.2$ \\
Total phosphorus & $\mathrm{mg} / \mathrm{L}$ as $\mathrm{P}$ & 85 & 52 & $0.005-0.035$ & 0.013 & $<0.005$ \\
Dissolved phosphorus & $\mathrm{mg} / \mathrm{L}$ as $\mathrm{P}$ & 84 & 36 & $0.005-0.041$ & 0.010 & $<0.005$ \\
Total organic carbon & $\mathrm{mg} / \mathrm{L}$ as C & 84 & 15 & $20.2-1.7$ & 20.55 & $<2$ \\
Total calcium & $\mathrm{mg} / \mathrm{L}$ & 83 & 3 & $20.1-0.3$ & 20.20 & $<1$ \\
Total magnesium & $\mathrm{mg} / \mathrm{L}$ & 84 & 0 & na & na & $<1$ \\
Total cadmium & $\mu \mathrm{g} / \mathrm{L}$ & 84 & 1 & 20.33 & 20.33 & $<1$ \\
Dissolved cadmium & $\mu \mathrm{g} / \mathrm{L}$ & 83 & 0 & na & na & $<1$ \\
Total copper & $\mu \mathrm{g} / \mathrm{L}$ & 78 & 52 & $0.24-17$ & 1.4 & $<0.2$ \\
Total lead & $\mu \mathrm{g} / \mathrm{L}$ & 84 & 27 & $0.24-15$ & 1.1 & $<0.1$ \\
Total zinc & $\mu \mathrm{g} / \mathrm{L}$ & 79 & 43 & $1.9-88$ & 8.3 & $\mathrm{na}$ \\
Total dissolved solids & $\mathrm{mg} / \mathrm{L}$ & 84 & 36 & $5-40$ & 13.3 & $<5$ \\
Fecal coliform & $\mathrm{cfu} / 100 \mathrm{~mL}$ & 21 & 0 & na & na & $<1$ \\
E. coli & $\mathrm{MPN} / 100 \mathrm{~mL}$ & 22 & 0 & na & na & $<1$ \\
\hline
\end{tabular}

${ }^{1}$ Measurments are typically not reported as censored but are frequently below their laboratory reporting limit.

${ }^{2}$ Minimum uncensored value is less than the predominant laboratory reporting limit.

the absolute value of the percent differences is a measure of the laboratory analytical precision, and the median percent error is a measure of bias. To assess errors unaffected by the larger percent errors that naturally occur near the laboratory reporting limit, analyses where the standard reference most probable value was below the laboratory reporting limit were excluded from this summary $(n=8)$. Median percent errors that are within the range of their average percent differences may be largely the result of analytic imprecision rather than actual bias. 
Table 1.3. Summary of USGS Standard Reference Sample (SRS; USGS, 2021b) Project quality-control samples run by RTI Laboratories used by the DeKalb County, Georgia study.

[RTI Laboratories SRS results are identified by SRS lab number 568. Results are for 12 constituents for the period fall 2014 to fall 2017 (number of sample rounds $=7$ ). The number of laboratories participating varied by sample type and sample round: 17 for major, 5-7 for nutrient (high), and 27-28 for trace sample types.]

\begin{tabular}{|c|c|c|c|c|c|}
\hline Constituent abbreviation & Sample type & $\begin{array}{l}\text { Number of } \\
\text { samples } \\
\text { included }\end{array}$ & $\begin{array}{c}\text { Number } \\
\text { of values } \\
\text { excluded'1 }\end{array}$ & $\begin{array}{c}\text { Average } \\
\text { percent } \\
\text { difference }\end{array}$ & $\begin{array}{c}\text { Median } \\
\text { percent } \\
\text { error }\end{array}$ \\
\hline Laboratory specific conductance & major & 7 & 0 & 4.4 & 0.3 \\
\hline Laboratory $\mathrm{pH}$ & major & 6 & 1 & 4.8 & -4.5 \\
\hline Total nitrate plus nitrite & nutrient (high) & 7 & 0 & 7.7 & -6.8 \\
\hline Total ammonia plus organic nitrogen & nutrient (high) & 3 & 0 & 100.0 & -3.1 \\
\hline Total phosphorus & $\begin{array}{l}\text { major and nutrient } \\
\text { (high) }\end{array}$ & 13 & 1 & 12.6 & -2.2 \\
\hline Total calcium & major & 7 & 0 & 6.2 & -1.3 \\
\hline Total magnesium & major & 7 & 0 & 10.3 & -11.1 \\
\hline Total zinc & trace & 7 & 0 & 5.4 & -1.6 \\
\hline
\end{tabular}

${ }^{1}$ Values were excluded from analysis when the standard reference most probable value was below the laboratory reporting limit and in one case where lab $\mathrm{pH}$ was in obvious error $(=0.98)$. 


\section{Appendix 2. Regression-Model Load Estimation Methodology Changes}

The regression-model load estimation methods used herein are similar to those developed and implemented in Aulenbach and others (2017a) for a similar analysis for Gwinnett County, Georgia. Changes in methodology were made to customize the load estimation approach for the shorter DeKalb County study period and improve load estimation. Changes in methodology are related to (1) how the load computational time step was determined, (2) model parameters included in the default model equation, (3) how loads were estimated when time-step flows exceeded the highest streamflow in the calibration dataset, (4) selection of optimal model parameters, (5) how the streamflow and stormflow threshold criteria were determined, and (6) modifications to the timestep estimation dataset for properly estimating uncertainty in annual loads. Changes for 1, 5 and 6 are documented in the "Regression-model load estimation methods" section of this report. The other changes to the methods are documented in this appendix.

The main change in the model form from Aulenbach and others (2017a) for a similar analysis is the removal of a streamflow-squared term and the time and time-squared trend terms. The streamflow-squared term was omitted because of concern that a polynomial function is more likely to over- or underpredict loads than a linear function when estimating streamflow above the range contained within the calibration dataset. The model fit is unconstrained above this range, and extrapolation employing a polynomial function can result in unrealistic behavior. In Aulenbach and others (2017a), extrapolation was avoided by putting in the average daily streamflow for all time steps for the day if any time steps exceeded the highest streamflow in the calibration dataset. Investigation into the application of this approach for constituents where concentration increased with streamflow indicated that loads had substantial low bias because of the nonlinear relation between load and streamflow for many constituents. For some constituents, the few days of the year with the highest streamflows often represented more than half of the annual load, so this approach is not ideal. Extrapolating the load-streamflow relation well above the highest average time-step streamflow within the calibration dataset can also result in bias. However, extrapolation does not consistently bias the loads higher or lower, which is more desirable than being systematically low when using the daily average streamflow substitution approach.

Aulenbach and others (2017a) used a backward stepwise regression approach manually employed within LOADEST by iteratively removing the term with the highest $p$-value until all remaining terms had $p$-values $<0.05$. Whereas this is a commonly used statistical approach, it is not ideal because a model's significance should be assessed by its overall $p$-value, not the $p$-values of the individual model terms that can be influenced by their relations with each other.

The determination of the stormflow threshold criteria differed from that in Aulenbach and others (2017a), which used the average of the 50th and 75th percentiles of streamflow for a watershed calculated on a day-of-year basis. The determination of the streamflow thresholds was changed to more specifically match when the turbidity stormflow criterion of 20 Formazin Nephelometric Units occurred. The change to a monthly calculation basis of the stream-water thresholds better reflected the overall seasonality than the previously used day-of-year basis, which was more variable because daily streamflow distributions can be quite sensitive to the random occurrence of storms, particularly when the streamflow record contains few years such as in this study. 


\section{Appendix 3. LOADEST Load Model Evaluation}

All LOADEST load models were evaluated to ensure proper model fits and avoid violating modeling assumptions. An example evaluation of model output (fig. 3.1) and plots (fig. 3.2) for the suspended-sediment concentration turbidity model at South Fork Peachtree Creek at Johnson Road are provided. LOADEST model outputs and plots for all LOADEST models are available in Aulenbach and others (2021).

The optimal set of model terms for each load model was determined by using a forward stepwise regression and the corrected Akaike Information Criterion (AICc) prior to employing LOADEST. LOADEST does not contain an automated stepwise regression routine for selecting model parameters but does provide some metrics for evaluating model terms. These include the variance inflation factors (VIF; fig. 3.1A) and significance ( $p$-values) of the model coefficients (fig. $3.1 B$ ). These metrics were not incorporated into the selection of model parameters in this study, however, because using multiple criteria can result in conflicting selection advice. Still, these metrics provide useful information regarding the model parameters selected. The VIF indicates the amount of multicollinearity between model parameters. Model parameters with high VIFs have larger standard errors in estimates of their model coefficients, indicating a less precise fit. Model parameters with values above commonly used criteria of 5 or 10 are typically excluded from the models; however, several model parameters used in equation 2 are expected to have high VIFs when used in combination with each other because indicator variables used to avoid fitting separate models for base-flow and stormflow conditions for streamflow and turbidity variables result in highly correlated streamflow and turbidity parameters. Daily base flow and streamflow parameters are also expected to be highly correlated because of their similar values in base-flow samples. In the example provided (fig. 3.1A), the streamflow and turbidity parameter VIFs exceed the criteria of 5 and are correlated; however, the AICc indicated sufficient improvement in the model to merit including both parameters.

The statistical significance of model parameter coefficients, commonly using a $p$-value $\leq 0.05$ criterion, has also been used to select model parameters (fig. 3.1B). However, this practice is discouraged when more rigorous criteria are available because the coefficient $p$-values are influenced by inclusion of the other model parameters and it is the statistical significance of the overall model that should be assessed. The $p$-values do, however, indicate the relative strength of the model parameters because parameters with lower $p$-values explain a larger portion of the variation in the data. In the example provided (fig. $3.1 B$ ), streamflow and turbidity were more important model parameters in fitting the model than the seasonal terms, and the cosine seasonal term would not be considered significant based on the $p$-value of its coefficient.

The residual variance, regression model $\mathrm{R}^{2}$, and serial correlation of residuals are reported in figure 3.1C. The residual variance reflects the uncertainty in the load estimates, as detailed in the "Load Modeling" section of this report. The regression model $\mathrm{R}^{2}$ indicates the portion of the variation in the data that is explained by the model. The load model $\mathrm{R}^{2}$ can be misleading, however, and is not fully informative because a load model is derived by multiplying a concentration model by streamflow (note that this approach has no effect on the load estimates), thereby inflating the portion of variation explained by the model because of the high correlation between load and streamflow. The strength of a model is better assessed from the concentration-model-adjusted $\mathrm{R}^{2} \mathrm{~s}$ (table 15). The serial correlation of residuals indicates how much correlation is between consecutive samples. High serial correlation can result in load uncertainties being underestimated (Aulenbach, 2013). Model residual serial correlations were generally low, and their magnitudes averaged 0.139; therefore, their effects on model uncertainty estimates were not a concern.

The normality of model residuals was assessed by using the Turnbull-Weiss normality test statistic (fig. 3.1D) and normal quantile plots (fig. 3.2A). In the example, the TurnbullWeiss normality test indicated that residuals could be from a normal distribution, and the closeness of the residuals to the one-to-one line on the normal quantile plot indicates a good fit to the normal distribution. Note that in a normal quantile plot, more variation is expected and acceptable at the two ends of the distribution of points because of the lower frequency of observations. Overall, the Turnbull-Weiss normality test indicated that the residuals of 50 (15.6 percent) of the models are not from a normal distribution. The normal quantile plots of the models where residuals were not normal indicated that the degree of non-normality was low, with residuals distributed in a unimodal fashion and typically with little skew. This means that the residuals are not so non-normal to considerably deviate from the expected normal error distribution and should not have a substantial effect on regression-model parameter estimates (McCulloch and Neuhaus, 2012).

The Grubbs and Beck outlier test criteria were used as a secondary guide for identifying and removing outliers. In the example (fig. $3.1 E$ ), the range of normalized residuals fell within the test criteria, indicating that none of the residuals were identified as outliers. Overall, 23 models (7.2 percent) had one or more values in the calibration dataset that exceeded their test criteria. These outliers were not removed because they were generally within 10 percent of being within the criteria range and did not have a high influence on model fit. The Grubbs and Beck outlier test criteria were reported after outliers were removed, which reduces the variance, resulting in a tendency for additional sample concentrations to be identified as outliers. Hence, iterative use of this criteria can result in excessive removal of good data.

The square root of absolute residuals plotted versus log fitted values is good for checking for heterogeneity (nonuniform) of variance in errors across the range of predicted loads (fig. 3.2B). This plot along with the other residual plots (figs. 3.2C-G) include a solid line to help discern the general 
pattern of data, which is a LOWESS (locally weighted scatterplot smoothing) line fit of the data points. The example in figure $3.2 B$ shows an ideal, relatively uniform level of error across a range of predicted loads, which is the reason for fitting regression models in logarithmic space. For many models, however, errors are substantially better and worse over portions of the range of predictions. If errors are larger for the highest predicted loads, loads are likely to have more uncertainty than indicated by their overall standard error of prediction because these predicted loads account for a larger portion of the total load.

Model residuals plotted versus log fitted values and explanatory variables should ideally be identically distributed above and below zero over the range of the $\mathrm{x}$-variable (figs. 3.2C-G). This does not mean that the density of the cloud of points should be equal over the range of the $\mathrm{x}$-variable, which is a dependent upon the frequency of observed conditions and sampling approach. Model predictions exhibit bias when residuals are consistently above or below zero over portions of the $\mathrm{x}$-variable range, and this is particularly nonideal if this corresponds with conditions when loads are larger. For the example model, some plots exhibit deviations from zero but are not of concern because they are much smaller than overall variability of residuals. Other models exhibited larger deviations, but these deviations were generally not great enough to expect a considerable bias in the load estimates. Other models have residuals that are somewhat heteroscedastic for some variables, indicating that the errors are not uniform across the range of their values. For residual plots versus explanatory variables that incorporate stormflow and base-flow indicator variables (not shown), focusing on the fit of the LOWESS line in the intervening gap in the range of data is not useful because the LOWESS line is not constrained by any data. 


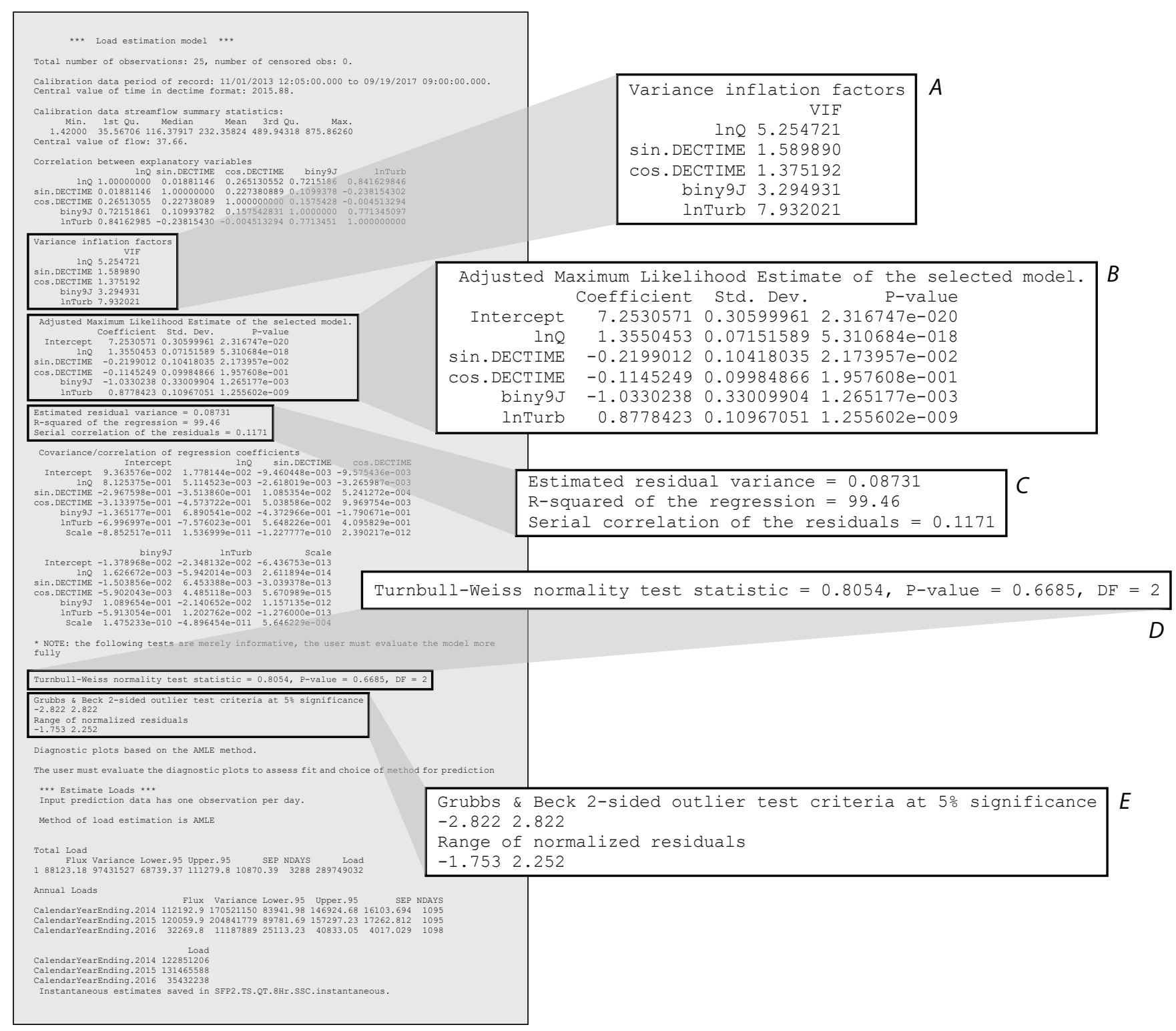

Figure 3.1. Example of LOADEST model output for the suspended-sediment concentration streamflow-turbidity model for the South Fork Peachtree Creek at Johnson Road watershed highlighting model output used to evaluate models: $A$, variance inflation factors, $B, p$-values of model parameter coefficients, $C$, residual variance, regression model R-square, and serial correlation of residuals, $D$, Turnbull-Weiss normality test statistic, and $E$, Grubbs and Beck outlier test criteria. 

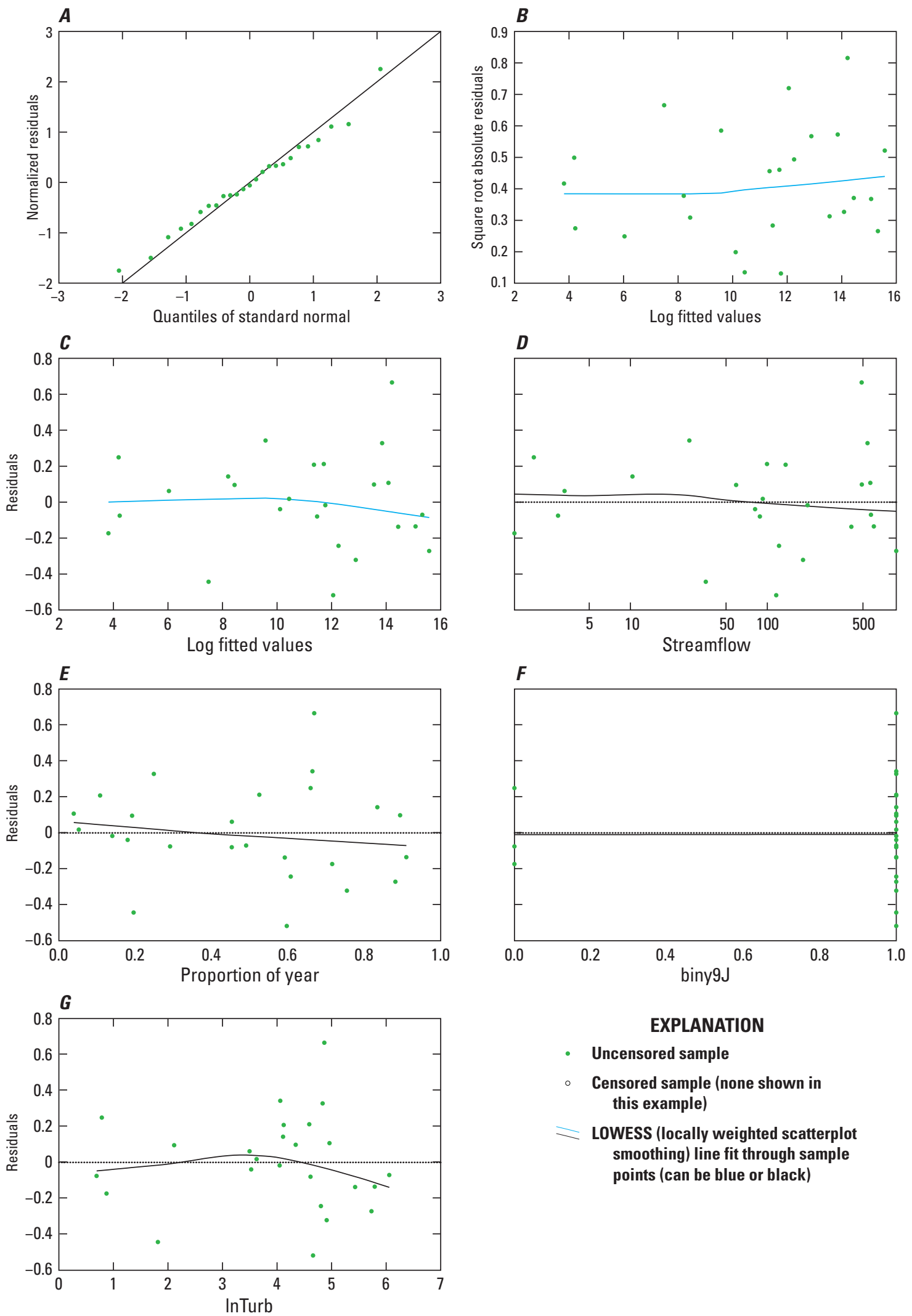

EXPLANATION

- Uncensored sample

- Censored sample (none shown in this example)

LOWESS (locally weighted scatterplot smoothing) line fit through sample points (can be blue or black)

Figure 3.2. Example of LOADEST model evaluation plots for the suspended-sediment concentration streamflow-turbidity model for the South Fork Peachtree Creek at Johnson Road watershed: $A$, normal quantile plot, $B$, square root of absolute residuals versus log fitted values, and residuals versus $C$, log fitted values, $D$, streamflow, $E$, day of year (labeled as "proportion of year" on x-axis), $F$, stormflow indicator variable (labeled as "biny9J" on x-axis), and G, natural log of turbidity (labeled as "InTurb" on x-axis). 


\section{Appendix 4. Assessment of Effects of Time-Step Load Methodology on Load Estimates}

The methodology of estimating loads on a time-step basis - a necessary accommodation to estimate loads from storm-composite samples - can introduce biases in scenarios where storm periods do not conform well with the computational time steps. The problematic scenarios include (1) splitting a storm across two time steps (fig. 4.1B), (2) storm durations that are shorter than the time step (fig. 4.1C), and (3) the splitting of longer storms into multiple time steps (figs. 4.1D and $E$ ). The effects of these scenarios were evaluated by using a range of realistic stormflow dynamics applied over the observed range of streamflow model coefficients. The evaluation was based on streamflow; however, the effects could similarly be determined for turbidity. An important factor affecting the magnitude of biases in all scenarios is the degree of nonlinearity between streamflow and load. The coefficients of the streamflow model parameters ranged from 0.63 to 2.60 (fig. 4.2). Coefficients were low for total nitrate plus nitrite and high for most of the particulate constituents (total suspended solids, suspended-sediment concentrations, total phosphorus, total copper, total lead, and total zinc). Coefficients for chemical oxygen demand, total nitrogen, total calcium, total magnesium, and total dissolved solids were generally near 1.0. A value of 1.0 indicates a linear relation between load and streamflow (models were fit in logarithmic space) such that concentration is not a function of streamflow. Values above and below 1.0 indicate a nonlinear relation. Values above 1.0 indicate increases in concentration with streamflow (enhancement), and values below 1.0 (including negative coefficients) indicate decreases in concentration with streamflow (dilution). Relations are more nonlinear as the model coefficients deviate farther from 1.0. Load biases in all three model scenarios depicted in figure 4.2 are a function of the degree of nonlinearity in the streamflow model. Substantially larger magnitude percent biases occurred at the high end of the observed range. Streamflow coefficients were typically higher for the flow-only models than for the flow-turbidity models. The turbidity coefficient reflecting stormflow conditions was determined from the sum of the coefficients of the turbidity and stormflowturbidity model parameters. The turbidity coefficients range from -0.49 to 1.35 and were typically below 1.0 , indicating a dilution relation with concentration. When evaluating the coefficients for the flow-turbidity models, consider that the streamflow and turbidity variables work together, however, to fit the overall load relation.

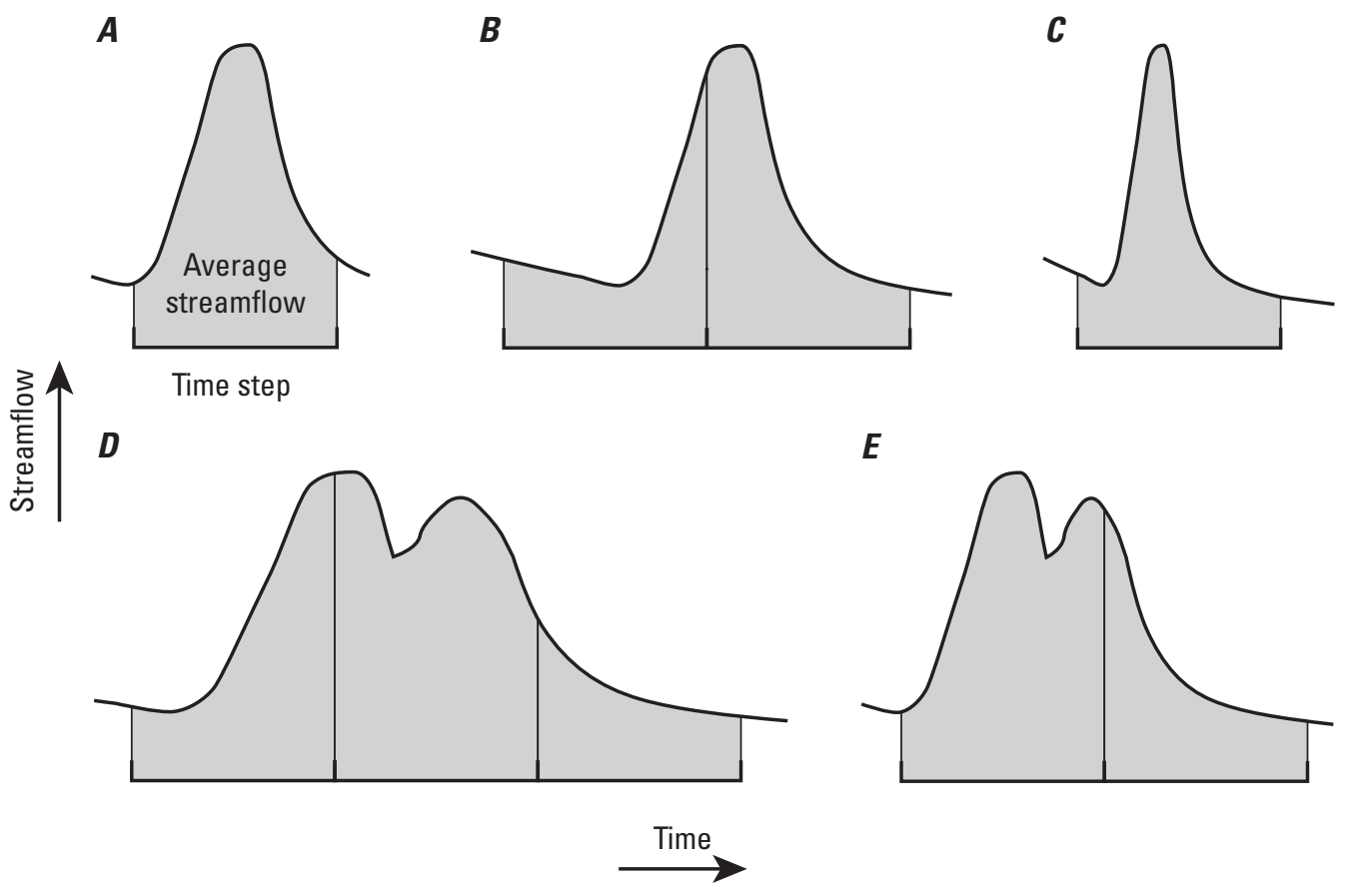

Figure 4.1. Examples of various storm hydrograph scenarios using the time-step load methodology: $A$, idealized storm hydrograph with storm duration equal to time step and storm timing coinciding with time step; $B$, storm hydrograph split across two time steps; $C$, storm hydrograph duration shorter than time step; $D$, storm hydrograph with a duration longer than time step split into multiple time steps; and $E$, storm hydrograph with a duration of about 1.5 times the time step. 

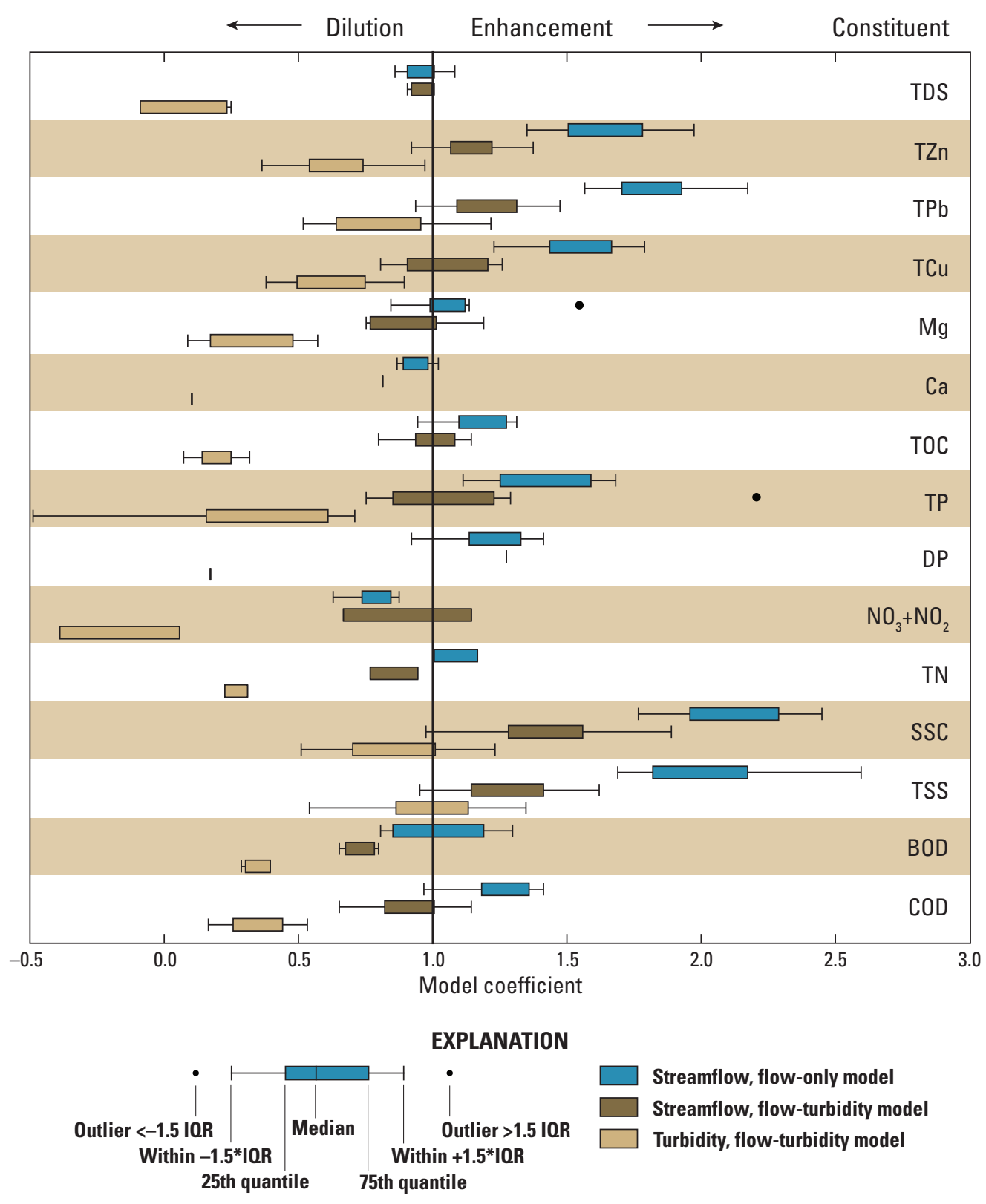

Figure 4.2. Boxplots showing load model coefficients for streamflow and turbidity during stormflow conditions for flow-only and flow-turbidity models by constituent at the 15 monitored watersheds in DeKalb County, Georgia. Turbidity coefficients are the sum of turbidity and stormflow-turbidity coefficients. Ranges indicating dilution and enhancement of concentrations with streamflow are indicated. Abbreviations: TDS, total dissolved solids; TZn, total zinc; TPb, total lead; TCu, total copper; $\mathrm{Mg}$, total magnesium; $\mathrm{Ca}$, total calcium; TOC, total organic carbon; TP, total phosphorus; DP, dissolved phosphorus; $\mathrm{NO}_{3}+\mathrm{NO}_{2}$, total nitrate plus nitrite; $\mathrm{TN}$, total nitrogen; $\mathrm{SSC}$, suspended-sediment concentration; TSS, total suspended solids; BOD, biochemical oxygen demand; COD, chemical oxygen demand; IQR, interquartile range; $>$, greater than; $<$, less than. 
The effect of splitting a storm hydrograph into two computational time steps results in time steps that are an average of base flow and a portion of the storm, both of which have lower average streamflow than what would occur during the storm (fig. 4.1B). Load biases are underestimated when the coefficient is $>1$ (enhancement) and overestimated when the coefficient is $<1$ (dilution). The bias is larger when the storm is split more equally between the two time steps and when there is a larger difference between the percentages of base flow and stormflow.

When the storm hydrograph duration is shorter than the computational time step, the calculation of average streamflow includes a period of base flow such that the time step streamflow is lower than the average storm streamflow (fig. 4.1C). In this situation, loads are underestimated for enhancement and overestimated for dilution, similar to the splitting of the storm hydrograph into two computational time steps (fig. 4.1B). Biases are larger for shorter duration storms and when there is a larger difference between the percentages of base flow and stormflow.

The splitting of storms with long durations into multiple computational time steps typically results in time-step average streamflows which are greater than and less than the average storm streamflow (fig. 4.1D). Loads are generally overestimated for enhancement and underestimated for dilution, in contrast to the two previous scenarios. For a storm duration that is about 1.5 times the time step, however, the effect of splitting the storm across two time steps while incorporating base flow in the averages counteracted this effect (fig. 4.1E). The net effect depended on the various storm attributes, particularly how the storm was split into the two time steps. The amount of bias for longer storms was dependent upon the relative differences in streamflow between the time steps and this was a function of the shape of the storm hydrograph and how it was split into multiple time steps. Storm duration appeared to be only a minor factor because two- and threetime-step storm durations had similar errors for the same hydrograph shape.

Quantifying the overall effects of the three scenarios on loads is difficult because of the multitude of factors, including differences in model relations, the frequency of occurrence of scenarios, and the specifics of storm hydrograph shapes, durations, and time-step divisions. In general, the first two scenarios that applied to smaller storms occurred more frequently and had larger percentage biases, but they represented a smaller portion of the overall load (figs. $4.1 B$ and $C$ ). The third scenario that applied to longer storms occurred less frequently and had relatively smaller percentage biases, but it represented a larger portion of the overall load (fig. 4.1D). These generalities combined with that fact that biases in the first two scenarios are typically in the opposite direction of those in the third scenario indicate that these biases may counteract each other to some degree. It is unlikely that the errors balance each other, however, particularly for model relations that are highly nonlinear; model uncertainties are likely larger than reported when using this time-step methodology. Despite these problematic scenarios, the time-step methodology is expected to be superior to assuming that storm-composite sample average concentrations reflect instantaneous streamflow and applying that instantaneous relation to estimate loads. This "instantaneous" approach is expected to result in much greater biases because of the lack of representativeness of the load-streamflow relation, extrapolation of the relation to much higher instantaneous streamflows, and the substantial nonlinearities in the relations between loads and streamflow observed for some constituents (fig. 4.2).

The use of turbidity in the regression models likely reduces biases resulting from the time-step load estimation methodology. Biases were a function of the degree of nonlinearity, and effects were lower for dilution than for enhancement conditions. In the flow-turbidity models, the combination of the streamflow and turbidity parameters resulted in the coefficients of the streamflow parameters to be lower than in the flow-only model (fig. 4.2) such that the degree of nonlinearity was decreased and, in some cases, changed from enhancement to dilution conditions. The model coefficients for turbidity range from -0.49 to 1.35 , which correspond to smaller time-step approach biases. The availability of turbidity as a surrogate variable can substantially minimize issues with the time-step load estimation methodology.

For more information about this publication, contact

Director, South Atlantic Water Science Center

U.S. Geological Survey

1770 Corporate Drive, Suite 500

Norcross, GA 30093

For additional information, visit

https://www.usgs.gov/centers/sa-water

Publishing support provided by

Lafayette and Reston Publishing Service Centers 



\section{$\frac{2}{2}$}
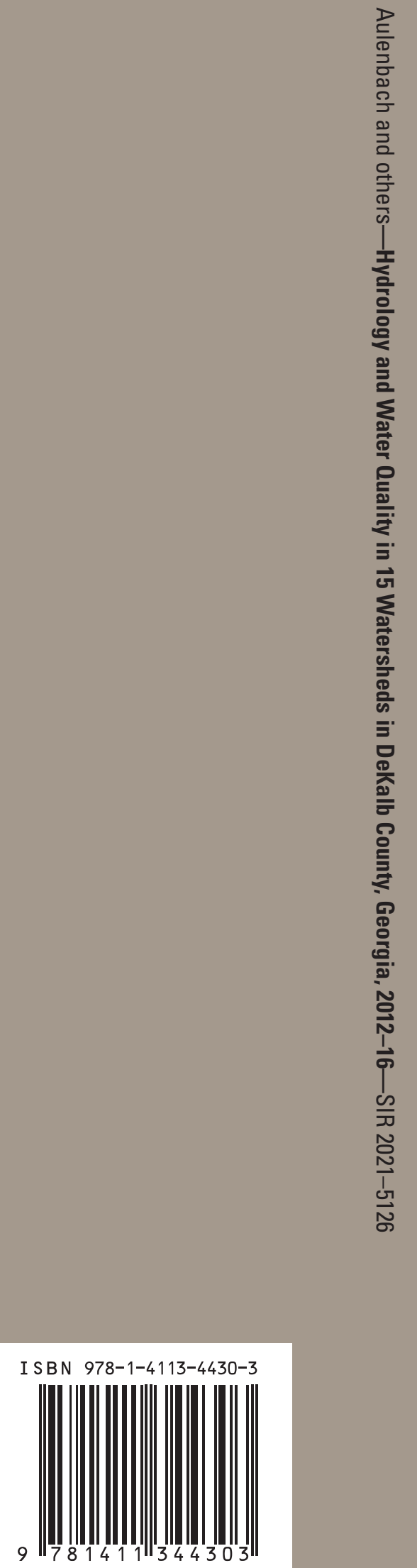